\title{
RYNEK KAPITAłOWY \\ - SZANSE I BARIERY
}





\section{RYNEK KAPITAŁOWY - SZANSE I BARIERY}

REDAKCJA NAUKOWA TERESA CZERWIŃSKA AloJZY Z. NOWAK

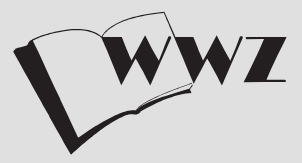

Wydawnictwo Naukowe Wydziału Zarządzania Uniwersytetu Warszawskiego

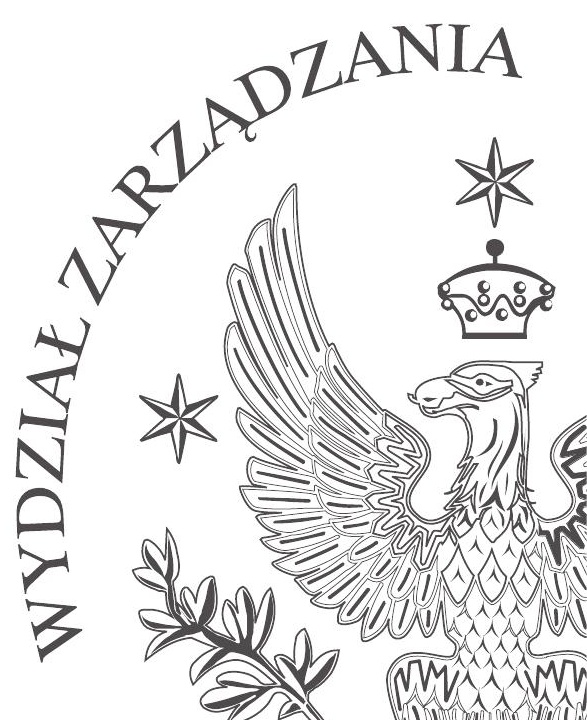


Recenzenci naukowi: dr hab. Teresa Czerwińska, prof. UW prof. dr hab. Andrzej Gospodarowicz prof. dr hab. Marian Górski prof. dr hab. Alojzy Z. Nowak dr Iwona Sroka prof. dr hab. Jan Turyna prof. dr hab. Małgorzata Zaleska

Redakcja: Jerzy Jagodziński Anita Sosnowska

Projekt okładki: Agnieszka Miłaszewicz

(C) Copyright by Wydawnictwo Naukowe Wydziału Zarządzania Uniwersytetu Warszawskiego, Warszawa 2017

ISBN: 978-83-65402-64-6

ISBN: 978-83-65402-65-3 (on line)

DOI: 10.7172/978-83-65402-65-3.2017.wwz.6

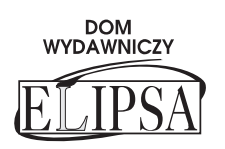




\section{Spis treści}

Wprowadzenie

\section{Rozdzial 1}

Quo vadis europejska unio rynków kapitałowych?

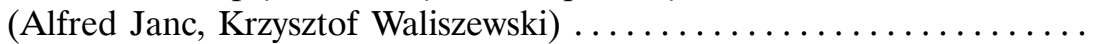

\section{Rozdzial 2}

The Impact of Capital on Lending in Publicly-Traded and Privately-Held Banks in the EU (Małgorzata Olszak, Mateusz Pipień, Iwona Kowalska, Sylwia Roszkowska) .................................

\section{Rozdział 3}

Zarzadzanie $w$ warunkach ryzyka kredytu hipotecznego indeksowanego waluta obca (Jerzy Zemke)

\section{Rozdzial 4}

Inwestorzy indywidualni wobec bezprospektowych publicznych emisji

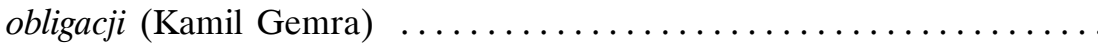

\section{Rozdział 5}

Zmiany stóp zwrotu i plynności akcji spótek po ich ekskluzji z indeksu WIG20 (Tomasz Miziołek) .................................

\section{Rozdzial 6}

Techniki japońskie $w$ warsztacie polskiego inwestora giełdowego.

Czy formacje świecowe moga pomóc przewidzieć zmianę trendu?

(Katarzyna Dąbrowska-Gruszczyńska)

\section{Rozdzial 7}

Koncepcja zastosowania teorii charakteryzacji Gorbatova do budowy modelu wspomagajacego analize portfela akcji spótek gietdowych (Tomasz Prokopowicz, Tadeusz Krupa) 


\section{Rozdzial 8}

Nieetyczne zachowania biur maklerskich jako potencjalna bariera rozwoju rynku kapitatowego w Polsce (Agnieszka Parkitna, Arkadiusz Górski,

Anna Czarnecka) .......................... 135

\section{Rozdzial 9}

The Analysis of the Impact of Capital Mobility on Bubbly Episodes

Creation in the Controlled Laboratory Environment

(Andrii Chlechko) 


\section{Wprowadzenie}

Jedno z zasadniczych pytań, które pojawia się w stosunku do obecnego etapu ekonomiczno-społecznej strategii polskiego rządu dotyczy kwestii sposobów wykorzystania instytucji i instrumentów polskiego rynku kapitałowego do wsparcia rozwoju polskiej gospodarki. Wiąże się to szczególnie z potrzebą zwiększenia poziomu inwestycji w Polsce. Polską gospodarkę wciąż cechuje niska stopa inwestycji, zwłaszcza w sektorze prywatnym. Sektor finansowy w niewystarczającym stopniu finansuje inwestycje przedsiębiorstw, w większym natomiast - konsumpcję osób fizycznych i zakup nieruchomości. Model finansowania przedsiębiorstw w Polsce powinien bardziej opierać się na poszczególnych segmentach rynku kapitałowego. W naszym kraju mamy przykładowo zbyt wolny rozwój rynku dłużnych papierów wartościowych. Tymczasem w krajach wysoko rozwiniętych emisja papierów dłużnych to jedna z trzech głównych form pozyskiwania kapitału przez spółki (obok emisji akcji i zaciągania kredytów inwestycyjnych).

Komisja Europejska również proponuje szybsze rozwijanie inicjatyw na rzecz finansowania firm poprzez różne segmenty rynków kapitałowych. W ramach unii rynków kapitałowych Komisja wyraźnie wskazuje m.in. na zwiększenie roli funduszy inwestycyjnych czy firm ubezpieczeniowych w finansowaniu gospodarki. Zalecenia te są aktualne również dla Polski.

Od roku 2014 w cyklicznych, corocznych monografiach naukowych podejmujemy próbę analizy najważniejszych tendencji zachodzących na rynkach finansowych.

W pierwszej z serii monografii zatytułowanej „Rynek kapitałowy wobec wyzwań dekoniunktury" analizie poddano wybrane zjawiska i tendencje rozwojowe rynku kapitałowego w warunkach kryzysu ogólnogospodarczego. Przedmiotem szczególnych rozważań był zaś paradygmat kreowania i zarządzania wartością (signum temporis współczesnych rynków finansowych). Istotnym segmentem badań autorów publikacji było także modelowanie zjawisk 
na rynku kapitałowym w warunkach niepewności i ryzyka. Jak stwierdzono, znaczny rozwój instrumentów i innowacji finansowych przyczynił się do pewnego rozerwania między rynkiem kapitałowym a realną gospodarką, nasiliło się również zjawisko moral hazard, związane z dynamicznym rozwojem instytucji pośrednictwa finansowego oraz potęgowanie negatywnego wpływu agencji ratingowych.

Druga z cyklu monografii pt.: „Inwestowanie na rynku kapitałowym - rynek po kryzysie", poza wybranymi aspektami funkcjonowania przedsiębiorstw na rynku kapitałowym oraz strategią inwestowania i zarządzania portfelem przez instytucje finansowe, poruszała tematykę zjawiska asymetrii informacji i instrumentarium regulacyjnego, mającego na celu redukcję negatywnych efektów występujących na współczesnym rynku kapitałowym. Jedna z ważnych konkluzji dotycząca poziomu efektywności rynków kapitałowych mówiła, iż w świetle globalizacji i liberalizacji przepływów kapitału niezwykle ważna jest transparentność informacyjna obrotu instrumentami finansowymi. Wciąż aktualna jest potrzeba wypracowania i doskonalenia instrumentarium w zakresie weryfikacji transparentności obrotu, redukcji asymetrii informacyjnej i odpowiedzialności podmiotów funkcjonujących na rynku publicznym.

„Rynek kapitałowy - efektywność i ryzyko" to trzecia publikacja dotykająca problematyki rynku kapitałowego. W dwóch, uzupełniających się częściach autorzy poszczególnych rozdziałów analizowali efektywność informacyjną oraz kwestie strategii i instrumentów tego rynku, wskazywali oni i oceniali m.in. efektywność i ryzyko strategii inwestycyjnych na rynkach kapitałowych. Jednym $\mathrm{z}$ tematów rozważań były potencjalne, niekorzystne skutki niedostatecznie przemyślanej unifikacji rynków kapitałowych w Europie dla polskiego rynku kapitałowego.

Najnowsza, czwarta z kolei publikacja wydana przez Wydawnictwo Naukowe Wydziału Zarządzania Uniwersytetu Warszawskiego jest kontynuacją badań nad rynkiem kapitałowym, zaprezentowanych w trzech poprzednich pracach. Tematyka zamieszczonych artykułów w istotnym stopniu nawiązuje do zawartości tematycznej ostatniej publikacji.

Alfred Janc i Krzysztof Waliszewski w artykule „Quo vadis europejska unio rynków kapitałowych?” nawiązują do wcześniejszych badań nad tym zagadnieniem. Prezentują krytyczną analizę projektu unii rynków kapitałowych w kontekście ostatnich wydarzeń w UE ze wskazaniem potencjalnych zagrożeń dla rynku kapitałowego w Polsce. W artykule zawarto również diagnozę rynku oraz rekomendacje dotyczące kierunków rozwoju rynku kapitałowego w Polsce, których celem ma być zwiększenie roli rynku kapitałowego w finansowaniu gospodarki i sektora MŚP oraz mobilizacja oszczędności długoterminowych. 
Małgorzata Olszak, Mateusz Pipeń, Iwona Kowalska i Sylwia Roszkowska w swoim rozdziale pt.: „The Impact of Capital on Lending in Publicly-Traded and Privately-Held Banks in the EU", opierając się na literaturze przedmiotu, badają wpływ struktury własnościowej na związek między aktywnością kredytową i wskaźnikiem kapitałowym. Jak wynika z teorii, banki notowane na giełdzie są bardziej podatne na uboczne efekty wynikające z relacji agent-pryncypał (pokusa nadużyć i negatywna selekcja) ze względu na rozproszoną strukturę własności. Dlatego też mogą być bardziej podatne na podejmowanie nadmiernego ryzyka w okresie ożywienia, co może skutkować wzrostem procykliczności aktywności kredytowej banków w okresie dekoniunktury. Banki mogą być również bardziej podatne na zaburzenia w funkcjonowaniu mechanizmu rynkowego na rynku kapitałowym. $Z$ zaprezentowanego w treści badania wynika, że związek między aktywnością kredytową i wskaźnikiem kapitałowym jest silniejszy w okresie dekoniunktury w bankach giełdowych niż w bankach, które nie są notowane na giełdzie. Natomiast w okresie dobrej koniunktury, związek ten jest silniejszy w bankach nienotowanych na giełdzie i raportujących nieskonsolidowane sprawozdania finansowe, co jest zgodne z koncepcją, że ograniczony dostęp do rynku kapitałowego prowadzi do wzrostu kosztów zewnętrznego finansowania tych banków. Aktywność kredytowa banków w tej grupie nie jest jednak podatna na ograniczenie związane ze wskaźnikiem kapitałowym w okresie dekoniunktury.

Jerzy Zemke stwierdza z kolei, że zarządzanie ryzykiem kredytów hipotecznych indeksowanych walutą obcą wymaga dostosowań zgodności strumieni odsetek walutowych i złotowych w celu zagwarantowania użycia depozytów złotowych dla zabezpieczenia kredytów w walucie obcej. Problem ten rozwiązywał kontrakt FX SWAP łącznie z transakcją CIRS, gwarantującą refundację różnicy dochodu z tytułu „użyczenia” waluty indeksacji opartej na stawce LIBOR i dochodu z tytułu odsetek od depozytu stanowiącego zabezpieczenie „użyczenia” opartego na stawce WIBOR. Kontrakty FX SWAP i CIRS zapewniały wysoką jakość zabezpieczeń banków przed skutkami ryzyka wzrostu kursu walutowego.

Kamil Gmera w artykule pt. „Inwestorzy indywidualni wobec bezprospektowych publicznych emisji obligacji” identyfikuje różne rodzaje ryzyka związane $\mathrm{z}$ inwestowaniem $\mathrm{w}$ tego typu emisjach obligacji oraz proponuje zmiany, które mogą ograniczyć te rodzaje ryzyka. W artykule przedstawiono też uwarunkowania prawne dotyczące możliwości prowadzenia emisji obligacji w Polsce, jednak kluczową jego część stanowi analiza danych wtórnych dotyczących przeprowadzonych emisji. 
W części monografii poświęconej tematyce inwestycji giełdowych Tomasz Miziołek zwraca uwagę na zmiany stóp zwrotu i płynności akcji spółek po ich ekskluzji z indeksu WIG20. Analiza została przeprowadzona na próbie 23 spółek, których akcje zostały usunięte z ww. indeksu w latach 2007-2016. Wyniki badania dotyczącego stóp zwrotu nie pozwoliły na sformułowanie jednoznacznego wniosku, gdyż po roku od wykluczenia siła relatywna (względem indeksu WIG20) 12 spółek była ujemna, 11 - dodatnia, natomiast indeks siły relatywnej całej grupy zmniejszył się jedynie o 4,3\%. W analizowanym okresie zaobserwowano natomiast istotny spadek płynności (aktywności transakcyjnej), w stosunku do analogicznego okresu przed wykluczeniem z indeksu, w przypadku większości firm.

Katarzyna Dąbrowska-Gruszczyńska w artykule pt. „Techniki japońskie w warsztacie polskiego inwestora giełdowego. Czy formacje świecowe moga pomóc przewidzieć zmianę trendu?" bada skuteczność formacji świec japońskich jako narzędzia przewidującego zmianę trendu. Analizę przeprowadzono na danych dziennych kontraktów terminowych futures na WIG20 w okresie styczeń 2001 - październik 2016. W pierwszej części badania autorka skupiła się na identyfikacji formacji świecowych oraz ich częstotliwości. Drugą część artykułu poświęciła analizie skuteczności zastosowania poszczególnych formacji świecowych w strategiach inwestycyjnych.

Tadeusz Krupa i Tomasz Prokopowicz w artykule „Koncepcja zastosowania teorii charakteryzacji Gorbatova do budowy modelu wspomagającego analizę portfela akcji spółek giełdowych" stwierdzają zaś, że inwestorzy rynku kapitałowego codziennie podejmują decyzje odnośnie do najbardziej optymalnej alokacji swojego kapitału (dającej najwyższy zwrot) w walory spółek notowanych na giełdzie. Każdej z tych decyzji towarzyszy ryzyko związane z niekorzystną (dla inwestora) zmianą kursu cen akcji. Aby je ograniczyć, stosują oni wiele metod wspomagających analizę swojego portfela inwestycyjnego. Autorzy przedstawiają koncepcję zastosowania teorii charakteryzacji Gorbatova do budowy modelu, który mógłby stanowić narzędzie wspierające ocenę portfela akcji notowanych na Warszawskiej Giełdzie Papierów Wartościowych. Koncepcja ta jest pierwszą próbą zastosowania wyżej wymienionej teorii w zagadnieniach związanych z modelowaniem zjawisk na rynku kapitałowym.

Agnieszka Parkitna, Arkadiusz Górski i Anna Czarnecka skupiają się na nieetycznych zachowaniach biur maklerskich. W artykule pt. „Nieetyczne zachowania biur maklerskich jako potencjalna bariera rozwoju rynku kapitałowego w Polsce" wskazują na ten czynnik jako niezwykle ważny dla funkcjonowania polskiej giełdy. Bazą opisanych i przeprowadzonych badań jest istnienie niekorzystnych dla inwestorów zachowań biur maklerskich, które w 
przekonaniu autorów pracy należy uznać za nieetyczne, choć to etyka powinna stanowić podstawę działalności na rynku kapitałowym. Celem artykułu było przeprowadzenie badania transakcji kupna-sprzedaży akcji dokonywanych w imieniu inwestora przez dom maklerski i wskazanie na zachowania podważające zaufanie do rynku kapitałowego, które cechuje nieetyczność oraz wskazanie na konsekwencje, do jakich mogą one doprowadzić. Dodatkowo starano się zaproponować regulacje, które mogłyby przyczynić się do zmniejszenia negatywnych zachowań biur maklerskich, powodujących w konsekwencji odpływ kapitału i negatywne nastawienie drobnych inwestorów do inwestowania na rynku kapitałowym, co w konsekwencji pozytywnie mogłoby wpłynąć na jego rozwój.

Monografię kończy teoretyczny artykuł Andrieja Chlechko pt. „The Analysis of the Impact of Capital Mobility on Bubbly Episodes Creation in the Controlled Laboratory Environment". Autor opracował stylizowany model eksperymentalny, który służy do analizy wpływu wprowadzenia mobilności kapitałowej na zachowanie cen aktywów w kontrolowanym środowisku laboratoryjnym. Ogólna kombinacja prezentowanych czynników pozwala autorowi na analizowanie efektywności rynkowej na podstawie odchylenia ceny rynkowej w stosunku do oczekiwanej średniej wartości aktywów.

\section{***}

Dziękując Autorom za trud poniesiony w przygotowaniu monografii, jak również Recenzentom za wkład w podniesienie wartości merytorycznej, wyrażamy nadzieję, że ta, czwarta z kolei publikacja będzie inspiracją do pogłębionej refleksji naukowej w szeroko zarysowanej tematyce rynku kapitałowego. Mamy też nadzieję, że opinie i badania podjęte nad polskim rynkiem kapitałowym będą służyć praktykom podejmującym decyzje inwestycyjne. Jak już zaznaczyliśmy, na obecnym etapie ekonomiczno-społecznej strategii polskiego rządu warto analizować kwestie sposobów wykorzystania instytucji i instrumentów polskiego rynku kapitałowego do wsparcia rozwoju polskiej gospodarki. Szczególnie wiąże się to z potrzebą zwiększenia poziomu inwestycji w Polsce. Polska gospodarka wciąż cechuje się niską stopą inwestycji, zwłaszcza w sektorze prywatnym. Sektor finansowy w niewystarczającym stopniu finansuje zaś inwestycje przedsiębiorstw, w większym natomiast konsumpcję osób fizycznych i zakup nieruchomości. Model finansowania przedsiębiorstw w Polsce powinien bardziej opierać się na poszczególnych segmentach rynku kapitałowego. 



\title{
Rozdział I
}

\author{
ALFRED JANC ${ }^{*}$, KRZYSZTOF WALISZEWSKI ${ }^{* *}$ \\ Quo vadis \\ europejska unio rynków kapitałowych?
}

Primum non nocere

Referat poświęcony jest krytycznej analizie projektu unii rynków kapitałowych (CMU, Capital Markets Union) w kontekście ostatnich wydarzeń w UE ze wskazaniem potencjalnych zagrożeń dla rynku kapitałowego w Polsce. W artykule zawarto również diagnozę rynku oraz rekomendacje dotyczące kierunków rozwoju rynku kapitałowego w Polsce, których celem ma być zwiększenie roli rynku kapitałowego w finansowaniu gospodarki i sektora MŚP oraz mobilizacja oszczędności długoterminowych.

Słowa kluczowe: unia rynków kapitałowych, rynek kapitałowy w Polsce, finansowanie przedsiębiorstw z sektora MMŚP, oszczędności długoterminowe.

\section{Quo vadis the European Capital Markets Union?}

The paper is devoted to a critical analysis of the capital markets union project (CMU) in the context of recent developments in the $\mathrm{EU}$ with an indication of potential risks to the capital market in Poland. The article also includes a diagnosis of the market and recommendations on the directions of development of the capital market in Poland, whose aim is to increase the role of capital markets in financing the economy and the MSME sector and mobilizing long-term savings.

Keywords: capital markets union, capital market in Poland, SME financing, long-term savings.

JEL: O16, G10, D14, G30

prof. zw. dr hab. Alfred Janc - Katedra Pieniądza i Bankowości, Uniwersytet Ekonomiczny w Poznaniu, Al. Niepodległości 10, 61-875 Poznań; e-mail: poczta@alfredjanc.pl.

** dr hab. Krzysztof Waliszewski, prof. nadzw. UEP - Katedra Pieniądza i Bankowości, Uniwersytet Ekonomiczny w Poznaniu, Al. Niepodległości 10, 61-875 Poznań; e-mail: krzysztof.waliszewski@ue.poznan.pl. 


\section{Wprowadzenie}

Od czasu napisania i opublikowania pierwszej i dotychczas jedynej w Polsce monografii o europejskiej unii rynków kapitałowych, pt. Europejska unia rynków kapitałowych. Perspektywa finansowania przedsiębiorstw w Polsce (CeDeWu, Warszawa 2015), współautorstwa wyżej podpisanych, w obszarze finansowym i gospodarczym UE sporo się zmieniło. Wspomniana monografia - oparta na wiedzy dotyczącej przedmiotu w II połowie ubiegłego roku - traktowała o założeniach, celach, instrumentach i harmonogramie wdrażania projektu, a także jego systemowych podstawach i implikacjach, możliwości zastosowania w polskich realiach gospodarczych oraz szansach i zagrożeniach. Niniejszy rozdział stanowi w pewnym sensie kontynuację rozważań podjętych w monografii, z krytycznym ujęciem części zaproponowanych rozwiązań w tym projekcie oraz uwzględnieniem nowych faktów i opracowań, które w momencie pisania monografii nie były jeszcze znane. W rozdziale autorzy odniosą się również do aktualnej sytuacji na polskim rynku kapitałowym w kontekście zagrożeń, jakie dla naszego rynku stwarza unia rynków kapitałowych.

\section{Unia rynków kapitałowych jako projekt unifikacji rynków kapitałowych w UE - analiza krytyczna}

Kiedy w lutym 2015 r. ogłaszano koncepcję unii rynków kapitałowych (Capital Markets Union, CMU), poprzez opublikowanie Zielonej Księgi (Green Paper), rozpoczęto jednocześnie pierwsze konsultacje w sprawie tego projektu, w wyniku czego zebrano ponad 700 uwag. Podjęto również temat dyrektywy w sprawie prospektu emisyjnego oraz sekurytyzacji wysokiej jakości. W stanowiskach instytucji rynku kapitałowego, rządu i niezależnych gremiów eksperckich formułowano jednoznacznie pozytywną opinię, co do tego przedsięwzięcia, z relatywnie często niemniej jednak artykułowaną obawą dotyczącą ryzyka marginalizacji lokalnych, mniejszych rynków kapitałowych, w tym polskiego rynku kapitałowego. W kolejnych krokach podjęto m.in. plan działań (Action Plan) z tabelą implementacyjną obejmującą 33 działania głównie o charakterze regulacyjnym i terminem realizacji do końca 2018 r.; konsultacje w sprawie kapitału podwyższonego ryzyka (VC/PE); konsultacje w sprawie obligacji zabezpieczonych; konsultacje w sprawie skumulowanych skutków prawodawstwa finansowego, również w zakresie niezamierzonych efektów regulacji. W miarę jednak wchodzenia tych kolejnych etapów w fazę implementacji można było odnotować coraz częstsze wątpliwości oraz głosy krytyczne dotyczące tego projektu. Oczywiście, same cele unii rynków kapitałowych można było wspierać i obejmowały (obejmują) one: dywersyfikację źródeł finanso- 
wania gospodarek europejskich; większe wykorzystywanie finansowania rynkowego przez przedsiębiorstwa z UE; zmniejszenie różnic w obrębie rynków kapitałowych w UE, prowadzące do bardziej swobodnego przepływu kapitału między poszczególnymi krajami i rynkami. W efekcie, inwestorzy mogliby mieć możliwość łatwiejszego lokowania kapitału na rynkach zagranicznych, a emitenci - ułatwione pozyskiwanie tego kapitału transgranicznie. Trudno jednak powstrzymać się od wyrażenia opinii, że w dynamicznie zmieniających się okolicznościach funkcjonowania rynków kapitałowych zaproponowanymi przez unijne organy instrumentami nie da się tych celów osiągnąć.

Warto w tym miejscu wskazać, że między poszczególnymi rynkami kapitałowymi UE występuje dość duże zróżnicowanie w odniesieniu zarówno do kapitalizacji rynku akcji, jak i do wartości instrumentów dłużnych notowanych i nienotowanych na rynku publicznym (wykr. 1).

\section{Wy k r e s 1. Wartość akcji i obligacji w relacji do PKB}

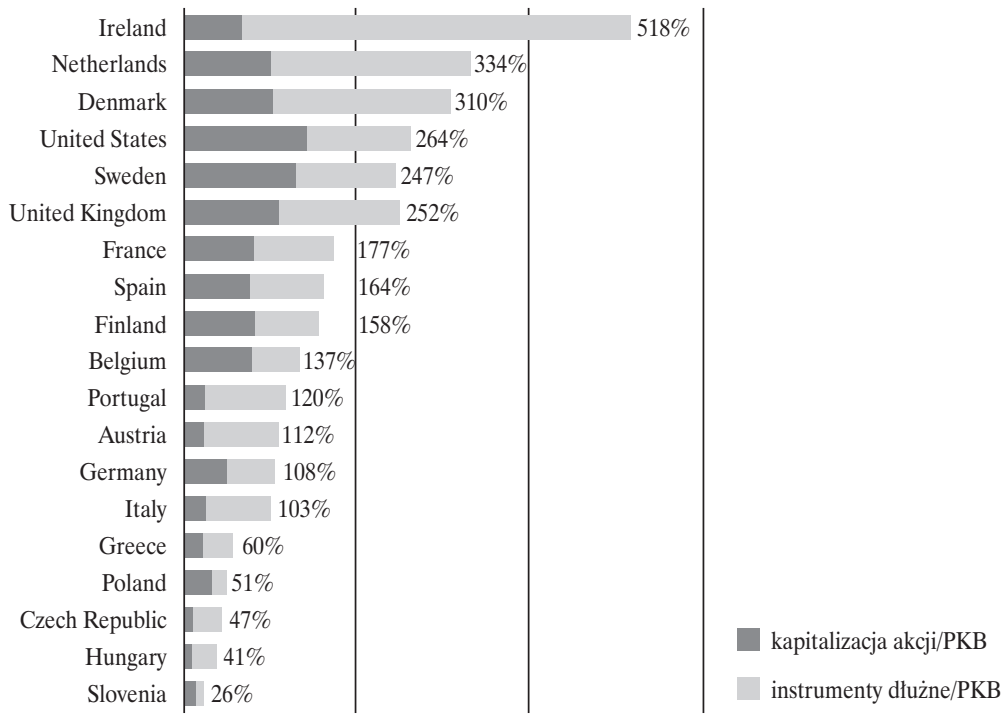

Źródło: GPW, 2015.

Analiza rynków wszystkich 28 państw UE i danych za 2012 r. wykazywała, iż Polska odpowiadała za 1,7\% kapitalizacji notowanych spółek krajowych (178 mld USD) i za $0,8 \%$ obrotów akcjami (67 mld USD). Należeliśmy więc do mniejszych rynków w UE, stanowiąc jednak ważny rynek dla regionu Europy Środkowo-Wschodniej. 
Unia rynków kapitałowych promuje naturalnie rynki największe, najbardziej płynne, najgłębsze i o najniższych kosztach, a przez to najbardziej efektywne, na które zgodnie z założeniami projektu CMU będą się przenosiły spółki obecnie notowane na mniejszych rynkach UE, odpływając z tych rynków i doprowadzając jednocześnie do marginalizacji rynków mniejszych takich przykładowo, jak rynek polski. Rynki największe będą natomiast przyciągać najbardziej atrakcyjnych emitentów i to na tych rynkach dojdzie do koncentracji obrotów. Dotyczy to szczególnie emitentów, którzy poszukują dla swoich emisji inwestorów zagranicznych. Spowoduje to zaniechanie finansowania małych i innowacyjnych firm na rynkach peryferyjnych, konieczność kolejnych regulacji ze strony unijnych urzędników i dalszy odpływ kapitału z polskiego parkietu (Bitner, Bukowski i Siedlecka, 2016). Z kolei, największe rynki kapitałowe, wspierane przez ten projekt, nie będą zainteresowane finansowaniem sektora MŚP na lokalnych rynkach, m.in. ze względu na koszty. W konsekwencji zostanie osiągnięty efekt przeciwny do zamierzonego, jakim miało być wspieranie rozwoju sektora MŚP poprzez ich finansowanie przez rynek kapitałowy. Stworzenie w UE bardziej jednolitego rynku kapitałowego, z mniejszą niż dotychczas ilością różnic prawnych, podatkowych, regulacyjnych, będzie w konsekwencji z wysokim prawdopodobieństwem prowadziło do opisanych wyżej zmian. Inną sprawą jest adresat unii rynków kapitałowych, jakim są firmy z sektora MŚP. Porównawczo, przedsiębiorstwa sektora MŚP w UE to w Polsce przedsiębiorstwa duże i wprowadzenie jednolitej kwoty zwalniającej z obowiązku przygotowania prospektu emisyjnego w Polsce oznaczałoby objęcie większości emisji tym zwolnieniem, co jednocześnie obniżyłoby zaufanie do rynku i emitentów. Istnieje zatem ryzyko ostatecznego przyjęcia rozwiązań nieprzystających do polskich realiów - niezgodnych z zasadą proporcjonalności, a odpowiadających jednakowemu rozwiązaniu dla wszystkich (one size fits all). Konsekwencją różnic w rozwoju gospodarek krajów UE oraz roli krajowych rynków kapitałowych jest trudność w wykreowaniu jednolitego rozwiązania, które byłoby uniwersalne i jednocześnie optymalne dla wszystkich państw i regionów. W tym zakresie konieczne jest najprawdopodobniej zastosowanie dwóch zasad - regionalizacji oraz proporcjonalności, zgodnie z którymi z jednej strony dostrzegane są lokalne rynki kapitałowe i ich rola w rozwoju gospodarczym, a z drugiej zaś - rozwiązania dostosowane zostają do wielkości podmiotów funkcjonujących na tych rynkach.

Dyskusyjne jest również zwiększenie udziału inwestycji transgranicznych $\mathrm{w}$ portfelach inwestorów indywidualnych wobec potwierdzonego $\mathrm{w}$ dobie globalizacji i liberalizacji rynków kapitałowych przez dane statystyczne zjawiska home bias. Polega ono na tendencji inwestorów do nadmiernego inwestowania w krajowe aktywa kosztem inwestycji w akcje spółek zagranicznych (wykr. 2). 


\section{Wy k res 2. Udzial aktywów krajowych w portfelach krajowych inwestorów}

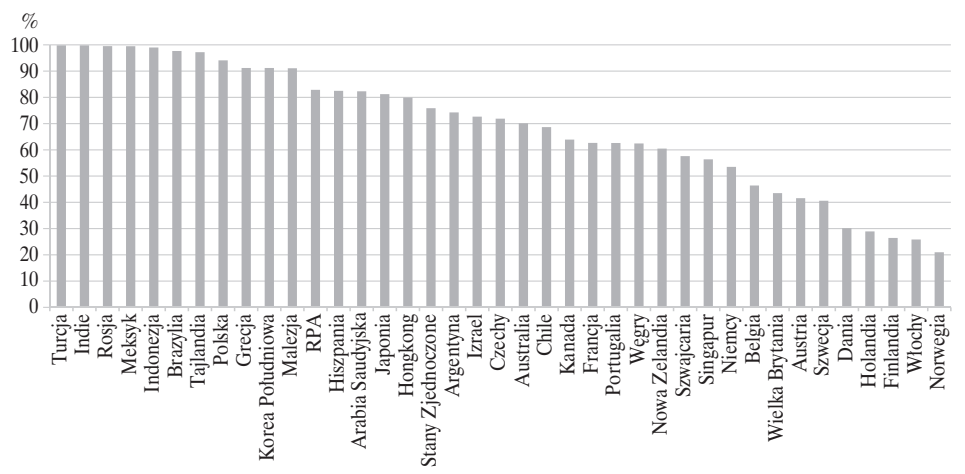

Źródło: Bitner, 2016.

Źródeł tego efektu należy poszukiwać nie tylko w barierach instytucjonalnych, podatkowych czy regulacyjnych, lecz także w czynnikach behawioralnych. Inwestorzy preferują te instrumenty, których emitenci są im znani z rynku krajowego, a wykazują awersję do instrumentów emitowanych przez podmioty zagraniczne, mało im znane. Sytuacja, w której właściciele są fizycznie odlegli od spółki nie jest korzystna. Geografia wpływa bowiem na: dostępność kapitału; płynność walorów spółek; nadzór właścicielski; zachowania menedżerów; funkcjonowanie oddziałów spółek; dostępność funduszy venture capital oraz na trafność ocen analityków.

Można podejrzewać, że pełne umiędzynarodowienie akcjonariatu sprawdza się tylko w przypadku największych globalnych firm. Wyłączywszy tę stosunkowo nieliczną grupę przypadków, za zasadne można uznawać te wyniki badań, które wskazują, że im bliżej są właściciele, tym sprawniej działa spółka, a pozyskiwanie kapitału odbywa się na lepszych warunkach. Przeniesienie się polskich firm na zagraniczne giełdy byłoby więc okupione utratą szeregu korzyści związanych z bliskością macierzystego rynku. W rezultacie dobrodziejstwa płynące z giełdy objęłyby mniejszą liczbę spółek, a korzyści dla tych, którym się udało, byłyby mniejsze. Ewentualne korzyści z harmonizacji są ograniczone ze względu na lokalność rynku kapitałowego, która jest jego immanentną cechą (Directive 2014/65/EU). Zamiast zatem koncentrować się na tworzeniu bardziej zunifikowanych rynków kapitałowych o większej niż dotychczas swobodzie przepływu kapitału poprzez znoszenie barier w jego przepływie, z czego skorzystają największe podmioty na rynku i największe giełdy, warto skierować uwagę na tworzenie warunków do lepszego funkcjonowania lokalnych rynków 
kapitałowych, w tym rynku polskiego. Również po stronie emitentów obserwuje się przywiązanie do danego rynku notowań i nawet jeśli występuje dual listing, i tak pozostają oni na rynku macierzystym.

Dodatkowym źródłem kapitału na rynkach kapitałowych UE zgodnie z projektem CMU mają być środki obecnie lokowane przez większość Europejczyków w bankach. Monodepozytowa struktura oszczędności gospodarstw domowych ma głębokie zakorzenienie systemowe, związane ze zorientowanym bankowo modelem systemu finansowego, gdzie to właśnie tradycyjne banki depozytowo-kredytowe, $\mathrm{z}$ jednej strony są naturalnym miejscem gromadzenia oszczędności gospodarstw domowych, a z drugiej zaś - kredyt bankowy jest głównym źródłem finansowania przedsiębiorstw i gospodarki. Większe zaangażowanie inwestorów indywidualnych na rynkach kapitałowych, jakie obserwuje się w systemach o tzw. modelu anglosaskim, jest związane z większym stopniem akceptacji ryzyka, wykształconą kulturą inwestowania w instrumenty rynku kapitałowego i wyższym poziomem wiedzy ekonomiczno-finansowej. Wątpliwe jest, że w tak krótkim okresie może udać się w Europie zmienić strukturę oszczędności gospodarstw domowych poprzez przesunięcie części depozytów bankowych na rynki i odbudować zaufanie do rynków kapitałowych.

Proponowane przez Komisję Europejską instrumenty mają poza tym na celu pobudzanie aktywności na rynku kapitałowym - emisje publiczne akcji i obligacji, sekurytyzację wysokiej jakości, ożywienie europejskich funduszy inwestycyjnych oraz funduszy podwyższonego ryzyka. Rozwiązania te jednak wydają się rozwiązaniami nieprzystającymi do obecnych praktyk i potrzeb najmniejszych przedsiębiorstw na rynku. Rynek kapitałowy wymaga transparentności i spełniania szeregu obowiązków informacyjnych - prospektowych, okresowych i bieżących, które z jednej strony wiążą się z ponoszeniem dodatkowych kosztów zwiększających finalny koszt finansowania poprzez rynek kapitałowy, a z drugiej - otwierania się na dostęp do informacji o nich dla konkurencji. Ponadto, w przypadku emisji instrumentów udziałowych czy angażowania się kapitałowo w przedsiębiorstwa funduszy inwestycyjnych czy funduszy podwyższonego ryzyka oznacza gotowość do podzielenia się własnością i władzą przez obecnych właścicieli. W opinii autorów referatu, monokultura kredytowa wykształciła w przedsiębiorcach określone przyzwyczajenia co do praw i obowiązków dostawców kapitału bankowego lub pozabankowych dłużnych źródeł finansowania - pożyczek pozabankowych czy emisji papierów dłużnych (obligacji, bonów komercyjnych). Aby przedsiębiorcy byli w większym stopniu niż dotychczas gotowi na dzielenie się władzą, własnością i otwieranie się na dostęp do informacji ze strony konkurencji, sporo czasu musi upłynąć na budowaniu wiedzy i uświadamianiu korzyści, jakie daje przedsiębiorcom 
finansowanie rynkowe. Znacznie więcej czasu, niż przewiduje harmonogram pełnego wdrożenia unii rynków kapitałowych.

Kolejnym dyskusyjnym obszarem, który może utrudniać cele postawione przed unią rynków kapitałowych jest nadmierna ich regulacja. Najnowsze regulacje w tym zakresie - dyrektywa MIFID II (Directive 2014/57/EU), która jest kontynuacją MiFID I i reguluje sposób sprzedaży instrumentów finansowych przez instytucje rynku kapitałowego, dyrektywa MAD (Regulation (EU) No 596/2014) i rozporządzenie MAR (Jóźwik, 2016a) - mają na celu zapobieganie nadużyciom na rynku kapitałowym oraz zapewnienie jego większej przejrzystości. Wprowadzenie jednolitej definicji informacji poufnej, a także rozszerzenie obowiązków w zakresie raportowania transakcji instrumentami finansowymi przez członków władz spółki oraz osoby powiązane z nimi, w połączeniu ze zwiększonymi karami za nierzetelne wypełnianie obowiązków informacyjnych, dostosowane wprawdzie do rynków wysokorozwiniętych, może być dla krajowych firm regulacjami o dotkliwych konsekwencjach (Brunsden, 2016). MAR może być regulacją, która skutecznie będzie odstraszać przedsiębiorstwa od wchodzenia na rynek kapitałowy, a przez to prowadzić do dalszej marginalizacji takiego parkietu, jak warszawski. Zasadne jest zatem pytanie, czy unia rynków kapitałowych jest projektem zwiększającym poziom regulacji, czy ma charakter deregulacyjny, znoszący nadmierne regulacje utrudniające funkcjonowanie instytucji na rynku finansowym i zwiększające koszty ich działalności?

Sytuacja projektu unii rynków kapitałowych zmieniła się po ogłoszeniu wyników referendum przeprowadzonego 23 czerwca 2016 r., w sprawie obecności Wielkiej Brytanii w Unii Europejskiej, w którym większość (51,89\%) opowiedziała się za Brexitem, co oznacza długotrwałe negocjacje odnośnie do warunków wyjścia ze struktur unijnych. Już teraz wiele instytucji finansowych mających swoje siedziby w londyńskim City zapowiada, że ze względu na dużo niewiadomych i ryzyko związane z utratą jednolitego paszportu przeniesie swoje siedziby do innych krajów UE. Brexit może stanowić zatem dla innych europejskich rynków kapitałowych szansę na przyciągnięcie nowych podmiotów. Ze względu na to, że brytyjski rynek kapitałowy jest największy spośród wszystkich rynków UE ${ }^{1}$, wyjście Wielkiej Brytanii może spowodować znaczne zmiany dla projektu. Brexit wywołał również zmiany personalne - 15 lipca 2016 r., w związku z wynikami referendum, rezygnację złożył Brytyjczyk, Jonathan Hill, Komisarz ds. stabilności finansowej, usług finansowych i unii rynków

Udział w kapitalizacji spółek krajowych w UE-28 wynosi blisko $29 \%$, a udział w obrotach z akcjami spółek krajowych UE-28 - blisko 30\%. 
kapitałowych pełniący tę funkcję od listopada 2014 r., czyli początku kadencji nowych władz UE. Jego obowiązki przejął Wiceprzewodniczący Parlamentu Europejskiego nadzorujący funkcjonowanie strefy euro, Valdis Dombrovskis (Łotwa). Może mieć to duże znaczenie z punktu widzenia dostrzegania i uwzględniania interesów krajów o mniejszych rynkach w procesie wdrażania unii rynków kapitałowych. Niemniej jednak, według V. Dombrovskisa, Brexit czyni unię rynków kapitałowych projektem jeszcze bardziej pilnym (State of the Union 2016...), wyrazem czego jest komunikat Komisji Europejskiej o przyspieszeniu prac nad projektem (KE, 2016). Brexit będzie miał poważne konsekwencje dla uczestników rynków, inwestorów, emitentów i gospodarki w Wielkiej Brytanii i reszty UE. Brytyjskie i europejskie rynki kapitałowe są silnie połączone (interconnected) z dominującą rolą Wielkiej Brytanii. Zniesienie tej współzależności może być złożonym, czasochłonnym i kosztownym procesem. Główną zaletą zunifikowanych rynków są korzyści skali, które umożliwiają oferowanie szerszego zakresu usług dla większej liczby klientów przy niższych kosztach. Brexit oznacza zmniejszenie skali rynków kapitałowych UE i wywołuje w początkowym okresie znaczny wzrost niepewności rynków i całej branży, co prowadzi do mniejszej aktywności i inwestycji oraz zmniejszenia skali działalności transgranicznej (Wright, 2016). W dłuższej perspektywie oznacza dywergencję unijnych i brytyjskich regulacji prawnych, dotyczących rynków finansowych.

Jak wskazuje praktyka, europejskie projekty integracyjne w obszarze finansowym - unia bankowa i unia rynków kapitałowych - są bardziej projektami politycznymi niż gospodarczymi. Brakuje zgody co do trzeciego filaru unii bankowej - europejskiego systemu gwarantowania depozytów (EDIS), głównie ze względu na opór Niemiec co do zasad finansowania i uwspólniania (mutualizacji) funduszy gwarancyjnych krajów-uczestników systemu, wskazuje także na polityczny charakter projektów europejskich w obszarze finansowym. Opór Niemiec przed pełnym wdrożeniem unii rynków kapitałowych może być podyktowany obawą o kredytowanie przez banki niemieckie przedsiębiorstw z sektora MŚP, w rezultacie większej roli nadanej finansowaniu rynkowemu.

\section{Aktualna sytuacja rynku kapitałowego w Polsce - czy niezbędna jest nowa strategia rozwoju rynku kapitałowego?}

Dotychczasowe osiągnięcia rynku kapitałowego w Polsce i jego centralnego segmentu, czyli giełdy papierów wartościowych, muszą budzić szacunek. W ciągu 25 lat udało się zbudować od podstaw rynek kapitałowy i giełdę, która aktywnie uczestniczyła $\mathrm{w}$ przemianach gospodarczych w okresie transformacji 
ustrojowej. Jeżeli uwzględnić tylko dane ostatniej dekady, to można zauważyć silny wpływ zaburzeń na rynkach finansowych na polską giełdę (tab. 1). W latach 2004-2015 liczba notowanych spółek uległa podwojeniu z 230 do 487, wzrosła liczba spółek zagranicznych z 5 do 54, co wpłynęło na wzrost ich udziału w strukturze spółek notowanych z 2 do $11 \%$. Liczba ofert publicznych wzrastała dynamicznie w okresie przedkryzysowym z 36 w 2004 r. do 81 w 2007 r., by w kolejnych latach, poza 2009 r., gdy ofert publicznych było tylko 13, oscylować między 20-30. Wartość ofert publicznych była ściśle powiązana z dużymi ofertami spółek Skarbu Państwa prywatyzowanymi przez giełdę.

Ta b e la 1. Liczba spólek notowanych na GPW, ilość i wartość pierwszych ofert publicznych (w mld zl)

\begin{tabular}{|l|r|r|r|r|r|r|r|r|r|r|r|r|}
\hline \multicolumn{1}{|c|}{ Wyszczególnienie } & $\mathbf{2 0 0 4}$ & $\mathbf{2 0 0 5}$ & $\mathbf{2 0 0 6}$ & $\mathbf{2 0 0 7}$ & $\mathbf{2 0 0 8}$ & $\mathbf{2 0 0 9}$ & $\mathbf{2 0 1 0}$ & $\mathbf{2 0 1 1}$ & $\mathbf{2 0 1 2}$ & $\mathbf{2 0 1 3}$ & $\mathbf{2 0 1 4}$ & $\mathbf{2 0 1 5}$ \\
\hline $\begin{array}{l}\text { Liczba spółek } \\
\text { notowanych, w tym: }\end{array}$ & 230 & 255 & 284 & 351 & 374 & 379 & 400 & 426 & 438 & 450 & 471 & 487 \\
\hline \multicolumn{1}{|c|}{ zagranicznych } & 5 & 7 & 12 & 23 & 25 & 25 & 27 & 39 & 43 & 47 & 51 & 54 \\
\hline \multicolumn{1}{|c}{ krajowych } & 225 & 248 & 272 & 328 & 349 & 354 & 373 & 387 & 395 & 403 & 420 & 433 \\
\hline Liczba IPO & 36 & 35 & 38 & 81 & 33 & 13 & 34 & 38 & 19 & 23 & 28 & 30 \\
\hline $\begin{array}{l}\text { Wartość IPO } \\
\text { (w mld zt) }\end{array}$ & 13,2 & 7,0 & 4,2 & 8,0 & 3,9 & 7,0 & 15,9 & 8,5 & 3,4 & 5,1 & 1,3 & 2,0 \\
\hline
\end{tabular}

Źródło: NBP, 2004-2015; www.gpw.pl (26.10.2016).

Wy k r e s 3. Kapitalizacja giełdy i spółek krajowych (w mld zł) oraz kapitalizacja spółek krajowych/PKB (w \%)

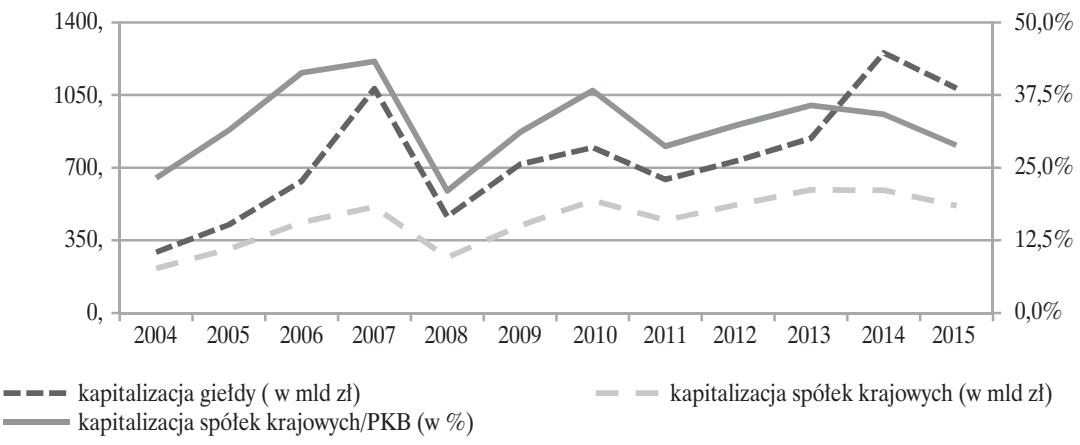

Źródło: NBP, 2004-2015; www.gpw.pl (26.10.2016).

W zakresie kapitalizacji GPW można zauważyć okres silnego jej wzrostu do 2007 r. do ponad 1 bln zł, a następnie silnego spadku w 2008 r. w związku z konsekwencjami kryzysu finansowego (2007-2009), a w kolejnych latach - odbudo- 
wywanie tego wskaźnika do 2014 r., gdy osiągnął maksymalną wartość ponad 1,2 bln zł. W roku 2015 wskaźnik obniżył się do 1,082 bln zł. Podobne tendencje można zaobserwować w przypadku kapitalizacji spółek krajowych z wartościami granicznymi blisko 510 mld zł w 2007 r., ponad 260 mld zł w 2008 r., około 590 mld zł w latach 2013 i 2014 oraz ponad 516 mld zł w 2015 r. (wykr. 3).

Kształtowanie się stopy zwrotu z indeksu WIG potwierdza również silny jego związek z koniunkturą gospodarczą. Szczególnie w ostatnich czterech latach zauważalna jest tendencja spadkowa tej stopy zwrotu do wartości blisko $-10 \%$ w 2015 r. (wykr. 4).

Wy k res 4. Stopa zwrotu $z$ indeksu WIG (w \%)

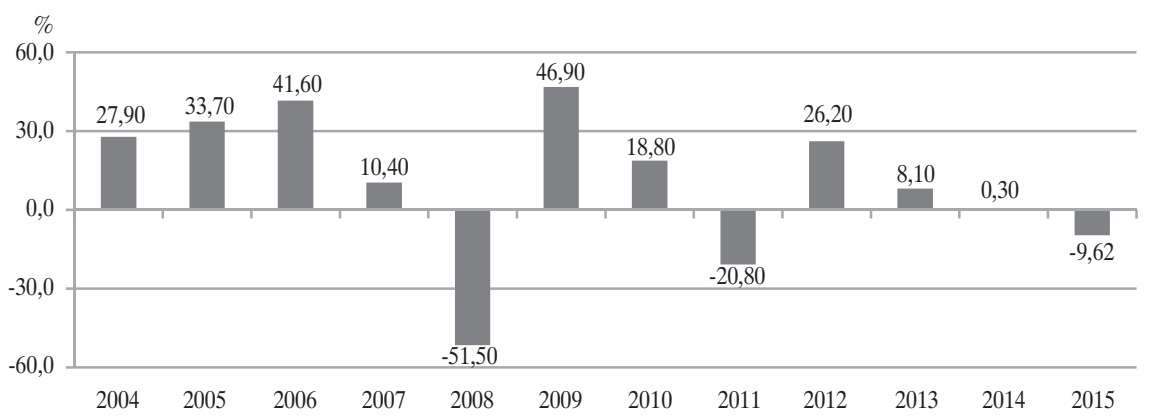

Źródło: NBP, 2004-2015; www.gpw.pl (26.10.2016).

$\mathrm{Z}$ danych rynku giełdowego $\mathrm{z}$ ostatnich kilku lat rysuje się nie najlepszy obraz polskiego rynku kapitałowego. Szczególnie dotyczy to koniunktury giełdowej i stóp zwrotu z inwestycji w instrumenty tego rynku. W 2009 r. indeks WIG, obrazujący koniunkturę na szerokim rynku akcji, potrafił zyskać 46 proc., ale dynamika odbicia wynikała przede wszystkim ze skali wcześniejszego spadku. Po relatywnie dobrych latach 2012-2013, także w 2014 i 2015 r. inwestorzy częściej liczyli straty, niż cieszyli się zyskami. Efekt jest taki, że w czasie, kiedy na rynku amerykańskim czy niemieckim indeksy regularnie biły w ostatnich latach rekordy, WIG w dalszym ciągu znajduje się 30 proc. poniżej historycznego szczytu z 2007 r. (Jóźwik, 2016).

$\mathrm{Na}$ dodatek, reforma emerytalna z 2014 r. i wprowadzenie tzw. suwaka bezpieczeństwa oznacza, że otwarte fundusze emerytalne, które dotąd były ważnym inwestorem instytucjonalnym będą częściej sprzedawać niż kupować akcje, generując dodatkową ich podaż (Jóźwik, 2016b). To również ma negatywny wpływ na aktualną sytuację na rynku. Warszawska giełda, która przez 
ostatnie dekady rosła na ofertach publicznych prywatyzowanych spółek Skarbu Państwa, wobec braku takich ofert w przyszłości w obserwowanej historycznie skali musi poszukiwać nowych możliwości rozwoju. Należy jednak podkreślić, że osiągnięciem warszawskiej giełdy jest to, że przeprowadza się na niej emisje akcji i pozyskuje się realny kapitał - wg danych za 2016 r. GPW zajmowała pod tym względem 3 miejsce w Europie (IPO Watch Europe, 2016).

Konieczne są działania, które na poziome lokalnym będą skutecznie przyciągały na warszawski parkiet emitentów i inwestorów. Warszawa od lat była centrum kapitałowym dla regionu Europy Środkowo-Wschodniej i nadal rolę takiego centrum powinna odgrywać, ponieważ nadal posiada najwyższą kapitalizację do PKB w regionie (wykr. 5).

\section{Wykres 5. Kapitalizacja rynku akcji/PKB (w \%)}

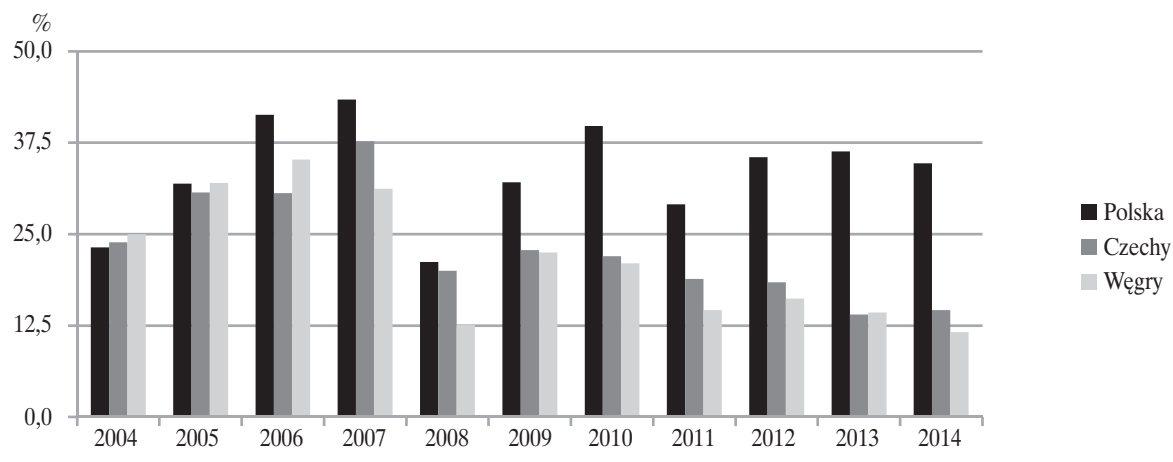

Źródło: NBP, 2004-2015.

Ogłoszony przez wicepremiera M. Morawieckiego Plan na rzecz Odpowiedzialnego Rozwoju, a w jego ramach Plan Budowy Kapitału, zakładają bardzo dużą partycypację rynku kapitałowego w skutecznej ich realizacji. Można nawet zaryzykować stwierdzenie, że bez dobrze działającego rynku kapitałowego nie da się tego planu zrealizować albo realizacja będzie ograniczona. Wskazuje to na konieczność holistycznego i strategicznego podejścia do rozwoju i przyszłości polskiego rynku kapitałowego. Od roku 2010 bowiem, do którego miała obowiązywać strategia Warsaw City 2010, nie powstał żaden dokument odpowiedniej rangi, który wskazywałby na przewidywane kierunki rozwoju rynku kapitałowego w Polsce w perspektywie średnio- i długoterminowej. Nawoływanie środowiska rynku kapitałowego m.in. Izby Domów Maklerskich do podjęcia prac nad jej napisaniem odniosły taki skutek, że na forum Rady Rozwoju Rynku Finansowego - działającej przy Ministrze Finansów - podjęto 
prace nad strategią (tab. 2). Strategia taka powinna być jednak przygotowana we współpracy ze wszystkimi instytucjami rynku kapitałowego, ze szczególną rolą GPW w Warszawie S.A. jako centralnej instytucji tego rynku. Nie wydaje się możliwe oderwanie strategii rozwoju tego rynku w Polsce od planów gospodarczych rządu ani też brak wsparcia dla ich realizacji.

\section{Ta be la 2. Obszary strategii rozwoju rynku kapitałowego w Polsce wg RRRF}

\begin{tabular}{|c|c|}
\hline Obszar & Dzialania \\
\hline $\begin{array}{l}\text { 1. Pobudzenie długoterminowego } \\
\text { oszczędzania }\end{array}$ & $\begin{array}{ll}- & \text { wprowadzenie nowych produktów finansowych } \\
\text { - } & \text { wprowadzenie nowych rozwiązań instytucjonalnych } \\
& \text { przy uwzględnieniu bezpieczeństwa systemu } \\
\text { emerytalnego i perspektywy zakończenia } \\
\text { korzystania przez Polskę z funduszy unijnych }\end{array}$ \\
\hline $\begin{array}{l}\text { 2. Wzmocnienie rozwoju inwestycji } \\
\text { długoterminowych }\end{array}$ & $\begin{array}{l}\text { - } \text { wzmocnienie roli funduszy private equity, venture } \\
\text { capital i funduszy strukturalnych } \\
\text { - } \text { rozwój alternatywnych form finansowania }\end{array}$ \\
\hline $\begin{array}{l}\text { 3. Stworzenie rozwiązań regionalnych } \\
\text { w ramach systemowej globalizacji } \\
\text { i standaryzacji rynku kapitałowego }\end{array}$ & $\begin{array}{l}\text { - uwzględnienie potrzeb małych i średnich } \\
\text { przedsiębiorstw, zwłaszcza w zakresie pozyskiwania } \\
\text { finansowania za pośrednictwem rynku lokalnego }\end{array}$ \\
\hline $\begin{array}{l}\text { 4. Zmiany w zakresie nadzoru nad } \\
\text { rynkiem finansowym }\end{array}$ & 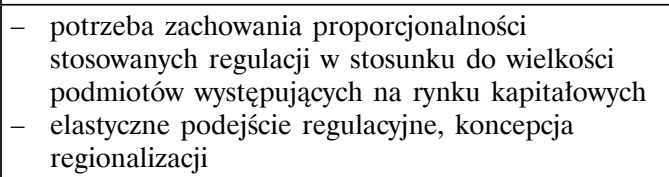 \\
\hline $\begin{array}{l}\text { 5. Problematyka opodatkowania rynku } \\
\text { finansowego }\end{array}$ & $\begin{array}{l}\text { - wypracowanie mechanizmów fiskalnych } \\
\text { stymulujących pożądane mechanizmy i instrumenty } \\
\text { rynkowe }\end{array}$ \\
\hline $\begin{array}{l}\text { 6. Zapewnienie stabilności przepisów } \\
\text { regulujących funkcjonowanie rynku } \\
\text { finansowego }\end{array}$ & $\begin{array}{l}\text { - } \text { aktywność uczestników rynku w pracach } \\
\text { legislacyjnych na poziomie krajowym i europejskim }\end{array}$ \\
\hline \multicolumn{2}{|c|}{$\begin{array}{l}\text { 7. Dalsze wykorzystywanie dialogu regulator/nadzorca/rynek/klient jako skutecznego narzędzia } \\
\text { identyfikacji nieefektywnych mechanizmów i regulacji, stanowiących bariery w dostępie do } \\
\text { rynku }\end{array}$} \\
\hline 8. Wzmocnienie działań edukacyjnych & $\begin{array}{l}\text { u podniesienia wśród społeczeństwa świadomości na } \\
\text { vym }\end{array}$ \\
\hline
\end{tabular}

Źródło: opracowanie własne na podstawie informacji Stowarzyszenia Emitentów Giełdowych. Pozyskano z: www.seg.org.pl (27.10.2016).

\section{Propozycje działań zwiększających znaczenie rynku kapitałowego w Polsce w finansowaniu gospodarki i w regionie Europy Środkowo-Wschodniej}

Unia rynków kapitałowych to dla Polski szansa na zwiększenie dostępu przedsiębiorstw do finansowania rynkowego, lecz również potencjalnie - zagrożenia, jeśli nie podejmie się aktywnych działań na poziomie narodowym w celu zwiększenia konkurencyjności krajowego rynku kapitałowego. Wyspe- 
cyfikowane zagrożenia, jakie niesie dla polskiego rynku kapitałowego pełna implementacja europejskiej unii rynków kapitałowych w perspektywie 2019 r., wskazują na konieczność tworzenia mechanizmów i regulacji wspierających lokalnie dostęp do finansowania rynkowego przedsiębiorstw z sektora MŚP. Istnieje potrzeba komplementarnych rozwiązań dla mniejszych, lokalnych rynków, takich jak rynek polski. Jednym z kierunków jest dążenie do stworzenia w Warszawie centrum kapitałowego dla Europy Środkowo-Wschodniej, które stanowiłoby przeciwwagę dla największych rynków kapitałowych. Chodzi w szczególności o osiągnięcie określonej skali działania takiego centrum, co będzie się przekładało na obniżenie kosztów, które w przypadku funkcjonowania odrębnych rynków lokalnych są wysokie.

Działania strategiczne w zakresie rozwoju rynku kapitałowego są konieczne, aby giełda mogła się dalej rozwijać, a jej rola w finansowania gospodarki - wzrastać. Wybrane działania przedstawiono na schemacie 1.

\section{S c h e m a t 1. Działania na rzecz zwiększenia roli GPW w Warszawie w finansowaniu polskiej gospodarki}
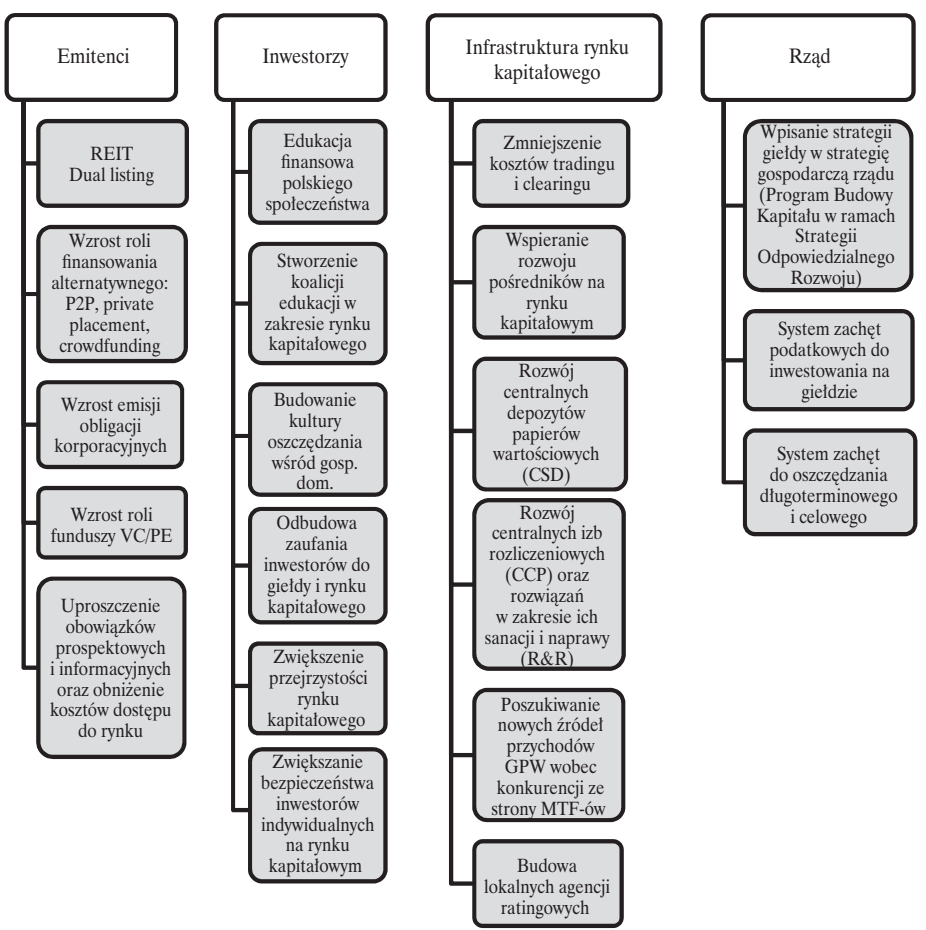

Źródło: opracowanie własne. 
Charakter wyzwań, które stoją przed GPW w Warszawie sprawia, że potrzebne jest spoiwo łączące dwie wizje: rozwoju polskiego rynku kapitałowego i polskiej gospodarki. Strategia rozwoju rynku kapitałowego w Polsce powinna być zgodna $\mathrm{z}$ długoterminowymi planami gospodarczymi rządu. Z kolei, konkurencja ze strony alternatywnych platform obrotu (MTF-ów) wymusza na tradycyjnych giełdach - w tym na GPW - konieczność poszukiwania nowych źródeł przychodów (Zaleska, 2016).

Ważnym aspektem przyszłej strategii rozwoju rynku kapitałowego jest przyciąganie nowych emitentów. Może się to odbywać poprzez uproszczenie obowiązków prospektowych i informacyjnych, zmniejszenie kosztów dostępu do rynku kapitałowego. Propozycją wartą uwagi są tzw. REIT-y oraz podwójne notowanie spółek (dual listing). Należy rozwijać alternatywne formy finansowania, takie jak private placement, pożyczki prywatne (P2P), crowdfunding, fundusze podwyższonego ryzyka $\mathrm{VC} / \mathrm{PE}$.

Przyciąganie inwestorów na rynek kapitałowy to poważne wyzwanie strategiczne, które stoi przed tym rynkiem. W pierwszej kolejności musi nastąpić odbudowa i zwiększanie zaufania inwestorów do giełdy jako miejsca bezpiecznego inwestowania oraz mobilizacja długoterminowych oszczędności gospodarstw domowych za pomocą zachęt podatkowych. Może się to odbyć poprzez edukację uczestników rynku realizowaną przez różne instytucje. W zakresie oszczędzania indywidualnego Polska ma ogromny dystans do nadrobienia. Według najnowszego badania Fundacji Kronenberga i stanu na wrzesień 2016 r. 54\% Polaków oszczędza, ale tylko 13\% regularnie, a 41\% od czasu do czasu, chociaż na poziomie deklaracyjnym $70 \%$ uważa, że warto oszczędzać (Fundacja Kronenberga przy Citi Handlowy, 2016). Należy zwiększać przejrzystość rynku kapitałowego oraz bezpieczeństwo inwestorów. Wyzwaniem jest odwrócenie malejącego udziału inwestorów indywidualnych w obrotach akcjami na rynku głównym z 34\% w I półroczu 2017 r. do 13\% w I półroczu 2016 r. (GPW, 2016).

Wspieranie rozwoju infrastruktury rynku kapitałowego powinno dotyczyć $\mathrm{z}$ jednej strony działania na rzecz poprawy warunków działania pośredników finansowych na rynku kapitałowym (maklerzy, brokerzy), którzy od kilku lat osiągają stratę na podstawowej działalności operacyjnej, poprzez m.in. obniżenie kosztów związanych $\mathrm{z}$ obecnością i działalnością na tym rynku, a także wspierania rozwoju centralnych depozytów papierów wartościowych (CDS) i centralnych izb rozliczeniowych (CCP), w tym ich sanacji i naprawy (R\&R). Poważnym wyzwaniem jest powstanie i wspieranie lokalnych agencji ratingowych, wspomagających inwestorów w ocenie wiarygodności finansowej emitentów z sektora MŚP. 


\section{Podsumowanie}

Unia rynków kapitałowych jako projekt mający na celu skuteczne pobudzanie wzrostu gospodarczego w UE, poprzez zwiększenie dostępności finansowania rynkowego dla przedsiębiorstw z sektora MŚP, nie zastąpi podejmowanych na rodzimym gruncie rozwiązań dla problemów, przed którymi stoi rynek kapitałowy w Polsce. Potrzeba wspierania przez rząd rozwoju giełdy papierów wartościowych jako centralnej części tego rynku, mobilizacja oszczędności długoterminowych gospodarstw domowych oraz szeroko zakrojona akcja edukacyjna polskiego społeczeństwa co do miejsca i roli rynku kapitałowego w gospodarce oraz możliwości inwestowania w instrumenty rynku kapitałowego, to działania długoterminowe, na pewno wykraczające poza 2019 r. wskazany jako data pełnego wdrożenia tego projektu. Ich znaczenie rośnie także w kontekście wcześniej nie przewidywanych zmian systemowych w rozwiniętych gospodarkach, takich jak Brexit czy wyniki wyborów prezydenckich w Stanach Zjednoczonych. Wskazane działania są zatem pilne i muszą zostać zrealizowane przy pełnej współpracy uczestników rynku kapitałowego, aby rola rynku kapitałowego w finansowaniu gospodarki w Polsce zwiększała się, podobnie jak i rola GPW w regionie Europy Środkowo-Wschodniej jako lokalnego centrum kapitałowego.

\section{Bibliografia}

Bitner, M., Bukowski, M. i Siedlecka, U. (2016). Poryw i flauta. Czy gietda napędza polska gospodarkę? Warszawa: WiseEurope, czerwiec. Pobrano z: www.wz.uw.edu.pl/files/aktualnosci_pliki/Poryw-i-Flauta_paper_online_1.pdf.

Bitner, M. (2016). Unia Rynków Kapitałowych. Czy może i powinna stużýc rozwojowi lokalnego rynku kapitatowego? Warszawa, 17.06.2016 r. Pobrano z: https://drive.google.com/ file/d/0B3gPn3GQEUvGajFrb0VtR3F6cVE/view?usp=sharing.

Brunsden, J. (2016). Brexit makes EU capital markets union more urgent. Financial Times, 14 September.

Directive 2014/57/EU of the European Parliament and of the Council of 16 April 2014 on criminal sanctions for market abuse (market abuse directive). Official Journal of the European Union L 173/179.12.6.2014.

Directive 2014/65/EU of the European Parliament and of the Council of 15 May 2014 on markets in financial instruments. Official Journal of the European Union L 173/349.12.6.2014.

Fundacja Kronenberga przy Citi Handlowy (2016). Postawy Polaków wobec finansów. Badanie Fundacji Kronenberga przy Citi Handlowy i Fundacji Think!, wrzesień. Pobrano z: http://www.citibank.pl/poland/kronenberg/polish/files/postawy_polakow_wobec_finansow_wrzesien_2016.pdf.

GPW. (2015). Unia rynków kapitatowych. Stanowisko GPW w Warszawie S.A. w sprawie koncepcji unii rynków kapitatowych. Warszawa: GPW. 
GPW. (2016). Zagregowane wyniki badania dot. udziału inwestorów w obrotach instrumentami finansowymi 2002-I pótrocze 2016. Warszawa: GPW. Pozyskano z: www.gpw.pl (30.10.2016).

IPO Watch Europe. (2016). PwC. Pobrano z: https://www.pwc.pl/pl/pdf/ipo-watch-europe2016-pwc.pdf.

Jóźwiak, T. (2016). Hossa rodzi się w bólach. Gazeta Bankowa, 7.

Jóźwik, T. (2016a). Krok w kierunku Unii Rynków Kapitałowych. Dziennik Gazeta Prawna, 29 września.

Jóźwik, T. (2016b). Rynek do naprawienia. Gazeta Bankowa, 6.

Kachniewski, M. (2016). Unia rynków kapitałowych spowoduje odplyw emitentów z polskiego rynku. Pobrano z: www.newseria.pl (23.10.2016).

KE. (2016). Komunikat Komisji do Parlamentu Europejskiego, Rady, Europejskiego Banku Centralnego, Europejskiego Komitetu Ekonomiczno-Społecznego i Komitetu Regionów. Unia rynków kapitałowych - przyspieszenie reformy, Bruksela, 14.09.2016 r., COM(2016) 601 final.

NBP. (2004-2015). Rozwój systemu finansowego za lata 2004-2014. Warszawa: NBP. Pozyskano z: http://www.nbp.pl/home.aspx?f=/systemfinansowy/rozwoj.html.

Regulation (EU) No 596/2014 of the European Parliament and of the Council of 16 April 2014 on market abuse. Pobrano z: http://eur-lex.europa.eu/legat-content/EN/TXT/?uri$=$ celex\%3A32014R0596.

State of the Union 2016: Completing the Capital Markets Union - Commission accelerates reform, Strasbourg, 14 September 2016. Pobrano z: http://europa.eu/rapid/press-release_IP-16-3001_en.htm.

Wright, W. (2016). The potential impact of Brexit on capital European markets in Europe. A qualitative survey if market participants, New Financial, April. Pozyskano z: www. newfinancial.eu_(26.10.2016).

www.seg.org.pl (27.10.2016).

Zaleska, M. (2016). Sukces nie jest dany raz na zawsze. Gazeta Bankowa, 9. 


\section{Rozdział II}

\section{MAŁGORZATA OLSZAK*, MATEUSZ PIPIEŃN**, IWONA KOWALSKA**, SYLWIA ROSZKOWSKA ${ }^{* * * *}$}

\section{The Impact of Capital on Lending in Publicly-Traded and Privately-Held Banks in the $\mathrm{EU}$}

This paper extends the literature on the link between lending and capital by examining the role of equity ownership structure for this link in banks operating in the European Union. As the theory predicts, publicly-traded banks are more prone to heightened agency problems (moral hazard and adverse selection) due to dispersed ownership and therefore have stronger incentives to engage in excessive risk-taking, especially in economic expansions. This may bring about a procyclical lending effect in economic downturns. Furthermore, the theory predicts that these banks are also more affected by capital market frictions in economic downturns. Applying Blundell and Bond (1998) two step robust GMM estimator, we predict and find that the link between lending and capital in economic downturns is stronger in publicly-traded banks than in privately-held banks, which may be a result of greater conditional accounting conservatism of publicly-traded banks. Additionally, the link between lending and capital during expansions is stronger in the case of privately-held banks reporting unconsolidated data, but not for banks reporting consolidated financial reports, consistent with the view that limited access to capital markets increases the cost

dr hab. Małgorzata Olszak - Department of Banking and Money Markets, Faculty of Management, University of Warsaw, Poland, ul. Szturmowa 1/3, 02-678 Warsaw, Poland; e-mail address: molszak@wz.uw.edu.pl.

** dr hab. Mateusz Pipień, prof. UEK - Department of Econometrics and Operations Research, Cracow University of Economics, Poland; e-mail address: eepipien@cyf-kr.edu.pl.

*** dr Iwona Kowalska - Department of Mathematical and Statistical Methods, Faculty of Management, University of Warsaw, Poland; e-mail address: IKowalska@wz.uw.edu.pl.

**** dr Sylwia Roszkowska - Chair of Macroeconomics, Faculty of Economic and Social Sciences, University of Łódź, Poland; e-mail address: sylwiaroszkowska@gmail.com. 
of external finance of private banks. Finally, we find empirical support for the view that lending of privately-held banks is not constrained by the capital ratio in economic downturns. Our results stress the importance of conditional conservatism for the effectiveness of the macroprudential policy, in particular countercyclical capital buffers.

Keywords: loan supply, capital ratio, procyclicality, accounting conservatism, privately-held and publicly-traded banks.

\section{Wpływ kapitałów na aktywność kredytową banków giełdowych i nienotowanych na giełdzie $w$ UE}

Artykuł mieści się w nurcie literatury przedmiotu badającej wpływ struktury własnościowej na związek między aktywnością kredytową i wskaźnikiem kapitałowym. Jak wynika z teorii, banki notowane na giełdzie są bardziej podatne na uboczne efekty wynikające z relacji agent-pryncypał (pokusa nadużyć i negatywna selekcja) ze względu na rozproszoną strukturę własności. Stąd też mogą być bardziej podatne na podejmowanie nadmiernego ryzyka w okresie ożywienia. Może to skutkować wzrostem procykliczności aktywności kredytowej banków w okresie dekoniunktury. Banki te mogą być również bardziej podatne na zaburzenia w funkcjonowaniu mechanizmu rynkowego na rynku kapitałowym. Z zaprezentowanego w artykule badania wynika, że związek między aktywnością kredytową i wskaźnikiem kapitałowym jest silniejszy w okresie dekoniunktury w bankach giełdowych niż w bankach, które nie są notowane na giełdzie. Natomiast w okresie dobrej koniunktury, związek ten jest silniejszy w bankach nienotowanych na giełdzie i raportujących nieskonsolidowane sprawozdania finansowe, co jest zgodne z koncepcją, że ograniczony dostęp do rynku kapitałowego prowadzi do wzrostu kosztów zewnętrznego finansowania tych banków. Aktywność kredytowa banków w tej grupie nie jest jednak podatna na ograniczenie związane ze wskaźnikiem kapitałowym w okresie dekoniunktury.

Słowa kluczowe: podaż kredytu, wskaźnik kapitałowy, procyckliczność, konserwatyzm księgowy, bank giełdowy, bank prywatny.

JEL: E32, G21, G28, G32

\section{Introduction}

In this paper, we ask whether the capital ownership structure affects the link between lending and capital in both economic expansions and economic downturns. To date, research has provided little insight into this question, in part because of the scarcity of interest in this issue in the buoyant pre-crisis period, where the relationship between capital and lending seemed to be of no importance for the economic growth. This study provides empirical evidence on the relation between equity ownership (i.e. whether common equity shares 
are publicly-traded or privately-held) and the link between loan growth and capital ratio for a sample of EU banks.

In this paper, we develop and test three sets of predictions about how public versus private ownership drives differences in the link between lending and capital. In the first set, we predict that publicly-traded banks are more capital-constrained during economic downturns than privately-held banks, which may be attributed to excessive risk-taking of publicly-traded banks in economic expansions or a greater degree of conditional accounting conservatism of public banks. In the second set, we predict that privatelyheld banks are more capital-constrained in expansions - due to limited access to liquid equity capital markets. The lending of these banks will be less constrained by capital in economic downturns because of the importance of relationship banking and irrelevance of access to the equity capital market. According to the third set of predictions, the lending of privately-held banks is not constrained by the capital ratio in economic downturns.

Economic theory and empirical evidence suggest a very wide range of possible values of the impact of a change in bank capital on bank's assets (and their composition) and, consequently, its lending (for a review see e.g. Borio and Zhu, 2012; Berrospide and Edge, 2010; Beatty and Liao, 2014). On the one hand, there is a possibility that a reduction in bank capital, which results from serious losses, can be absorbed without any change in bank assets - and thereby in bank lending - probably due to the high capital buffers (Fonseca and González, 2010) the bank has both before and after the losses, and because a capital decline can be offset by supplementary sources of funding. In this extreme, a unit reduction in bank capital results in no reduction in bank lending.

There is also a possibility that banks very actively manage the composition of their assets to keep a fixed relationship between capital and assets since they have very limited access to external financing and thus have difficulties in raising equity to offset declines in bank capital. In this case, a bank attempting to maintain a constant capital ratio must reduce its asset levels or change asset composition by decreasing the amount of risky loans and investing more in risk-free government bonds (Berger and Udell, 1994; Wagster, 1999). Whatever method the bank chooses to keep the relationship between capital and assets fixed, the amount of risky assets, i.e. loans, must be adjusted.

We expect that the relationship between lending and capital is diversified, and that this diversity may be attributed to fundamental decisions of bank owners about being publicly traded or privately held. Previous research on the role of the ownership structure stresses its importance for bank conditional accounting because of organizational differences in the control structure 
and capital market access (see Nichols et al., 2009). The control structure, or monitoring of banks, is also an important driver of bank risk-taking. Conditional conservatism in earnings recognition and loan loss accounting has salient consequences for the earnings retention capabilities of banks and, therefore, explains the levels of bank capital buffers. Low capital buffers have a negative impact on bank lending extension and create a supply side pressure on credit market, in particular during economic downturns.

To test our hypotheses, we apply a two-step GMM robust estimator (Arrelano and Bond, 1991; Blundell and Bond, 1998) for data spanning 1996-2011 on individual banks available in the Bankscope database. Our study is important for the current regulatory challenges, in particular those related to macroprudential policy (FSB, BIS, IMF, 2011; IMF, 2011; Claessens, 2014; Claessens et al., 2014). If our predictions are supported by the results of our study, then it seems vital that bank regulators consider the role of the capital ownership structure in the process of deciding on the levels of countercyclical buffers designed in the Basel III (see BCBS, 2011).

In preview, we find that publicly-traded banks exhibit greater sensitivity of loan growth to capital ratios in economic downturns. Additionally, privatelyheld banks' lending is more affected be the capital ratio during economic expansions, whereas in poor macroeconomic environment, the capital ratio does not seem to have a significant impact for their credit extension. Following the results of our study, we recommend that macroprudential policy supervision considers the fact that the degree of conditional conservatism in earnings recognition and loan loss accounting affects publicly-traded banks' ability to absorb unexpected loan losses and thus makes their loan growth more sensitive to the capital ratio.

The rest of the paper is organized as follows. In Section 2, we present theoretical background of our study and develop our hypotheses. We describe our sample and research design in Section 3. We discuss results in Section 4. Section 5 concludes our work.

\section{Theoretical and empirical background and hypotheses development}

There are many studies focusing on the relationship between lending and capital (for a review see Beatty and Liao, 2014 and Olszak et al., 2014, pp. 38-40). Of those studies, only two papers focus on the impact of capital on lending in publicly-traded banks (Beatty and Liao, 2011; Gambacorta and Marqués-Ibáñez, 2011), but they do not consider the role of being privatelyheld for the link between capital and lending. Similarly to other firms, banks 
that fulfil regulatory requirements established in the EU (see CRD IV and CRR) and in particular EU countries can choose to have their equity listed on an exchange market or can retain private ownership. As Nichols et al. (2009) find, such a choice has implications for conditional conservatism in bank accounting. In particular, they find that publicly-traded banks exhibit greater degrees of conditional conservatism (i.e. asymmetric timeliness of the recognition of losses versus gains in accounting income) than private banks (see also Beatty et al., 2002). Moreover, public banks recognize more timely earnings declines, less timely earnings increases, and larger and more timely loan losses. This research thus shows that the equity ownership structure has meaningful implications for conditional conservatism in bank accounting. However, this study does not consider the consequences of differences in the equity ownership structure for the link between lending and capital. Theoretically, the equity ownership structure can affect the relationship between the lending extension activity and the capital ratio because it triggers differences along two organizational areas of a bank - monitoring (or control) and equity market access. Of those two, the monitoring has also implications for accounting, in particular for conditional conservatism.

\subsection{Monitoring problems and conditional accounting conservatism}

The need for monitoring is especially salient within banks due to the high potential for information asymmetry, which arises between bank managers and its shareholders and between the bank and its external stakeholders (Stultz, 2014; IMF, 2014). This information asymmetry results in the potential for moral hazard and adverse selection problems (Jensen and Meckling, 1976; Ang et al., 2000), and therefore determines the risk-taking incentives of a bank. The risktaking incentives of a bank depend on the separation between bank managers and shareholders and between the bank and its stakeholders. Privately-held banks are more likely to be closely interrelated, with managers usually being major shareholders, which implies that they bear a higher proportion of the costs of these actions than public bank managers. In effect, the internal monitoring is definitely stronger, and consequently the risk-taking incentives are reduced. In contrast, equity holders of publicly-traded banks cannot monitor the risk-taking activities of managers as closely, may have difficulties in the access to private information of managers, who may engage in more risk-taking than shareholders desire. In such banks, equity ownership tends to be more dispersed, which creates a heightened potential for agency problems (moral hazard and adverse selection). Given these problems, rational owners and 
managers in these banks develop elaborate corporate governance structures which aim to reduce the side effects of this dispersed ownership. However, the externality of such structures is greater risk-taking (IMF, 2014; Stultz, 2014).

The theory thus suggests that publicly-traded banks are more prone to excessive risk-taking. Such excessive risk-taking takes place usually in expansions and results in heightened risk aversion during economic downturns. Consequently, to reduce the risks, publicly-traded banks may be more reluctant to extend new lending in unfavorable economic conditions, exactly when such lending is necessary to boost investments in the real economy. This excessive risk aversion in economic downturns should result in a heightened association between lending and capital. This brings us to put forward the following hypothesis:

\section{Hypothesis 1: The link between lending and capital in economic downturns is stronger in publicly-traded banks than in privately-held banks.}

The prediction of a stronger impact of capital on lending in economic downturns in publicly-traded relative to privately-held banks can also be supported by the accounting literature, in particular its strand focusing on conditional conservatism (Beaver and Ryan, 2005; Nichols et al., 2009). Accountants traditionally expressed conservatism by the adage "anticipate no profit, but anticipate all losses (Bliss, 1924). As Watts suggests (2003, p. 208), conservatism does not imply that all revenue cash flows should be received before profits are recognized, but rather that those cash flows should be verifiable. Basu (1997, p. 7) interprets this adage as representing "the accountant's tendency to require a higher degree of verification to recognize good news as gains than to recognize bad news as losses". Watts (2003, p. 208) also states "that conservatism is the asymmetrical verification requirements for gains and losses, thereby allowing for degrees of conservatism: the greater the difference in degree of verification required for gains versus losses, the greater the conservatism". Beaver and Ryan (2005, pp. 269-270) refer to the asymmetric timeliness of gain recognition as good news and loss recognition as bad news as conditional conservatism (see also Demski, 2004, p. 522).

Ball and Shivakumar (2005) and Watts (2003) argue that conditional conservatism reduces managerial opportunism in financial reporting by counteracting managers' opportunism bias and thus facilitates contracting efficiency between the firm and its stakeholders given asymmetric information and payoffs. Following Watts (2003, p. 209), Nichols et al. (2009, p. 94) argue that "the need to limit such managers" opportunism and optimism bias is increasing in information asymmetry" (see Ang et al., 2000). Also, the higher the information asymmetry, the higher the demand for verifiable information. 
As the separation of ownership and monitoring is greater in publicly-traded firms, and thus the information asymmetry is wider, the demand for conditional conservatism is likely to be greater among those firms.

Nichols et al. (2009) predict and give empirical support to the view that publicly-traded banks exhibit greater conditional conservatism than private ones, which has salient consequences for the recognition of earnings and loan loss accounting. Their analysis conducted for U.S. commercial banks over the period of 1990-to 2003 shows that publicly-traded banks recognized earnings increases in a less timely manner than earnings decreases. As for loan loss accounting, their study focuses on three types of loan loss related expenses, i.e.: loan loss provisions, loan loss allowance and loan charge-offs and, additionally, on one type of "income" which is related to the recovery of a portion or all of a previously charged-off loan. Analysis of accounting behavior of U.S. banks lends empirical support to the prediction that publicly-traded banks recognize larger and more timely loan loss provisions relative to changes in nonperforming loans than private banks. Nichols et al. (2009) also find that publicly-traded banks recognize larger loan loss allowances (relative to total loans) than private banks. In the case where loan losses are realized, publicly-traded banks recognize larger and more timely loan charge-offs than privately-held banks. And finally, where banks anticipate that a portion or all of a previously charged-off loan will be recovered, publicly-traded banks recognize smaller and less timely loan recoveries than private banks.

High conditional conservatism in both earnings recognition and loan loss accounting has profound implications for the bank's ability to absorb unexpected loan losses, covered traditionally with bank's capital. Less timely earnings recognition, in particular during economic booms, gives rise to a reduced amount of retained earnings which could be applied to increase bank capital buffers, and therefore creates a potential supply side burden on lending extension during economic downturns. This effect is strengthened by larger and more timely loan loss provisions and loan loss allowance (negatively affecting bank net income in economic upturns) and larger and more timely charge-off recognition which takes place during poor economic conditions (and resulting in a further decline in bank net income).

\subsection{Capital market access issues and conditional conservatism}

The decision to be a public or a private bank is inherently determined by the need to access the equity capital market. This implies differences in the cost of equity capital as well as external financing costs involved in raising 
new equity, during both economic expansions and downturns. In economic expansions, publicly-traded banks incur low transaction costs of external financing due to high liquidity of the capital market. Consequently, their lending activity is not constrained by the levels of the capital ratio. In case they needed more capital to cover increased demand for lending in expansions, they may raise new equity through seasoned equity offerings (see e.g. Nichols et al., 2009). Such equity raising options are also available to private banks but require them to go public and to pay for the access to the capital market. This implies that privately-held banks may be more capital-constrained in economic expansions than publicly-traded banks. We thus put forward the following hypothesis:

\section{Hypothesis 2: The link between lending and capital during expansions is stronger in the case of privately-held banks.}

The theory predicts that the equity capital market access is exacerbated and the transaction costs involved in raising equity are heightened during recessions (the so-called capital crunch effect). Generally, in economic downturns banks are facing external financing frictions (such as Myers and Majluf (1984) adverse selection problem) (see also Borio and Zhu, 2012). In this line, Peek and Rosengren (1995) test the capital crunch theory suggesting that capital market imperfections making it difficult to raise new external equity capital will lead the banks concerned about potential future capital constraints to reduce their lending in recessions. They find that Basel I capital requirements prompted banks to reduce lending due to difficulties in extending capital. Such effect is also found for publicly-traded banks by Beatty and Liao (2011) and Gambacorta and Marqués-Ibáñez (2011). Publicly-traded banks' lending is definitely more affected by the capital ratio during downturns because sudden increases in costs of external finance are compounded by decreases in reported earnings and increases in loan charge-offs, as is explained by the conditional conservatism literature (Nichols et al., 2009).

In contrast, privately-held banks do not have easy access to capital markets in expansions, so they do not find increased transaction costs in downturns as a constraint for their lending activity. They are accustomed to conducting their business exploiting internal finance to a greater extent. Moreover, due to their potentially local activity, they may be more engaged in creating stronger ties with their customers (e.g. applying relationship banking strategies). Additionally, Nichols et al. (2009) find that those banks engage in conditional conservatism to a lesser extent than publicly-traded banks. Therefore, their net income and capital ratios are less affected by loan loss provisions, loan loss allowances and loan charge-offs. Considering this, we expect that: 
Hypothesis 3: Lending of privately-held banks is not constrained by the capital ratio in economic downturns.

\section{Data and research methodology}

\subsection{Data}

We use pooled cross-section and time series data of individual banks' balance sheet items and profit and loss accounts from 27 EU countries and country-specific macroeconomic indicators for these countries, over the period from 1996 to 2011. The balance sheet and profit and loss account data were taken from the Bankscope database, whereas the macroeconomic data were accessed from the EUROSTAT and the IMF web pages. We look at both unconsolidated and consolidated data in a separate analysis to take account of the fact that banks type of consolidation is a proxy for bank size. We expect that the capital effect on lending is stronger in the case of publiclytraded banks reporting consolidated financial statements. We exclude from our sample outlier banks by eliminating the extreme bank-specific observations when a given variable adopts extreme values. Since most of these institutions are located in Ireland, the number of countries included in the final sample drops to 26. Based on this selection strategy, the number of banks included in our sample is 2523 in the case of unconsolidated data (27359 observations and 26 countries) and 357 banks ( 3776 bank year observations) in the case of consolidated financial data.

\subsection{The econometric model}

The empirical models that addressed the question of whether a bank-capital induced credit crunch was hindering the recovery were developed in the earlyand mid-1990s in the U.S. We follow contemporary versions of those models available in several studies (Berrospide and Edge, 2010; Beatty and Liao, 2011; Carlson et al., 2013; Labonne and Lame, 2014; Bridges et al., 2014). Our basic model is given in equation (1) and reads as follows:

$$
\begin{aligned}
& \Delta \text { Loan }_{i, t}=\alpha_{1} \Delta \text { Loan }_{i, t-1}+\alpha_{2} \Delta \text { Loan }_{i, t-2}+\alpha_{3} \text { Downturn }+\alpha_{4} \text { CAP } P_{i, t}+ \\
& +\alpha_{5} \text { Downturn } * \alpha_{4} \text { CAP }_{i, t}+\alpha_{6} \text { LIQGAP }_{i, t}+\alpha_{7} \text { DEPBANKS } S_{i, t}+ \\
& +\alpha_{8} \Delta C A P_{i, t}+\alpha_{9} Q L P_{i, t}+\alpha_{10} \text { size }_{i, t}+\alpha_{11} \Delta U N E M P L_{j, t}+ \\
& +\alpha_{12} \sum_{j=1}^{27} \text { Country }_{j}+\alpha_{13} \sum_{t=1996}^{2011} T_{t}+\vartheta_{i, t}+\varepsilon_{t}
\end{aligned}
$$


where:

$i$ - the number of bank; $j$ - the number of country; $t$ - the number of observation for the i-th bank; $\triangle$ Loan - annual real loan growth rate; $C A P$ - capital ratio, i.e. equity capital divided by total assets; LIQGAP - liquidity gap, calculated as (loans to nonfinancial sector subtract deposits of nonfinancial sector subtract interbank deposits)/loans to nonfinancial sector; this variable measures the extent to which bank loans are financed by unstable funding (i.e. securitizations, etc.); $D E P B A N K S$ - deposits from banks divided by total assets; $\triangle C A P$ - annual change in capital ratio; $Q L P$ - quality of lending portfolio (it equals loan loss provisions divided by average loans); size - logarithm of assets; $\triangle U N E M P \mathrm{~L}$ - annual change in unemployment rate. Elements $\sum_{j=1}^{27}$ Country $_{j}$ and $\sum_{t=1996}^{2011} T_{t}$ are a set of country and time dummy variables. $\vartheta$ are unobservable bank-specific effects that are not constant over time but vary across banks. Finally, $\varepsilon$ is a white-noise error term.

Considering the fact that we have access to annual data, we relate the loan growth rate to the current period bank specific variables instead of their lagged values. Such a choice is motivated by three reasons. First, when banks design their capital allocation plans, they do it based on the amount of current risks (expressed in the previous level of the capital ratio) and any expected increases in the risks (which result from the loan extension plans) (see Resti and Sironi, 2007, p. 712). Second, the actual lending decisions made throughout the year may also be adjusted taking account of the current changes in bank capital as well as the changes in the quality of credit portfolio (because loan loss charge-offs affect capital through changes in bank profits). This effect would be omitted if the capital ratio was incorporated as lagged. Consistent with this view, Mora and Logan (2012, p. 1109) show that bank capital affects loans contemporaneously, and not only with a lag. Third, the usage of lagged variables would not resolve the problem of simultaneity and the endogeneity bias (see also Roberts and Whited, 2011, p. 32).

We predict a negative coefficient on Downturn if loan supply declines during Downturns for reasons other than capital and liquidity constraints (as do Beatty and Liao, 2011, p. 7). Further, if external financing is not frictionless, and banks are concerned that they might violate capital requirements, then the coefficient on CAP is expected to be positive. That is banks with a higher capital ratio will extend more loans. The coefficient on interaction term between Downturn and CAP is our measure of the capital crunch effect. A positive coefficient implies that lending is constrained by capital in 
economic downturns. A negative coefficient would indicate that capital is not an important determinant of lending extension.

\section{Table 1. Variables description and expected signs in the regressions}

\begin{tabular}{|c|c|c|c|}
\hline $\begin{array}{l}\text { Variable } \\
\text { name }\end{array}$ & Variable description & $\begin{array}{l}\text { Expected } \\
\text { sign }\end{array}$ & Basic argument \\
\hline Sloan & Loan growth rate & & \\
\hline Downturn & $\begin{array}{l}\text { Dummy equal to } \\
\text { one in Downturns } \\
\text { and } 0 \text { otherwise }\end{array}$ & - & $\begin{array}{l}\text { A negative coefficient on Downturn } \\
\text { is predicted if loan supply declines during } \\
\text { Downturns for reasons other than capital } \\
\text { and liquidity constraints. }\end{array}$ \\
\hline Downturn*CAP & $\begin{array}{l}\text { Interaction between } \\
\text { Downturn and } \\
\text { capital ratio (CAP) }\end{array}$ & $+/-$ & $\begin{array}{l}\text { A positive sign is expected if banks' loan } \\
\text { growth is constrained by capital in Downturns, } \\
\text { a negative sign is expected otherwise. }\end{array}$ \\
\hline CAP & $\begin{array}{l}\text { Capital ratio, i.e. } \\
\text { equity capital to } \\
\text { total assets }\end{array}$ & + & $\begin{array}{l}\text { A positive sign is expected if loan growth } \\
\text { is constrained by capital ratio. }\end{array}$ \\
\hline LIQGAP & $\begin{array}{l}\text { Loans less Total } \\
\text { customer deposits } \\
\text { less Deposits from } \\
\text { banks divided by } \\
\text { Loans }\end{array}$ & - & $\begin{array}{l}\text { Banks which have more stable funding } \\
\text { (deposits) relative to loans should be able } \\
\text { to extend loans. The higher the LIQGAP, } \\
\text { the less loans are financed by stable deposits. }\end{array}$ \\
\hline DEPBANKS & $\begin{array}{l}\text { Deposits from banks } \\
\text { to total assets }\end{array}$ & + & $\begin{array}{l}\text { A positive sign is expected if interbank } \\
\text { deposits boost liquidity of a bank and make } \\
\text { lending easier. }\end{array}$ \\
\hline$\triangle \mathrm{CAP}$ & $\begin{array}{l}\text { Annual change in } \\
\text { the capital ratio (i.e. } \\
\text { end of year CAP } \\
\text { subtract beginning } \\
\text { year CAP) }\end{array}$ & - & $\begin{array}{l}\text { To increase the capital ratio, a bank must } \\
\text { either increase its capital (without changes } \\
\text { in risk weighted assets) or decrease risky } \\
\text { loans (without change in capital). }\end{array}$ \\
\hline QLP & $\begin{array}{l}\text { Loan loss provisions } \\
\text { divided by average } \\
\text { loans }\end{array}$ & - & $\begin{array}{l}\text { The higher the share of loan loss provisions } \\
\text { in bank loans, the lower the loan growth. }\end{array}$ \\
\hline Size & $\begin{array}{l}\text { Logarithm of total } \\
\text { assets }\end{array}$ & $+/-$ & $\begin{array}{l}\text { On the one hand, large banks may benefit } \\
\text { from the too-big-to-fail position and thus } \\
\text { might isolate better adverse shocks (a positive } \\
\text { coefficient). On the other hand, in the case } \\
\text { of small banks, strong relationships between } \\
\text { banks and their borrowers may result in } \\
\text { a negative relationship (a negative coefficient). }\end{array}$ \\
\hline$\triangle \mathrm{UNEMPL}$ & $\begin{array}{l}\text { Change } \\
\text { in the annual } \\
\text { unemployment rate }\end{array}$ & - & $\begin{array}{l}\text { The higher the unemployment rate, the lower } \\
\text { the demand for loans, and thus the loan } \\
\text { growth is reduced. }\end{array}$ \\
\hline
\end{tabular}

In Table 1, we present all variables applied in our econometric model with expected impact they have on loan growth. We predict a negative coefficient on Downturn if loan supply declines during Downturns for reasons other than 
capital and liquidity constraints (as do Beatty and Liao, 2011, p. 7). Further, if external financing is not frictionless, and banks are concerned that they might violate capital requirements, then the coefficient on CAP is expected to be positive. That is banks with a higher capital ratio will extend more loans. Additionally, following the concept of conditional conservatism (see Nichols et al., 2009), we expect that loan growth of publicly-traded banks will be more sensitive to the current quality of the loan portfolio (i.e. QLP) than the loan growth of privately-held banks. This means that the regression coefficient measuring the association between loan growth and QLP will be more negative for publicly-traded banks than for privately-held banks.

In our study, we apply the system of the generalized method of moments (GMM) proposed by Blundell and Bond (1998) with Windmeijer correction (2005). We control for the potential endogeneity of CAP, LIQGAP, DEPBANKS, $\triangle \mathrm{CAP}$ and QLP in the two step system GMM estimation procedure by the inclusion of lagged values of explanatory variables as instruments. The UNEMPL, as well as the country and the time dummy variables, are the only variables considered exogenous. As the number of lags of explanatory variables determines the number of instruments - which may proliferate our estimations - we apply a two stage approach in our estimations. In the first stage, we use up to eight lags of explanatory endogenous variables (to take into account the potential impact of the business cycle on the current levels of bank specific variables). In the second stage, we reduce the number of lags up to four. This robustness check is necessary to avoid the problem of biased estimators, i.e. estimators dramatically proliferated by the number of instruments. As the consistency of the GMM estimator depends on the validity of the instruments, we consider two specification tests. The first is the test verifying the hypothesis of absence of second-order serial correlation in the first difference residuals $(\operatorname{AR}(2))$ and the absence of first-order serial correlation in the differentiated residuals $(\mathrm{AR}(1))$. The second test which we apply is the Hansen's J statistic for overidentifying restrictions, which tests the overall validity of the instruments tests (see Roodman, 2009, p. 141).

Our models include a dynamic interaction between the capital ratio and the variables describing changes in economic activity, i.e. economic downturns in each EU country. As there is no comparable dataset including information on business cycle stages in the EU member states, we assessed business cycle fluctuations for the whole set of countries using the Almost Periodically Correlated (APC) stochastic process. This method describes deviations from the long term trend of the GDP growth observed quarterly (see e.g. Parzen and Pagano, 1971; Frances and Dijk, 2005). In our study, we apply 
a dataset covering 72 observations in the period of the 1st quarter of 1995 up to the 4th quarter 2012 in almost all EU countries (but for Croatia, Cyprus, Czech Republic, Iceland, Ireland, Malta, Romania and Spain). The cyclical component, estimated according to the subsampling scheme was applied to assess whether in a particular year the economy was in a downturn or not (Lenart and Pipień, 2013). The Downturn period is identified in the case at least two quarters in a year can be characterized by a slowdown or a recession. This means that in those quarters the deviation from the long term growth trend may be positive or negative, but the changes as compared to the previous quarter should be negative.

\section{Empirical results}

Table 2 reports descriptive statistics and correlations of the key regression variables in the sample of publicly-traded banks, whereas Table 3 includes such statistics and correlations in the sample of privately-held banks. We find a positive and statistically significant correlation between loan growth and capital ratio (in economic expansions) in the samples of publicly-traded and privately-held banks reporting unconsolidated financial statements. In the case of banks consolidating financial statements, those correlations are negative and statistically insignificant. The correlations between capital ratio and loan growth in economic downturns are positive in almost all samples, but for privately-held banks reporting consolidated data. The correlations between loan growth and capital ratio in economic expansions and in economic downturns are thus diversified and may be a result of differences in monitoring and capital market access issues, as suggested in section 2 . 


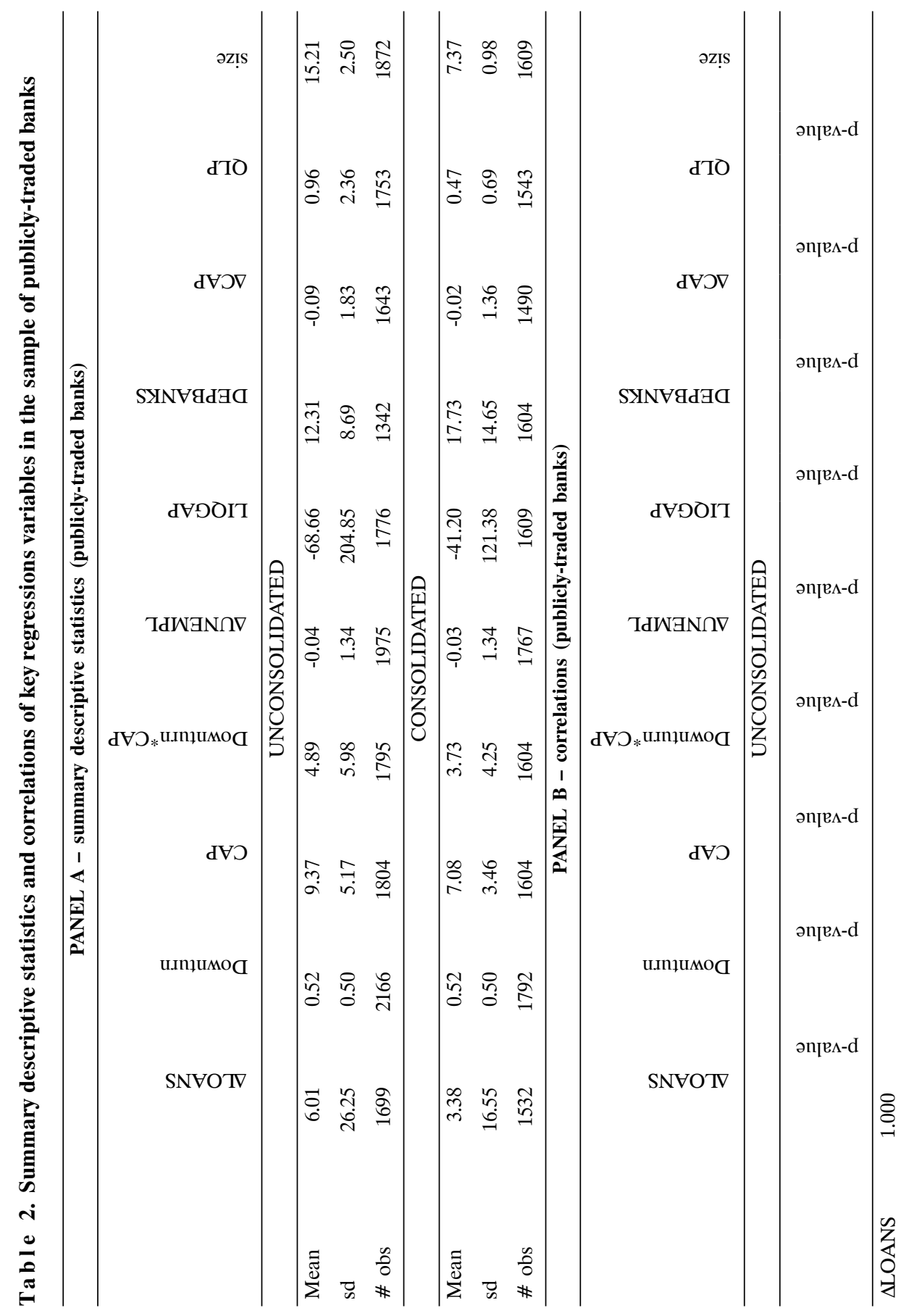




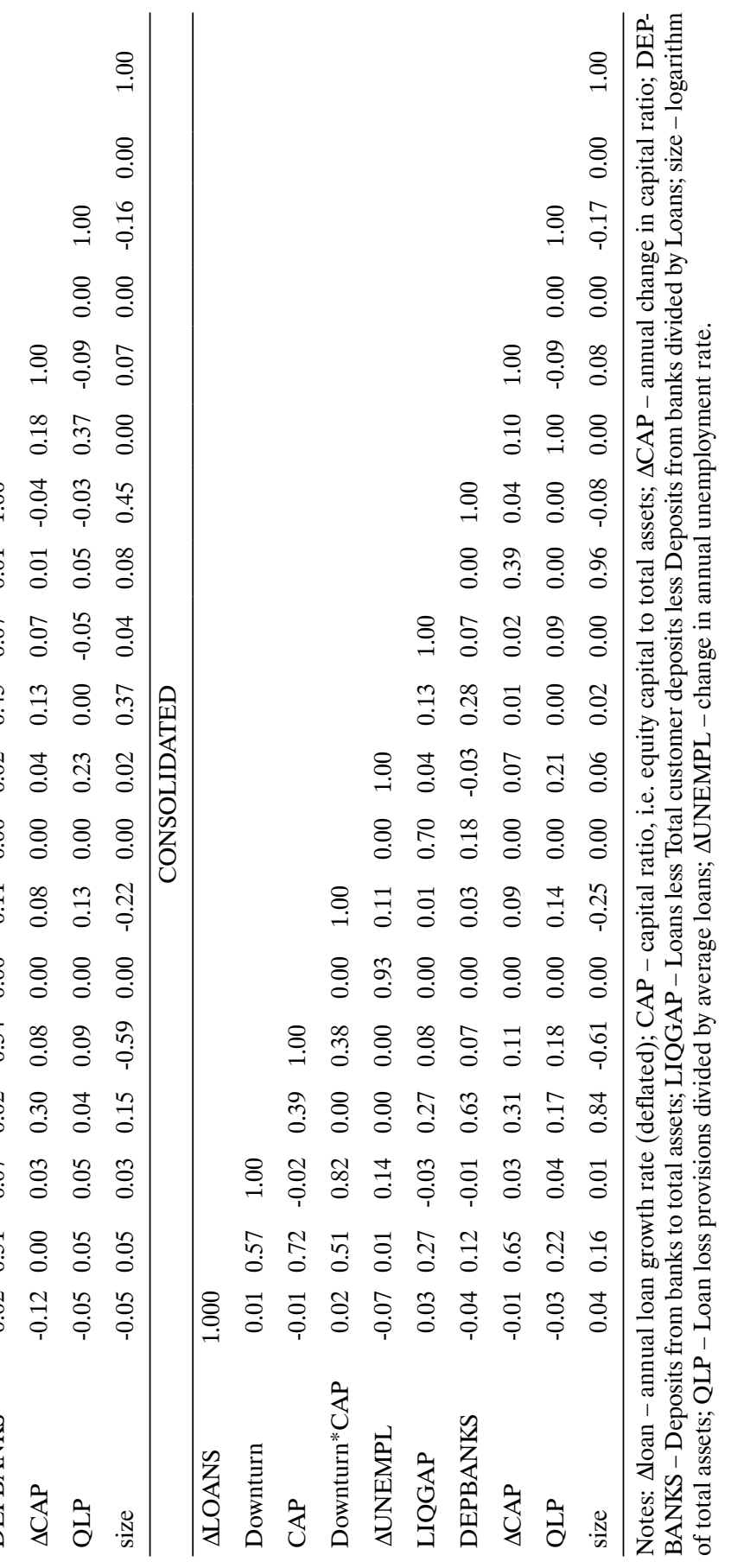




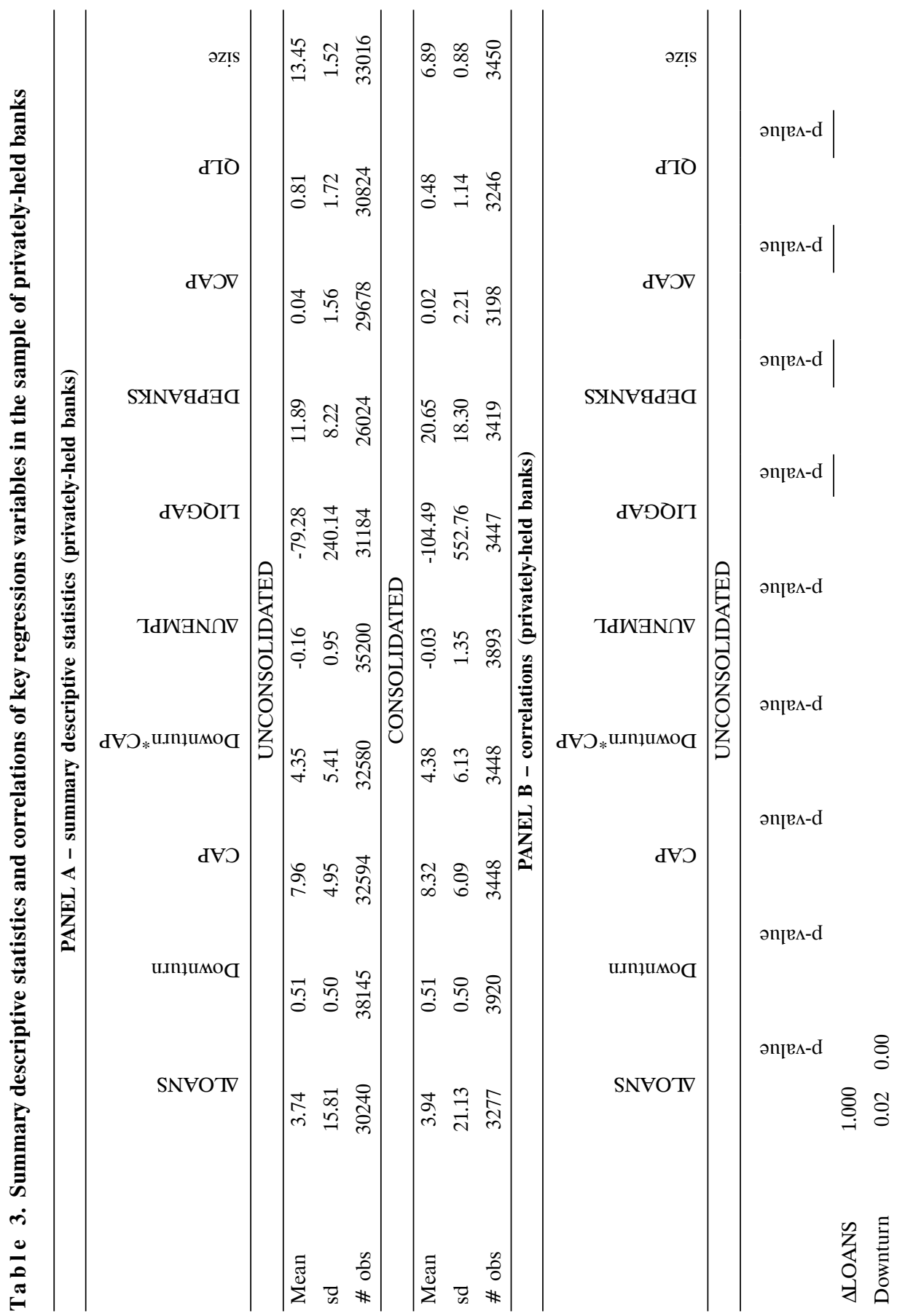




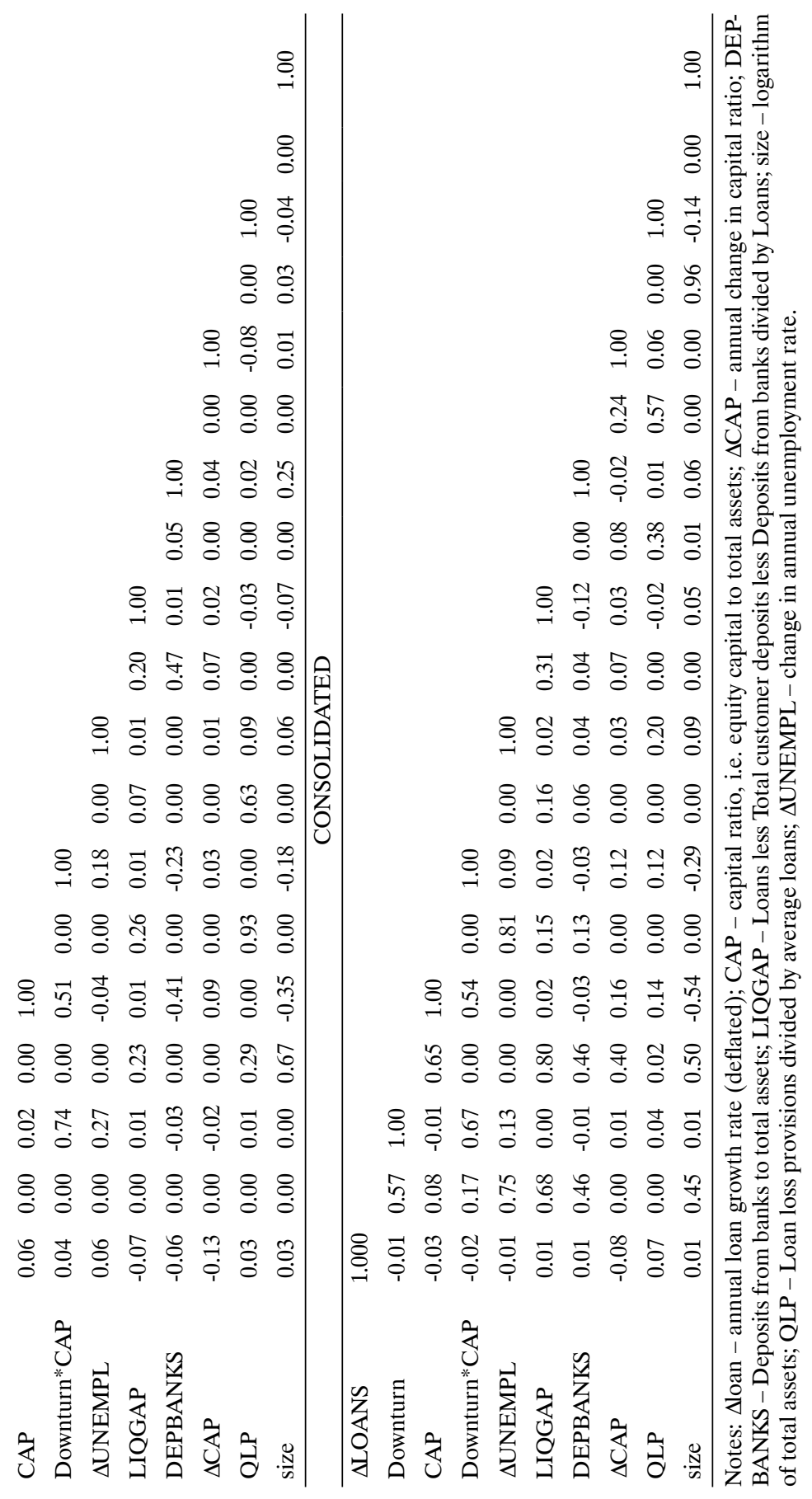


In Table 4, we report results of our estimation conducted in a two stage approach described in section 3.2; in Table 5, we test the sensitivity of regression coefficients to reduced number of instruments (see Roodman, 2009). We find that the coefficient on Downturn*CAP is positive for publiclytraded banks reporting both unconsolidated and consolidated data (see columns 1 and 3 in Table 4). However, this effect is statistically significant only in the sample of banks reporting unconsolidated statements. Such a result is not found for privately-held banks. Thus, this supports our first hypothesis that the link between lending and capital in economic downturns is stronger and economically significant in publicly-traded banks than in privately-held banks.

The coefficient on CAP is positive and statistically significant in the case of privately-held banks reporting unconsolidated data (see column 2 of Table 4). This lends empirical support to our second hypothesis that the link between lending and capital during expansions is stronger in the case of privately-held banks. However, our results in this respect are ambiguous because we do not find such an effect for privately-held banks reporting consolidated data. Such a result in this subsample may be attributed to a greater diversity of risks in privately-held banks reporting consolidated data. In contrast, banks reporting unconsolidated data (e.g. cooperatives) conduct their business locally, with idiosyncratic risks relatively more concentrated.

Columns 3 and 4 in Table 4 present results of our test of hypothesis 3. As we can see, the coefficient on Downturn*CAP is negative and statistically insignificant, which supports the view that lending of privately-held banks is not constrained by the capital ratio in economic downturns. Such results are found in both unconsolidated and consolidated data.

The robustness check of our estimations is presented in Table 5. As can be inferred from this table, the significant reduction of the number of instruments related to endogenous bank-specific variables affecting loan growth does not diminish the empirical importance of results presented in Table 4. These results are further supported because the regression coefficients on CAP and Downturn*CAP in all subsamples of banks are similar to those obtained in Table 4.

Additionally, our results support the phenomenon of conditional conservatism in loan loss accounting. As can be inferred from Table 4 and Table 5, the regression coefficient measuring the association between loan growth and QLP is definitely more negative (and statistically significant in the case of unconsolidated data) for publicly-traded banks than for privately-held banks, consistent with the view that privately-held banks create higher (and more timely) net total loan loss provisions when the loan growth is high. 
Ta b l e 4. The empirical results - unconsolidated versus consolidated data

\begin{tabular}{|c|c|c|c|c|c|c|c|c|}
\hline & \multicolumn{4}{|c|}{ Unconsolidated } & \multicolumn{4}{|c|}{ Consolidated } \\
\hline & \multicolumn{2}{|c|}{ pub.-traded } & \multicolumn{2}{|c|}{ priv.-held } & \multicolumn{2}{|c|}{ pub.-traded } & \multicolumn{2}{|c|}{ priv.-held } \\
\hline & 1 & p-value & 2 & p-value & 3 & $p$-value & 4 & $p$-value \\
\hline \multirow{2}{*}{$\Delta \operatorname{loan}(-1)$} & 0.155 & \multirow{2}{*}{0.04} & -0.077 & \multirow{2}{*}{0.00} & -0.010 & \multirow{2}{*}{0.52} & -0.067 & \multirow{2}{*}{0.14} \\
\hline & $(2.02)$ & & $(-3.48)$ & & $(-0.65)$ & & $(-1.49)$ & \\
\hline \multirow{2}{*}{$\Delta \operatorname{loan}(-2)$} & 0.032 & \multirow{2}{*}{0.49} & -0.082 & \multirow{2}{*}{0.00} & -0.061 & \multirow{2}{*}{0.00} & 0.122 & \multirow{2}{*}{0.00} \\
\hline & $(0.7)$ & & $(-3.35)$ & & $(-2.99)$ & & $(4.08)$ & \\
\hline \multirow{2}{*}{ Downturn } & -0.841 & \multirow{2}{*}{0.72} & -1.663 & \multirow{2}{*}{0.00} & -1.333 & \multirow{2}{*}{0.69} & -1.586 & \multirow{2}{*}{0.49} \\
\hline & $(-0.36)$ & & $(-3.46)$ & & $(-0.4)$ & & $(-0.69)$ & \\
\hline \multirow{2}{*}{ CAP } & 0.043 & \multirow{2}{*}{0.80} & 0.366 & \multirow{2}{*}{0.00} & -0.100 & \multirow{2}{*}{0.85} & -0.374 & \multirow{2}{*}{0.15} \\
\hline & $(0.25)$ & & (4.47) & & $(-0.19)$ & & $(-1.45)$ & \\
\hline \multirow{2}{*}{ Downturn*CAP } & 0.265 & \multirow{2}{*}{0.04} & -0.045 & \multirow{2}{*}{0.47} & 0.365 & \multirow{2}{*}{0.50} & -0.006 & \\
\hline & $(2.06)$ & & $(-0.73)$ & & $(0.67)$ & & $(-0.04)$ & 0.97 \\
\hline & 0.009 & & 0.002 & & 0.010 & & 0.003 & \\
\hline LIQUAP & $(2.55)$ & 0.01 & $(0.64)$ & 0.52 & $(0.8)$ & 0.43 & $(2.33)$ & 0.02 \\
\hline & 0.262 & 010 & -0.085 & & -0.053 & 010 & 0.022 & \\
\hline DEPBANKS & $(1.67)$ & 0.10 & $(-1.98)$ & 0.05 & $(-1.66)$ & 0.10 & $(0.41)$ & 0.68 \\
\hline & -1.798 & & -0.893 & & -0.069 & & -0.569 & \\
\hline$\triangle \mathrm{CAP}$ & $(-1.59)$ & 0.11 & $(-5.19)$ & 0.00 & $(-0.15)$ & 0.80 & $(-1.73)$ & 0.08 \\
\hline & -1.813 & & -0.583 & & -0.979 & & 4.824 & \\
\hline QLP & $(-2.74)$ & 0.01 & $(-2.72)$ & 0.01 & $(-0.42)$ & $0.0 /$ & (1.19) & 0.23 \\
\hline siz & -0.467 & 011 & 0.563 & 003 & 1.043 & 026 & 0.503 & 001 \\
\hline 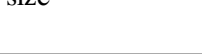 & $(-1.55)$ & 0.12 & (2.18) & 0.00 & $(0.92)$ & 0.00 & $(0.24)$ & 0.01 \\
\hline AUNC & -1.058 & 000 & 2.820 & 000 & -1.329 & 000 & -1.186 & 015 \\
\hline$\triangle \mathrm{UNEMIPL}$ & $(-3.14)$ & 0.00 & (13.13) & 0.00 & $(-4.62)$ & 0.00 & $(-1.42)$ & 0.15 \\
\hline Intor & 8.663 & 007 & -3.635 & 021 & -2.774 & 071 & 1.777 & 0.01 \\
\hline Intercept & (1.79) & 0.01 & $(-0.96)$ & 0.34 & $(-0.38)$ & 0.11 & $(0.11)$ & 0.91 \\
\hline ar1 & -3.62 & 0.00 & -3.82 & 0.00 & -1.31 & 0.19 & -2.48 & 0.01 \\
\hline ar2 & -0.93 & 0.35 & -3.25 & 0.00 & 0.09 & 0.93 & -1.41 & 0.16 \\
\hline
\end{tabular}


continued tab. 4

\begin{tabular}{|l|c|c|c|c|c|c|c|c|}
\hline & \multicolumn{4}{|c|}{ Unconsolidated } & \multicolumn{4}{c|}{ Consolidated } \\
\cline { 2 - 10 } & \multicolumn{2}{|c|}{ pub.-traded } & \multicolumn{2}{|c|}{ priv.-held } & \multicolumn{2}{c|}{ pub.-traded } & \multicolumn{2}{c|}{ priv.-held } \\
\cline { 2 - 10 } & $\mathbf{1}$ & $p$-value & $\mathbf{2}$ & $p$-value & $\mathbf{3}$ & $p$-value & $\mathbf{4}$ & $p$-value \\
\hline hansen & 107.45 & 1.00 & 1894.58 & 0.00 & 101.65 & 1.00 & 239.32 & 1.00 \\
\hline \# observations & 963 & & 19476 & & 1218 & & 2558 & \\
\hline \#banks & 113 & & 2197 & & 112 & & 245 & \\
\hline \#instruments & 444 & & 471 & & 454 & & 460 & \\
\hline
\end{tabular}

The model is given by equation (1). The symbols have the following meanings: $\Delta$ loan - annual loan growth rate; Downturn - Dummy equal to one in Downturns and 0 otherwise; CAP - capital ratio, i.e. equity capital to total assets; Downturn*CAP - Interaction between Downturn and capital ratio (CAP); $\triangle \mathrm{CAP}$ - annual change in capital ratio; DEPBANKS - Deposits from banks to total assets; LIQGAP - Loans less Total customer deposits less Deposits from banks divided by Loans; size - logarithm of total assets; QLP - Loan loss provisions divided by average loans; $\triangle$ UNEMPL - change in annual unemployment rate. \# - denotes the number of observations, banks and instruments. T-statistics are given in brackets. Data range 1996-2011.

Ta b l e 5. Robustness check - sensitivity of results to reduced number of instruments

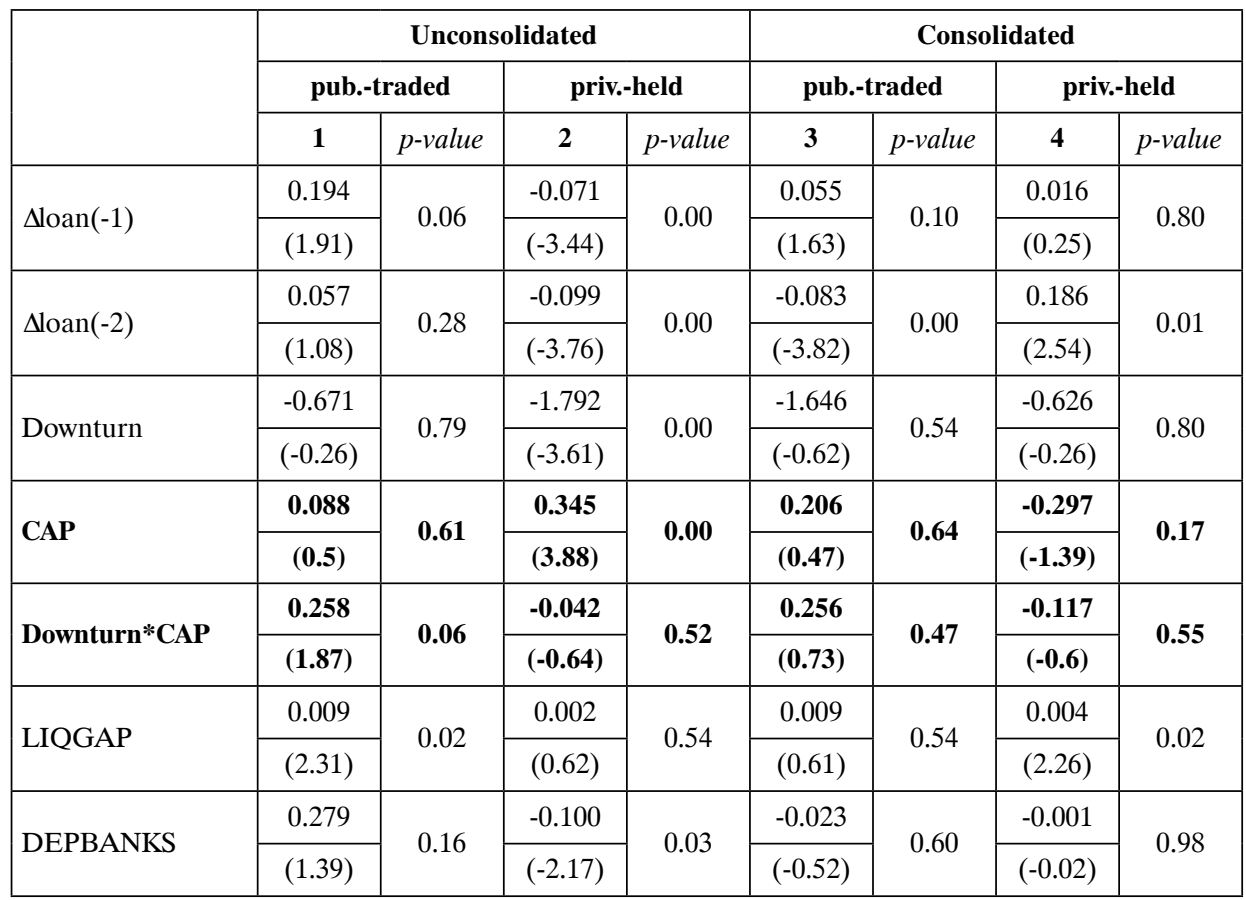


continued tab. 5

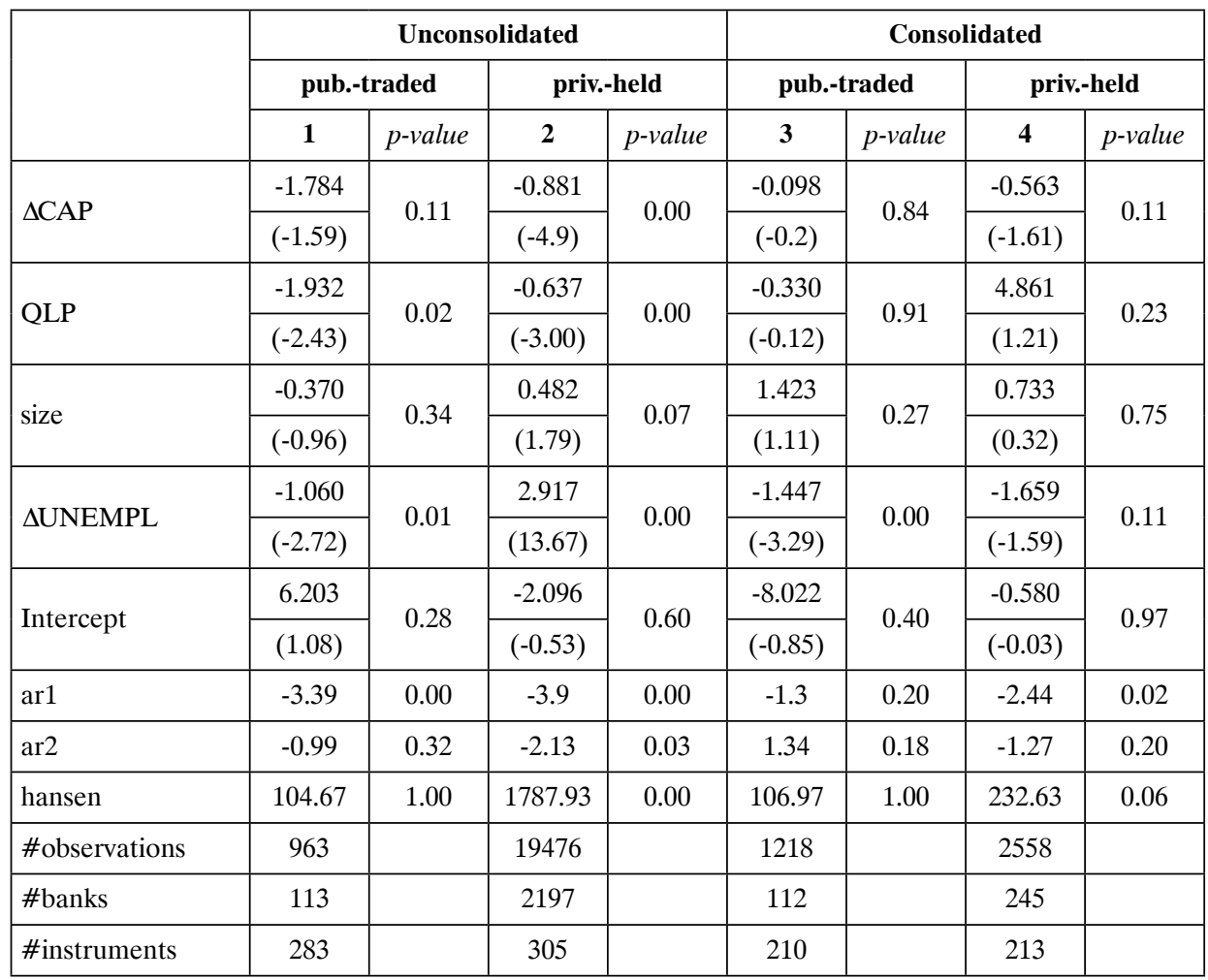

The model is given by equation (1). The symbols have the following meanings: $\Delta$ loan - annual loan growth rate; Downturn - Dummy equal to one in Downturns and 0 otherwise; CAP - capital ratio, i.e. equity capital to total assets; Downturn*CAP - Interaction between Downturn and capital ratio (CAP); $\triangle \mathrm{CAP}$ - annual change in capital ratio; DEPBANKS - Deposits from banks to total assets; LIQGAP - Loans less Total customer deposits less Deposits from banks divided by Loans; size - logarithm of total assets; QLP - Loan loss provisions divided by average loans; $\triangle \mathrm{UNEMPL} \mathrm{-} \mathrm{change} \mathrm{in} \mathrm{annual}$ unemployment rate. \# - denotes the number of observations, banks and instruments. T-statistics are given in brackets. Data range 1996-2011.

\section{Conclusions}

In this paper, we test two sets of predictions about how public versus private ownership drives differences in the link between lending and capital. In the first set, we predict that publicly-traded banks are more capitalconstrained during economic downturns than privately-held banks, which may be attributed to excessive risk-taking of publicly-traded banks in economic expansions and to conditional accounting conservatism. In the second set, we predict that privately-held banks are more capital-constrained in expansions 
- due to limited access to liquid equity capital markets. The lending of these banks will be less constrained by capital in economic downturns because of the importance of relationship banking and irrelevance of access to the equity capital market.

Our research shows that the link between lending and capital in economic downturns is stronger in publicly-traded banks than in privately-held banks. Additionally, the link between lending and capital during expansions is stronger in the case of privately-held banks reporting unconsolidated data, but not for banks reporting consolidated financial reports. Finally, we find empirical support for the view that lending of privately-held banks is not constrained by the capital ratio in economic downturns. Such results are found in both unconsolidated and consolidated data.

The results of our study have implications for the current regulatory challenges, in particular those related to the macroprudential policy. It seems vital that bank standard setters consider the role of the capital ownership structure in the process of deciding on the levels of countercyclical capital buffers defined in Basel III. In particular, publicly-traded banks, due to a greater sensitivity of loan growth to capital ratios in economic downturns should be recommended to keep higher capital buffers in economic booms. These buffers could be used in downturns to stimulate lending extension, which is necessary to boost the weakened economic growth.

\section{Acknowledgements}

We gratefully acknowledge the financial support provided by the National Science Centre (NCN), no. of decision DEC-2012/05/D/HS4/01356. These results have been presented at the Future of Finance Conference at the University of Lodz in 2015. The authors are grateful to Monika Marcinkowska and Joanna Stawska for their helpful comments and suggestions. This paper's findings, interpretations and conclusions are entirely those of the authors and do not necessarily represent the views of institutions with which the authors are affiliated.

\section{Bibliography}

Basel Committee on Banking Supervision (BCBS). (2011). Basel III: A global regulatory framework for more resilient banks and banking systems. Basel: Bank for International Settlements.

Ang, J., Cole, R. and Lin, J. (2000). Agency costs and ownership structure. Journal of Finance, 55, 81-106. 
Ball, R. and Shivakumar, L. (2005). Earnings quality in UK private firms: Comparative loss recognition timeliness. Journal of Accounting and Economics, 39(1), 83-128.

Bank for International Settlements (BIS), Financial Stability Board (FSB), International Monetary Fund (IMF). (2011). Macroprudential policy tools and frameworks. Progress report to G20, 27 October 2011.

Basel Committee on Banking Supervision (BCBS). (2011). Basel III: A global regulatory framework for more resilient banks and banking systems. Basel: Bank for International Settlements.

Basu, S. (1997). The conservatism principle and the asymmetric timeliness of earnings. Journal of Accounting \& Economics, 24(1), 3-37.

Beatty, A. and Liao, S. (2011). Do delays in expected loss recognition affect banks willingness to lend? Journal of Accounting and Economics, 52, 1-20.

Beatty, A. and Liao, S. (2014). Financial accounting in the banking industry: A review of the empirical literature. Journal of Accounting and Economics, 58, 339-383.

Beatty, A., Ke, B. and Petroni, K. (2002). Earnings management to avoid earnings declines across publicly and privately held banks. The Accounting Review, 77(3), 547-570.

Beaver, W. and Ryan, S. (2005). Conditional and unconditional conservatism: Concepts and modeling. The Review of Accounting Studies, 10(2/3), 269-309.

Berger, A.N. and Udell, G.F. (1994). Did risk-based capital allocate bank credit and cause a "credit crunch" in the United States? Journal of Money, Credit and Banking, 26(3), 585-628.

Berrospide, J.M. and Edge, R.M. (2010). The effects of bank capital on lending: What do we know? And what does it mean? International Journal of Central Banking, December 2010, 5-54.

Bliss, J.H. (1924). Management through accounts. New York, NY: the Ronald Press Co.

Blundell, R. and Bond, S. (1998). Initial conditions and moment restrictions in dynamic panel data model. Journal of Econometrics, 87, 115-143.

Borio, C. and Zhu, V.H. (2012). Capital regulation, risk-taking, and monetary policy: A missing link in the transmission mechanism? Journal of Financial Stability, 8, 236-251.

Bridges, J., Gregory, D., Nielsen, M., Pezzini, S., Radia, A., Spaltro, M. (2014). The impact of capital requirements on bank lending (Working Paper No. 486), Bank of England.

Carlson, M., Shan, H. and Warusawitharana, M. (2013). Capital ratios and bank lending: A matched bank approach. Journal of Financial Intermediation, 22, 663-687.

Claessens, S. (2014). An overview of macroprudential policy tools (IMF Working Paper No. WP/14/214).

Claessens, S., Ghosh, S.R. and Mihet, R. (2014). Macro-prudential policies to mitigate financial system vulnerabilities (IMF Working Paper WP/14/155).

Demski, J. (2003). Endogenous expectations. The Accounting Review, 79(2), 519-539.

Directive 2013/36/EU of the European Parliament and of the Council of 26 June 2013 on access to the activity of credit institutions and the prudential supervision of credit institutions and investment firms, amending Directive 2002/87/EC and repealing Directives 2006/48/EC and 2006/49/EC (CRDIV) [2013] OJ L176.

Fonseca, A.R. and González, F. (2008). Cross-country determinants of bank income smoothing by managing loan-loss provisions. Journal of Banking and Finance, 32, 217-228.

Fonseca, A.R. and González, F. (2010). How bank capital buffers vary across countries: The influence of cost of deposits, market power and bank regulation. Journal of Banking and Finance, 34, 892-902. 
Franses, P.H. and Dijk, D. (2005). The forecasting performance of various models for seasonality and nonlinearity for quarterly industrial production. International Journal of Forecasting, 21, 87-102.

Gambacorta, L. and Marqués-Ibáñez, D. (2011). The bank lending channel. Lessons from the crisis (Working Paper Series No. 1335/May 2011), European Central Bank.

International Monetary Fund (IMF). (2011). Macroprudential policy: An organizing framework. Paper prepared by the Monetary and Capital Markets Department, International Monetary Fund.

International Monetary Fund (IMF). (2014). Global financial stability report. Risk-taking, liquidity, and shadow banking. Curbing excess while promoting growth.

Jensen, M. and Meckling, W. (1976). Theory of the firm: Managerial behavior, agency costs and ownership structure. Journal of Financial Economics, 3, 305-360.

Labonne, C. and Lame, G. (2014). Credit growth and bank capital requirements: Binding or not? (Working Paper).

Lenart, Ł. and Pipień, M. (2013). Almost periodically correlated time series in business fluctuations analysis. Acta Physica Polonica A, 123(3), 70-86.

Merton, R.C. (1974). On the pricing of corporate debt: the risk structure of interest rates. Journal of Finance, 29, 449-70.

Mora, N. and Logan, A. (2012). Shock to bank capital: Evidence from UK banks at home and away. Applied Economics, 44(9), 1103-1119.

Myers, S. and Majluf, N. (1984). Corporate financing and investment decisions when firms have information that investors do not have. Journal of Financial Economics, 13, 187-221.

Nichols, D.C., Wahlen, J.M., Wieland, M.W. (2009). Publicly-traded versus privately held: implications for conditional conservatism in bank accounting. Review of Accounting Studies, 14, 88-122.

Olszak, M., Pipień, M., Roszkowska, S. and Kowalska, I. (2014). The effects of capital on bank lending of large EU Banks? - The role of procyclicality, income smoothing, regulations and supervision (Faculty of Management Working Paper Series 5/2014). Retrieved from: papers.ssrn.com/sol3/papers.cfm?abstract_id=2543675.

Parzen, E. and Pagano, M. (1979). An approach to modeling sezonally stationary time-series. Journal of Econometrics, 9, 137-153.

Peek, J. and Rosengren, E. (1995). The capital crunch: Neither a borrower nor a lender be. Journal of Money, Credit, and Banking, 27, 625-638.

Regulation (EU) No 575/2013 of the European Parliament and of the Council of 26 June 2013 on prudential requirements for credit institutions and investment firms and amending Regulation (EU) No 648/2012 (CRR) [2013] L 176.

Resti, A. and Sironi, A. (2007). Risk management and shareholders' value in banking. John Wiley and Sons Ltd.

Roberts, M.R. and Whited, T.M. (2011). Endogeneity in empirical corporate finance (Working Paper No. FR 11-29), The Bradley Policy Research Center, Financial Research and Policy, University of Rochester.

Roodman, D. (2009). Practitioners corner: A note on the theme of too many instruments. Oxford Bulletin of Economics and Statistics, 71, 135-156.

Stultz, R.M. (2014). Governance, risk management, and risk-taking in banks (Working Paper 20274), National Bureau of Economic Research, Massachusetts.

Wagster, J.D. (1999): The Basle Accord of 1988 and the international credit crunch of 1989-1992. Journal of Financial Services Research, 15, 123-143. 
Watts, R. (2003). Conservatism in accounting part I: Explanations and implications. Accounting Horizons, 17(3), 207-227.

Windmeijer, F. (2005). A finite sample correction for the variance of linear efficient two step GMM estimators. Journal of Econometrics, 126(1), 25-51. 



\title{
Rozdział III
}

\author{
JERZY ZEMKE*
}

\section{Zarządzanie w warunkach ryzyka kredytu hipotecznego indeksowanego walutą obcą}

Zarządzanie ryzykiem kredytów hipotecznych indeksowanych walutą obcą wymaga dostosowań zgodności strumieni odsetek walutowych i złotowych w celu zagwarantowania użycia depozytów złotowych dla zabezpieczenia kredytów w walucie obcej. Problem ten rozwiązywał kontrakt FX SWAP łącznie z transakcją CIRS, gwarantującą refundację różnicy dochodu z tytułu "użyczenia" waluty indeksacji opartej na stawce LIBOR i dochodu z tytułu odsetek od depozytu stanowiącego zabezpieczenie "użyczenia” opartego na stawce WIBOR. Kontrakty FX SWAP i CIRS zapewniały wysoką jakość zabezpieczeń banków przed skutkami ryzyka wzrostu kursu walutowego. Czy dostęp do takich instrumentów zabezpieczeń przed skutkami ryzyka wzrostu kursu waluty indeksacji miał kredytobiorca? W celu sformułowania odpowiedzi w pracy opisano mechanizm zmian standingu kredytu w warunkach wzrostu kursu walutowego. Wnioski będące wynikiem analizy tego mechanizmu, w połączeniu z dostępnymi na rynku instrumentami zabezpieczeń wskazują na brak symetrii ochrony przed skutkami ryzyka banku i kredytobiorcy.

Słowa kluczowe: kredyt w PLN indeksowany walutą obcą, ryzyko kredytu indeksowanego, zarządzania w warunkach ryzyka wzrostu kursu waluty indeksacji.

\section{Managing Under Risk of Loans Indexed to A Foreign Currency}

Managing the risk of mortgage loans indexed to a foreign currency required matching the flows of interest on foreign currencies and on Polish zloty, so as to ensure that deposits in PLN were used to collateralize foreign currency loans. This problem was solved by FX SWAP contracts. A SWAP contract is supplemented with a CIRS transaction, to guarantee the refund of the difference in income from "affording" the indexation currency based on LIBOR and income from interest on

dr hab. Jerzy Zemke - Uniwersytet Gdański, Wydział Zarządzania, Katedra Ekonometrii, ul. Armii Krajowej 101, 81-824 Sopot; e-mail: jerzy.zemke@ug.edu.pl 
deposit being used as a collateral based on WIBOR. FX SWAP and CIRS contracts ensured high quality of banks' hedge against consequences of potential exchange rate growth. Did borrowers have access to such instruments of protection against the risk of the indexation currency exchange rate growth? In order to answer this question, the study describes the mechanism of changes in the loan standing under the currency rate growth. The conclusions from the analysis of this mechanism, combined with the security instruments available on the market indicate clearly that there has been no symmetry in protection against the consequences of risk faced by the bank and the borrower.

Keywords: loan in PLN indexed to a foreign currency, indexed loan risk, managing under risk of the indexation currency rate growth.

JEL: G21, G28

\section{Wprowadzenie}

Przesłanki oferty kredytów hipotecznych indeksowanych walutą obcą wywodziły się z dwóch źródeł - z wysokich stóp procentowych i z aspiracji społeczeństwa polskiego do zaspokajania potrzeb mieszkaniowych. Zmiany ustrojowe zapoczątkowane w 1989 roku rozbudziły aspiracje społeczne, lecz nie łączyły się z wystarczającymi własnymi zasobami kapitałowymi. Możliwości ich zaspokojenia ułatwiał kredyt. Przy wysokim poziomie stóp procentowych koszt kredytu finansującego zakup mieszkania sięgał 20\% w skali roku. W lipcu 2002 roku Sejm Rzeczpospolitej Polski przyjął ustawę - Prawo dewizowe. Zapisy prawa umożliwiały zaś udzielanie tanich kredytów denominowanych ${ }^{1}$. Przystąpienie w maju 2004 roku Polski do Unii Europejskiej zdynamizowało rozwój gospodarczy, a decyzje o wprowadzeniu produktu denominowanego na rynek wzmacniała perspektywa włączenia polskiego systemu finansowego do strefy euro. Tak kreślona przyszłość dawała gwarancje spłaty zobowiązań kredytowych w walucie przychodów kredytobiorców w przyszłości. Nowa sytuacja polityczna Polski spowodowała uzupełnienie dotychczasowej oferty produktów kredytowych. Obok kredytu denominowanego, banki poszerzyły ofertę o kredyt indeksowany waluta obcą. Co różni obydwa produkty? Kredyt denominowany w walucie obcej udzielany jest w walucie obcej, wypłata natomiast realizowana jest $\mathrm{w}$ walucie polskiej według obowiązującego kurs z dnia wypłaty. Kredyt indeksowany walutą obcą był udzielony w walucie polskiej. Umowa kredytu indeksowanego walutą obcą określała kwotę kredytu w walu-

1 Ustawa z dnia 27 lipca 2002 r. - Prawo dewizowe (Dz.U. $2002 \mathrm{Nr} 141$ poz. 1178). 
cie polskiej oraz kwotę kredytu przewalutowanego według bankowego kursu kupna waluty indeksacji z dnia podpisania umowy2.

Bank jest instytucją finansową, statutowo handlującą pieniędzmi i nie są to pieniądze własne banku, pozyskiwane są one bowiem po jednostkowych cenach niższych aniżeli cena jednostkowa sprzedaży. Bank kreuje pieniądz oparty na wkładzie pierwotnym poprzez tworzenie wkładu pochodnego z puli kredytów udzielonych z tej części wkładu pierwotnego, która nie stanowi rezerwy obowiązkowej ${ }^{3}$. Tak księgowo tworzona pula środków pieniężnych przekształcana jest w pieniądz rzeczywisty w wyniku spłat kapitału przez kredytobiorców.

Mechanizm kreacji pieniądza umożliwiał bankom udzielanie kredytów indeksowanych walutą obcą, pomimo jej braku (Millenium Bank SA, 2005). Problem, który banki musiały rozwiązać dotyczył zgodności przychodu odsetkowego z tytułu udzielenia kredytów indeksowanych walutą obcą na bazie LIBOR z kosztem finansowania pozycji określonej oprocentowaniem depozytów w walucie polskiej na bazie WIBOR.

Banki udzielały kredytów w walucie polskiej, przewalutowanych według kursu walutowego $\mathrm{z}$ dnia podpisania umowy kredytowej i księgowały w walucie indeksacji, a kredytobiorcy przejmowali rolę beneficjentów transakcji finansowych FX SWAP i CIRS dokonywanych przez banki, ponieważ transakcje te gwarantowały bankom zgodność strumieni odsetek z tytułu przychodu oraz kosztów 4 .

Spłaty kredytu indeksowanego walutą obcą realizowane są w warunkach niepewności powodowanej zmiennością kursu walutowego. Miarą stanu nie-

2 Ostatecznym zobowiązaniem kredytobiorcy była kwota kredytu w walucie indeksacji przeliczonego według kursu kupna z dnia uruchomienia kredytu.

3 Kreowanie pieniądza to proces wprowadzania do obiegu przez banki dodatkowych ilości pieniądza. Proces ten prowadzi do powstania nowych zasobów pieniężnych. Kreacja pieniądza oparta jest na założeniu, że banki nie muszą przetrzymywać całości wpłaconych przez ich klientów wkładów. W celu ograniczenia ryzyka niewypłacalności banków i zwiększenia zaufania do całego systemu bank centralny wyznacza stopę rezerw obowiązkowych, określającą minimalny stosunek rezerw do wkładów. Resztę środków banki mogą przeznaczyć na udzielanie kredytu przedsiębiorstwom lub indywidualnym osobom. Sumy uzyskane dzięki akcji kredytowej są ponownie wpłacane na rachunki bankowe, przez co mogą służyć do udzielania dalszych pożyczek (zob. Grzywacz, 2002, s. 123 i nast.).

4 SWAP walutowy ( $F X S W A P)$ - jest umową dwóch podmiotów, dotyczącą wymiany na określony czas między sobą pewnej kwoty waluty na równowartość w innej walucie. Kurs wymiany powrotnej jest ustalany przy zawieraniu transakcji, w oparciu o różnicę oprocentowania tych walut. FX SWAP jest kontraktem na zakupu waluty w określonym dniu, po określonym kursie, a następnie odsprzedażą tej samej kwoty waluty po kursie i w terminie ustalonym w dniu zawarcia umowy. Zazwyczaj SWAP walutowy jest transakcją krótkoterminową, by ograniczyć koszty transakcji, banki zawierały umowy odnawialne jednodniowe (zob. Jajuga i Jajuga, 2006, s. 314-328). 
pewności realizacji spłat kredytu jest ryzyko kursu waluty indeksacji (Zemke, 2015). Celem pracy jest diagnoza zmian stanu funkcjonowania w warunkach ryzyka kursowego. Wymaga to nakreślenia scenariusza zmian zdolności od obsługi spłat kredytu, definicji i pomiaru ryzyka stanu niepewności wynikającego ze wzrostu kursu waluty indeksacji oraz wskazania skutecznych i efektywnych instrumentów ochrony podmiotów umowy kredytowej przed skutkami ryzyka.

Ry s u n e $\mathrm{k}$. Liczba udzielonych kredytów w walucie polskiej oraz kredytów walutowych w tym w CHF, EUR oraz pozostałe walutowe (w tys.) od 2004 do 2014 roku
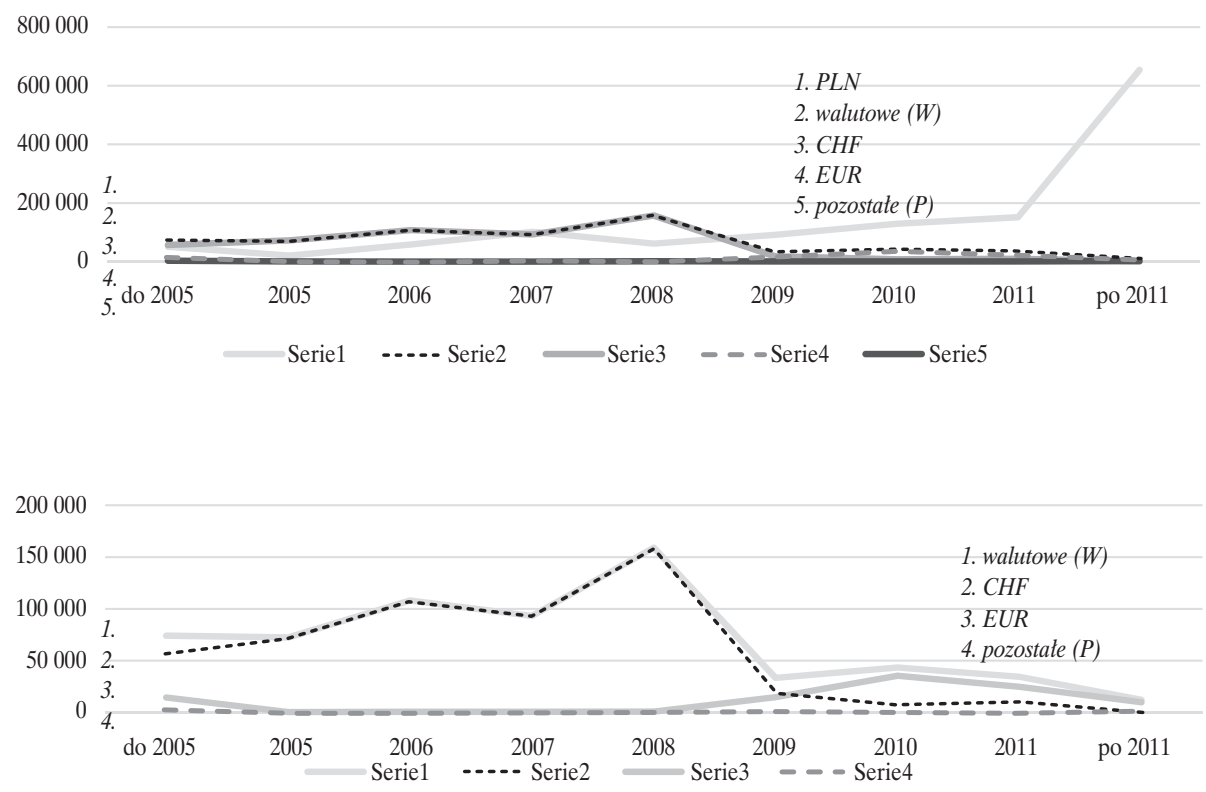

Źródło: opracowanie własne na podstawie danych z: KNF, 2015.

Kryzys na rynkach finansowych, rozwijający się od drugiej połowy 2008 roku, ujawnił skutki ryzyka produktu indeksowanego walutą obcą. Wzrost kursu waluty polskiej/waluty indeksacji powodował wzrost kosztów obsługi zobowiązań kredytobiorców, co oznaczało postępujący proces utraty płynności finansowej części kredytobiorców.

Od 2008 r. sprzedaż tego produktu została znacząco ograniczona (zob. rys. 1). Dotychczasowa tendencja sprzedaży kredytów hipotecznych zmieniła kierunek, powodem zaś stał się rosnący kurs walut indeksacji, głównie franka szwajcarskiego oraz zmiana dotychczasowych zasad udzielania kredy- 
tów hipotecznych indeksowanych walutą obcą po wprowadzeniu w roku 2013 Rekomendacji S. Zmiany pogłębiły wątpliwości głównie kredytobiorców, co do jakości zabezpieczenia przed skutkami głównie wzrostu kursu walut indeksacji. Jednocześnie wzrost kursów walut indeksacji zidentyfikował kredytobiorców, którzy tracili płynność w miarę wzrostu kursu walutowego. Sytuacja ta ujawniła fakt, że kredytobiorcy nie dysponują skutecznymi instrumentami ochrony przed wzrostem kosztów obsługi kredytu oraz indeksacją kapitału kredytowego, co definiuje tezę pracy5:

Nie ma dostęnych skutecznych i efektywnych instrumentów zarządzania $w$ warunkach ryzyka kredytu hipotecznego indeksowanego waluta obca spowodowanego wzrostem kursu indeksacji, które chroniq kredytobiorcę. Skuteczne i efektywne instrumenty chronia przed skutkami ryzyka wzrostu kursu walutowego banki.

Tendencja wzrostu kursu waluty polskiej/waluty indeksacji w okresie spłat należnego kapitału kredytowego, zmienia wskaźnik $D t I$ oraz $L t V$ :

$$
D t I=\frac{R+Z_{p f}}{D} 100 \%, \quad L t V=\frac{K}{W z} 100 \%,
$$

gdzie:

$R$ - rata kredytu,

$K$ - kwota kredytu,

$D$ - kwota miesięcznego dochodu,

$Z_{p f}$ - pozostałe zobowiązania finansowe,

$W z$ - wartość zabezpieczenia kredytu 6 .

Indeksacja kapitału kredytowego powoduje wzrost salda kapitału pozostającego do spłaty. W rezultacie bieżąca wartość wskaźnika DtI, określająca relację sumy zobowiązań finansowych do dochodu, wykazuje tendencję wzrostu, przyjmując wartość większą od wartości dopuszczalnej $D t I^{(0)}$, oszacowanej

5 Na koniec 2014 roku czynnych było 1,862 mln kredytów hipotecznych (65\% kredytów ogółem), w tym 654, 4 tys., to kredyty walutowe (35\% liczy kredytów ogółem). Struktura kredytów walutowych: 542,9 tys., w CHF, 106,0 tys. w EUR, 5,5 tys. inne waluty. Łączna wartość udzielonych kredytów 346,769 mld zł, w tym 183,855 mld zł kredyty zlotowe (53\% wartości łącznej kredytów), 162,914 mld zł kredyty walutowe (47\% wartości udzielonych kredytów) (zob. KNF, 2015).

6 Wskaźnik DtI (Debt to income), wskaźnik zdolności kredytowej. LtV (Loan to value), współczynnik kwoty kredytu, do wartości zabezpieczenia (zwykle hipotecznego) kredytu. 
w momencie podjęcia decyzji kredytowej ${ }^{7}$. Podobne niekorzystne zmiany wykazuje wskaźnik $L t V$. Wzrost salda indeksowanego kapitału, powoduje wzrost wskaźnika zabezpieczenia kredytu $L t V$ ponad wartość dopuszczalną $L t V^{(0) 8}$. Zmiana fundamentalnych dla decyzji kredytowych wskaźników $D t I$ oraz $L t V$ oznacza pojawienie się problemu bilansowego banku, a jego usunięcie wymaga dodatkowego zabezpieczenia kredytu.

\section{Monitoring obsługi kredytu}

Monitoring jest narzędziem pozyskiwania, przechowywania i przetwarzania danych gromadzonych w procesie bieżącego gromadzenia informacji o zmianach uwarunkowań mikro- i makrootoczenia kredytobiorcy (Dellmann, 1992, s. 134). Przetworzone dane stanowią podstawowy zbiór informacji o procesach planowania i kontroli zarządzania ryzykiem, wzmacniających nadzór nad spłatą zobowiązań. Nie bez znaczenia dla monitoringu i kontroli pozostaje funkcja eksploracyjna gromadzonej informacji. Umożliwia ona określenie przyczyn wahań stanu monitorowanego procesu (Dellmann, 1992, s. 131).

Monitoring kredytów zapewnia oczekiwaną jakość zarządzania strukturą oraz jakością portfela kredytowego. Z założenia jest systemem bieżącej weryfikacji zdolności kredytowej klienta w czasie realizacji umowy kredytowej. Monitoring w pełni charakteryzują dwie funkcje:

1) informacyjna, dotyczy całego portfela kredytowego i odnosi się do identyfikacji elementów składowych, stopnia dywersyfikacji oraz dynamiki i kierunku rozwoju akcji kredytowej;

2) zabezpieczająca, dotyczy działań gwarantujących bankom aktywną działalność kredytową (Grzywacz, 2002, s. 177).

Spłatę zadłużenia określają harmonogramy, które zawierają informacje o datach wpłat oraz kwocie wymaganej raty. Administracja obsługi kredytu konfrontuje zgodność terminów spłat oraz wysokość dokonywanych wpłat z zapisami harmonogramu. Informacja o zgodności spłat zobowiązań wobec

7 Według Komisji Nadzoru Finansowego (Rekomendacja $S$ z 2006 roku), wskaźnik akceptowalny $D t I=50 \%$ oznacza zdolność kredytową kredytobiorców osiągających dochody netto poniżej średniej krajowej, a dopuszczalna wartość wskaźnika $D t I=65 \%$ dotyczy kredytobiorców osiągających dochód netto powyżej średniej.

8 Już $L t V=100 \%$ oznacza, że wartość pożyczonego kapitału jest równa wartości zabezpieczenia. Na dzień 31.12.2013 r. 24,09\% kredytów indeksowanych w CHF wykazywało $L t V>100 \%$ (pobrano z: www.gospodarka.dziennik.pl (15.01.2015)). W przypadku wypowiedzenia umowy kredytowej, przejęcie zabezpieczenia i sprzedaż w „warunkach szybkiej sprzedaży”, nie przekracza 70\% wartości przyjętej do zabezpieczenia kredytu (zob. KNF, 2015). 
banku z harmonogramem spłat wypełnia z każdą kolejną spłatą kapitału oraz odsetek od pożyczonego kapitału „horyzont spłat” kredytu, a historia spłat zobowiązań umożliwia prognozę obsługi zadłużenia. Ta z kolei umożliwia ocenę jakości, dynamikę oraz kierunek działalności kredytowej banku w przyszłości, niezbędnej w procesie kreacji pieniądza.

\subsection{Kontrola standingu finansowego kredytobiorcy}

Akceptacja standingu finansowego kredytobiorcy jest wynikiem uznania za wiarygodne dane o dochodach netto, określających akceptowalną wartość wskaźnika $D t I$. Zapisy umów o konieczności aktualizacji dokumentów finansowych, informowania banku kredytującego o spadku przychodów, utracie pracy, chorobie, zgonie kredytobiorcy itp., są elementem zarządzania ryzykiem kredytowym. Obok wymienionych przypadków losowych, kredytobiorca zobowiązany jest do składania informacji rocznej o osiągniętych dochodach ${ }^{9}$. Informacja ta umożliwia instytucji finansowej ocenę stabilności finansowej kredytobiorcy.

Opóźnienia w terminowej spłacie zobowiązań bądź zaprzestaniu obsługi spłat zobowiązań są podstawą pozyskania istotnej kategorii informacji, określanej mianem eksploracyjnej. Jest ona nośnikiem wiedzy o przyczynach zaistniałej sytuacji. Informacja roczna o sytuacji finansowej kredytobiorcy jest informacją historyczną i nie jest gwarantem powtórzenia tej sytuacji w kolejnym roku.

\section{Ryzyko kredytów indeksowanych walutą obcą}

Rynek walutowy cechuje zmienność kursów walut. Zmiany kursu waluty polskiej w relacji do waluty indeksacji wpływają z jednej strony na zmiany stanu wierzytelności banków będących pochodną udzielonych kredytów hipotecznych indeksowanych waluta obca, z drugiej zaś - na sytuację finansową kredytobiorców. Niepewność, co do kierunku i dynamiki zmian kursu walutowego przy stałych dochodach powoduje wahania zdolności do obsługi zobowiązań z tytułu udzielonego kredytu hipotecznego indeksowanego waluta obcą.

Kredyt hipoteczny indeksowany walutą obcą natomiast:

1) jest kredytem długoterminowym, wypłacanym w walucie polskiej;

2) w momencie jego uruchomienia, kapitał kredytu przeliczany jest według kursu kupna waluty indeksacji;

3) jego harmonogram spłat określa raty kapitałowo-odsetkowe w walucie indeksacji;

9 Rozliczenie roczne z Urzędem Skarbowym, PIT. 
4) posiada oprocentowanie zmienne;

5) spłata zobowiązań możliwa w walucie polskiej jest zakupem waluty indeksacji według kursu sprzedaży dnia bądź alternatywnie w walucie indeksacji ${ }^{10}$.

Wartość udzielonych kredytów indeksowanych walutą obcą sprzed 2005, 2005 i dalej do 2009 roku wykazuje znaczącą dynamikę, liczona rok do roku przyjmuje wartości: 2005/sprzed 2005 - 192,42\%, 2006/2005 - 231,42\%, 2007/2006 - 136,78\%, 2008/2007 - 171,98\%, 2009/2008 - 17,71\%. Potencjalne skutki wzrostu kredytów hipotecznych indeksowanych walutą obcą dostrzegła Komisja Nadzoru Finansowego (KNF), w ocenie Komisji ich źródłem była masowość kredytów11. W marcu 2006 roku KNF skierowała do banków Rekomendację S, zalecając w przypadku szacowania zdolności kredytowej produktu indeksowanego walutą obcą, przyjąć dwa założenia:

1) informacyjne - dotyczy całego portfela kredytowego, identyfikacji jego struktury, stopnia dywersyfikacji oraz dynamiki i kierunku rozwoju akcji kredytowej;

2) oprocentowanie w wysokości analogicznej, jak dla kredytu w walucie krajowej, a kwotę kredytu walutowego zalecano zwiększyć o $20 \%$.

Zalecenia Rekomendacji S określały kwotę miesięcznej raty na poziomie $50 \%$ dochodów miesięcznych. Jeśli dochody kredytobiorcy nie przekraczały średniej krajowej i 65\% w przypadku dochodów wyższych od średniej, określała ona kwotę kredytu według algorytmu:

1) oprocentowanie analogiczne jak dla kredytu w walucie krajowej;

2) kwota kredytu walutowego powiększona o $20 \%$.

Sformalizowany opis zaleceń Rekomendacji przyjmie postać:

A. Reguła szacowania miesięcznej raty spłaty (kapitał + odsetki):

$$
R=\left\{\begin{array}{l}
0,5 \cdot N, N \leq S_{k} \\
0,65 \cdot N, N>S_{k}
\end{array}\right.
$$

10 W lipcu 2011 roku została uchwalona tzw. ustawa antyspreadowa. Wprowadza ona do prawa bankowego następujący zapis (art. 69 ust. 3): „W przypadku umowy o kredyt denominowany lub indeksowany do waluty innej niż waluta polska, kredytobiorca może dokonywać spłaty rat kapitałowo-odsetkowych oraz dokonać przedterminowej spłaty pełnej lub częściowej kwoty kredytu bezpośrednio w tej walucie. $\mathrm{W}$ tym przypadku w umowie o kredyt, określa się także zasady otwarcia i prowadzenia rachunku służącego do gromadzenia środków przeznaczonych na spłatę kredytu oraz zasady dokonywania spłaty za pośrednictwem tego rachunku".

11 Dane w Załączniku nr 1. opracowane na podstawie: KNF, 2015. 
gdzie:

$R$ - miesięczna rata spłaty (kapitał + odsetki),

$N$ - miesięczny dochód kredytobiorcy,

$S_{k}$ - średnia krajowa dochodu.

B. Reguła szacowania wysokości miesięcznej spłaty w modelu spłat równych rat $^{12}$ :

$$
R=\frac{K \cdot S}{1-(1+S)^{-n}}, \text { gdzie } S=\frac{s_{p} \cdot d}{L d_{r}},
$$

gdzie:

$K-$ kwota kredytu,

$R$ - miesięczna rata kredytu (kapitał + odsetki),

$d$ - odstęp pomiędzy datami spłat rat w dniach,

$L d_{r}$ - liczba dni w roku,

$n$ - liczba rat spłat kredytu,

$s_{p} \quad$ - oprocentowanie kredytu.

Z relacji (1) i (2) wynika: $K= \begin{cases}\frac{0,5 \cdot N \cdot\left(1-(1+S)^{-n}\right)}{S} ; & N \leq S_{k} \\ \frac{0,65 \cdot N \cdot\left(1-(1+S)^{-n}\right)}{S} ; & N>S_{k}\end{cases}$

Zalecenia Rekomendacji S określają kwotę kredytu $K$ wyznaczanej z relacji (2) z uwzględnieniem dopuszczalnej kwoty raty $R$ zgodnie z Rekomendacją $\mathrm{S}$ z 2006 roku.

Wobec kryzysu na rynkach finansowych, w połączeniu ze wzrostem kursów walut indeksacji, zalecenia Rekomendacji S z 2006 roku zostały skorygowane. Rekomendacja S Komisji Nadzoru Finansowego z 18 czerwca 2013 r. została przebudowana zgodnie z zaleceniami Rekomendacji $\mathrm{T}$, a główne zmiany to:

1) kredytowanie w walutach obcych - kredyty walutowe, indeksowane lub denominowane w walutach obcych oferowane są wyłącznie klientom mającym dochody w walucie kredytu;

2) ustalanie wskaźnika DtI pozostawiono zarządom banków, zalecając szczególną ostrożność w sytuacji, gdy wartość DtI przekracza $40 \%$ w przypadku

12 Na podstawie modelu równych rat kapitałowo-odsetkowych w okresie spłaty (zob. Podgórska i Klimkowska, 2013). 
klientów o dochodach nieprzekraczających przeciętnego poziomu dochodów w regionie zamieszkania i 50\% dla pozostałych klientów.

\section{Ry s u n e k2. Wartość kredytów pozostałych do spłaty [tys. zł] do 2014 roku}

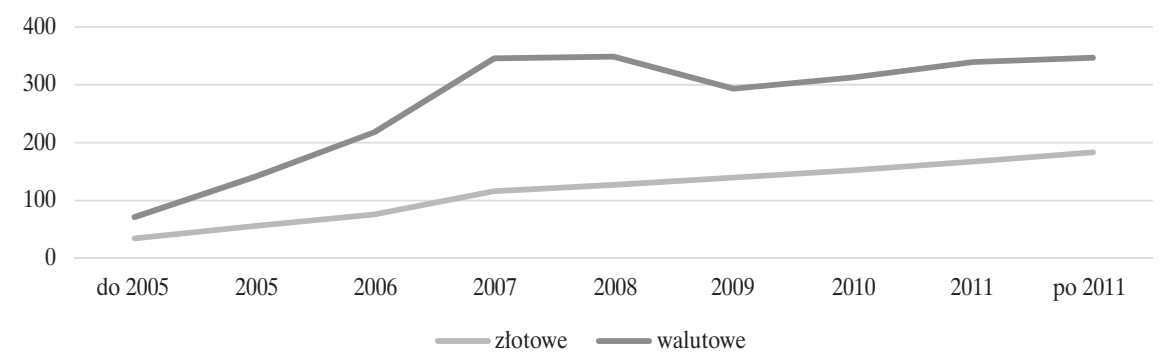

Źródło: opracowanie własne na podstawie danych z: KNF, 2015.

Przyjęte zalecenia Rekomendacji S z 2013 roku przyspieszyły proces redukcji skali udzielanych kredytów hipotecznych indeksowanych waluta obcą, ale po 2008 roku uwidocznił się problem spłat rat kredytowych, rosła wartość kredytów pozostałych do spłaty (zob. rys. 2), a jednocześnie powiększała się liczba kredytobiorców, którzy tracili płynność finansową bądź dokonywali spłat zobowiązań nieregularnie.

Rata spłaty jest sumą spłacanego kapitału oraz odsetek od salda zadłużenia. Indeksacja raty jest zatem równoważna indeksacji raty kapitałowej i odsetek:

$$
\text { indeks }(R)=\text { indeks }(K+O) ; \Rightarrow \text { indeks }(R)=\text { indeks }(K)+\text { indeks }(O) \text {, }
$$

gdzie:

indeks $(R)$, indeks $(K)$, indeks $(O)$ - indeksacja kursem walutowym: raty $R$, kapitału $K$, i odsetek $O$.

Zakładam wartość wskaźnika zdolności kredytowej $D t I^{(0)}$ oraz wskaźnika $L t V^{(0)}$ zabezpieczenia hipotecznego kredytu oszacowaną dla poziomu kursu waluty indeksacji „ $r$ ” w procesie oceny zdolności kredytowej - moment „0”. Przyjmując, że wzrost kursu o $p \%$ powoduje wzrost wskaźników $D t I^{(0)}$ i $L t V^{(0)}$ do poziomu $D t I^{(t)}, L t V^{(t)}$ oznacza „wejście” w obszar ryzyka spowodowanego wzrostem kursu waluty indeksacji.

„Definicja. Ryzyko kredytu indeksowanego, określa stan zdolności do obsługi zobowiązań, mierzonych wysokością rat miesięcznych spłat kredytu 
w momencie t, skutkiem, którego, wartość wskaźnika $D t I^{(t)}$ spełnia relację $D t I^{(t)}$ $>D t I^{(0)}$ lub utratę wypłacalności mierzoną wartością bieżącą wskaźnika zabezpieczenia $L t V^{(t)}$ spełniającą relację $L t V^{(t)}>L t V^{(0)}$ ".

Rekomendacje S, ta z roku 2006 i kolejna z 2013 roku zalecane przez Komisję Nadzoru Finansowego, określały graniczne, dopuszczalne wartości wskaźników $D t I$ oraz $L t V$. Przyjmując założenie, że poziom miesięcznego dochodu $D$ jest stabilny - nie ulega zmianie w okresie spłat kredytu, to w przypadku kredytów hipotecznych indeksowanych walutą obcą, wartości wskaźników DtI oraz $L t V$ są funkcją zmian kursu waluty indeksacji ${ }^{13}$.

Wartość wskaźnika $D t I$ w momencie „0”, gdy kurs waluty indeksacji ma wartość „r”:

$$
D t I^{(0)}=\frac{R+Z_{p f}}{D} 100 \%
$$

Wartość wskaźnika $D t I$ w momencie „t”, gdy kurs waluty indeksacji wzrasta $p \%$ powyżej poziomu kursu , $r$ " w momencie udzielenia kredytu:

$$
D t I^{(1)}=\frac{(1+p) R+Z_{p f}}{D} 100 \%,
$$

gdzie:

$D t I^{(0)}$ - wskaźnik zdolności kredytowej w momencie „0” - kurs waluty indeksacji , ,r”,

$D t I^{(t)}$ - wskaźnik zdolności kredytowej w momencie „t”, gdy kurs waluty indeksacji wzrasta 0 , $p$ ” w relacji do poziomu kursu , $r$,

$R \quad$ - miesięczna rata spłat kredytu w momencie udzielenia kredytu,

$Z_{p f} \quad$ - pozostałe miesięczne zobowiązania finansowe,

D - miesięczny dochód kredytobiorcy w momencie udzielenia kredytu,

zatem: $D t I^{(t)}=D t I^{(0)}+\frac{p \cdot R+Z_{p f}}{D} 100 \%$, jeśli $p>0$, to $\frac{p \cdot R+Z_{p f}}{D}>0$.

$$
D t I^{(t)}>D t I^{(0)}
$$

Bank, oceniając wypłacalności kredytobiorcy, szacuje wskaźnik zabezpieczenia kredytu $L t V^{(0)}$. W okresie spłat rat kredytowych mogą wystąpić dwa zdarzenia, które powodują wzrost wartość wskaźnika $L t V$. Pierwsze, łączy się ze

13 Zakładam, że pozostałe zobowiązania finansowe $Z_{p f}$ nie wzrastają. 
spadkiem wartości nieruchomości stanowiącej zabezpieczenie kredytu, drugie - wzrost zadłużenia wskutek wzrostu kursu waluty indeksacji.

Przy założeniu, że w momencie „t” kurs waluty indeksacji wzrósł o „p” w relacji do poziomu kursu „r” w momencie „0”, wskaźnik zabezpieczenia kredytu wyznacza relacja:

$$
L t V^{(0)}=\frac{K}{W z} 100 \%,
$$

$K$ - kwota kredytu pozostającego do spłaty, zatem:

$$
L t V^{(t)}=\frac{(1+p) K}{W z} 100 \%,
$$

gdzie:

$L t V^{(0)}$ - wskaźnik zabezpieczenia kredytu w momencie „0” - kurs waluty indeksacji , $r ”$,

$L t V^{(t)}$ - wskaźnik zabezpieczenia kredytu w momencie $t$, gdy kurs waluty indeksacji wzrasta o „p” w relacji do poziomu kursu , $r$,

$$
L t V^{(t)}=L t V^{(0)}(1+p), p>0, \text { stąd } L t V^{(t)}>L t V^{(0)} .
$$

Wzrost wartości wskaźnika $L t V$, podobnie jak w przypadku wzrostu wartości wskaźnika zdolności kredytowej $D t I$, jest miarą wzrostu ryzyka kredytowego. Obszar ryzyka wyznacza wartość wzrostu kursu waluty indeksacji „p”, który powoduje wzrost wskaźnika $D t I$ lub $L t V$ ponad poziom wartości zalecanych przez Komisję Nadzoru Finansowego określonych w Rekomendacji S z lat 2006 i 2013. Relacje (6) oraz (9) wyznaczają graniczne wartości wzrostu kursu waluty indeksacji „ $p$ ”. Niech zalecane w Rekomendacjach S wartości wskaźników zdolności kredytowej oraz zabezpieczenia kredytu odpowiednio równe $D t I^{(r)}$ oraz $L t V^{(r)}$,

stąd: $\quad D t I^{(t)}=\frac{(1+p) R+Z_{p f}}{D}>D t I^{(r)}, L t V^{(t)}=\frac{(1+p) K}{W z}>L t V^{(r)}$,

zatem: $\quad p>\frac{1}{R}\left(D \cdot D t I^{(r)}-\left(R+Z_{p f}\right)\right), p>\frac{W z}{K} L t V((r)-1)$. 
Wartość krytyczną wzrostu kursu waluty indeksacji wprowadzającą proces kredytowania w stan utraty zdolności kredytowej lub wypłacalności określa:

$$
\min \left[\frac{1}{R}\left(D \cdot D t I^{(r)}-\left(R+Z_{p f}\right)\right) ; \frac{W z}{K} L t V^{(r)}-1\right] .
$$

Zdefiniowana wartość kursu waluty indeksacji „p” powoduje wzrost w momencie „ $t$ ” wartości wskaźnika $D t I^{(t)}$ ponad rekomendowaną przez Komisję Nadzoru Finansowego wartość $D t I^{(r)}$ bądź wskaźnika $L t V^{(t)}$ ponad wartość zalecaną $L t V^{(r)}$, bądź też obydwu wskaźników jednocześnie.

\subsection{Zarządzanie w warunkach ryzyka kredytu indeksowanego walutą obcą}

Zarządzanie w warunkach ryzyka oparte jest na uniwersalnych założeniach regulacji ostrożnościowych i obejmuje regulacje zewnętrzne określone przez instytucje nadzorcze uzupełnione o regulacje wewnętrzne instytucji finansowych (Grzywacz, 2002, s. 211):

1) regulacje zewnętrzne: limity koncentracji kredytów, rezerwy celowe, poziom wypłacalności banku;

2) regulacje wewnętrzne: tworzenie funduszy ryzyka, ograniczenia branżowe przy udzielaniu kredytów.

Procesy zarządzania prowadzone są wobec zarówno pojedynczych kredytów, jak i całego portfela kredytowego.

W przypadku pojedynczych kredytów zarządzanie w warunkach ryzyka kładzie nacisk na:

1) rozwój metod oceny wiarygodności kredytowej kredytobiorcy;

2) wprowadzenie i przestrzeganie limitów ograniczających wartość udzielanych kredytów;

3) zabezpieczanie udzielonych kredytów aktywami o dużej płynności;

4) bieżącą ocenę zdolności kredytowej w procesie monitoringu spłat kredytu.

Założenia systemu zarządzania mechanizmami redukcji skutków ryzyka mają jednoznacznie określone miejsce w czasie. Postrzegane są jako działania ex ante oraz ex post.

Mechanizmy ex ante funkcjonują od momentu rozpoczęcia udzielania kredytów hipotecznych indeksowanych walutą obcą. W 2004 roku nie wszystkie banki dysponowały własnymi zasobami walut indeksacji, zatem przygotowanie sprzedaży tego produktu wymagało zabezpieczenia przed skutkami ryzyka walutowego, źródłem którego jest wzrost kursu waluty polskiej/waluty indeksa- 
$\mathrm{cji}^{14}$. Ochronę przed skutkami ryzyka walutowego gwarantował kontrakt realizowany w dwóch etapach:

1) początkowy przepływ zasobów pieniężnych - bank udzielający kredytów w walucie polskiej indeksowanych walutą obcą - pożyczkobiorca pożycza na rynku międzybankowym walutę indeksacji, zabezpieczeniem pożyczki są depozyt waluty polskiej pożyczkobiorcy w kwocie przeliczonej według kursu dnia transakcji równej pożyczonej kwocie waluty indeksacji;

2) końcowy przepływ zasobów pieniężnych - pożyczkobiorca zwraca pożyczkę w walucie indeksacji, a pożyczkodawca zwalnia zabezpieczenie - depozyt w walucie polskiej; banki rozliczają terminowe płatności odsetkowe, czyli pożyczkobiorca odsetki w walucie indeksacji wygenerowane w okresie realizacji kontraktu FX SWAP, a pożyczkodawca odsetki w walucie polskiej.

Idea kontraktu SWAP zakładała, że bank udzielający kredytów indeksowanych walutą obcą otrzymywał od innego banku walutę indeksacji, zabezpieczoną depozytem w walucie polskiej o wartości przeliczonej według waluty polskiej/waluty indeksacji z dnia zawarcia kontraktu (McDougall, 2001, s. 24-38).

Kontrakt FX SWAP generował różnice pomiędzy wygenerowanymi w terminie funkcjonowania kontraktu odsetkami od pożyczonej kwoty waluty indeksacji oraz depozytu w walucie polskiej stanowiącej zabezpieczenie pożyczki ${ }^{15}$. Koniecznym dopełnieniem kontraktu FX SWAP była transakcja CIRS gwarantująca refundację różnicy odsetek wygenerowanych przez pożyczkę $\mathrm{w}$ walucie indeksacji, a odsetkami od depozytu w walucie polskiej zabezpieczającego pożyczkę waluty indeksacji. Fundusz refundacji zasilany jest sukcesywnie w okresie spłat zobowiązań kredytowych. Zasób funduszu generowany jest zaś wzrostem kursu walutowego wspartym spread'em walutowym ustalanym przez bank ${ }^{16}$.

Łączne zaangażowanie kredytowe bank ma możliwość zabezpieczać poprzez:

1) różnicowanie portfela kredytowego - dywersyfikacja ryzyka;

14 Dowodzą tego sprawozdania finansowe banków z roku 2004 i następnych lat, które podjęły sprzedaż kredytów indeksowanych waluta obcą.

15 SWAP walutowy jest instrumentem bilansowym, doskonale wpisuje się w potrzeby banku w przypadku, gdy ten nie dysponuje walutą indeksacji. Zasady funkcjonowania SWAP (zob. Holliwell, 2001, s. 281-286).

16 Zarzadzanie ryzykiem z użyciem kontraktu FX SWAP oraz transakcji CIRS jest wysoce efektywne, nakłady są bowiem kosztami, a te przypadku wymienionych transakcji są minimalne. Dla oceny efektywności zarządzania ryzykiem K. Jajuga proponuje mierzyć relację nakładów do efektu (Czerwińska i Jajuga, 2016, s. 45). 
2) transfer ryzyka: ubezpieczenie przed skutkami ryzyka, sekurytyzacja kredytów, sprzedaż części portfela kredytowego, akredytywy gwarancyjne (Rose, 1997, s. 97).

Instrumentami łącznego zarządzania portfelem kredytów hipotecznych indeksowanych walutą obcą w warunkach wzrostu kursu walutowego są narzędzia kategorii ex post zwykle używane wobec tej części portfela, która jest w stanie wymagalności.

Sekurytyzacja aktywów przynoszących dochód, jakimi są kredyty hipoteczne, jest zbyciem papierów wartościowych zabezpieczonych na tego rodzaju aktywach. Strumień środków pieniężnych ze spłat zadłużenia kierowany jest do nabywców tych papierów wartościowych, co jest równoznaczne z zamianą kredytu bankowego na papiery wartościowe w obrocie publicznym. W rezultacie bank otrzymuje zwrotnie pieniądze z zawartych transakcji. Sekurytyzacja przekształca niepłynne kredyty w płynne aktywa (Rose, 1977, s. 87).

Papiery wartościowe, jako produkt sekurytyzacji kredytów hipotecznych, są zbliżone do obligacji o stałym oprocentowaniu płatnym w określonych okresach: miesięcznym, kwartalnym lub półrocznym. Założenie regularności płatności może wywoływać wrażenie niskiego ryzyka inwestycji, tak jednak nie jest. Źródłem ryzyka sekurytyzacji jest sytuacja, gdy część pożyczek nie jest spłacana, skutkiem takiej sytuacji jest zmniejszenie strumienia dochodów, co obniża stopę zwrotu inwestorów. Przeciwieństwem opóźnień w spłacie bądź zaprzestania spłat jest wcześniejsza spłata zobowiązań, co powiązane jest z ryzykiem przedwczesnej spłaty (prepayment risk). Źródłem takich decyzji kredytobiorców jest spadek stóp zwrotu. W takim przypadku ochrona inwestycji kapitałowej zmusza inwestora do reinwestycji, ale już w lokaty o niższej rynkowej stopie przychodu (Rose, 1977, s. 82-88).

Sprzedaż części bądź całości portfela kredytów hipotecznych (loan sales) o terminach zapadalności 90 dni i dłuższych łączona jest $\mathrm{z}$ gwarancją praw obsługi kredytu (servicing rights). Sprzedający administruje kredyt, pobiera odsetki oraz monitoruje zgodność spłat z zapisem umowy kredytowej. U podstaw decyzji sprzedaży portfela kredytowego leży zaufanie nabywcy aktywów do doświadczenia sprzedającego i jego wiarygodności ocen zdolności kredytowej. Ostatecznie decyzja, jaka i która część portfela kredytowego zostanie sprzedana jest wynikiem kompromisu pomiędzy sprzedającym i nabywcą aktywów. W rezultacie sprzedający może pozostać z portfelem wątpliwych jakościowo kredytów, co zagraża destabilizacją dochodów banku. Ryzyko transakcji może być także wynikiem zmiany stanu ryzyka już po dokonaniu sprzedaży. Transakcja sprzedaży portfela kredytowego może uwzględniać możliwość regresu 
wobec sprzedającego. Ten typ transakcji (put option) pozwala na zwrot długu, a koszt transakcji i jej odwołania ponosi sprzedający. Możliwa jest także sprzedaż samych roszczeń do oczekiwanego strumienia środków pieniężnych ze spłat kapitału oraz odsetek. W takim przypadku nabywca praw, nie ma prawa regresu do kredytobiorcy (Rose, 1997, s. 88-91).

Akredytywy gwarancyjne (financial guarantees) są instrumentem wzmocnienia standingu, zabezpieczającym kredytobiorcę przed skutkami niewywiązywania się z postanowień umowy kredytowej. Akredytywa gwarancyjna standby jest warunkowym zobowiązaniem (contigent obligation) wystawcy akredytywy, który w zamian za opłatę, godzi się gwarantować spłatę kredytu. Natomiast wystawca akredytywy jest beneficjentem następujących korzyści finansowych:

1) akredytywy przynoszą wystawcy dochód w postaci opłat, liczony jako uzgodniony procent od kwoty zadłużenia kredytowego;

2) niskie prawdopodobieństwo, że wystawca gwarancji będzie wezwany do zapłaty zobowiązań kredytobiorcy z uwagi na preferencyjne warunki kredytu zabezpieczonego gwarancją standby (Rose, 1997, s. 92-99).

Akredytywy nie są depozytem bezpiecznym. Beneficjent akredytywy funkcjonuje w stanie ryzyka, spowodowanego prawdopodobnym niewywiązywaniem się z zobowiązań przez kredytobiorcę. W wyniku czego oczekiwany strumień należności nie wpływa do beneficjenta akredytywy, a stan ryzyka potęguje możliwe bankructwo wystawcy akredytyw.

Hedging to instrument finansowy ograniczający skutki ryzyka walutowego, ale nie tylko, to również instrument używany w innych transakcjach walutowych, także w obrocie towarowym. Instrument skierowany do podmiotów gospodarczych, ale możliwe jest także jego wykorzystanie do zabezpieczenia kredytobiorcy przed skutkami wzrostu kursu waluty indeksacji. Kredytobiorca zabezpiecza dowolną liczbę „, $n$ ” rat w kwocie „ $R$ ” każda. „ $R$ ” jest określona w walucie indeksacji, oznacza to, że w wyniku zawarcia kontraktu CDF (Contract for Difference) zostaje zdeponowany i zablokowany w banku depozyt w kwocie $n R$ w walucie indeksacji według kursu „k”. Odsetki wygenerowane przez depozyt walutowy są niższe aniżeli odsetki, które mógłby wygenerować depozyt w walucie polskiej równowarty depozytowi w walucie indeksacji. Różnicę odsetek wyrównuje mechanizm punktów swapowych. Jeśli kurs waluty indeksacji wzrasta o 5\%, to jednostka waluty indeksacji kosztuje 1,05 $\mathrm{k}$. Nowa cena jednostkowa waluty indeksacji w walucie krajowej wzrasta o $0,05 k$. Wyższy koszt rekompensuje zysk z instrumentu finansowego, waluta będzie bowiem „sprzedawana” po cenie wyższej, dokładnie o $0,05 \mathrm{k}$. 
Zabezpieczenia przed skutkami ryzyka wzrostu kursu walutowego uzupełniają produkty zakładów ubezpieczeniowych. Oferta obejmuje: ubezpieczenie kredytu hipotecznego, ubezpieczenie od utraty wartości nieruchomości stanowiącej zabezpieczenie kredytu, ubezpieczenie nieruchomości od wad prawnych (Monkiewicz, 2005, s. 294-295). Obok ubezpieczeń obligatoryjnych dostępne są ubezpieczenia dobrowolne: ubezpieczenie nieruchomości stanowiące zabezpieczenie kredytu, ubezpieczenie kredytu z niskim wkładem własnym, ubezpieczenie na wypadek czasowej bądź całkowitej niezdolności do pracy, ubezpieczenie na wypadek śmierci kredytobiorcy w okresie spłaty kredytu.

Ogólne warunki ubezpieczenia (OWU) określają warunki wystąpienia szkody i dopiero uznanie przez Zakład Ubezpieczeń takiego zdarzenia, uruchamia proces likwidacji szkody, wypłaty kwoty zobowiązań wobec beneficjenta. Ubezpieczenie kredytu bankowego chroni jednocześnie Bank, który jest beneficjentem wypłaty odszkodowania i chroni kredytobiorcę przed skutkami utraty płynności finansowej bądź niewypłacalności.

\section{Zakończenie}

Scenariusz utraty płynności finansowej umożliwił zdefiniowanie ryzyka kredytu hipotecznego indeksowanego walutą obcą. Źródłem ryzyka jest wzrost kursu waluty indeksacji oraz właściwości produktu hipotecznego, jaką jest równoczesna indeksacja kapitału w walucie polskiej.

Osiągnięto ważny wynik, dowodząc tezę pracy, mianowicie brak dostępu kredytobiorcy do skutecznych instrumentów ochrony przed skutkami ryzyka kursowego, do jakich miały dostęp banki. Wynika z tego brak symetrii podziału skutków ryzyka wzrostu kursu waluty indeksacji pomiędzy bank i kredytobiorcę. Dokonując oceny właściwości instrumentów zarządzania w warunkach wzrostu kursu walutowego, dostrzeżono asymetrię zasobów skutecznych instrumentów ochrony przed skutkami ryzyka dostępnych kredytobiorcy i bankowi, co stanowiło fundament dowodu tezy pracy.

Identyfikacja instrumentów zarządzania w warunkach ryzyka wzrostu kursu walutowego podkreśla rozdzielność zbiorów instrumentów banku i kredytobiorcy. Skuteczność instrumentów preferuje bank. Kontrakty FX SWAP oraz CIRS, główne instrumenty zarządzania w warunkach ryzyka walutowego, skutecznie i efektywnie po najniższych kosztach zostały włączone w system zabezpieczeń banku przed skutkami ryzyka walutowego. Istotnym elementem ochrony banku przed skutkami ryzyka wzrostu kursu walutowego jest „refundacja" różnicy pomiędzy oprocentowaniem walut kontraktu FX SWAP przy „uruchomieniu” kontraktu CIRS, który łączy się z drugim, końcowym eta- 
pem przepływu walut pomiędzy kontrahentami kontraktu. Bank jeszcze przed rozpoczęciem sprzedaży kredytów hipotecznych indeksowanych walutą obcą miał możliwość zabezpieczyć w pełni skutki ryzyka wzrostu kursu walutowego (mBank, 2013).

W krańcowo innej sytuacji jest kredytobiorca, jakim bowiem potencjałem ochrony własnej pozycji wobec wzrostu kursu waluty indeksacji on dysponuje? Hedging jest instrumentem dostępnym dla kredytobiorcy, jest skuteczny, ale wymaga rezerwy zasobu finansowego na ustanowienie depozytu będącego odpowiednikiem depozytu waluty indeksacji, jest instrumentem o krótkim okresie ochrony, trudno tu o zabezpieczenie w całym okresie spłaty zobowiązań kredytowych (Rose, 1997, s. 146-151). Takiego problemu nie ma bank, zabezpieczeniem transakcji są depozyty - środki klientów.

Typowym, najczęściej stosowanym zabezpieczeniem przed skutkami wzrostu kursu waluty indeksacji jest aneks do umowy kredytowej, umożliwiający spłatę kredytu w walucie indeksacji. Innym instrumentem ochrony przed ryzykiem walutowym jest zakup waluty indeksacji w kantorze internetowym. Zasada zakupu waluty na podstawie zlecenia oczekującego, umożliwia pozyskanie waluty indeksacji według kursu o określonym przez kredytobiorcę poziomie. Wadą rozwiązania jest możliwość zakupu waluty indeksacji tylko za środki, które są dostępne dla kredytobiorcy. Ten instrument nie wykorzystuje tzw. lewarowania finansowego, nie ma właściwości transakcji bilansowej, jaką ma hedging.

Drugą grupę instrumentów zabezpieczania przed skutkami ryzyka oferują zakłady ubezpieczeniowe. Ubezpieczenia finansowe są trudno dostępne dla przeciętnego kredytobiorcy, są drogie i mają istotną cechę - są instrumentami warunkowymi, funkcjonują, gdy ubezpieczyciel uzna, że skutki ryzyka są wynikiem okoliczności zdefiniowanych w Ogólnych Warunkach Ubezpieczenia (OWU) instrumentu ubezpieczeniowego.

Podejmując ryzyko kredytu hipotecznego indeksowanego walutą obcą, kredytobiorca powinien mieć świadomość, że większość skutecznych i efektywnych instrumentów, które są dostępne dla banku jest dla niego niedostępnych. Te, których może użyć są ryzykowne bądź wymagają zasobu wolnych środków finansowych, którymi najczęściej nie dysponuje. Pewnym zabezpieczeniem byłoby dostosowywanie dochodów do wzrostu kursu waluty indeksacji, co jest nierealne i wzmacnia tezę pracy. 


\section{Bibliografia}

Czerwińska, T. i Jajuga, K. (2016). Ryzyko Instytucji finansowych. Wspótczesne trendy i wyzwania. Warszawa: C.H. Beck.

Dellmann, K. (1992). Eine Systematisierung der Grundlagen des Controlling. W: K. Spremann, E. Zur (Hrsg), Controlling: Grundlagen - Informationssysteme - Anwendungen (s. 113-140). Wiesbaden: Gabler.

Grzywacz, J. (2002). Podstawy bankowości. System bankowy. Kredyty i rozliczenia. Ryzyko i ocean banku. Marketing. Warszawa: Difin, s. 177.

Holliwell, J. (2001). Ryzyko finansowe. Metody identyfikacji i zarzadzania ryzykiem. Warszawa: K.E. Liber.

Jajuga, K. i Jajuga, T. (2006). Inwestycje Instrumenty Finansowe Aktywa Niefinansowe Ryzyko Finansowe Inżynieria Finansowa. Warszawa: Wydawnictwo Naukowe PWN.

Jaworski, W.L. i Zawadzka, Z. (red.). (2007). Bankowość: podręcznik akademicki. Warszawa: Poltext.

KNB. (2006). Rekomendacja R, 2006-03-15. Warszawa: Komisja Nadzoru Bankowego.

KNB. (2013). Rekomendacja S, 2013-03-08. Warszawa: Komisja Nadzoru Bankowego.

KNF. (2015). Raport o sytuacji banków w 2014. Warszawa: KNF.

mBank. (2013). Regulamin, Walutowe transakcje zamiany stóp procentowych (CIRS). Warszawa: mBank.

McDougall, A. (2001). Swapy. Kraków: Dom wydawniczy ABC.

Milewski, R. i Kwiatkowski, E. (2005). Podstawy ekonomii. Warszawa: Wydawnictwo Naukowe PWN.

MILLENNIUM Bank SA. (2005). Sprawozdanie finansowe MILLENNIUM Bank SA za 2005 rok. Warszawa: MILLENNIUM Bank SA.

Monkiewicz, J. (red.). (2005). Podstawy ubezpieczeń, t. II - produkty. Warszawa: Poltext.

Podgórska, M. i Klimkowska, J. (2013). Matematyka finansowa. Warszawa: PWN.

Rose, P.S. (1997). Zarządzanie bankiem komercyjnym, T. II. Warszawa: Związek Banków Polskich, s. 83-99.

Ustawa z dnia 27 lipca 2002 r. - Prawo dewizowe (Dz.U. $2002 \mathrm{Nr}$ 141, poz. 1178).

ZBP. (2015). Biata księga kredytów frankowych w Polsce. Warszawa: Związek banków Polskich.

Zemke, J. (2015). The risk of hypothecary credit indexed to Swiss franc. Konferencja ENTRENOVA - Kotor Czarnogóra 2015, University of Zagreb, Croatia. 



\title{
Rozdział IV
}

\author{
KAMIL GEMRA*
}

\section{Inwestorzy indywidualni wobec bezprospektowych publicznych emisji obligacji}

Artykuł został poświęcony inwestorom indywidualnym nabywającym obligacje w bezprospektowych publicznych emisjach. Jego celem jest identyfikacja rodzajów ryzyka związanych z inwestowaniem w tego typu emisjach obligacji oraz zaproponowanie zmian, które mogą je ograniczyć. W artykule przedstawiono uwarunkowania prawne dotyczące możliwości prowadzenia emisji obligacji w Polsce, ale kluczową jego część stanowi analiza danych wtórnych dotyczących przeprowadzonych emisji.

Słowa kluczowe: obligacje, publiczna emisja, rynek Catalyst.

\section{Individual investors towards public issue of bonds without prospectus}

Article is dedicated to individual investors purchasing bonds without prospectus in public issues. Aim of article is to identify risks associated with investing in this type of bonds and shows which changes could be implemented to limitate those risks. The article presents legal environment connected with bond issue in Poland, but the key part is an analysis of secondary data concerning the conducted emissions. Mentioned analysis allowed to identyfy the main risks and propose solutions that would reduce risks of investing in bonds.

Keywords: bonds, public issue, the Catalyst market.

JEL: G10

dr Kamil Gemra - Szkoła Główna Handlowa w Warszawie, Kolegium Nauk o Przedsiębiorstwie, al. Niepodległości 162, 02-554 Warszawa; e-mail:kamil.gemra@gmail.com 


\section{Wprowadzenie}

Powstanie rynku Catalyst w 2009 roku przyczyniło się znacząco do popularyzacji obligacji jako instrumentu zarówno finansowania przedsiębiorstw, jak i do lokowania oszczędności przez inwestorów indywidualnych. Wystarczy wspomnieć, że według danych publikowanych w raportach NBP w latach 2002-2009 z emisji obligacji przedsiębiorstwa pozyskały 23,8 mld zł, natomiast w latach 2010-2014, kiedy działał u nas już rynek obligacji Catalyst, firmy z emisji obligacji pozyskały 70,7 mld zl. Wzrost wykorzystania obligacji jako źródła kapitału jest zatem bezsprzeczny. Jednak tak duży wzrost nie byłby możliwy bez drugiej strony transakcji, jaką są nabywcy obligacji, w tym inwestorzy indywidualni. Mają oni możliwość nabywania obligacji w ofertach prywatnych i publicznych. W 2013 roku doszło do ważnej z ich punktu widzenia nowelizacji ustawy o ofercie publicznej, ponieważ wówczas wprowadzono nową możliwość przeprowadzania emisji. Chodzi o publiczną emisję o wartości do 2,5 mln euro przeprowadzaną na podstawie memorandum informacyjnego, jednocześnie bez konieczności sporządzania prospektu emisyjnego i zatwierdzania go przez Komisję Nadzoru Finansowego. Intencją zmian było uproszczenie prowadzenia emisji dla małych spółek.

Celem niniejszego artykułu jest identyfikacja rodzajów ryzyka związanych $\mathrm{z}$ inwestowaniem w publicznych bezprospektowych emisjach obligacji przez inwestorów indywidualnych oraz zaproponowanie zmian, które mogą ograniczyć te rodzaje ryzyka. Realizacja celu artykułu zostanie osiągnięta poprzez analizę danych wtórnych dotyczących przeprowadzonych emisji obligacji od momentu wprowadzenia nowych przepisów prawnych w kwietniu 2013 roku do końca III kwartału 2016 r.

\section{Prawne aspekty emisji obligacji}

Obligacja to swego rodzaju pożyczka, do której spłaty w warunkach emisji zobowiązuje się jej emitent (Sławiński, 2006, s. 30). Świadczenie może mieć formę zarówno pieniężną, jak i niepieniężną, gdzie przykładem mogą być obligacje zamienne na akcje (Pastusiak, 2010, s. 90). Możliwość modelowania struktury emisji bezpośrednio wpływa na koszt pozyskania kapitału, jednocześnie sprzyjając pokryciu faktycznego zapotrzebowania na kapitał. Efekt ten osiaggany jest przykładowo, gdy przedsiębiorstwo podzieliło emisję na transze w ramach programu emisji (Podedworna-Tarnowska, 2009, s. 499).

W Polsce, przed powstaniem rynku Catalyst, trudno było mówić o w pełni działającym zorganizowanym rynku obrotu (Kordela, 2012, s. 170). Oczywiście pojawiały się transakcje, głównie w formule emisji prywatnych kierowanych do 
niewielkiej liczby inwestorów. Natomiast brak zorganizowanego rynku obrotu papierami dłużnymi był swego rodzaju hamulcem w rozwoju rynku obligacyjnego. Praktycznie nie istniał wówczas rynek wtórny, ponieważ inwestorzy trzymali obligacje do wykupu lub zamiany na akcje (Antkiewicz, 2012, s. 148). Kluczowym podmiotem rynku obligacji była Centralna Tabela Ofert, która później przekształciła się w MTS CeTO. Dopiero powstanie zorganizowanego rynku obrotu obligacjami w Polsce, jakim jest rynek Catalyst, dało impuls do zwiększenia wykorzystywania obligacji jako źródła finansowania działalności przedsiębiorstw. Rynek Catalyst ruszył 30 września 2009 roku. Jest on ciągle niewielki i niedoświadczony, ale rozwija się dynamicznie (Czerwiński, 2011, s. 63).

Ważną częścią rynku obligacji korporacyjnych jest rynek pierwotny. Jeżeli chodzi o tryb emisji obligacji to ustawodawca przewidział następujące możliwości:

- emisję niepubliczną, określaną jako emisję prywatną lub zamkniętą:

- emisję publiczną przeprowadzoną w oparciu o zapisy w ustawie o ofercie publicznej lub z pominięciem zapisów tejże ustawy (ustawa o ofercie publicznej).

Ofertą niepubliczną (prywatną) jest proponowanie nabycia papierów wartościowych skierowane do najwyżej 149 imiennie wskazanych osób. W tym przypadku nie jest wymagane sporządzanie ani prospektu emisyjnego, ani memorandum informacyjnego. Emitent sporządza propozycję nabycia zgodnie z ustawą o obligacjach i udostępnia ją wybranym osobom. Przyjęcie propozycji następuje poprzez złożenie odpowiedniego oświadczenia woli oraz dokonanie wpłaty na wskazany rachunek subskrypcyjny.

Ofertą publiczną jest udostępnianie, co najmniej 150 osobom lub nieoznaczonemu adresatowi, w dowolnej formie i w dowolny sposób, informacji o papierach wartościowych i warunkach ich nabycia stanowiących wystarczająca podstawę do podjęcia decyzji o nabyciu tych papierów wartościowych. Oferta publiczna wymaga sporządzenia publicznego dokumentu informacyjnego - prospektu emisyjnego lub memorandum informacyjnego, uzyskania zatwierdzenia go przez Komisję Nadzoru Finansowego oraz udostępnienia go do publicznej wiadomości.

Historycznie pierwsze regulacje prawne dotyczące obligacji w Polsce sięgają dwudziestolecia międzywojennego (Gruszczyńska-Brożbar, 2002, s. 97). Natomiast z perspektywy rynku pierwotnego kluczowym aktem prawnym regulującym emisje jest ustawa z dnia 29 lipca 2005 r. o ofercie publicznej i warunkach wprowadzania instrumentów finansowych do zorganizowanego systemu obrotu oraz o spółkach publicznych. W 2013 roku doszło do ważnej nowelizacji tej 
ustawy poprzez wprowadzenie ustawy z dnia 8 marca 2013 roku o zmianie ustawy o ofercie publicznej i warunkach wprowadzania instrumentów finansowych do zorganizowanego systemu obrotu oraz o spółkach publicznych oraz niektórych innych ustaw. Obowiązuje ona od 23 kwietnia 2013 roku. Najważniejsze zmiany, jakie zaszły w ustawie dotyczące emisji obligacji są następujące:

- zmiana definicji publicznej oferty,

- zmiana zasad prowadzenia akcji promocyjnej przy emisji papierów wartościowych,

- możliwość publicznej emisji papierów wartościowych bez zatwierdzania dokumentu ofertowego przez KNF,

- wprowadzenie instytucji oferty kaskadowej,

- sankcje administracyjne i karne.

Jeżeli chodzi o zmianę definicji oferty publicznej, kluczowe jest to, iż od nowelizacji ustawy oferta publiczna jest ofertą kierowaną do co najmniej 150 osób lub nieoznaczonego adresata. Wcześniejsza definicja mówiła o co najmniej 100 osobach lub nieoznaczonym adresacie. Zatem po nowelizacji oferta prywatna jest kierowana do maksymalnie 149 osób, a nie jak wcześniej do 99 osób.

W ustawie doszło również do zmian zasad prowadzenia akcji promocyjnej. Prowadzenie takiej akcji jest praktycznie możliwe jedynie przy publicznych emisjach po zatwierdzonym prospekcie. W przypadku emisji prywatnych nie można prowadzić akcji promocyjnej. W emisji publicznej bez prospektu można prowadzić akcję promocyjną, ale wcześniej materiały zatwierdza KNF. Jednocześnie doszło do zaostrzenia sankcji dotyczącej akcji promocyjnej. Złamanie zapisów ustawy grozi karą do $10 \mathrm{mln}$ zł oraz karą więzienia do 2 lat.

Jednak najważniejszą zmianą w ustawie było wprowadzenie możliwości publicznej emisji papierów wartościowych o wartości do 2,5 mln euro bez prospektu emisyjnego.

Główne zalety tego rozwiązania to:

- brak prospektu emisyjnego, a zatem skrócenie procedury emisji i ograniczenie kosztów;

- KNF nie zatwierdza memorandum informacyjnego, choć istnieje obowiązek jego napisania i opublikowania;

- możliwość prowadzenia akcji promocyjnej do nieoznaczonego adresata.

Natomiast wśród wad nowych regulacji można wymienić:

- mała wartość dopuszczalnej oferty - maksymalnie 2,5 mln zł w ciągu 12 miesięcy; 
- konieczność pośrednictwa firmy inwestycyjnej, co wiąże się z dodatkowymi kosztami;

- wymagane zatwierdzenie akcji promocyjnej przez KNF.

Wprowadzone zmiany, które dotyczyły publicznej emisji bez prospektu okazały się szansą dla mniejszych firm, które ofertę zakupu obligacji chciały skierować głównie do inwestorów indywidualnych. Emitenci mogą bowiem dzięki szerokiej akcji promocyjnej docierać do praktycznie każdego inwestora, ponieważ bariera wejścia jest stosunkowo niska (Gemra, 2016, s. 203-206).

\section{Analiza przeprowadzonych emisji w latach 2013-2016}

Intencją zmian w ustawie o ofercie publicznej w 2013 roku było uporządkowanie rynku i wyznaczenie jasnych granic pomiędzy ofertą publiczną a prywatną. Wcześniej bowiem wielokrotnie dochodziło do zatarcia się różnic pomiędzy tymi dwiema formami pozyskiwania kapitału. Otóż oferta publiczna wymaga sporządzenia prospektu emisyjnego i zatrudnienia domu maklerskiego. Wiąże się to przede wszystkim ze znacznie wyższymi kosztami, a dodatkowo cały proces może trwać nawet kilka miesięcy. W związku z tym spółki chętniej pozyskiwały kapitał poprzez emisje prywatne, które są znacznie łatwiejszą procedurą bez konieczności chociażby przechodzenia procedury przed KNF-em. Z założenia podstawową różnicą pomiędzy ofertą publiczną a prywatną jest jej grupa odbiorców. O ofercie publicznej można informować szerokie grono odbiorców, żaden inwestor nie powinien mieć problemów z pozyskaniem o niej informacji. Natomiast przed nowelizacją ustawy problemem były nieprecyzyjne przepisy, które nie określały jasno co oznacza informowanie o ofercie. W związku z tym wielu emitentów podchodziło do tego zagadnienia dosyć liberalnie i zdobycie informacji o prywatnych emisjach nie stanowiło żadnego problemu. W odpowiedzi na tę sytuację zaostrzono przepisy, jasno definiując co oznacza informowanie o prywatnej ofercie i do kogo może być kierowana. Jednocześnie, aby nie zamykać drogi małym emitentom do pozyskiwania kapitału od inwestorów indywidualnych, umożliwiono prowadzenie nowego rodzaju ofert - publiczne oferty o wartości do 2,5 mln euro, o których specyfice wspomniano w poprzedniej części artykułu.

W tabeli 1 zawarto wszystkich emitentów, którzy zdecydowali się przeprowadzić tego typu emisję od obowiązywania znowelizowanych przepisów do końca trzeciego kwartału 2016 roku. 
Ta b e la 1. Branże emitentów prowadzących publiczne bezprospektowe emisje obligacji w okresie od 23.04.2013 r. do 30.09.2016 r.

\begin{tabular}{|l|l|}
\hline \multicolumn{1}{|c|}{ Emitent } & \multicolumn{1}{c|}{ Branża } \\
\hline PTI & finansowa \\
\hline Polfa & farmaceutyczna \\
\hline Aforti Holding & finansowa \\
\hline Zortrax & druk 3D \\
\hline Organika & chemiczna \\
\hline LZMO & budowlana \\
\hline Hussar Gruppa & transportowa \\
\hline Biomax & farmaceutyczna \\
\hline Mikrokasa & pożyczkowa \\
\hline Robinson & handlowa \\
\hline Mikrokasa & pożyczkowa \\
\hline Fundusz Hipoteczny Dom SA S.K.A. & finansowa \\
\hline 4 fun Media & telewizyjna \\
\hline Marka & pożyczkowa \\
\hline Admiral Boats & produkcyjna \\
\hline Mikrokasa & pożyczkowa \\
\hline SMS Kredyt Holding & pożyczkowa \\
\hline Arrinera & samochodowa \\
\hline Marka & pożyczkowa \\
\hline Kerdos Group & handlowa \\
\hline Mikrokasa & pożyczkowa \\
\hline Premium Pozyczki & pożyczkowa \\
\hline OT Logistics & logistyka \\
\hline Fabryka Konstrukcji Drewnianych & produkcyjna \\
\hline CreamFinance Poland & pożyczkowa \\
\hline Prodigo Recycling & recycling \\
\hline Legimi & handlowa \\
\hline AOW Faktoring & finansowa \\
\hline BVT & windykacyjna \\
\hline Auxilia & finansowa \\
\hline Vantage Development & deweloperska \\
\hline Ronson Europe & deweloperska \\
\hline & \\
\hline fowane & \\
\hline
\end{tabular}

Źródło: opracowanie własne.

Dominujące branże wśród emitentów obligacji w analizowanych emisjach to przede wszystkim firmy pożyczkowe oraz finansowe. Zapewne jest to związane ze specyfiką ich działania. Mają one bowiem utrudniony dostęp do finansowania bankowego. Firmy pożyczkowe nie posiadają tzw. twardych zabezpieczeń w postaci chociażby nieruchomości, a ponadto są konkurencją dla banków. Problemy z zabezpieczeniem wymaganym w bankach oraz modelem bizneso- 
wym sprawiają też, że firmy z szeroko rozumianej branży finansowej zmagają się z utrudnionym dostępem do kredytów. Dlatego tego typu firmy decydują się na publiczne oferty obligacji, aby w ten sposób dotrzeć do szerokiego grona inwestorów indywidualnych i pozyskać kapitał.

Analiza prowadzonych ofert wymaga spojrzenia na podstawowe parametry emitowanych obligacji, które zawarto w tabeli 2.

Ta b e l a 2. Oprocentowanie i czas trwania obligacji emitentów prowadzących publiczne bezprospektowe emisje obligacji w okresie od 23.04.2013 r. do 30.09.2016 r.

\begin{tabular}{|c|c|c|}
\hline Spółka & Oprocentowanie & Czas trwania obligacji (w latach) \\
\hline PTI & WIBOR $6 \mathrm{M}+5,00$ & 2,0 \\
\hline Polfa & WIBOR $3 \mathrm{M}+7,00$ & 3,0 \\
\hline Aforti Holding & 9,00 & 1,0 \\
\hline Zortrax & 9,00 & 3,0 \\
\hline Organika & 8,25 & 3,0 \\
\hline LZMO & 8,75 & 2,5 \\
\hline Hussar Gruppa & 8,50 & 3,0 \\
\hline Biomax & 9,50 & 2,5 \\
\hline Mikrokasa & 9,50 & 2,0 \\
\hline Robinson & WIBOR 3M + 7,00 & 3,0 \\
\hline Mikrokasa & 9,20 & 2,0 \\
\hline Fundusz Hipoteczny Dom SA S.K.A. & 8,50 & 3,0 \\
\hline Marka & 9,50 & 2,0 \\
\hline Admiral Boats & 8,50 & 2,5 \\
\hline Mikrokasa & 9,00 & 2,0 \\
\hline SMS Kredyt Holding & 9,00 & 3,0 \\
\hline Arrinera & 9,50 & 2,0 \\
\hline Marka & 9,00 & 2,0 \\
\hline Kerdos Group & 8,00 & 3,0 \\
\hline Mikrokasa & 8,70 & 2,0 \\
\hline Premium Pozyczki & 9,50 & 2,0 \\
\hline OT Logistics & 5,40 & 3,0 \\
\hline Fabryka Konstrukcji Drewnianych & 9,00 & 2,0 \\
\hline CreamFinance Poland & 9,00 & 1,0 \\
\hline Prodigo Recycling & 8,75 & 2,0 \\
\hline Legimi & 9,50 & 2,0 \\
\hline AOW Faktoring & WIBOR 3M + 4,70 & 3,0 \\
\hline BVT & 8,00 & 2,5 \\
\hline Auxilia & 9,00 & 2,5 \\
\hline Vantage Development & WIBOR $3 \mathrm{M}+4,32$ & 3,5 \\
\hline Ronson Europe & 5,25 & 4,0 \\
\hline
\end{tabular}

Źródło: opracowanie własne. 
Ta b e l a 3. Maksymalna wartość pozyskiwanego kapitału w emisji, ostateczna wartość, jaką udało się pozyskać oraz próg dojścia emisji do skutku emitentów prowadzących publiczne bezprospektowe emisje obligacji w okresie od 23.04.2013 r. do 30.09.2016 r. (dane w mln zl)

\begin{tabular}{|c|c|c|c|}
\hline Spółka & $\begin{array}{c}\text { Maksymalna wartość } \\
\text { pozyskiwanego kapitału }\end{array}$ & $\begin{array}{c}\text { Ostateczna wartość } \\
\text { pozyskanego kapitału }\end{array}$ & $\begin{array}{c}\text { Próg dojścia } \\
\text { emisji do skutku }\end{array}$ \\
\hline PTI & 9,00 & 6,700 & 4,00 \\
\hline Polfa & 10,00 & 6,000 & 5,00 \\
\hline Aforti Holding & 5,00 & 2,500 & 2,00 \\
\hline Zortrax & 10,00 & 6,000 & 6,00 \\
\hline Organika & 10,00 & 6,200 & 6,00 \\
\hline LZMO & 7,00 & 6,100 & 3,00 \\
\hline Hussar Gruppa & 10,00 & 1,700 & 1,50 \\
\hline Biomax & 4,00 & 2,100 & 2,00 \\
\hline Mikrokasa & 2,00 & 2,000 & 0,50 \\
\hline Robinson & 4,00 & 1,000 & 1,00 \\
\hline Mikrokasa & 2,00 & 2,000 & 1,00 \\
\hline $\begin{array}{l}\text { Fundusz Hipoteczny } \\
\text { Dom SA S.K.A. }\end{array}$ & 10,00 & 3,570 & 3,00 \\
\hline 4 fun Media & 6,00 & $\begin{array}{l}\text { emisja nie doszła } \\
\text { do skutku }\end{array}$ & 3,00 \\
\hline Marka & 2,00 & 2,000 & 1,00 \\
\hline Admiral Boats & 6,00 & 6,000 & 3,00 \\
\hline Mikrokasa & 3,00 & 1,700 & 1,00 \\
\hline SMS Kredyt Holding & 9,00 & 3,011 & 3,00 \\
\hline Arrinera & 5,00 & 2,050 & 2,00 \\
\hline Marka & 2,00 & 1,089 & 1,00 \\
\hline Kerdos Group & 6,00 & 4,052 & 4,00 \\
\hline Mikrokasa & 3,00 & 1,070 & 1,00 \\
\hline Premium Pozyczki & 3,00 & 0,400 & 0,40 \\
\hline OT Logistics & 10,00 & 10,000 & brak progu \\
\hline $\begin{array}{l}\text { Fabryka Konstrukcji } \\
\text { Drewnianych }\end{array}$ & 10,25 & $\begin{array}{c}\text { emisja nie doszła } \\
\text { do skutku }\end{array}$ & 7,50 \\
\hline CreamFinance Poland & 2,00 & 1,700 & 1,00 \\
\hline Prodigo Recycling & 3,00 & 0,570 & brak progu \\
\hline Legimi & 1,50 & 1,230 & 0,75 \\
\hline AOW Faktoring & 5,00 & 5,000 & brak progu \\
\hline BVT & 5,00 & 3,080 & 2,00 \\
\hline Auxilia & 3,00 & 2,770 & 1,00 \\
\hline Vantage Development & 10,50 & 10,500 & brak progu \\
\hline Ronson Europe & 10,00 & 10,000 & brak progu \\
\hline
\end{tabular}

Źródło: opracowanie własne. 
Wśród analizowanych emitentów dominują obligacje dwu- i trzyletnie. Jedynie dwóm deweloperom Vantage i Ronson notowanych na głównym rynku GPW udało się uplasować obligacje o czasie trwania dłuższym niż 3 lata. Jednocześnie te dwie firmy oraz OT Logistics i AOW Faktoring mogą pochwalić się stosunkowo niskim kosztem pozyskania kapitału, jaki przejawia się w oferowanym oprocentowaniu. Natomiast u pozostałych emitentów koszt kapitału waha się od 8 do ponad $9 \%$ w skali roku. Co ciekawe mimo spadku rynkowych stóp procentowych od 2013 roku oferowane oprocentowanie pozostaje na wysokim poziomie. Może to świadczyć o tym, że emitenci charakteryzują się podwyższonym ryzykiem, płacąc za swój dług stosunkowo dużo. Według statystyk z raportu Grant Thornton po 6 latach działania całego rynku Catalyst dominujące oprocentowanie wszystkich obligacji znajduje się w przedziale 6-7\% w skali roku. Ponadto, analizując konstrukcję oferowanego oprocentowania, widać, że emitenci preferują stałe oprocentowanie. Może to mieć związek z tym, że obligacje przeznaczone są dla inwestorów indywidualnych, którzy chcą od samego początku znać dokładnie rentowność swojej inwestycji, a oprocentowanie stałe im to umożliwia.

Oprócz analizy oprocentowania warto spojrzeć na wielkości emisji obligacji. W tabeli 3 przedstawiono wartości maksymalne kapitału, jakie chciały pozyskać firmy, do tego wartości minimalne emisji oraz to ile udawało się ostatecznie pozyskać.

Jedynie niewielkiej liczbie emitentów udaje się pozyskać kapitał o wartości maksymalnej, o jaką występują u inwestorów. Ponadto wartości minimalne emisji w sposób znaczący różnią się od wartości maksymalnych, co może wskazywać, że projekty, na które potrzebne są kapitały z emisji obligacji nie do końca są przemyślanie i zaplanowane. Problemem bowiem jest to, że firmy w wielu wypadkach pozyskiwała jedynie nieco więcej niż minimalna wartość emisji, a co w przypadku spółek Premium Pożyczki czy Hussar Gruppa doszło do obniżenia wartości progu dojścia emisji do skutku. Dodatkowo często spotykanym zabiegiem jest przesuwanie terminu zapisów, a konkretniej ich wydłużanie, tak, aby za wszelką cenę pozyskać niezbędny kapitał i zakończyć emisję sukcesem.

Kolejnym etapem analizy parametrów oferowanych obligacji jest ich zabezpieczenie. W prowadzonych emisjach większość oferowanych obligacji jest zabezpieczona. Dane te przedstawia tabela 4. 
Ta b e l a 4. Zabezpieczenie emisji obligacji emitentów prowadzących publiczne bezprospektowe emisje obligacji w okresie od 23.04.2013 r. do 30.09.2016 r.

\begin{tabular}{|c|c|}
\hline Spółka & Zabezpieczenie \\
\hline PTI & niezabezpieczone \\
\hline Polfa & zastaw na znaku towarowym \\
\hline Aforti Holding & niezabezpieczone \\
\hline Zortrax & niezabezpieczone \\
\hline Organika & nieruchomości \\
\hline LZMO & nieruchomości \\
\hline Hussar Gruppa & niezabezpieczone \\
\hline Biomax & zastaw na akcjach emitenta \\
\hline Mikrokasa & zabezpieczenie na wierzytelnościach \\
\hline Robinson & zastaw na znakach towarowych \\
\hline Mikrokasa & zabezpieczenie na wierzytelnościach \\
\hline Fundusz Hipoteczny Dom SA S.K.A. & poręczenie właściciela \\
\hline Marka & zabezpieczenie na wierzytelnościach \\
\hline Admiral Boats & hipoteka \\
\hline Mikrokasa & niezabezpieczone \\
\hline SMS Kredyt Holding & niezabezpieczone \\
\hline Arrinera & zastaw na akcjach \\
\hline Marka & zabezpieczenie na wierzytelnościach \\
\hline Kerdos Group & zastaw na udziałach w Dayli \\
\hline Mikrokasa & zabezpieczenie na wierzytelnościach \\
\hline Premium Pozyczki & zabezpieczenie na wierzytelnościach \\
\hline OT Logistics & niezabezpieczone \\
\hline CreamFinance Poland & zabezpieczenie na wierzytelnościach \\
\hline Prodigo Recycling & zastaw i poręczenie \\
\hline Legimi & zastaw na części działalności gospodarczej \\
\hline AOW Faktoring & zabezpieczenie na wierzytelnościach \\
\hline BVT & zabezpieczenie na wierzytelnościach \\
\hline Auxilia & zabezpieczenie na wierzytelnościach \\
\hline Vantage Development & niezabezpieczone \\
\hline Ronson Europe & niezabezpieczone \\
\hline
\end{tabular}

Źródło: opracowanie własne.

Najpopularniejszym zabezpieczeniem wśród analizowanych emitentów jest zastaw na wierzytelnościach, który dotyczy firm pożyczkowych. Ponadto emitenci oferują zabezpieczenie w postaci hipoteki na nieruchomościach. Oprócz tego pojawiają się zastawy na akcjach spółek zależnych, na znakach towaro- 
wych, poręczenia właścicieli czy zastawy na akcjach emitenta. Trzeba sobie jasno powiedzieć, że są to bardzo słabe zabezpieczenia. Otóż firma pożyczkowa nie wykupi obligacji, gdy jej klienci przestaną spłacać swoje pożyczki, zastaw na takim portfelu pożyczek będzie zatem niewiele wart. Twardym zabezpieczeniem wydają się być nieruchomości, ale kwestią sporną zawsze jest ich wycena oraz możliwość upłynnienia. Zabezpieczenia w postaci zastawów na znakach towarowych również mogą być uważane za słabe, ponieważ pozostaje kwestia wyceny i ewentualnej sprzedaży znaku towarowego firmy, która ma kłopoty z obsługą swoich zobowiązań. Najciekawsze może być jednak to, że duże i stabilne firmy, takie jak OT Logistics, Vantage Development czy Ronson Development mogły oferować stosunkowo niskie oprocentowanie przy jednoczesnym braku zabezpieczenia obligacji.

$\mathrm{Na}$ koniec analizy podsumowano statusy wykupów danych obligacji, które zawarto w tabeli 5.

Ta b e l a 5. Terminy zapadalności emisji obligacji oraz ich statusy wykupu emitentów prowadzących publiczne bezprospektowe emisje obligacji w okresie od 23.04.2013 r. do 30.09.2016 r.

\begin{tabular}{|l|c|c|l|}
\hline \multicolumn{1}{|c|}{ Spółka } & $\begin{array}{c}\text { Wartość pozyskanego } \\
\text { kapitału (mIn zt) }\end{array}$ & $\begin{array}{c}\text { Termin wykupu } \\
\text { obligacji }\end{array}$ & Status wykupu, prognoza \\
\hline Aforti Holding & 2,500 & $2016-01-28$ & wykupione \\
\hline PTI & 6,700 & $2016-08-01$ & niewykupione \\
\hline Mikrokasa & 2,000 & $2016-09-02$ & wykupione \\
\hline CreamFinance Poland & 1,700 & $2016-10-18$ & wykupione \\
\hline LZMO & 6,100 & $2016-11-22$ & upadłość \\
\hline Mikrokasa & 2,000 & $2016-11-28$ & spodziewany wykup \\
\hline Biomax & 2,100 & $2017-01-11$ & brak wypłaty odsetek \\
\hline Marka & 2,000 & $2017-02-06$ & - \\
\hline Organika & 6,200 & $2017-03-06$ & trudna sytuacja spółki \\
\hline Zortrax & 6,000 & $2017-03-31$ & - \\
\hline Mikrokasa & 1,700 & $2017-04-03$ & - \\
\hline Arrinera & 2,050 & $2017-04-26$ & - \\
\hline Hussar Gruppa & 1,700 & $2017-05-08$ & - \\
\hline Marka & 1,089 & $2017-05-12$ & - \\
\hline Mikrokasa & 1,070 & $2017-06-29$ & - \\
\hline Premium Pozyczki & 0,400 & $2017-07-10$ & - \\
\hline Admiral Boats & 6,000 & $2017-09-18$ & opóźnienia w wypłacie \\
\hline Robinson & 1,000 & $2017-09-25$ & - \\
\hline
\end{tabular}


cd. t a b. 5

\begin{tabular}{|l|c|c|l|}
\hline \multicolumn{1}{|c|}{ Spółka } & $\begin{array}{c}\text { Wartość pozyskanego } \\
\text { kapitału (mIn zl) }\end{array}$ & $\begin{array}{c}\text { Termin wykupu } \\
\text { obligacji }\end{array}$ & Status wykupu, prognoza \\
\hline Prodigo Recycling & 0,570 & $2017-10-20$ & - \\
\hline Polfa & 6,000 & $2017-12-17$ & upadłość \\
\hline Legimi & 1,230 & $2017-12-18$ & - \\
\hline SMS Kredyt Holding & 3,011 & $2018-04-17$ & - \\
\hline Kerdos Group & 4,052 & $2018-05-29$ & upadłość \\
\hline OT Logistics & 10,000 & $2018-08-18$ & - \\
\hline BVT & 3,080 & $2018-11-30$ & - \\
\hline Auxilia & 2,770 & $2019-01-03$ & - \\
\hline AOW Faktoring & 5,000 & $2019-05-31$ & - \\
\hline Vantage Development & 10,500 & $2020-01-22$ & - \\
\hline Ronson Europe & 10,000 & $2020-08-18$ & - \\
\hline
\end{tabular}

Źródło: opracowanie własne.

Według przedstawionych danych do końca 2016 roku emitenci powinni wykupić obligacje o wartości nominalnej $21 \mathrm{mln}$ zł. Okazuje się jednak, że aż 12,8 mln zł nie zostało wykupionych. Oznacza to, że $60 \%$ planowanych do wykupu obligacji nie zostało spłaconych! Natomiast należy zauważyć, że najwięcej wykupów planowanych jest dopiero na 2017 rok.

\section{Podsumowanie}

Zmiany wprowadzone w ustawie o ofercie publicznej, które obowiązują od kwietnia 2013 roku należy ocenić pozytywnie. Natomiast po kilku latach ich obowiązywania objawiły się rodzaje ryzyka, na które narażeni są inwestorzy indywidualni. Na podstawie analizy danych dotyczących emisji zidentyfikowano następujące rodzaje ww. ryzyka:

1. Spółki, które decydowały się na emisje obligacji kierowaną do inwestorów indywidualnych mają w większości problem z pozyskaniem kapitału dłużnego w inny sposób. Emitenci tacy charakteryzują się podwyższonym ryzykiem, o czym świadczą stosunkowo wysokie oprocentowania, jakie są oferowane inwestorom.

2. Emitenci nie mają skonkretyzowanych planów, często emisje obligacji wyglądają jak emisje kapitału niezbędnego na przetrwanie. Różnica pomiędzy maksymalną a minimalną wartością emitowanych obligacji sięga kilkudziesięciu procent. Dodatkowo zdarza się, że emitenci w czasie trwania emisji zmniejszają wartość minimalnego progu dojścia emisji do skutku, tak 
aby pozyskać jakikolwiek kapitał. Ponadto często spotykamy zjawiskiem jest przedłużanie zapisów, co wynika z braku zainteresowania emisją $\mathrm{w}$ pierwszym okresie jej trwania.

3. Emitenci oferują zabezpieczenia obligacji niskiej jakości. Dominują zastawy na portfelach pożyczek, hipoteki na nieruchomościach czy zastawy na znakach towarowych. Tego typu zabezpieczenie w połączeniu $\mathrm{z}$ niewydolnym prawem upadłościowym $\mathrm{w}$ praktyce uniemożliwiają odzyskanie inwestorom środków w przypadku bankructwa.

4. Zmniejszanie progu dojścia emisji do skutku oraz materializacja innych rodzajów ryzyka sprawia, że zdarzają się przypadki niewprowadzania obligacji na Catalyst, mimo wcześniejszych zapewnień. W takim wypadku inwestorzy nie mają rynku wtórnego i nie mogą wyjść z inwestycji.

Biorąc pod uwage powyższe rodzaje ryzyka, w opinii autora niniejszego artykułu powinno się wprowadzić następujące rozwiązania:

1. Dom maklerski będący oferującym powinien sporządzać raport analityczny poprzez niezależny dział analiz opisujący sytuację emitenta i główne rodzaje ryzyka związane z inwestowaniem w jego obligacje. Obecnie dom maklerski skupia się jedynie na materiałach reklamowych, które mają posłużyć znalezieniu inwestorów i sprzedaniu obligacji.

2. Powinien powstać standard obligacji, który ograniczałby ryzyko inwestorów indywidualnych, a jednocześnie spełnienie zawartych tam wymogów sprawiałoby, że ryzyko niewprowadzenia obligacji na rynek Catalyst byłoby znikome.

3. Każdy emitent powinien mieć obowiązek raportowania o wypłacie odsetek oraz o wykupie obligacji z przynajmniej jednodniowym wyprzedzeniem. Obecnie inwestorzy są zdani sami na siebie i muszą dopytywać się, np. w KDPW, czy emitent przelał środki na wypłatę odsetek.

4. W zakresie zabezpieczenia obligacji większa odpowiedzialność powinna spoczywać na domie maklerskim, który powinien być obowiązkowo administratorem zabezpieczenia obligacji i w przypadku problemów emitenta powinien dążyć do jego spieniężenia i jak najszybszego wypłacenia środków inwestorom.

5. Dom maklerski powinien wspólpracować z emitentem przez cały okres trwania obligacji, tak aby monitorować jego sytuację finansową i usprawnić komunikację pomiędzy emitentem a inwestorami.

6. Jak w każdym przypadku, na rynku kapitałowym niezbędna jest dalsza edukacja inwestorów z zakresu działania rynku Catalyst oraz prowadzenia emisji obligacji. 


\section{Bibliografia}

Antkiewicz, S. (2012). Papiery wartościowe na rynku pieniężnym i kapitałowym. Warszawa: CeDeWu.

Czerwiński, M. (2011). Analiza funkcjonowania publicznego rynku nie skarbowych papierów dłużnych Catalyst. W: K. Jajuga (red.), Finanse - nowe wyzwania teorii i praktyki. Rynek finansowy. Wrocław: Wydawnictwo UE we Wrocławiu.

Gemra, K. (2016). Bezprospektowa emisja obligacji jako źródło finansowania firm z sektora MŚP. W: J. Grzywacz (red.). Źródta finansowania działalności rozwojowej przedsiębiorstw $w$ Polsce. Warszawa: Oficyna Wydawnicza SGH.

Grant Thornton i GPW. (2015). Raport Catalyst: rynek obligacji w 2014 roku. III edycja, czerwiec.

Gruszczyńska-Brożbar, E. (2002). Obligacje instrumentami rynku długoterminowych kapitałów pieniężnych. W: W. Przybylska-Kapuścińska (red.), Rynek papierów wartościowych $w$ Polsce, Wybrane problemy. Poznań: Wydawnictwo Akademia Ekonomiczna w Poznaniu.

Kordela, D. (2012). Rynek Catalyst w strukturze polskiego rynku papierów wartościowych. W: W. Przybylska-Kapuścińska, J. Handschke (red.), Rynki finansowe i ubezpieczenia. Nowe perspektywy instytucji i instrumentów. „Zeszyty Naukowe”, nr 143. Poznań: Wydawnictwo Uniwersytetu Ekonomicznego w Poznaniu.

NBP. (2015). Rozwój systemu finansowego w Polsce w 2014 roku. Warszawa: NBP.

Pastusiak, R. (2010). Przedsiębiorstwo na rynku kapitałowym. Operacje gietdowe rynku publicznego i niepublicznego. Warszawa: CeDeWu.

Podedworna-Tarnowska, D. (2009). Perspektywy rozwoju rynku obligacji korporacyjnych w Polsce. W: D. Zarzecki (red.), Zarzadzanie finansami, aktualne wyzwania teorii i praktyki. Finanse, Rynki finansowe, Ubezpieczenia nr 16. „Zeszyty Naukowe” nr 533. Szczecin: Wydawnictwo Uniwersytetu Szczecińskiego.

Sławiński, A. (2006). Rynki finansowe. Warszawa: PWE.

Ustawa z dnia 29 lipca 2005 r. o ofercie publicznej i warunkach wprowadzania instrumentów finansowych do zorganizowanego systemu obrotu oraz o spółkach publicznych (Dz.U. 2005 Nr 184, poz. 1539). 


\section{Rozdział V}

TOMASZ MIZIOŁEK*

\section{Zmiany stóp zwrotu i płynności akcji spółek po ich ekskluzji z indeksu WIG20}

Celem artykułu jest analiza trwałego efektu indeksowego na polskim rynku akcji w przypadku ekskluzji spółki z indeksu WIG20. Analiza została przeprowadzona na próbie 23 spółek, których akcje zostały usunięte z ww. indeksu w latach 2007-2016. Wyniki badania dotyczącego stóp zwrotu nie pozwoliły na sformułowanie jednoznacznego wniosku, gdyż po roku od wykluczenia siła relatywna (względem indeksu WIG20) 12 spółek była ujemna, 11 - dodatnia, a indeks siły relatywnej całej grupy zmniejszył się jedynie o 4,3\%. W analizowanym okresie zaobserwowano natomiast istotny spadek płynności (aktywności transakcyjnej) w stosunku do analogicznego okresu przed wykluczeniem z indeksu, w przypadku większości firm.

Słowa kluczowe: efekt indeksowy, wykluczenie spółki z indeksu, siła relatywna, płynność, indeks WIG20.

\section{Changes of rates of return and liquidity of companies shares after their exclusion from the WIG20 index}

The aim of the article is to analyse permanent index effect on the Polish equity market in the case of the exclusion of the company from the WIG20 index. The analysis was conducted on a sample of 23 companies, whose shares have been removed from the aforementioned index in 2007-2016. The results of the study concerning rates of return did not allowed to draw a clear conclusion, because after the year after exclusion relative strength (relative to WIG20 index) of 12 companies was negative, 11 was positive, while relative strength index of the whole group decreased only by $4.3 \%$. In the analysed period it was observed a significant drop in liquidity

dr hab. Tomasz Miziołek, prof. UŁ - Katedra Finansów i Inwestycji Międzynarodowych, Uniwersytet Lódzki, ul. P.O.W. 3/5, 90-255 Łódź; e-mail: miziolek@uni.lodz.pl. 
(trading activity), compared to the same period before the exclusion from the index, in the case of most companies.

Keywords: index effect, exclusion of a company from the index, relative strength, liquidity, WIG20 index.

JEL: G11, G14

\section{Wprowadzenie}

Zjawisko efektu indeksowego (index effect) jest przedmiotem badań w literaturze finansowej od 30 lat $^{1}$. Wyniki większości przeprowadzonych dotychczas na różnych rynkach analiz związków pomiędzy włączeniem (inkluzją) lub wykluczeniem (ekskluzją) akcji spółek giełdowych ze składu indeksu a zmianą ich kursów oraz wielkością obrotów wykazały, iż w krótkim okresie (kilku, kilkunastu dni) występuje dostosowanie cenowe polegające na wzroście/spadku cen walorów oraz wzroście/spadku obrotów akcjami firm, które mają pojawić się/zostać usunięte z portfela indeksu. Ten tymczasowy wpływ wyjaśnia się najczęściej, wykorzystując hipotezę presji cenowej (price pressure hypothesis, $\mathrm{PPH})$. Według niej powyższe zmiany są rezultatem dostosowań składu portfeli przez pasywnych inwestorów - głównie fundusze indeksowe i fundusze ETF (a w praktyce także przez część podmiotów aktywnie zarządzających portfelem inwestycyjnym - tych, które preferują benchmarkowe podejście do inwestycji). Dążą oni w ten sposób do zminimalizowania wskaźnika błędu odwzorowania (tracking error), jest to jednak efekt krótkotrwały, gdyż działania ww. podmiotów koncentrują się w okolicach terminu wejścia w życie zmiany składu portfela indeksu. Po skorygowaniu przez nich składu portfela inwestycyjnego presja cenowa $\mathrm{z}$ ich strony znika, a skoro nie zmienia to ceny równowagi w długim okresie, to ceny tych walorów powracają do poprzednich poziomów.

Choć większość badań dotyczących efektu indeksowego skupia się na analizowaniu jego krótkotrwałych (a zatem jedynie przejściowych) skutków, równolegle prowadzone są również badania, które mają za zadanie zweryfikować występowanie długookresowego (trwałego) efektu indeksowego po zrealizowanej zmianie składu indeksu. Teoretyczne wyjaśnienia tego zjawiska opierają się zasadniczo na hipotezie o niedoskonałych substytutach (imperfect substitution hypothesis), zwanej także hipotezą o opadającym popycie (downward-sloping demand hypothesis). W przeciwieństwie do PPH stanowi ona, iż akcje są wobec

1 Pierwsze analizy tego zjawiska przeprowadzili w 1986 r. Harris i Gurel (1986) oraz Shleifer (1986). 
siebie niedoskonałymi substytutami, wobec czego długookresowa krzywa popytu dla akcji jest nieelastyczna i opada w dól. W związku z powyższym krótkoterminowe zmiany popytu powodują zmiany ceny równowagi akcji, co prowadzi do trwałej zmiany jej ceny. W sytuacji włączenia spółki do indeksu pasywni inwestorzy nabywają duże pakiety jej walorów, powodując krótkoterminowy wzrost popytu sugerowany przez PPH. Jednakże, biorąc pod uwagę stan niedoskonałej substytucji, akcje te będą trzymane w dłuższej perspektywie, czego dodatkowym efektem jest ograniczenie liczby akcji dostępnych w obrocie giełdowym. Dlatego też początkowy wzrost popytu na akcje i następujący po tym spadek ich podaży trwale zmienią cenę równowagi w dłużnym okresie; odwrotny przebieg zdarzeń będzie miał miejsce w przypadku ekskluzji spółki z indeksu² .

Wzrost/spadek obrotów akcjami spółki włączanej/wykluczanej z indeksu jest z kolei tłumaczony tym, iż tego rodzaju zdarzenia (zwłaszcza, jeśli dotyczą istotnego na danym rynku indeksu) powodują na ogół wzrost/spadek zainteresowania nią ze strony analityków, co z kolei wpływa na wzrost jej popularności wśród inwestorów zarówno indywidualnych, jak i instytucjonalnych.

Badanie długookresowego efektu indeksowego na polskim rynku akcji w przypadku ekskluzji spółki z indeksu WIG20 - zarówno w kontekście cenowym, jak i płynnościowym - jest głównym celem niniejszego artykułu. Zostanie ono przeprowadzone na podstawie analizy kursów akcji i obrotów akcjami spółek wykluczonych z ww. indeksu w latach 2007-2016. W kolejnych częściach artykułu omówione zostaną wybrane badania dotyczące efektu indeksowego na zagranicznych i na polskim rynku akcji (pkt 1), przedstawione zostaną zastosowane metody badawcze (pkt 2), scharakteryzowana próba badawcza i zaprezentowane źródła wykorzystanych danych (pkt 3) oraz przedstawione najważniejsze wyniki i wnioski wynikające z przeprowadzonego badania (pkt 4).

\section{Przegląd badań}

Badania zmian stóp zwrotu akcji spółek włączanych lub wykluczanych $\mathrm{z}$ indeksu oraz obrotów tymi walorami prowadzone były początkowo przede

2 Poza wymienionymi dwoma najpopularniejszymi hipotezami, w literaturze spotkać można także dwie inne wyjaśniające występowanie efektu indeksowego. Hipoteza informacyjna (information hypothesis) zakłada, że decyzja o inkluzji/ekskluzji spółki do/z indeksu dostarcza inwestorom informacji o jej jakości. Z kolei zgodnie z hipotezą płynności (liquidity hypothesis) włączenie spółki do indeksu powoduje wzrost zainteresowania akcjami spółki ze strony inwestorów, co sprawia, iż pojawia się więcej informacji na jej temat, rosną obroty, dochodzi do obniżenia kosztów transakcyjnych (zawężenia spreadu pomiędzy ofertami kupna i sprzedaży) i ostatecznie do wzrostu ceny jej akcji; odwrotny scenariusz jest realizowany w przypadku usunięcia spółki $\mathrm{z}$ indeksu. 
wszystkim na rynku amerykańskim. Dotyczyły one najpierw indeksu S\&P 500 - autorami tych prac byli m.in.: Jain (1987), Dhillon i Johnsson (1991), Beneish i Whaley (1996) oraz Würgler i Zhuravskaya (2002). Następnie badania te rozszerzono o indeksy opisujące koniunkturę w innych segmentach amerykańskiego rynku akcji - głównie w gronie średnich i małych firm (indeksy S\&P MidCap 400 i S\&P SmallCap 600) (Breazeale i Cuny, 2002). W końcu lat 90. i na początku kolejnej dekady opublikowane zostały pierwsze badania dotyczące indeksów akcyjnych innych rynków rozwiniętych - m.in.: niemieckiego (indeks MDAX) (Steiner i Heinke, 1997), kanadyjskiego (index TSE 300) (Chung i Kryzanowski, 1998), brytyjskiego (indeksy FTSE 100 i FTSE All-Share) (Brealey, 2000), japońskiego (indeks Nikkei 500) (Liu, 2000), nowozelandzkiego (indeksy NZSE 10 i NZSE 40) (Elayan et. al., 2001) i hiszpańskiego (indeks IBEX35) (Gomez Sala i Yzaguirre, 2003). W ostatnich kilkunastu latach analizy o podobnym charakterze zostały przeprowadzone również na wybranych rynkach wschodzących. Dotyczyły one m.in. takich indeksów, jak: tureckich ISE-100 i ISE-30 (Bildik i Gülay, 2008), argentyńskiego Merval (Calafiore i Jackson, 2008), koreańskiego KOSPI 200 (Yun i Kim, 2011), malezyjskiego FTSE Bursa Malaysia KLCI (Kuala Lumpur Composite Index) (Azevedo et. al., 2014), chińskiego SHSZ 300 (He i Wang, 2015) czy brazylijskiego Ibovespa (Nardy, et. al., 2015).

$\mathrm{Na}$ polskim rynku kapitałowym badania trwałego efektu indeksowego po wykluczeniu spółek z indeksu obliczanego przez GPW w Warszawie (we wszystkich przypadkach chodziło o indeks WIG20) prowadzone były dotąd - według wiedzy autora - sporadycznie i dotyczyły wyłącznie stóp zwrotu. Trzykrotnie tematem tym zajął się Hońdo. W 2010 r. przeanalizował on m.in. kursy akcji 12 spółek, które opuściły portfel indeksu WIG20 w latach 2005-2010 i stwierdzi1, że $3 / 4 \mathrm{Z}$ nich w ciągu roku od tego zdarzenia zachowywało się gorzej od indeksu. Średnia zmiana notowań badanych podmiotów okazała się jednak znacznie lepsza od zmiany indeksu WIG20 (25\% vs. 9\%), co autor tłumaczył faktem zniekształcenia wyników przez dwie spółki (Hońdo, 2010). W kolejnym badaniu porównał on półroczne i roczne stopy zwrotu akcji 14 spółek (wraz z dywidendami), które w latach 2009-2014 zostały wykluczone z indeksu WIG20, ze stopami zwrotu indeksu WIG20 TR (dochodowa wersja indeksu WIG20) w tych samych okresach. W krótszym okresie 57\% spółek osiągnęło stopę zwrotu wyższą od indeksu, a średnia różnica (mediana) w stopach zwrotu wyniosła $+4,1$ pkt proc. W horyzoncie rocznym natomiast tylko $36 \%$ firm okazało się lepszych od indeksu, a średnia mediana różnic w stopach zwrotu wyniosła $-5,1$ pkt proc. Wyniki te skłoniły autora do sformułowania wniosku, iż w akcje spółek usuwanych z indeksu WIG20 warto inwestować „raczej krót- 
koterminowo, z nadzieją na odreagowanie spadków, które wcześniej doprowadzity do degradacji danej firmy w hierarchii indeksowej”, pod warunkiem starannej selekcji (opierając się na analizie fundamentalnej) (Hońdo, 2015). Zbliżone rezultaty przyniosła analiza przeprowadzona rok później na próbie 17 spółek. 59\% firm w okresie pół roku po ekskluzji z indeksu WIG20 oraz $41 \%$ w okresie roku po tym fakcie osiągnęło stopę zwrotu wyższą od indeksu WIG20 TR, a różnice w stopach zwrotu akcji tych firm względem WIG20 TR (mediana) wyniosły odpowiednio $+6,1$ pkt proc. i $-3,2$ pkt proc. (Hońdo, $2016)^{3}$.

\section{Metody badawcze}

Badanie stóp zwrotu akcji spółek usuniętych z portfela indeksu podczas jego okresowych (kwartalnych i rocznych) lub nadzwyczajnych korekt (rewizji) objęło 250 dni sesyjnych (co w przybliżeniu odpowiada okresowi jednego roku kalendarzowego), poczynając od pierwszego dnia sesyjnego, w którym akcje spółki przestały być uczestnikami indeksu WIG20, kończąc zaś na 250. dniu sesyjnym od tego momentu (okres badawczy 1). Badanie zostało przeprowadzone przy zastosowaniu siły relatywnej (relative strength) dziennych zmian kursów akcji $n$ spółek w odniesieniu do indeksu WIG20. Miało to za zadanie wyeliminowanie wpływu na kursy akcji ogólnej koniunktury panującej w segmencie największych (biorąc pod uwagę kapitalizację rynkową z uwzględnieniem free float ' $u$ ) i najpłynniejszych firm notowanych na GPW w Warszawie. Posłużono się w tym celu indeksem cenowym ${ }^{4}$, który został obliczony jako średnia arytmetyczna (nieważona - udział każdej spółki w indeksie był identyczny ${ }^{5}$ ) sumy wskaźników siły relatywnej badanych spółek. Wskaźnik siły relatywnej każdej spółki w dniu $t$ był z kolei ilorazem jej kursu zamknięcia i wartości indeksu WIG20 na zamknięcie sesji w tym dniu6 . Ilustruje to poniższy wzór:

3 Badaniem krótkookresowego efektu indeksowego zajmowali się także: Wiśniewski (2002)

- dotyczyło ono zmian portfela indeksu WIG20 w latach 1998-2001 oraz Grugul (2012)

- dotyczyło zmian tego samego indeksu od początku 1995 r. do czerwca 2005 r. (analizy te obejmowały okres, odpowiednio, 5 tygodni i 20 sesji po wykluczeniu spółki z indeksu).

$4 \quad$ W obliczeniach zostały uwzględnione wyłącznie zmiany cen akcji spółek (podobnie jak ma to miejsce w indeksie WIG20), nie uwzględniono natomiast innych dochodów wynikających z posiadania akcji.

5 Rozwiązanie takie podyktowane było faktem, iż celem analizy była wyłącznie ocena zachowania się kursów akcji po ich usunięciu z indeksu niezależnie od ich właściwości (np. kapitalizacji rynkowej) - ich uwzględnienie z pewnością miałoby istotne walory poznawcze, jednak z uwagi na ograniczoną objętość artykułu nie stało się przedmiotem rozważań autora.

6 Metodologia badawcza wzorowana na pracy: Bałtowski i Kwit (2002). 


$$
P I_{t}=\frac{\sum_{n=1}^{N} \frac{P_{n, t}}{W I G 20_{t}}}{N},
$$

gdzie:

$P_{t} \quad$ - indeks cenowy (price index) badanych spółek w dniu $t$,

$N \quad$ - liczba badanych spółek wchodzących w skład indeksu,

$n \quad$ - numer kolejnej spółki wchodzącej w skład indeksu,

$P_{n, t} \quad-$ kurs akcji spółki $n$ w dniu $t$,

$W I G 20_{t}$ - wartość indeksu WIG20 w dniu $t$,

$t \quad-$ kolejne dni notowań.

Wartości wskaźnika siły relatywnej każdej ze spółek w pierwszym dniu analizowanego okresu nadano wartość 100 punktów w celu normalizacji danych. W konsekwencji także indeks cenowy wszystkich firm w pierwszym dniu po ich wykluczeniu z indeksu WIG20 przyjął wartość 100 punktów, co ułatwiło analizowanie jego zmian podczas kolejnych sesji giełdowych.

Analiza zmian płynności akcji spółek po ich wykluczeniu z indeksu WIG20 została dokonana na podstawie wybranych miar płynności (liquidity measures) w wyniku porównania ich średniej wartości (dziennej) w okresie badawczym 1 (250 sesyjnych po usunięciu akcji spółki z indeksu WIG20) ze średnią wartością w okresie badawczym 2 (250 dni sesyjnych przed ekskluzją z indeksu WIG20). W tym celu wykorzystano dwie proste miary płynności (nazywane również miarami aktywności handlowej lub transakcyjnej (trading activity measures)): liczbę przeprowadzonych transakcji oraz wolumen obrotu. Dla każdej spółki obliczono najpierw średnią dzienną wartość ww. miar w poszczególnych okresach, a następnie obliczono procentową zmianę średniej dziennej liczby transakcji oraz średniego dziennego wolumenu obrotów pomiędzy okresem badawczym 1 i okresem badawczym 2. Ponadto posłużono się prawdopodobnie najczęściej stosowaną miarą płynności akcji (ze względu na słabe skorelowanie $\mathrm{z}$ wartością rynkową spółki i nieobciążenie efektem wielkości spółki), tj. wskaźnikiem względnego wolumenu (wskaźnikiem obrotu) w ujęciu rocznym (Olbryś, 2013). W ujęciu procentowym wyraża się on wzorem:

$$
T R=\frac{T V S T}{T N S O} \cdot 100 \%,
$$

gdzie:

$T R$ - wskaźnik względnego wolumenu (wskaźnik obrotu) (turnover ratio), 
TNST - całkowity wolumen obrotu akcjami (total volume of shares traded) spółki w analizowanym okresie,

TNSO - łączna liczba wyemitowanych akcji (total number of shares outstanding) (średnia w analizowanym okresie).

Powyższy wskaźnik obliczono zarówno dla rocznego okresu badawczego 2 (tj. przed usunięciem spółki z indeksu WIG20), jak i dla rocznego okresu badawczego 1 (tj. po usunięciu spółki z indeksu) oraz porównano jego wartości w obu okresach. W przypadku spółek, w których dochodziło w analizowanych okresach do zmian liczby wyemitowanych akcji (na skutek wyemitowania nowych lub umorzenia części „starych” akcji), w celu precyzyjnego obliczenia średniej liczby akcji dostępnych dla inwestorów w danym okresie wykorzystano informacje dotyczące ww. zdarzeń? 7 .

\section{Próba badawcza i źródła danych}

W niniejszym punkcie zaprezentowano proces wyboru spółek do próby badawczej, charakterystykę tych spółek (pod kątem planowanej analizy) oraz omówiono źródła danych wykorzystanych w badaniu.

Badanie objęło okres blisko 10 lat (od początku 2007 r. do końca października 2016 r.) i dotyczyło wszystkich wydarzeń, których rezultatem było wykluczenie akcji spółki z portfela indeksu WIG20. W analizowanym okresie doszło do 39 zdarzeń, których konsekwencją mogła potencjalnie być zmiana składu indeksu WIG20 (10 rewizji rocznych i 29 korekt kwartalnych) oraz do 14 korekt nadzwyczajnych ww. indeksu. Spośród wszystkich ww. zdarzeń jedynie w 18 przypadkach doszło do wykluczenia akcji spółki (spółek) z portfela indeksu WIG20 - dziesięciokrotnie podczas rewizji rocznej, sześciokrotnie w czasie korekty kwartalnej oraz dwukrotnie w momencie przeprowadzania korekty nadzwyczajnej. Bliższą charakterystykę tych zdarzeń prezentuje tabela 1 .

7 Zazwyczaj w tego rodzaju obliczeniach średnią liczbę wyemitowanych akcji uzyskuje się poprzez obliczenie średniej arytmetycznej z danych na początku i na końcu badanego okresu, jednak nie jest to precyzyjna metoda obliczeń, zwłaszcza przy znaczącej emisji (umorzeniu) akcji na początku lub na końcu okresu. 
Ta b e l a 1. Zmiany w składzie indeksu WIG20 w okresie od 1 stycznia 2007 r. do 31 października 2016 r., w następstwie których nastąpiło wykluczenie akcji spółki (spółek) z indeksu

\begin{tabular}{|c|c|c|c|c|}
\hline Lp. & Rodzaj zmiany & $\begin{array}{c}\text { Data } \\
\text { dokonania } \\
\text { zmiany }^{*}\end{array}$ & $\begin{array}{l}\text { Spółki wykluczone } \\
\text { z portfela indeksu } \\
\text { WIG20** }\end{array}$ & $\begin{array}{l}\text { Indeks, do którego portfela trafiły } \\
\text { akcje spółki po ich usunięciu } \\
\text { z indeksu WIG20 }\end{array}$ \\
\hline 1. & Rewizja roczna & 16.03 .2007 & Kęty & mWIG40 \\
\hline 2. & Korekta kwartalna & 15.06 .2007 & Netia & mWIG40 \\
\hline 3. & Korekta kwartalna & 21.09 .2007 & MOL & - \\
\hline 4. & Rewizja roczna & 20.03 .2008 & $\begin{array}{l}\text { Bank BPH } \\
\text { Prokom }\end{array}$ & $\begin{array}{l}\mathrm{mWIG} 40 \\
\mathrm{mWIG} 40\end{array}$ \\
\hline 5. & Rewizja roczna & 20.03 .2009 & Polnord & mWIG40 \\
\hline 6. & Rewizja roczna & 19.03 .2010 & Agora & mWIG40 \\
\hline 7. & $\begin{array}{l}\text { Korekta } \\
\text { nadzwyczajna*** }^{*}\end{array}$ & 14.05 .2010 & Cersanit & mWIG40 \\
\hline 8. & Korekta kwartalna & 17.12 .2010 & Bioton & mWIG40 \\
\hline 9. & Rewizja roczna & 18.03 .2011 & $\begin{array}{l}\text { Cyfrowy Polsat } \\
\text { Polimex Mostostal }\end{array}$ & $\begin{array}{l}\mathrm{mWIG} 40 \\
\mathrm{mWIG} 40\end{array}$ \\
\hline 10. & $\begin{array}{l}\text { Korekta } \\
\text { nadzwyczajna**** }^{* *}\end{array}$ & 5.04.2011 & BZ WBK & - \\
\hline 11. & Korekta kwartalna & 16.09 .2011 & CEZ & - \\
\hline 12. & Rewizja roczna & 16.03 .2012 & $\begin{array}{l}\text { Getin } \\
\text { PBG }\end{array}$ & $\begin{array}{l}\mathrm{mWIG} 40 \\
\mathrm{mWIG} 40\end{array}$ \\
\hline 13. & Rewizja roczna & 15.03 .2013 & TVN & mWIG40 \\
\hline 14. & Korekta kwartalna & 21.06 .2013 & Boryszew & mWIG40 \\
\hline 15. & Rewizja roczna & 21.03 .2014 & $\begin{array}{l}\text { GTC } \\
\text { Bank Handlowy }\end{array}$ & $\begin{array}{l}\mathrm{mWIG} 40 \\
\mathrm{mWIG} 40\end{array}$ \\
\hline 16. & Rewizja roczna & 20.03 .2015 & $\begin{array}{l}\text { JSW } \\
\text { Kernel } \\
\text { Lotos }\end{array}$ & $\begin{array}{l}\mathrm{mWIG} 40 \\
\mathrm{mWIG} 40 \\
\mathrm{mWIG} 40\end{array}$ \\
\hline 17. & Korekta kwartalna & 18.12 .2015 & Bogdanka & mWIG40 \\
\hline 18. & Rewizja roczna & 18.03 .2016 & Synthos & mWIG40 \\
\hline
\end{tabular}

* dzień, po którym przeprowadzono zmianę w portfelu indeksu WIG20,

** nazwa spółki obowiązująca w momencie wykluczenia z indeksu,

*** korekta nadzwyczajna wynikała z debiutu akcji spółki PZU S.A., dla której wartość akcji w wolnym obrocie w dniu pierwszego notowania (12.05.2010) stanowiła ponad 5\% wartości kapitalizacji portfela indeksu WIG20 na sesji w tym dniu,

**** korekta nadzwyczajna wynikała ze spadku liczby akcji w wolnym obrocie spółki BZ WBK S.A. poniżej 10\% w rezultacie nabycia 69,9 mln akcji przez Bank Santander w wyniku wezwania (w efekcie Santander przejął ponad $95 \%$ akcji BZ WBK).

Źródło: opracowanie własne.

W ramach 18 zdarzeń wyszczególnionych w tabeli 1 portfel indeksu giełdowych blue-chipów opuściły łącznie akcje 24 spółek. W zdecydowanej większo- 
ści przypadków trafiły one - w efekcie spadku w rankingu indeksów WIG20, mWIG40 i sWIG80 (zgodnie z metodologią giełdową) - do portfela indeksu mWIG40. Jednak w przypadku trzech spółek (MOL, BZ WBK i CEZ) ich akcje $-\mathrm{z}$ różnych względów ${ }^{8}$ - po ekskluzji z indeksu WIG20 nie zostały zakwalifikowane do żadnego innego indeksu warszawskiej giełdy.

Spośród 24 wyselekcjonowanych spółek przedmiotem analizy stały się 23 podmioty (wyjątkiem okazała się spółka Prokom, której walory 8 dni po wykluczeniu z indeksu uległy delistingowi w wyniku włączenia jej do Asseco Poland). W przypadku dwóch kolejnych firm (Bogdanka i Synthos), z uwagi na stosunkowo niedawne opuszczenie przez nie indeksu WIG20 (odpowiednio w grudniu 2015 r. i marcu 2016 r.), okres badawczy 1 okazał się nieco krótszy niż w pozostałych spółkach (odpowiednio 216 i 156 sesji).

W badaniu wykorzystano następujące rodzaje danych: kursy zamknięcia akcji spółek, wartości indeksu WIG20 na zamknięciu sesji, wolumen obrotów akcjami spółek oraz liczbę przeprowadzonych transakcji tymi akcjami (we wszystkich przypadkach dotyczyło to danych dziennych). Źródłem powyższych danych był serwis GPW Infostrefa. Dane na temat liczby akcji wyemitowanych przez badane podmioty zostały pozyskane z roczników giełdowych i biuletynów miesięcznych GPW w Warszawie oraz z informacji dotyczących emisji i umorzeń akcji publikowanych na stronach internetowych analizowanych firm.

\section{Wyniki}

Wyniki pierwszej części badania okazały się dość zaskakujące. Rok po wykluczeniu spółek z indeksu WIG20 ich indeks siły relatywnej zniżkował jedynie o $4,26 \%$, przy czym wynik ten byłby prawdopodobnie zbliżony do zera, gdyby dostępne były wszystkie notowania akcji spółek Bogdanka i Synthos. Analiza zachowania się indeksu w całym okresie obserwacji 1 wykazała, iż generalnie oscylował on wokół poziomu wyjściowego (tj. poziomu 100 punktów), amplituda jego wahań była zaś relatywnie niewielka (wyniosła 12,3 pkt) (rys. 1). Indeks siły relatywnej przyjmował wartości poniżej 100 pkt przez $46 \%$ badanego okresu (głównie od 23. do 128. i od 215. do ostatniego dnia tego okresu), natomiast przez pozostałe $54 \%$ czasu jego wartość przekraczała 100 pkt. W okresie roku po wykluczeniu spółek z indeksu trudno było dopatrzyć się jakiegokolwiek choćby średnioterminowego trendu - jedynie dwukrotnie można było zaobserwować krótkoterminowe trendy rosnące (od 1. do 12.

8 W rankingu indeksów WIG20, mWIG40 i sWIG80 nie uczestniczą m.in. spółki, w przypadku których liczba akcji w wolnym obrocie jest mniejsza od $10 \%$ oraz znajdujące się w szczególnej sytuacji. 
i od 126. do 149. dnia obserwacji) i krótkoterminowe trendy spadkowe (od 13. do 24 . i od 150. do 161. dnia obserwacji) ${ }^{9}$.

Ry s u n e k 1. Indeks siły relatywnej badanych spółek w okresie obserwacji 1

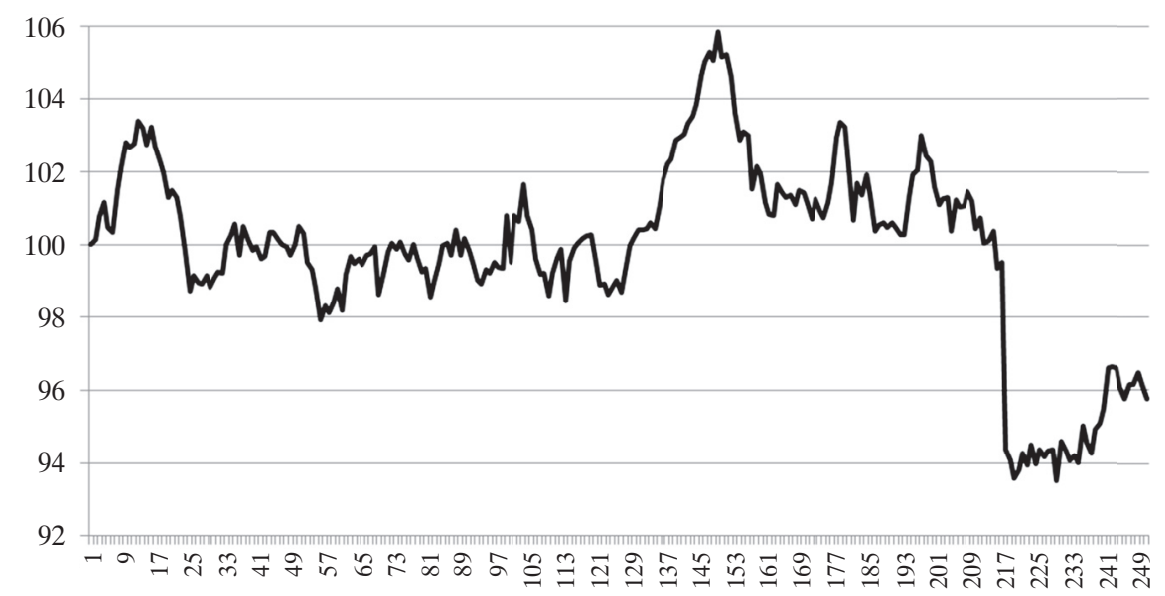

Źródło: opracowanie własne.

Obraz stosunkowo niewielkiej średniej zmiany stóp zwrotu akcji spółek względem indeksu WIG20 po roku od ich wykluczenia $\mathrm{z}$ tego indeksu należy jednak skonfrontować z rezultatami dla poszczególnych firm będących przedmiotem badania (tab. 2). Ogółem w gronie 23 podmiotów 12 odnotowało ujemną wartość wskaźnika siły relatywnej, a 11 - dodatnią. Warto zwrócić uwagę, iż jedynie w przypadku sześciu spółek zmiana ww. wskaźnika na koniec okresu obserwacji 1 nie przekraczała $+/-10 \%$, natomiast w pozostałych była $\mathrm{z}$ reguły kilkukrotnie większa (w tym sześciokrotnie przekraczała $+/-40 \%$ ). Największy dodatni wskaźnik siły relatywnej zaobserwowano w przypadku akcji spółek Bogdanka, Kernel i TVN, natomiast najmniejszy w przypadku akcji spółek PBG, Polimex Mostostal i Bioton. Ogromne zróżnicowanie wyników poszczególnych firm potwierdza również wielkość rozstępu - różnica pomiędzy najlepszą i najgorszą spółką wyniosła aż 201,5 pkt proc.

$9 \quad$ Widoczny na rys. 1 gwałtowny spadek wartości indeksu w 217. dniu obserwacji spowodowany został wyłączeniem w tym dniu, z uwagi na brak danych, z badanej próby spółki Bogdanka (badanie zostało zakończone 31.10.2016 r. - na półtora miesiąca przed końcem okresem obserwacji dla tej spółki). 
Ta b e l a 2. Wskaźniki siły relatywnej badanych spółek (w stosunku do indeksu WIG20) na koniec okresu badawczego 1

\begin{tabular}{|c|c|c|c|c|c|}
\hline Lp. & Spótka* & Siła relatywna $(\%)$ & Lp. & Spółka ${ }^{*}$ & Siła relatywna $(\%)$ \\
\hline 1. & Kęty & $-29,89$ & 13. & Getin & 9,30 \\
\hline 2. & Netia & $-5,08$ & 14. & PBG & $-86,24$ \\
\hline 3. & $\mathrm{MOL}$ & $-21,39$ & 15. & TVN & $\begin{array}{ll}68,99 \\
\end{array}$ \\
\hline 4. & Bank BPH & $-32,30$ & 16. & Boryszew & 25,73 \\
\hline 5. & Polnord & 1,36 & 17. & GTC & $-28,81$ \\
\hline 6. & Agora & $-2,61$ & 18. & Bank Handlowy & 4,68 \\
\hline 7. & Cersanit & $-29,46$ & 19. & JSW & $-20,76$ \\
\hline 8. & Bioton & $-44,51$ & 20. & Kernel & 85,22 \\
\hline 9. & Cyfrowy Polsat & 11,71 & 21. & Lotos & 26,66 \\
\hline 10. & $\begin{array}{l}\text { Polimex } \\
\text { Mostostal } \\
\end{array}$ & $-47,84$ & 22. & Bogdanka** & 115,28 \\
\hline 11. & BZ WBK & 32,14 & 23. & Synthos ${ }^{* * *}$ & 37,85 \\
\hline 12. & CEZ & $-6,26$ & & & \\
\hline
\end{tabular}

* nazwa spółki obowiązująca w momencie wykluczenia z indeksu,

** dane na koniec 216. sesji po wykluczeniu spółki z indeksu,

*** dane na koniec 156. sesji po wykluczeniu spółki z indeksu.

Źródło: opracowanie własne.

Uzyskane rezultaty nie pozwalają zatem na sformułowanie jednoznacznych wniosków dotyczących zachowania się kursów akcji spółek usuniętych z indeksu WIG20 w okresie roku po tym wydarzeniu. Brak jednoznacznego trendu w analizowanym okresie oraz ogromne dysproporcje pomiędzy spółkami sugerują jednak, iż jak dotychczas w długim terminie wśród giełdowych blue-chipów notowanych na GPW w Warszawie nie pojawił się wyraźny i jednoznaczny efekt indeksowy w postaci spadku kursów akcji spółek, które opuściły portfel indeksu WIG20. Można przypuszczać, iż zmiany cen ich akcji były spowodowane innymi czynnikami, głównie o charakterze fundamentalnym. Przyczyny niewystąpienia ww. efektu można próbować wyjaśnić dwojako: znaczenie pasywnych inwestorów (krajowych i zagranicznych) na polskim rynku akcji jest znikome bądź też efekt indeksowy ma charakter wybitnie krótkookresowy i występuje nie po ekskluzji spółki z indeksu, lecz wcześniej - w momencie ogłoszenia informacji o tego rodzaju planowanym posunięciu.

Rezultaty drugiej części badania były natomiast zasadniczo zgodne z wynikami podobnych badań na rynkach zagranicznych. Niezależnie od zastosowanej w badaniu miary, płynność akcji (aktywność transakcyjna) większości spółek opuszczających indeks WIG20 w okresie roku po tej zmianie okazała się niższa (często zdecydowanie niższa) niż w okresie roku przed wykluczeniem $\mathrm{z}$ tego indeksu (tab. 3). Najdobitniej zjawisko to można było zaobserwować w przy- 
padku średniej dziennej liczby transakcji - aż dwudziestokrotnie liczba ta uległa zmniejszeniu (od 10,2 do 92,9\%), a jedynie w trzech spółkach odnotowano jej wzrost (od 12,3 do 63,7\%). Średni dzienny wolumen obrotów zmniejszył się w przypadku 15 badanych firm (od 6,5 do 96,0\%), zwiększył się zaś w ośmiu podmiotach (od 1,9 do 338,3\%). Z kolei wskaźnik obrotu zmalał w 15 spółkach (od 1,1 do 52,2 pkt proc.), a wzrósł tylko w pięciu (od 4,5 do 485,3 pkt proc.) ${ }^{10}$.

Analiza danych dotyczących poszczególnych spółek wskazuje, iż spadek płynności przybierał często ogromne rozmiary - średnia dzienna liczba transakcji w aż 13 podmiotach spadła o ponad 50\%, a w przypadku średniego dziennego wolumenu sytuacja taka zdarzyła się dziesięciokrotnie. Największa redukcja płynności (rzędu 70-90\% w przypadku dwóch pierwszych miar) wystąpiła w przypadku MOL, BZ WBK i CEZ, czyli firm których akcje po usunięciu z portfela WIG20 przestawałyby być uczestnikami jakiegokolwiek indeksu obliczanego przez GPW w Warszawie (w przypadku pozostałych badanych firm trafiały one do indeksu mWIG40) (por. tab. 1). Analogicznie jak w przypadku siły relatywnej, także i w odniesieniu do płynności charakterystyczne były duże dysproporcje pomiędzy badanymi spółkami - obok firm, które doświadczyły znaczącego ograniczenia aktywności ze strony inwestorów, znalazły się też takie (np. PBG, Lotos), które odnotowały wzrost płynności. Na marginesie wcześniejszych rozważań warto także zauważyć, iż po usunięciu z indeksu WIG20 w przypadku większości badanych podmiotów (17 na 23) zwiększyła się średnia wielkość (wolumen) transakcji. Oznaczać to może, iż spółki wykluczone z indeksu zaczęły się cieszyć relatywnie większym niż wcześniej zainteresowaniem inwestorów o zasobniejszych portfelach (czyli głównie inwestorów instytucjonalnych). Być może wyjaśnieniem tego zjawiska jest fakt, iż akcje tych firm pozostawały nadal w kręgu zainteresowań niektórych podmiotów z tej kategorii, stawały się bowiem zazwyczaj istotnymi uczestnikami indeksu mWIG40 (lub pozostawały w indeksie WIG30).

Niewątpliwie znaczący spadek aktywności transakcyjnej zdecydowanej większości spółek opuszczających indeks WIG20 potwierdza obserwowany od wielu lat fakt, iż wielu inwestorów (głównie zagranicznych ${ }^{11}$ ) skupia swoją uwagę wyłącznie na tym segmencie warszawskiej giełdy (według danych GPW średni udział spółek należących do tego indeksu w obrotach akcjami na Głów-

10 Wskaźnik obrotu obliczono ogółem dla 20 spółek, gdyż w przypadku trzech pozostałych zabrakło porównywalnych okresów obserwacji.

11 Zagraniczni inwestorzy zdecydowanie dominują w statystykach dotyczących udziału poszczególnych grup inwestorów w obrotach akcjami na Głównym Rynku - według danych GPW w 2015 r. ich udział przekroczył po raz pierwszy 50\% i nadal wykazuje tendencję rosnącą (w I półroczu 2016 r. wyniósł 54\%). 
nym Rynku w latach 2011-2015 wyniósł aż 79,3\%). Konsekwencją wykluczenia $\mathrm{z}$ indeksu są wyższe koszty przeprowadzania transakcji w postaci m.in. większego spreadu oraz większe trudności w szybkim zamykaniu pozycji, co na ogół skutecznie zniechęca istotną część instytucji finansowych do aktywnego dokonywania transakcji walorami takich firm. Akcjami tych spółek zaczynają się natomiast w większym stopniu interesować ci inwestorzy, którzy poszukują okazji inwestycyjnych wśród firm o średniej kapitalizacji - w tym gronie znajdują się zarówno krajowe fundusze inwestycyjne wyspecjalizowane w lokowaniu kapitału w walorach polskich małych i średnich firm (według danych IZFiA w końcu września 2016 r. funkcjonowało w Polsce 20 takich funduszy o łącznych aktywach netto w wysokości 2,75 mld zł), jak i część inwestorów indywidualnych.

\section{Zakończenie}

Badanie trwałego efektu indeksowego wśród spółek notowanych na GPW w Warszawie, których akcje zostały wykluczone z portfela indeksu WIG20 w latach 2007-2016, przyniosło niejednoznaczne wyniki. W przypadku analizy stóp zwrotu $52 \%$ badanych firm osiągnęło po roku od ekskluzji ujemną wartość wskaźnika siły relatywnej (względem indeksu WIG20), natomiast dla 48\% spółek wskaźnik ten przyjął wartość dodatnią. Indeks siły relatywnej wszystkich 23 analizowanych podmiotów zniżkował na koniec badanego okresu tylko o 4,3\%, jednak różnice pomiędzy poszczególnymi spółkami były bardzo duże. $\mathrm{Na}$ tej podstawie trudno zatem formułować jednoznaczny wniosek odnośnie do zachowania kursów akcji spółek po ich usunięciu z indeksu blue-chipów. Wydaje się, że każdy przypadek należy w tego rodzaju sytuacji traktować indywidualnie i, próbując wykorzystać wiedzę na ten temat do budowania strategii inwestycyjnej, należy włączyć do analizy także inne czynniki, które mogą determinować notowania tych walorów.

Całkowicie inaczej prezentują się natomiast rezultaty badania odnoszącego się do płynności (aktywności transakcyjnej) akcji spółek opuszczających indeks WIG20. Wszystkie przeanalizowane miary jednoznacznie potwierdziły hipotezę o niższej płynności tych papierów wartościowych. W największym stopniu dotyczyło to tych spółek, które po usunięciu z indeksu WIG20 nie zostały włączone ani do portfela indeksu mWIG40, ani do portfela żadnego innego indeksu obliczanego przez warszawską giełdę (z uwagi na niespełnianie kryteriów bazowych). Znaczący spadek liczby transakcji, wolumenu czy też wskaźnika obrotu jest niewątpliwie zjawiskiem niekorzystnym, którego konsekwencją może być wzrost ryzyka rynkowego oraz kosztów transakcyjnych (analiza tego rodzaju zjawisk powinna stać się przedmiotem dalszych badań). 


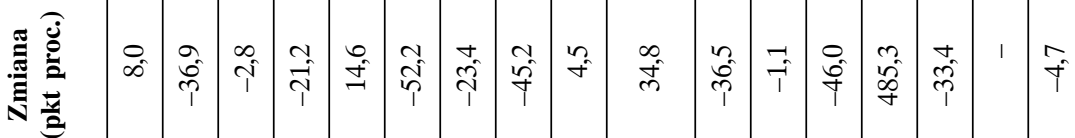

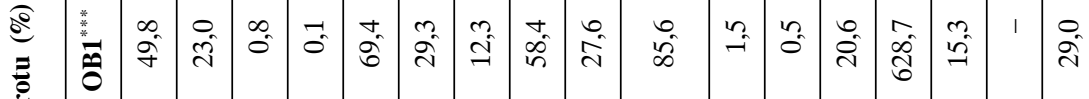

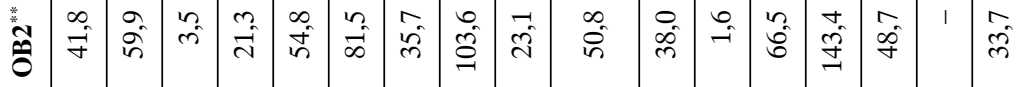

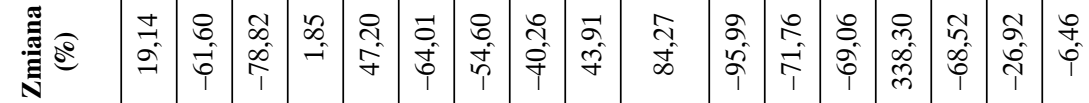

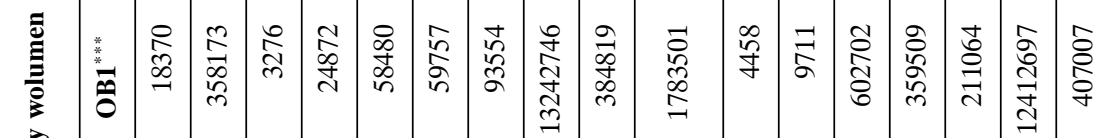

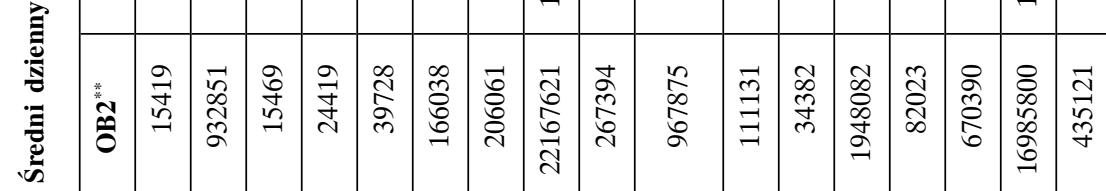

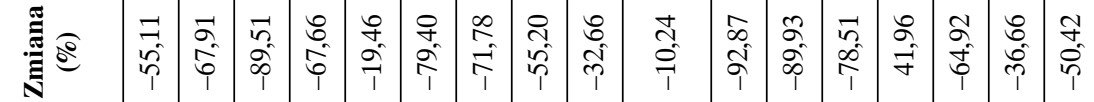

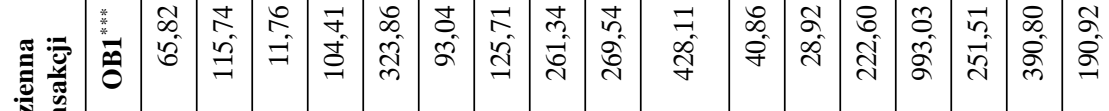

犗

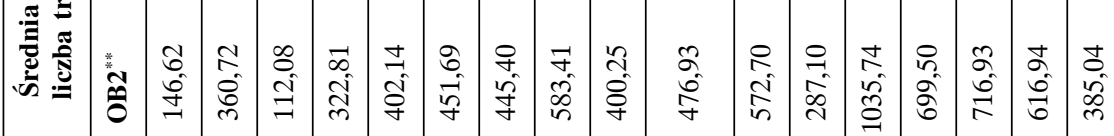

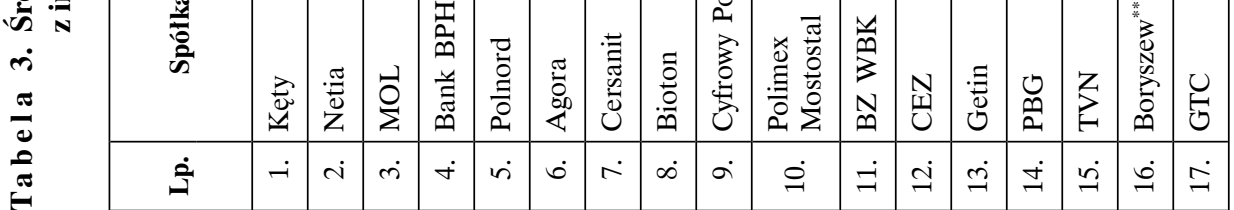




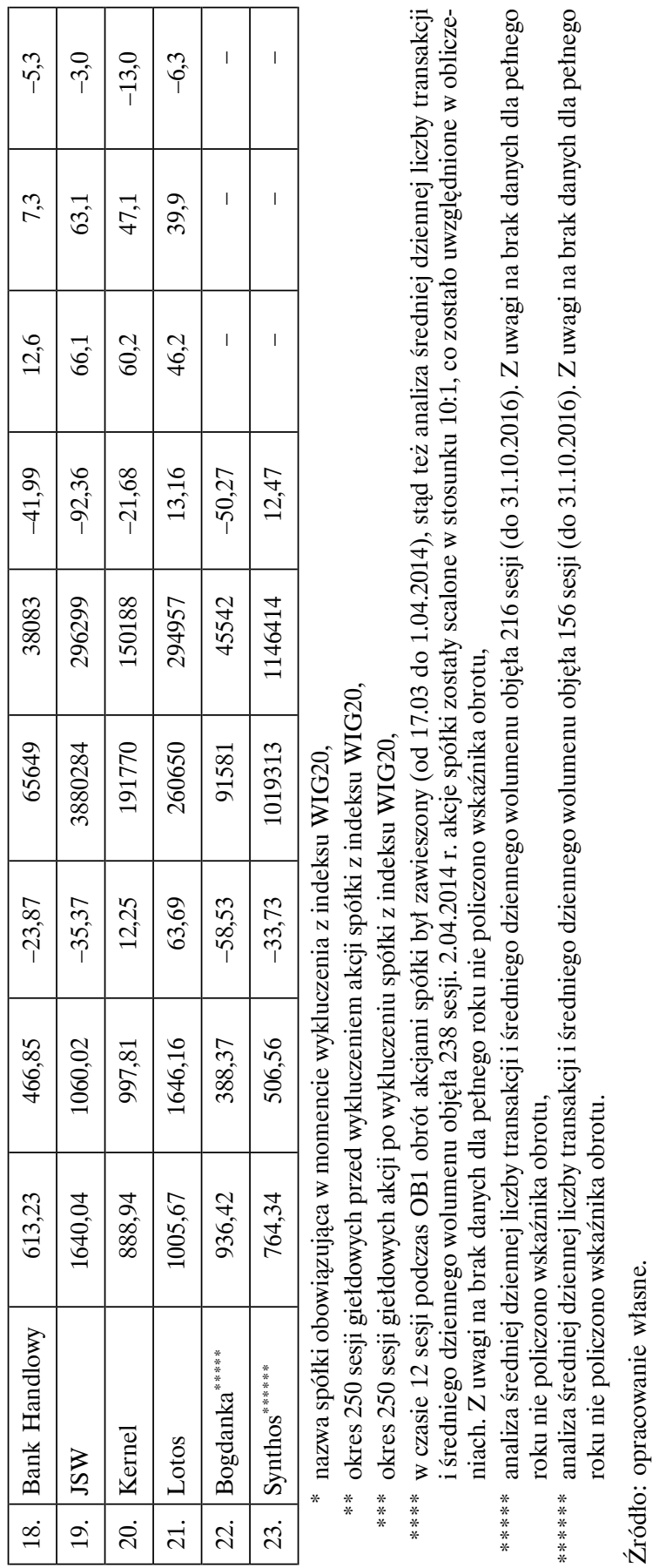




\section{Bibliografia}

Azevedo, A., Karim, M., Gregoriou, A. i Rhodes, M. (2014). Stock price and volume effects associated with changes in the composition of FTSE Bursa Malaysian KLCI. Journal of International Financial Markets, Institutions and Money, 28, 20-35, http://dx.doi. org/10.1016/j.intfin.2013.10.001.

Bałtowski, M. i Kwit, J. (2002). Wycena przez rynek kapitałowy przedsiębiorstw sprywatyzowanych. W: M. Bałtowski (red.), Przedsiębiorstwa sprywatyzowane w gospodarce polskiej. Warszawa: PWN.

Beneish, M.D. i Whaley, R.E. (1996). An Anatomy of the "S \& P Game": The Effect of Changing the Rules. Journal of Finance, 51(5), 1909-1930.

Bildik, R. i Gülay, G. (2008). The effects of changes in index composition on stock prices and volume: Evidence from the Istanbul Stock Exchange. International Review of Financial Analysis, 17, 178-197.

Brealey, R.A. (2000). Stock prices, stock indexes and index funds. Bank of England Quarterly Bulletin, February, 61-68.

Breazeale, J.P. i Cuny, C.J. (2002). Stock Price Effects of Changes in the S\&P MidCap 400 and the S\&P SmallCap 600 Indices. Working paper, Texas A\&M University.

Calafiore, P.J. i Jackson, D. (2008). The effects on index composition changes on stock prices in Argentina. Journal of Current Research in Global Business, 11(2), 19-35.

Chung, R. i Kryzanowski, L. (1998). Are the Market Effects Associated with Revisions to the TSE300 Index Robust? Multinational Finance Journal, 2(1), 1-37.

Dhillon, U. i Johnson, H. (1991). Changes in the Standard \& Poor`s 500 list. The Journal of Business, 64(1), 75-85, http://dx.doi.org/10.1086/296526.

Elayan, F., Li, W. i Pinfold, J. (2001). Price Effects of Changes to the Composition of New Zealand Shares Indices. The New Zealand Investment Analyst, 21, 25-30.

Gomez Sala, J.C i Yzaguirre, J. (2003). Presión sobre los precios en las revisiones del índice IBEX35. Investigaciones Economicas, 27(3), 491-531.

Gurgul, H. (2012). Analiza zdarzeń na rynkach akcji. Wplyw informacji na ceny papierów wartościowych (wyd. II). Warszawa: Wolters Kluwer Polska.

Harris, L. i Gurel, E. (1986). Price and Volume Effects Associated with Changes in the S\&P 500 List: New Evidence for the Existence of Price Pressure. Journal of Finance, 41, 815-829, http://dx.doi.org/10.2307/2328230.

He, Y. i Wang, Z. (2015). The Empirical Analysis of Index Effect in Chinese Stock Market: Based on the SHSZ 300 Index. International Journal of Business and Management, 10(5), 182-192.

Hońdo, T. (2010). Wejście do WIG20 to powód do sprzedaży akcji? Gazeta Giełdy Parkiet, 30.08.2010.

Hońdo, T. (2015). Debiut w WIG20 to powód do kupna akcji? Wręcz przeciwnie. Gazeta Gietdy Parkiet, 21.02.2015.

Hońdo, T. (2016). Wejście do WIG20 to przestroga, wyjście - zachęta do przyjrzenia się spółce. Gazeta Giełdy Parkiet, 12.03.2016.

Jain, P.C. (1987). The Effect on Stock Price of Inclusion in of Exclusion from the S\&P 500. Financial Analysts Journal, 43(1), 58V65, http://dx.doi.org/10.2469/faj.v43.n1.58.

Komunikaty zarządu GPW w Warszawie dotyczące rewizji rocznych, korekt kwartalnych i korekt nadzwyczajnych indeksu WIG20 z lat 2007-2016. 
Liu, S. (2000). Changes in the Nikkei 500: New Evidence for Downward Sloping Demand Curves for Stocks. International Review of Finance, 1, 245-267.

Nardy, A., Famá, R., de Hoyos Guevara, J. A. i Mussa, A. (2015). Verificação da ocorrência do efeito índice no Ibovespa - 2004-2013. Revista de Administração, 50(2), 153-168.

Olbryś, J. (2013). Zastosowanie wybranych miar płynności aktywów kapitałowych na Giełdzie Papierów Wartościowych w Warszawie S.A.. Zarzadzanie i Finanse, 11(3) (cz. 2), 65-77.

Schleifer, A. (1986). Do demand curves for stocks slope down? Journal of Finance, 41(3), 579-590.

Steiner, M. i Heinke, V.G. (1997). Preis- und Volumeneffekte bei Einführung des MDAX. Finanzmarkt und Portfolio Management, 11(4), 432-459.

Wiśniewski, T. (2002), Zmiany portfela WIG20. Nasz Rynek Kapitałowy, 133(1), 62-64.

Wurgler, J.A. i Zhuravskaya, E. (2002). Does arbitrage flatten demand curves for stocks? Journal of Business, 75(4), 583-608.

Yun, J.Y. i Kim, T.S. (2011). Information Content of Changes in Index Composition. AsiaPacific Journal of Financial Studies, 40(2), 317-346. 



\section{Rozdział VI}

\section{KATARZYNA DĄBROWSKA-GRUSZCZYŃSKA*}

\section{Techniki japońskie \\ w warsztacie polskiego inwestora giełdowego. Czy formacje świecowe mogą pomóc przewidzieć zmianę trendu?}

Celem artykułu jest zbadanie skuteczności formacji świec japońskich jako narzędzia przewidującego zmianę trendu. Analizę przeprowadzono na danych dziennych kontraktów terminowych futures na WIG20 w okresie styczeń 2001-październik 2016. W pierwszej części badania skupiono się na identyfikacji formacji świecowych oraz ich częstotliwości. Drugą część artykułu poświęcono analizie skuteczności zastosowania poszczególnych formacji świecowych w strategiach inwestycyjnych.

Słowa kluczowe: formacje świec japońskich, strategie inwestycyjne, analiza techniczna.

Japanese techniques in the workshop of Polish stock market investor. Can candlestick patterns help predict the trend change?

The aim of this article is to examine the effectiveness of Japanese candlestick patterns as a tool predicting the trend change. The analysis was conducted on daily data for futures contracts on the WIG20 index in the period January 2001 to October 2016. In the first part the author concentrated on identifying the Japanese candlestick patterns and their frequency of occurrence. The second part of the article was devoted to the analysis of the effectiveness of application of each Japanese candlestick pattern in investment strategies.

Keywords: Japanese candlestick patterns, investment strategies, technical analysis.

JEL: G11, G12, G17

dr Katarzyna Dąbrowska-Gruszczyńska - Katedra Bankowości, Finansów i Rachunkowości, Wydział Nauk Ekonomicznych, Uniwersytet Warszawski, ul. Długa 44/50, 00-241 Warszawa; e-mail: dabrowska@wne.uw.edu.pl. 


\section{Wprowadzenie}

Analiza techniczna jako narzędzie wspomagające decyzje inwestycyjne jest bardzo popularna wśród praktyków rynkowych. Smith, Faugere i Wang (2013) zauważyli, że ponad 30\% amerykańskich zarządzających aktywami na rynkach akcyjnych stosuje analizę techniczną. Analiza ta polega przede wszystkim na znalezieniu momentów zwrotnych na wykresach cenowych. Najważniejsza jest identyfikacja trendu, czyli kierunku, w jakim podążają ceny instrumentu. Jeśli inwestorowi udaje się dobrze rozpoznać zmianę trendu i otworzy on pozycję zgodnie z sygnałem kupna/sprzedaży, ma szansę osiągnąć sukces finansowy, zwłaszcza że trendy zazwyczaj trwają przez dłuższy czas. Wykresy świecowe oraz formacje świec japońskich należą do narzędzi stosowanych w analizie technicznej. Powstaje zatem pytanie, czy jest możliwe przewidzenie odwrócenia trendu za pomocą wykorzystania wykresów świecowych?

Celem niniejszego artykułu jest zbadanie skuteczności formacji świec japońskich jako narzędzia przewidującego zmianę trendu. Analizę przeprowadzono na danych dziennych kontraktów terminowych futures na WIG20 w okresie styczeń 2001-październik 2016. Wybór instrumentu był podyktowany względami praktycznymi z punktu widzenia polskiego inwestora giełdowego. Szukano instrumentu, który byłby dla niego dostępny na rynku krajowym, a zarazem miałby odpowiednią płynność na rynku w całym okresie badawczym.

W pierwszej części badania skupiono się na identyfikacji formacji świecowych oraz ich częstotliwości. Drugą część artykułu poświęcono analizie skuteczności zastosowania poszczególnych formacji świecowych w strategiach inwestycyjnych.

\section{Przegląd badań}

Zdania badaczy na temat użyteczności formacji świecowych na rynkach finansowych, jak zwykle w ekonomii, są podzielone. Marshall, Young i Rose (2006), analizując wykresy spółek wchodzących w skład DJIA w latach 1992-2001, pokazali, że stosowanie formacji świecowych jako strategii inwestycyjnej jest nieskuteczne. Do podobnych wniosków doszli Horton (2009) dla rynku amerykańskiego, Prado, Ferneda, Morais, Luiz i Matsura (2013) dla akcji z rynku brazylijskiego oraz Fock, Klein i Zwergel (2005) na danych intraday cen kontraktów futures na indeks niemieckiej giełdy i niemieckich obligacji skarbowych.

Jednakże Caginalp i Laurent (1998), na podstawie analizy wykresów indeksu S\&P500 w latach 1992-1996, uznali metodę świec japońskich za jedną 
z lepszych strategii inwestycyjnych. Podobnie Shiu i Lu (2011) potwierdzili skuteczność formacji świecowych dla rynku tajwańskiego. Sprawdzając siłę predykcji ośmiu formacji odwrócenia trendu, Chen, Bao i Zhou (2016) zauważyli, że pięć z nich pokazało dobry kierunek zmiany.

Większość badaczy skupia się na analizie kilku lub kilkunastu formacji świecowych. Z tego punktu widzenia prace Morrisa (1998) oraz Lemparta i Zalewskiego (2013) zasługują na szczególną uwagę. Ostatnia publikacja jest bowiem formą leksykonu świec i formacji świecowych, autorzy podają w niej także statystyki występowania i skuteczności tych narzędzi dla akcji z indeksu WIG20 oraz kontraktów terminowych na akcje i indeksy warszawskiej giełdy w latach 1999-20121.

Natomiast Morris w swojej monografii (1998) nie tylko daje precyzyjne wskazówki budowy świec japońskich oraz ich układów, lecz także przedstawia wyniki badania wiarygodności aż 64 formacji odwrócenia i kontynuacji trendu dla akcji z indeksu S\&P100 oraz 41 kontraktów terminowych. Wyniki badania Morrisa (1998) potwierdziły skuteczność niektórych z formacji świecowych, a cała analiza była i jest doskonałym punktem wyjścia dla praktyków giełdowych.

\section{Skuteczność formacji świecowych dla FW20}

\subsection{Dane i metoda badawcza}

W niniejszym artykule przeprowadzono badanie występowania formacji świecowych oraz ich skuteczności na przykładzie kontraktów terminowych futures na WIG20 (FW20) w latach 2001-2016 (3950 obserwacji dziennych). Wybór instrumentu opierał na założeniu dalszego praktycznego wykorzystania wyników badań przez inwestorów. Kontrakty FW20 są instrumentem popularnym wśród graczy giełdowych, cechuje je wysoka płynność niezbędna w analizie technicznej. W badaniu wykorzystano dane FW20 zaczerpnięte ze strony internetowej bossa.pl. Ze względu na okresowość i różnorodność serii notowań kontraktów terminowych publikowany FW20 jest syntetycznym instrumentem obejmującym notowania najbliżej wygasającego kontraktu terminowego. W sytuacji wygasania kontraktu notowania jego są zastępowane danymi z kontraktów terminowych nowej serii, w momencie gdy obroty tego drugiego przewyższają serię wygasającą. W ten sposób osiąga się ciągłość notowań FW20.

\footnotetext{
Ze względu na przyjęcie innych zasad identyfikowania świec i trendu, jak również przyjęcie innych założeń przy analizie skuteczności formacji nie można bezpośrednio porównać rezultatów badania Lemparta i Zalewskiego (2013) z wynikami niniejszego artykułu.
} 
Tabela 1. Formacje świecowe i ich hipotezy (*)

\begin{tabular}{|c|c|c|c|c|}
\hline Lp. & Nazwa formacji & $\begin{array}{l}\text { Liczba świec } \\
\text { w formacji }\end{array}$ & Trend przed & Hipoteza \\
\hline 1. & $\begin{array}{l}\text { Dno trzech rzek } \\
\text { (Unique Three River Bottom) }+\end{array}$ & 3 & spadkowy & trend wzrostowy \\
\hline 2. & Dwa kruki (Two Crows) - & 3 & wzrostowy & trend spadkowy \\
\hline 3. & Dwa kruki i luka (Upside Gap Two Crows) - & 3 & wzrostowy & trend spadkowy \\
\hline 4. & Gołąb (Pigeon) + & 2 & spadkowy & trend wzrostowy \\
\hline 5. & Gwiazda doji (Doji Star) + & 2 & spadkowy & trend wzrostowy \\
\hline 6. & Gwiazda poranna (Morning Star) + & 3 & spadkowy & trend wzrostowy \\
\hline 7. & Gwiazda wieczorna (Evening Star) - & 3 & wzrostowy & trend spadkowy \\
\hline 8. & Gwiazda wieczorna doji (Evening Doji Star) - & 3 & wzrostowy & trend spadkowy \\
\hline 9. & Harami - & 2 & wzrostowy & trend spadkowy \\
\hline 10. & Harami + & 2 & spadkowy & trend wzrostowy \\
\hline 11. & Kanapka (Stick Sandwich) + & 3 & spadkowy & trend wzrostowy \\
\hline 12. & Młot $($ Hammer $)+$ & 1 & spadkowy & trend wzrostowy \\
\hline 13. & Narada (Deliberation) - & 3 & wzrostowy & trend spadkowy \\
\hline 14. & Objęcie bessy (Engulfing -) - & 2 & wzrostowy & trend spadkowy \\
\hline 15. & Objęcie hossy (Engulfing + ) + & 2 & spadkowy & trend wzrostowy \\
\hline 16. & Odwrócony młot (Inverted Hammer) + & 1 & spadkowy & trend wzrostowy \\
\hline 17. & Przenikanie (Piercing Line) + & 2 & spadkowy & trend wzrostowy \\
\hline 18. & Równe dno (Matching Low) + & 2 & spadkowy & trend wzrostowy \\
\hline 19. & Spadająca gwiazda (Shooting Star) - & 1 & wzrostowy & trend spadkowy \\
\hline 20. & Spotkanie (Meeting Lines) - & 2 & wzrostowy & trend spadkowy \\
\hline 21. & Spotkanie (Meeting Lines) + & 2 & spadkowy & trend wzrostowy \\
\hline 22. & $\begin{array}{l}\text { Trójka wewnętrzna spadkowa } \\
\text { (Three Inside Down) - }\end{array}$ & 3 & wzrostowy & trend spadkowy \\
\hline 23. & $\begin{array}{l}\text { Trójka wewnętrzna wzrostowa } \\
(\text { Three Inside } U p)+\end{array}$ & 3 & spadkowy & trend wzrostowy \\
\hline 24. & $\begin{array}{l}\text { Trójka zewnętrzna spadkowa } \\
\text { (Three Outside Down) - }\end{array}$ & 3 & wzrostowy & trend spadkowy \\
\hline 25. & $\begin{array}{l}\text { Trójka zewnętrzna wzrostowa } \\
(\text { Three Outside Up) }+\end{array}$ & 3 & spadkowy & trend wzrostowy \\
\hline 26. & Ucieczka (Breakaway) - & 5 & wzrostowy & trend spadkowy \\
\hline 27. & Wisielec (Hanging Man) - & 1 & wzrostowy & trend spadkowy \\
\hline 28. & $\begin{array}{l}\text { Zasłona ciemnej chmury } \\
(\text { Dark Cloud Cover })+\end{array}$ & 2 & wzrostowy & trend wzrostowy \\
\hline 29. & Zatrzymanie (Belt Hold - ) - & 1 & wzrostowy & trend spadkowy \\
\hline 30. & Zatrzymanie $($ Belt Hold +$)+$ & 1 & spadkowy & trend wzrostowy \\
\hline
\end{tabular}

(*) Ze względu na ograniczoną objętość artykułu nie przedstawiono rysunków analizowanych formacji świecowych. Rysunki wszystkich formacji wykorzystanych w niniejszym artykule można znaleźć np. w: Murphy, 1999, s. 270-277.

Źródło: opracowanie własne. 
Wszystkie formacje świecowe zostały zdefiniowane za pomocą formuł w Excelu. Formuły te są własną i oryginalną adaptacją zaleceń zawartych w monografiach Morrisa (1998) i Nisona (2008). Syntetyczny wykaz formacji zamieścił Murphy (1999), skąd zaczerpnięto polskie nazewnictwo świec. Także tam można zapoznać się z rysunkami wszystkich formacji wykorzystanych w niniejszym artykule. Większość prac dotyczących wykresów świecowych skupia się na kilku (Caginalp i Laurent, 1998; Horton, 2009; Shiu i Lu, 2011) lub kilkunastu formacjach (Marshall i in., 2006; Prado i in., 2013). W niniejszym badaniu przeanalizowano skuteczność wszystkich wymienionych przez Morrisa (1998) formacji odwrócenia trendu². Po pierwszej selekcji, w tabeli 1 przedstawiono tylko te formacje, które w badanym okresie wystąpiły przynajmniej jeden raz. Co ciekawe, formacje przewidujące zmianę trendu rozłożyły się prawie idealnie równomiernie: $53 \%$ z nich zapowiadało hossę, a $47 \%$ wskazywało na nadejście bessy. Wśród formacji 80\% stanowiły złożone z 2 lub 3 świec, $20 \%$ okazały się być najprostszymi formacjami jednoświecowymi.

Przy definicji formuł w programie Excel posłużono się wytycznymi identyfikacji świec wymienionych przez Morrisa (1998) i Nisona (2008). Najważniejszymi czynnikami było określenie wysokości korpusu świecy (różnicy pomiędzy ceną otwarcia i zamknięcia), jej dolnego i górnego cienia (różnicy pomiędzy odpowiednio najwyższą lub najniższą ceną dnia a ceną otwarcia/zamknięcia). W badaniu przyjęto założenie o wysokiej świecy, gdy jej korpus przewyższał o 30\% średnią wielkość korpusów dziesięciu poprzednich świec. Świece o długich cieniach miały korpus przynajmniej dwukrotnie wyższy od cienia, krótkie cienie świec nie mogły przekroczyć $10 \%$ wysokości korpusu. Szczególne świece typu doji ograniczono do tych, których różnica między ceną otwarcia i zamknięcia była mniejsza niż 3\% dziennego zakresu zmian ceny.

Najważniejszym elementem szukania zależności na wykresach jest zawsze identyfikacja trendu. Aby trend określić jako wzrostowy, cena zamknięcia z kolejnych trzech sesji musiała znajdować się przynajmniej dwukrotnie powyżej dziesięciodniowej ruchomej średniej wykładniczej. Dla trendu spadkowego cena zamknięcia $z$ ostatnich trzech dni musiała być niższa od kroczącej dziesięciosesyjnej średniej wykładniczej przynajmniej dwa razy. W ten sposób ominięto sytuację pojawienia się układu świec japońskich w trendzie bocznym.

2 Morris (1998) dokonał analizy 64 formacji świecowych, w tym 48 zapowiadających zmianę trendu. Pozostałe 16 dotyczyły formacji kontynuacji trendu. 


\subsection{Częstotliwość i skuteczność formacji}

W latach 2001-2016 na wykresie cenowym kontraktów futures na WIG20 pojawiła się większość typowych formacji świecowych (tab. 2). W całym okresie badawczym zaobserwowano łącznie 785 formacji, z częstotliwością na poziomie bliskim 20\%. Oznacza to, że odpowiedni układ świec pojawiał się średnio na co piątej sesji $(19,87 \%)$. Taka częstotliwość dla inwestora analizującego wykresy w okresie dziennym powinna być bardziej niż satysfakcjonująca.

$\mathrm{Z}$ danych w tabeli 2 wynika, że kierunek zmiany trendu nie ma znaczenia dla częstotliwości pojawiania się formacji świecowej, liczba wystąpień formacji zapowiadających hossę i bessę w zasadzie była wyrównana. Udział formacji świecowych prognozujących hossę wynosił 52\% ogółu zdarzeń. Najczęściej kształtowały się układy najprostsze składające się z jednej lub dwóch świec - ponad 75\%. Do najczęściej pojawiających się formacji świecowych należały: Objęcie bessy $i$ hossy, Harami (zapowiadające zmianę na zarówno trend wzrostowy, jak i spadkowy), Mtot oraz Wisielec. Pierwsze dziesięć formacji objęło ponad $75 \%$ zdarzeń. Tabele 3-5 przedstawiają skuteczność tych formacji w różnych okresach prognozy.

Ta b e l a 2. Częstotliwość występowania formacji świecowych dla FW20 w latach 2001-2016

\begin{tabular}{|c|l|c|c|}
\hline Lp. & \multicolumn{1}{|c|}{ Nazwa formacji $(*)$} & Liczba zdarzeń & Częstotliwość $(\%)$ \\
\hline 1. & Objęcie bessy (2) - & 115 & 2,91 \\
\hline 2. & Harami (2) + & 80 & 2,03 \\
\hline 3. & Harami (2) - & 71 & 1,80 \\
\hline 4. & Objęcie hossy (2) + & 63 & 1,59 \\
\hline 5. & Młot (1) + & 54 & 1,37 \\
\hline 6. & Wisielec (1) - & 54 & 1,37 \\
\hline 7. & Trójka wewnętrzna wzrostowa (3) + & 44 & 1,11 \\
\hline 8. & Gołąb (2) + & 41 & 1,04 \\
\hline 9. & Odwrócony młot (1) + & 39 & 0,99 \\
\hline 10. & Trójka wewnętrzna spadkowa (3) - & 33 & 0,84 \\
\hline 11. & Trójka zewnętrzna spadkowa (3) - & 21 & 0,78 \\
\hline 12. & Gwiazda poranna (3) + & 20 & 0,53 \\
\hline 13. & Gwiazda wieczorna (3) - & 17 & 0,51 \\
\hline 14. & Trójka zewnętrzna wzrostowa (3) + & 17 & 0,43 \\
\hline 15. & Zatrzymanie (1) + & 13 & 0,43 \\
\hline 16. & Zasłona ciemnej chmury (2) - & 0,35 \\
\hline 17. & Narada (3) - & 0,33 \\
\hline
\end{tabular}


cd. t a b. 2

\begin{tabular}{|c|l|c|c|}
\hline Lp. & \multicolumn{1}{|c|}{ Nazwa formacji (*) $^{*}$} & Liczba zdarzeń & Częstotliwość (\%) \\
\hline 18. & Przenikanie (2) + & 12 & 0,30 \\
\hline 19. & Zatrzymanie (1) - & 11 & 0,28 \\
\hline 20. & Spadająca gwiazda (1) - & 7 & 0,23 \\
\hline 21 & Równe dno (2) + & 3 & 0,18 \\
\hline 22. & Dno trzech rzek (3) + & 3 & 0,08 \\
\hline 23. & Gwiazda doji (2) + & 3 & 0,08 \\
\hline 24. & Gwiazda wieczorna doji (3) - & 3 & 0,08 \\
\hline 25. & Kanapka (3) + & 2 & 0,08 \\
\hline 26. & Dwa kruki (3) - & 1 & 0,05 \\
\hline 27. & Ucieczka (5) - & 1 & 0,05 \\
\hline 28. & Dwa kruki i luka (3) - & 1 & 0,03 \\
\hline 29. & Spotkanie (2) - & 785 & 0,03 \\
\hline 30. & Spotkanie (2) + & 2 & 0,03 \\
\hline Formacje ogółem & & 19,87 \\
\hline
\end{tabular}

(*) W nawiasie podana jest liczba świec wchodząca w skład formacji. Znaki (-) (+) przy nazwach formacji odnoszą się do zmiany trendu na spadkowy i wzrostowy po wystąpieniu formacji.

Źródło: opracowanie własne.

Skuteczność formacji świecowych została sprawdzona w trzech okresach: po trzech, pięciu i siedmiu dniach po wystąpieniu zdarzenia. Jeśli kierunek zmiany trendu był zgodny z przyjętą hipotezą dla danej formacji, zaliczało się ją do zyskownych. Formacje zakończone sukcesem to takie, dla których stopa zwrotu dla danego okresu prognozy była dodatnia ${ }^{3}$.

Osobną kwestią było przyjęcie udziału dobrych wskazań w liczbie wszystkich zdarzeń dla danej formacji, by uznać ją za wiarygodną. W praktyce większość dobrych inwestorów osiąga współczynnik udanych transakcji na poziomie 35-50\%. Źródłem ich sukcesu jest oprócz systemu transakcyjnego odpowiednie zarządzanie ryzykiem oraz wielkością pozycji w stosunku do posiadanego kapitału. W tym świetle przyjęty w badaniu poziom pięćdziesięcioprocentowej skuteczności formacji świecowych można uznać za satysfakcjonujący. Oznacza to, że skuteczna formacja to taka, która w większości przypadków pojawienia się jej generowała odpowiedni sygnał kupna/sprzedaży. Następnie stworzono ranking sukcesu dla poszczególnych okresów prognozy, według wzoru:

3 Stopa zwrotu dla okresu 3-dniowego została obliczona jako procentowa zmiana cen na zamknięciu trzeciego dnia po wystąpieniu danej formacji. Odpowiednio w ten sam sposób obliczono stopy zwrotu dla pięciu i siedmiu dni. Koszty transakcyjne zostały pominięte. W badaniu przede wszystkim skupiono się na poprawności wskazań kierunku trendu dla poszczególnych formacji. 


$$
\text { Rank }+(\text { skuteczność }-0,5)^{3} * \text { liczba }
$$

Tak przyjęta formuła obniżyła znaczenie skuteczności w stosunku do liczby wystąpień danej formacji. Im wyższy poziom Rank, tym skuteczniejszy jest dany układ świec. Wartości dodatnie oznaczają, że w większości przypadków dla danej formacji sygnał kupna/sprzedaży okazał się prawidłowy. Tabele 3-5 przedstawiają ranking formacji świecowych.

Ta b e l a 3. Skuteczność formacji świecowych dla okresu prognozy 3 dni

\begin{tabular}{|c|c|c|c|c|c|}
\hline Lp. & Nazwa formacji & Liczba & $\begin{array}{c}\text { Formacje } \\
\text { zakończone } \\
\text { sukcesem }\end{array}$ & $\begin{array}{l}\text { Skuteczność } \\
\text { po } 3 \text { dniach } \\
\text { (w \%) }\end{array}$ & Rank3 \\
\hline 1. & Trójka zewnętrzna wzrostowa (3) + & 17 & 13 & 76 & 0,2988 \\
\hline 2. & Spotkanie (2) - & 1 & 1 & 100 & 0,1250 \\
\hline 3. & Trójka wewnętrzna wzrostowa (3) + & 44 & 28 & 64 & 0,1207 \\
\hline 4. & Kanapka (3) + & 3 & 2 & 67 & 0,0147 \\
\hline 5. & Trójka wewnętrzna spadkowa (3) - & 33 & 18 & 55 & 0,0041 \\
\hline 6. & Trójka zewnętrzna spadkowa (3) - & 31 & 17 & 55 & 0,0039 \\
\hline 7. & Objęcie hossy $(2)+$ & 63 & 32 & 51 & 0,0001 \\
\hline 8. & Odwrócony młot $(1)+$ & 39 & 18 & 46 & $-0,0025$ \\
\hline 9. & Objęcie bessy (2) - & 115 & 54 & 47 & $-0,0031$ \\
\hline 10. & Młot $(1)+$ & 54 & 24 & 44 & $-0,0117$ \\
\hline 11. & Dno trzech rzek (3) + & 3 & 1 & 33 & $-0,0147$ \\
\hline 12. & Gwiazda doji (2) + & 3 & 1 & 33 & $-0,0147$ \\
\hline 13. & Gwiazda wieczorna doji (3) - & 3 & 1 & 33 & $-0,0147$ \\
\hline 14. & Harami $(2)+$ & 80 & 35 & 44 & $-0,0173$ \\
\hline 15. & Gwiazda poranna (3) + & 21 & 8 & 38 & $-0,0363$ \\
\hline 16. & Zatrzymanie $(1)+$ & 17 & 6 & 35 & $-0,0574$ \\
\hline 17. & Równe dno (2) + & 7 & 2 & 29 & $-0,0648$ \\
\hline 18. & Dwa kruki i luka (3) - & 1 & 0 & 0 & $-0,1250$ \\
\hline 19. & Spotkanie $(2)+$ & 1 & 0 & 0 & $-0,1250$ \\
\hline 20. & Zasłona ciemnej chmury (2) - & 14 & 4 & 29 & $-0,1297$ \\
\hline 21. & Zatrzymanie (1) - & 11 & 3 & 27 & $-0,1338$ \\
\hline 22. & Goląb (2) + & 41 & 14 & 34 & $-0,1679$ \\
\hline 23. & Wisielec (1) - & 54 & 19 & 35 & $-0,1823$ \\
\hline 24. & Dwa kruki (3) - & 2 & 0 & 0 & $-0,2500$ \\
\hline 25. & Ucieczka (5) - & 2 & 0 & 0 & $-0,2500$ \\
\hline 26. & Harami (2) - & 71 & 24 & 34 & $-0,2908$ \\
\hline 27. & Gwiazda wieczorna (3) - & 20 & 5 & 25 & $-0,3125$ \\
\hline 28. & Przenikanie $(2)+$ & 12 & 2 & 17 & $-0,4312$ \\
\hline 29. & Spadająca gwiazda (1) - & 9 & 1 & 11 & $-0,5339$ \\
\hline 30. & Narada (3) - & 13 & 2 & 15 & $-0,5574$ \\
\hline
\end{tabular}

Źródło: opracowanie własne. 
Do formacji skutecznych trzeciego dnia po wystąpieniu sygnału należały: Trójka zewnętrzna wzrostowa (+), Spotkanie (-), Trójka wewnętrzna wzrostowa (+), Kanapka (+), Trójka wewnętrzna spadkowa (-), Trójka zewnętrzna spadkowa (-), Objęcie hossy (+). Większość z nich (5 na 7) cechowała wysoka częstotliwość, co dobrze rokuje dla strategii wykorzystujących je w praktyce. Jak wiadomo, inwestor potrzebuje zarówno dobrych wskazań systemu transakcyjnego, jak i częstych wejść na rynek.

Ta b e l a 4. Skuteczność formacji świecowych dla okresu prognozy 5 dni

\begin{tabular}{|c|c|c|c|c|c|}
\hline Lp. & Nazwa formacji & Liczba & $\begin{array}{c}\text { Formacje } \\
\text { zakończone } \\
\text { sukcesem }\end{array}$ & $\begin{array}{c}\text { Skuteczność } \\
\text { po } 3 \text { dniach } \\
(\text { w \%) }\end{array}$ & Rank5 \\
\hline 1. & Spotkanie (2) - & 1 & 1 & 100 & 0,1250 \\
\hline 2. & Spotkanie $(2)+$ & 1 & 1 & 100 & 0,1250 \\
\hline 3. & Kanapka (3) + & 3 & 2 & 67 & 0,0147 \\
\hline 4. & Równe dno $(2)+$ & 7 & 4 & 57 & 0,0024 \\
\hline 5. & Spadająca gwiazda (1) - & 9 & 5 & 56 & 0,0019 \\
\hline 6. & Trójka wewnętrzna wzrostowa (3) + & 44 & 23 & 52 & 0,0004 \\
\hline 7. & Objęcie hossy $(2)+$ & 63 & 32 & 51 & 0,0001 \\
\hline 8. & Dwa kruki (3) - & 2 & 1 & 50 & 0,0000 \\
\hline 9. & Ucieczka (5) - & 2 & 1 & 50 & 0,0000 \\
\hline 10. & Odwrócony młot (1) + & 39 & 19 & 49 & 0,0000 \\
\hline 11. & Trójka zewnętrzna spadkowa (3) - & 31 & 15 & 48 & $-0,0002$ \\
\hline 12. & Wisielec $(1)-$ & 54 & 26 & 48 & $-0,0004$ \\
\hline 13. & Trójka zewnętrzna wzrostowa (3) + & 17 & 8 & 47 & $-0,0005$ \\
\hline 14. & Harami $(2)+$ & 80 & 37 & 46 & $-0,0051$ \\
\hline 15. & Objęcie bessy (2) - & 115 & 52 & 45 & $-0,0144$ \\
\hline 16. & Dno trzech rzek $(3)+$ & 3 & 1 & 33 & $-0,0147$ \\
\hline 17. & Zatrzymanie (1) - & 11 & 4 & 36 & $-0,0302$ \\
\hline 18. & Gwiazda poranna $(3)+$ & 21 & 8 & 38 & $-0,0363$ \\
\hline 19. & Harami (2) - & 71 & 30 & 42 & $-0,0364$ \\
\hline 20. & Zasłona ciemnej chmury (2) - & 14 & 5 & 36 & $-0,0384$ \\
\hline 21. & Młot $(1)+$ & 54 & 22 & 41 & $-0,0394$ \\
\hline 22. & Trójka wewnętrzna spadkowa (3) - & 33 & 13 & 39 & $-0,0439$ \\
\hline 23. & Gołąb $(2)+$ & 41 & 16 & 39 & $-0,0546$ \\
\hline 24. & Zatrzymanie $(1)+$ & 17 & 6 & 35 & $-0,0574$ \\
\hline 25. & Dwa kruki i luka (3) - & 1 & 0 & 0 & $-0,1250$ \\
\hline 26. & Gwiazda wieczorna (3) - & 20 & 5 & 25 & $-0,3125$ \\
\hline 27. & Gwiazda doji (2) + & 3 & 0 & 0 & $-0,3750$ \\
\hline 28. & Gwiazda wieczorna doji (3) - & 3 & 0 & 0 & $-0,3750$ \\
\hline 29. & Przenikanie $(2)+$ & 12 & 2 & 17 & $-0,4312$ \\
\hline 30. & Narada (3) - & 13 & 2 & 15 & $-0,5574$ \\
\hline
\end{tabular}

Źródło: opracowanie własne. 
Wśród skutecznych formacji świecowych dla okresu prognozy 5 dni znalazły się: Spotkanie (+,-), Kanapka (+), Równe dno (+), Spadająca gwiazda (-), Trójka wewnętrzna wzrostowa (+), Objęcie hossy (+). Do dalszej analizy przy wykorzystaniu praktycznym powyższych formacji powinna przejść jedynie Trójka wewnętrzna wzrostowa ze względu na szczególnie wysoką częstotliwość występowania.

Ta b e la 5. Skuteczność formacji świecowych dla okresu prognozy 7 dni

\begin{tabular}{|c|c|c|c|c|c|}
\hline Lp. & Nazwa formacji & Liczba & $\begin{array}{c}\text { Formacje } \\
\text { zakończone } \\
\text { sukcesem }\end{array}$ & $\begin{array}{l}\text { Skuteczność } \\
\text { po } 3 \text { dniach } \\
(w \%)\end{array}$ & Rank7 \\
\hline 1. & Dwa kruki i luka (3) - & 1 & 1 & 100 & 0,1250 \\
\hline 2. & Spotkanie $(2)+$ & 1 & 1 & 100 & 0,1250 \\
\hline 3. & Równe dno (2) + & 7 & 5 & 71 & 0,0648 \\
\hline 4. & Spadająca gwiazda (1) - & 9 & 6 & 67 & 0,0442 \\
\hline 5. & Gwiazda poranna (3) + & 21 & 13 & 62 & 0,0363 \\
\hline 6. & Dno trzech rzek (3) + & 3 & 2 & 67 & 0,0147 \\
\hline 7. & Kanapka (3) + & 3 & 2 & 67 & 0,0147 \\
\hline 8. & Objęcie hossy (2) + & 63 & 35 & 56 & 0,0136 \\
\hline 9. & Trójka zewnętrzna spadkowa (3) - & 31 & 17 & 55 & 0,0039 \\
\hline 10. & Zatrzymanie (1) - & 11 & 6 & 55 & 0,0014 \\
\hline 11. & Trójka zewnętrzna wzrostowa (3) + & 17 & 9 & 53 & 0,0005 \\
\hline 12. & Młot $(1)+$ & 54 & 28 & 52 & 0,0004 \\
\hline 13. & Objęcie bessy (2) - & 115 & 59 & 51 & 0,0001 \\
\hline 14. & Dwa kruki (3) - & 2 & 1 & 50 & 0,0000 \\
\hline 15. & Trójka wewnętrzna wzrostowa (3) + & 44 & 22 & 50 & 0,0000 \\
\hline 16. & Odwrócony młot $(1)+$ & 39 & 19 & 49 & 0,0000 \\
\hline 17. & Gołąb $(2)+$ & 41 & 19 & 46 & $-0,0026$ \\
\hline 18. & Trójka wewnętrzna spadkowa (3) - & 33 & 15 & 45 & $-0,0041$ \\
\hline 19. & Harami (2) - & 71 & 33 & 46 & $-0,0045$ \\
\hline 20. & Wisielec (1) - & 54 & 23 & 43 & $-0,0185$ \\
\hline 21. & Zasłona ciemnej chmury (2) - & 14 & 5 & 36 & $-0,0384$ \\
\hline 22. & Zatrzymanie (1) + & 17 & 6 & 35 & $-0,0574$ \\
\hline 23. & Harami $(2)+$ & 80 & 33 & 41 & $-0,0583$ \\
\hline 24. & Spotkanie (2) - & 1 & 0 & 0 & $-0,1250$ \\
\hline 25. & Przenikanie $(2)+$ & 12 & 3 & 25 & $-0,1875$ \\
\hline 26. & Ucieczka (5) - & 2 & 0 & 0 & $-0,2500$ \\
\hline 27. & Narada (3) - & 13 & 3 & 23 & $-0,2559$ \\
\hline 28. & Gwiazda wieczorna (3) - & 20 & 5 & 25 & $-0,3125$ \\
\hline 29. & Gwiazda doji $(2)+$ & 3 & 0 & 0 & $-0,3750$ \\
\hline 30. & Gwiazda wieczorna doji (3) - & 3 & 0 & 0 & $-0,3750$ \\
\hline
\end{tabular}

Źródło: opracowanie własne. 
Najbardziej obiecujące wyniki zaobserwowano w okresie 7 dni prognozy - aż 13 formacji wykazało wyższą niż pięćdziesięcioprocentową skuteczność. Są to Dwa kruki i luka (+), Spotkanie (+), Równe dno (+), Spadajaca gwiazda (-), Gwiazda poranna (+), Dno trzech rzek (+), Kanapka (+), Objęcie hossy (+), Trójka zewnętrzna spadkowa (-), Zatrzymanie (-), Trójka zewnętrzna wzrostowa (+), Mtot (+), Objęcie bessy (-). Sześć spośród nich charakteryzowała również wysoka częstotliwość występowania.

Podsumowując, najwyraźniej nie ma większego znaczenia czy formacja przewiduje hossę, czy bessę oraz z ilu świec się składa. Wśród formacji o wysokiej skuteczności znalazły się różne układy świec. Należy wyróżnić przede wszystkim te, które wskazywały dobre sygnały we wszystkich badanych okresach prognozy, czyli Spotkanie (-), Kanapka (+) oraz Objęcie hossy (+), choć jedynie ostatnia z nich ma wysoką częstotliwość. Na uwagę zasługuje również formacja Trójka wewnętrzna wzrostowa $(+)$ ze względu na częstość zdarzeń i wysoką skuteczność w okresie 3 i 5 dni po wystąpieniu sygnału. Formacja ta była udana w $50 \%$ w przypadku najdłuższego okresu -7 dni.

Zmiana trendu i formowanie się nowego kierunku zmian cen kształtuje się w dłuższym terminie niż zakładany okres 3-7 dni. Dlatego formacje poprawiające swoją skuteczność w czasie rokują dobrze, powinny zarazem podlegać dalszej obserwacji. W tej grupie formacji znalazły się: Spadajaca gwiazda (-), Objęcie hossy (+), Zatrzymanie (-), Równe dno (+), Gwiazda poranna (+). Dwie kolejne formacje, Gotą (+) oraz Harami (-), pomimo że nie osiągnęły zakładanego poziomu skuteczności po 7 dniach, to widoczna była poprawa dla obydwu układów w porównaniu z okresem 3 dni o 12 pkt proc. Dalsze poszerzenie okresu analizy być może dałoby bardziej satysfakcjonujące rezultaty, tym bardziej że dotyczyłoby formacji o wysokich częstotliwościach. Także formacje Mtota $(+)$ oraz Objęcie bessy (-) osiągnęły ponad pięćdziesięcioprocentową skuteczność $\mathrm{w}$ najdłuższym okresie prognozy i poprawiły swoją pozycję w stosunku do najkrótszego okresu 3 dni.

\section{Wnioski i dalsze badania}

Wyniki analizy skuteczności formacji świecowych dla kontraktów futures na WIG20 w latach 2001-2016 są zbieżne z otrzymanymi przez Morrisa (1998). Można zauważyć, że do sporządzenia strategii inwestycyjnej nadają się tylko niektóre formacje. Wadą większości dotychczasowych badań, np. wymienionych wcześniej autorów, była fragmentaryczna analiza bardzo ograniczonej liczby formacji. Zazwyczaj wybierali oni kilka, kilkanaście z nich i przeprowadzali standardowe badania wiarygodności. Gdyby w niniejszym badaniu skupić 
się na podobnie ograniczonej próbie, prawdopodobnie także trzeba by było odrzucić zastosowanie metodologii świec japońskich jako narzędzia inwestycyjnego. Analiza dużej liczby formacji pokazała jednak, że wiele z nich jest wartych obserwacji i powinny przejść do dalszego etapu badawczego. Podsumowując, wyniki badań zaprezentowane w niniejszym artykule są obiecujące i mogą być dobrym punktem wyjścia dla inwestora giełdowego poszukującego własnego, skutecznego, systemu inwestycyjnego.

Czy można zatem przewidzieć zmianę trendu, korzystając $\mathrm{z}$ wykresów świecowych? Niniejszy artykuł daje częściowo odpowiedź na to pytanie. Aby odpowiedzieć na nie w pełni, należy przeprowadzić jeszcze dodatkowe kroki. Kolejnym posunięciem powinna być analiza skuteczności wyselekcjonowanych formacji świecowych przy założeniu odpowiednich dla rynku kosztów transakcyjnych. Należy również zbadać wiarygodność tych formacji w okresie powyżej 7 dni, ponieważ ceny podążają zgodnie z trendem w czasie dużo dłuższym (najkrótsze trendy krótkoterminowe mają zasięg do kilku tygodni dla notowań dziennych). Przykładowo, wyjście z pozycji wygenerowanej przez formację świecową mogłoby się odbywać po zmianie trendu sygnalizowanego przez średnią kroczącą lub inny wskaźnik analizy technicznej. Do systemu transakcyjnego powinny zostać włączone tylko te formacje, które po uwzględnieniu kosztów i ewentualnych filtrów dałyby skuteczność na poziomie wyższym niż $35 \%$. Sukces inwestora zależny byłby już wtedy tylko od przyjętego ryzyka (stosunku zysku do ryzyka w każdej transakcji) oraz zarządzania wielkością pozycji (w stosunku do kapitału). W takich warunkach oczekiwana skuteczność systemu transakcyjnego powinna być dodatnia, a system powinien zapewnić sukces finansowy.

\section{Bibliografia}

Caginalp, G. i Laurent, H. (1998). The Predictive Power of price Patterns. Applied Mathematical Finance, 5, 181-205, http://dx.doi.org/10.1080/135048698334637.

Chen, S., Bao, S. i Zhou, Y. (2016). The predictive power of Japanese candlestick charting in Chinese stock market. Physica, A 457, 148-165, http://dx.doi.org/10.1016/j.physa. 2016.03.081.

Fock, J., Klein, C. i Zwergel, B. (2005). Performance of Candlestick Analysis on Intraday Futures Data. The Journal of Derivatives, 13, 28-40, http://dx.doi.org/10.3905/ jod.2005.580514.

Horton, M. (2009). Stars, crows, and doji: The use of candlesticks in stock selection. The Quarterly Review of Economics and Finance, 49, 283-394, http://dx.doi.org/10.1016/ j.qref.2007.10.005.

Lempart, J. i Zalewski, G. (2013). Leksykon formacji świecowych. Warszawa: Wydawnictwo Linia. 
Marshall, B., Young, M. i Rose, L. (2006). Candlestick technical trading strategies: Can they create value for investors? Journal of Banking and Finance, 30, 2303-2323, http:// dx.doi.org/10.1016/j.jbankfin.2005.08.001.

Morris, G. (1998). Wykresy świecowe. Warszawa: Dom Wydawniczy ABC.

Murphy, J. (1999). Analiza techniczna rynków finansowych. Warszawa: Wydawnictwo WIGPRESS.

Nison, S. (2008). Świece i inne japońskie techniki analizowania wykresów. Warszawa: Wydawnictwo WIG-PRESS.

Prado, H., Ferneda, E., Morais, L., Luiz, A. i Matsura, E. (2013). On the effectiveness of candlestick chart analysis for the Brazilian stock market. Procedia Computer Science, 22, 1136-1145, http://dx.doi.org/10.1016/j.procs.2013.09.200.

Shiu, Y-M. i Lu T-H. (2011). Prinpoint and Synergistic Trading Strategies of Candlestick. International Journal of Economics and Finance, 3, 234-244.

Smith, D., Faugere, Ch. i Wang, Y. (2013). Head and Shoulders above the Rest? The Performance of Institutional Portfolio Managers who Use Technical Analysis. Department of Finance and Center for Institutional Investment Management, http://dx.doi.org/10.2139/ ssrn.2202060. 



\title{
Rozdział VII
}

\author{
TOMASZ PROKOPOWICZ*, TADEUSZ KRUPA**
}

\section{Koncepcja zastosowania teorii charakteryzacji Gorbatova do budowy modelu wspomagającego analizę portfela akcji spółek giełdowych}

Inwestorzy rynku kapitałowego codziennie podejmują decyzje, odnośnie do najbardziej optymalnej alokacji swojego kapitału (dającej najwyższy zwrot) w walory spółek notowanych na giełdzie. Każdej z tych decyzji towarzyszy ryzyko związane z niekorzystną (dla inwestora) zmianą kursu cen akcji. Aby je ograniczyć, stosuje się wiele metod wspomagających analizę swojego portfela inwestycyjnego. W niniejszym artykule przedstawiono koncepcję zastosowania teorii charakteryzacji Gorbatova do budowy modelu, który mógłby stanowić narzędzie wspierające ocenę portfela akcji notowanych na Warszawskiej Giełdzie Papierów Wartościowych. Koncepcja ta jest pierwszą próbą zastosowania wyżej wymienionej teorii w zagadnieniach związanych z modelowaniem zjawisk na rynku kapitałowym.

Słowa kluczowe: teoria charakteryzacji Gorbatova, analiza fundamentalna, analiza ekonomiczno-finansowa przedsiębiorstwa.

\section{Concept of Applying Gorbatov Theory of Characterization to Building A Model Supporting Analysis of Portfolio Shares of Listed Companies}

Everyday investors of Capital Market making decisions of the most optimal allocation of their capital (giving the highest return) in shares of companies listed on the stock exchange. Each of

mgr inż. Tomasz Prokopowicz - Wydział Zarządzania, Politechnika Warszawska, ul. Narbutta 85, 02-524 Warszawa; e-mail: tp.prokopowicz@gmail.com.

** prof. dr hab. inż. Tadeusz Krupa - Wydział Zarządzania, Politechnika Warszawska, ul. Narbutta 85, 02-524 Warszawa; e-mail: t.krupa@wz.pw.edu.pl. 
those decisions involves the risk associated with unfavorable (for the investor) a change of the prices of shares. To reduce the risk, they use a number of methods supporting the analysis of investment portfolio. The article presents the concept of the application of the Corbatov theory of characterization to build a model that could serve as a tool to support the assessment of the portfolio of listed shares. This concept is the first attempt to apply the aforementioned theory on issues related to the modeling of phenomena on the capital market.

Keywords: gorbatov theory of characterization, fundamental analysis, economic and financial company analysis.

JEL: G11, G14

\section{Wprowadzenie}

Działalność gospodarcza przedsiębiorstw, a w szczególności spółek notowanych na giełdzie, powinna opierać się na podejmowaniu decyzji, które z jednej strony będą adaptować organizację do ciągle zmieniających się warunków otoczenia, a z drugiej, co ważniejsze, „wyprzedzać” dominujące w danej branży trendy. Osiąganie ponadprzeciętnych rezultatów jest możliwe wtedy, gdy firma ma do zaoferowania odpowiednio tańszą, jakościową lepszą i (lub) zdecydowanie bardziej innowacyjną ofertę niż jej konkurenci. W przeciwnym wypadku będzie skazana na „przeciętność” lub co gorsza, trudności finansowe wynikające $\mathrm{z}$ relatywnie mniejszego, niż u pozostałych, zainteresowania jej produktami lub usługami. Biorąc to pod uwagę, inwestorzy rynku kapitałowego (banki, firmy ubezpieczeniowe, fundusze inwestycyjne, domy maklerskie etc.) muszą rozwiązać stojące przed nimi problemy:

- w jaki sposób ocenić czy mamy do czynienia z „przeciętnym”, czy „ponadprzeciętnym" podmiotem i jaki ma to związek z jego aktualną kondycją finansową oraz zmianą kursu akcji?

- w które spółki warto inwestować, ze względu na silne fundamenty prowadzonej działalności, a z których spółek należy „wycofać kapitał”, istnieje bowiem ryzyko pojawienia się trudności finansowych i (lub) spadku kursu akcji?

Do oceny spółek (konstrukcji portfela akcji) może posłużyć analiza fundamentalna, która jest jedną z metod wspomagających decyzje inwestorskie na rynku kapitałowym. Opiera się ona na połączeniu wielu źródeł informacji w jedną, spójną ocenę przedsiębiorstwa. W ramach analizy fundamentalnej agregowane są dane pochodzące $\mathrm{z}$ : 
- przedsiębiorstwa - m.in. prospekt emisyjny, raporty finansowe (bieżące, okresowe), prognozy wyników finansowych, wypowiedzi, deklaracje i oświadczenia przedstawicieli spółki;

- branży - m.in. dane statystyczne oraz informacje pochodzące z sektora, w ramach którego działa spółka, pozycja spółki w branży, konkurencja, potencjał branży;

- gospodarki - m.in. dane o charakterze makroekonomicznym, aktualna polityka gospodarcza, monetarna.

Przy czym, inwestorzy zwracają bardzo dużą uwagę na ocenę stanu ekonomiczno-finansowego podmiotu(-ów), zwłaszcza w kontekście jego konkurencji (w ramach branży) czy w porównaniu z innymi sektorami gospodarczymi.

W niniejszym opracowaniu przedstawiono koncepcję zastosowania teorii charakteryzacji Gorbatova do budowy modelu wspomagającego analize portfela akcji opartą na ocenie kondycji finansowej przedsiębiorstw. Model ten mógłby stanowić narzędzie dla wspomagania decyzji inwestorów (np. w ramach analizy fundamentalnej, doboru spółek do portfela akcji) oraz kadry zarządzającej spółek notowanych na giełdzie. Koncepcja zastosowania teorii charakteryzacji do budowy modelu oceny stanu ekonomiczno-finansowego przedsiębiorstw została zweryfikowana $\mathrm{w}$ ramach przeprowadzonych przez autorów badań nad problematyką upadłości polskich firm (Prokopowicz i Krupa, 2010, s. 71-97). Zdaniem autorów, istnieje możliwość opracowania takiego modelu na potrzeby analizy spółek notowanych na Giełdzie Papierów Wartościowych w Warszawie.

\section{Wpływ kondycji ekonomiczno-finansowej przedsiębiorstw na decyzje dotyczące posiadanego portfela akcji}

\subsection{Czynniki wpływające na kurs akcji przedsiębiorstw}

Ceny akcji na rynku kapitałowym (podobnie jak na każdym innym) ustalane są w ramach „gry sił” popytu i podaży, w tym wypadku, na dany walor przedsiębiorstwa.

Na przebieg tej „gry” będą miały wpływ czynniki makro- i mikroekonomiczne oraz te, które są np. związane preferencjami inwestorów dotyczącymi poziomu zaangażowania finansowego w dany rynek kapitałowy, przepływem kapitału w globalnej gospodarce czy też alternatywnymi możliwościami inwestycyjnymi (Nowak i Ryć, 2008, s. 9-29). Proces decyzyjny inwestorów dotyczący zakupu lub sprzedaży akcji danej firmy będzie się opierał na (mniej lub 
bardziej dokładnym) określeniu siły wpływu tychże zmiennych na kurs walorów przedsiębiorstw tworzących portfel. O ile można jeszcze określić kierunek zmiany kursu akcji (spadek, wzrost), o tyle bardzo trudno jest przewidzieć skalę tej zmiany, a ta niejednokrotnie będzie decydowała o tym czy i jaki będzie zwrot (strata) z zainwestowanego kapitału.

Ry s u n e 1. Czynniki wpływające na decyzje inwestorów na rynku kapitałowym

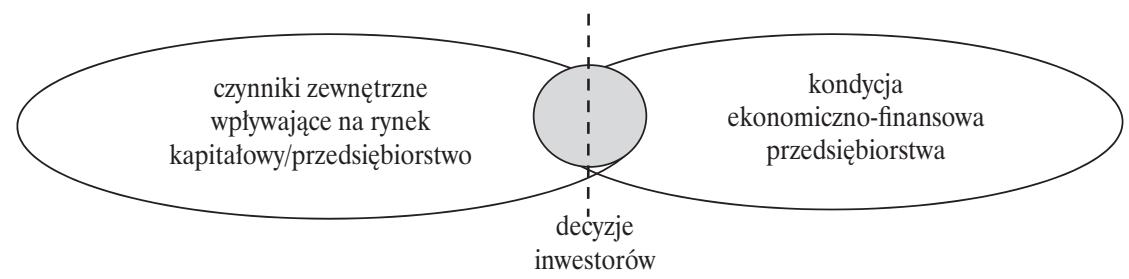

Źródło: opracowanie własne.

Szczególne miejsce w ocenie zmiennych kształtujących cenę kursu akcji zajmuje analiza stanu ekonomiczno-finansowego danego podmiotu. Inwestorzy rynku kapitałowego mają świadomość, że im lepsza kondycja ekonomicznofinansowa firmy, tym większe szanse, że przedsiębiorstwo poradzi sobie w niesprzyjających warunkach makro- czy też mikroekonomicznych (Zaleska, 2012). Co więcej - sprzyjające otoczenie gospodarcze firmy o dobrej kondycji pozwala jej na zdecydowanie lepsze wykorzystanie pojawiających się szans.

Można przyjąć założenie, iż w ramach istniejących preferencji inwestora jego decyzje na rynku kapitałowymi będą zależały od:

- oceny charakteru wpływu (pozytywny, negatywny) zmiennych zewnętrznych (makro- i mikroekonomiczne, przepływ kapitału na rynkach globalnych, alternatywne możliwości inwestycyjne) na kurs akcji spółek giełdowych (w szczególności przedsiębiorstwo);

- oceny kondycji finansowej przedsiębiorstw (lepsza, gorsza w porównaniu $\mathrm{z}$ innymi podmiotami).

Scenariusze działań na rynku kapitałowym można zawrzeć w trzech alternatywach: inwestuj (oczekiwany jest wzrost kursu akcji), sprzedawaj (oczekiwany jest spadek kursu akcji), rozważ/wstrzymaj się (potrzebne są dodatkowe informacje do podjęcia ostatecznej decyzji o inwestowaniu lub sprzedawaniu walorów danej spółki). 


\subsection{Scenariusze inwestycyjne w zależności od czynników wpływających na kurs akcji przedsiębiorstw}

W danym momencie, w zależności od tego jak inwestorzy będą oceniać charakter wpływu czynników zewnętrznych na giełdę oraz przedsiębiorstwo (pozytywny, negatywny), oraz jaka będzie ocena stanu ekonomiczno-finansowego podmiotu (lepsza niż u innych, gorsza niż u innych), przy akceptowanym przez decydenta poziomie ryzyka, możliwe są poniższe (prawdopodobne) scenariusze postępowania (tab. 1).

Ta b e la 1. Scenariusze decyzji inwestycyjnych w zależności od czynników wpływających na kurs akcji

\begin{tabular}{|c|c|c|}
\hline \begin{tabular}{|rr} 
& Wpływ zmiennych zewnętrznych \\
na rynek kapitalowy
\end{tabular} & Pozytywny & Negatywny \\
\hline Lepsza niż u innych podmiotów & inwestuj & rozważ \\
\hline Gorsza niż u innych podmiotów & rozważ & sprzedawaj \\
\hline
\end{tabular}

Źródło: opracowanie własne.

Wybrany scenariusz będzie realizowany, gdy zajdą następujące okoliczności:

1. Inwestuj - jeśli charakter wpływu zmiennych na rynek kapitałowy jest pozytywny (np. notowany jest wzrost PKB) i kondycja danego przedsiębiorstwa jest lepsza niż u innych, ocenianych (porównywanych jako alternatywa) podmiotów, to jest wielce prawdopodobne, że akcje takiego przedsiębiorstwa wzrosną (ze względu na swoją kondycję finansową ma możliwość wykorzystania szans rynkowych w znacznie większym stopniu niż podmiot o gorszej kondycji).

2. Rozważ - inwestor musi podjąć decyzję (inwestuj/sprzedawaj) na podstawie dodatkowych zmiennych, gdyż nie do końca można określić w jakim kierunku zmieni się kurs akcji:

a) kondycja finansowa przedsiębiorstwa jest gorsza niż u innych, ocenianych (porównywanych jako alternatywa) podmiotów, ale z racji tego, że zmienne zewnętrzne wpływają pozytywnie na rynek kapitałowy, to dane przedsiębiorstwo wykorzysta (lub nie) pojawiające się szanse rynkowe. Jeśli wykorzysta, to może nastąpić wzrost kursu akcji (poprawia się jej kondycja finansowa) - w przeciwnym wypadku, zainteresowanie taką spółką może spaść (zwiększy się podaż akcji na rynku), a tym samym dojdzie do spadku kursu walorów; 
b) kondycja finansowa przedsiębiorstwa jest lepsza niż u innych, ocenianych (porównywanych jako alternatywa) podmiotów, ale z racji tego, że zmienne zewnętrzne wpływają negatywnie na rynek kapitałowy, to dane przedsiębiorstwo może mieć trudność w realizacji założonych celów. W tej sytuacji jest prawdopodobne, że inwestorzy będą chcieli pozbyć się walorów tejże spółki, a tym samym cena akcji może spaść. Jeśli jednak okaże się, że czynniki zewnętrzne nie wpłyną negatywnie na realizację założonych celów (np. wzrost sprzedaży), to można oczekiwać wzrostu notowań akcji tego podmiotu.

3. Sprzedawaj - jeśli charakter wpływu zmiennych na rynek kapitałowy jest negatywny i kondycja danego przedsiębiorstwa jest gorsza niż u innych, ocenianych (porównywanych jako alternatywa) podmiotów, to jest wielce prawdopodobne, że akcje takiego przedsiębiorstwa spadną (ze względu na swoją kondycję finansową i pogarszającą się sytuację np. mikro-, makroekonomiczność firma może mieć duże trudności w osiągnięciu założonych celów).

Inwestor maksymalizujący zwrot $\mathrm{z}$ zainwestowanego kapitału w dany portfel akcji (przy akceptowanym dla niego ryzyku) będzie z jednej strony powiększał liczbę spółek, dla których możliwy scenariusz określony został jako inwestuj (oczekuje się wzrostu kursu akcji), a z drugiej minimalizował liczbę tych podmiotów, których walory należy sprzedawać (oczekuje się spadku kursu akcji). Trzeba jednak zaznaczyć, że oprócz tak jednoznacznych (ekonomicznych) kryteriów decyzyjnych, coraz częściej mówi się o konstruowaniu portfela w oparciu o tzw. koncepcję społecznie odpowiedzialnego inwestowania, tj. takiego, które przy wyborze spółek dodatkowo uwzględnia takie aspekty, jak wpływ przedsiębiorstwa na środowisko czy też szeroko rozumiane społeczeństwo (Czerwińska, 2012, s. 129-140).

\subsection{Portfel akcji jako forma zapisu stanu ekonomiczno-finansowego przedsiębiorstw}

Inwestorzy lokują kapitał w spółki o różnej kondycji finansowej. W danym czasie portfel akcji można rozpatrywać jako zbiór przedsiębiorstw o określonym stanie ekonomiczno-finansowym. Zmiany stanu ekonomiczno-finansowego przedsiębiorstw w czasie to de facto zmiany „zapisu informacji” o ich kondycji w posiadanym przez inwestora portfelu akcji (rys. 2).

O ile kursy akcji mogą podlegać codziennym wahaniom, o tyle wywołanie trwałej zmiany w stanie ekonomiczno-finansowym przedsiębiorstwa wymaga czasu (np. ze względu na efekt opóźnień, jaki powstaje między wdrożonymi na poziomie przedsiębiorstwa działaniami a ich rezultatem). 
Rys u n e 2. Zmiana stanu ekonomiczno-finansowego w portfelu
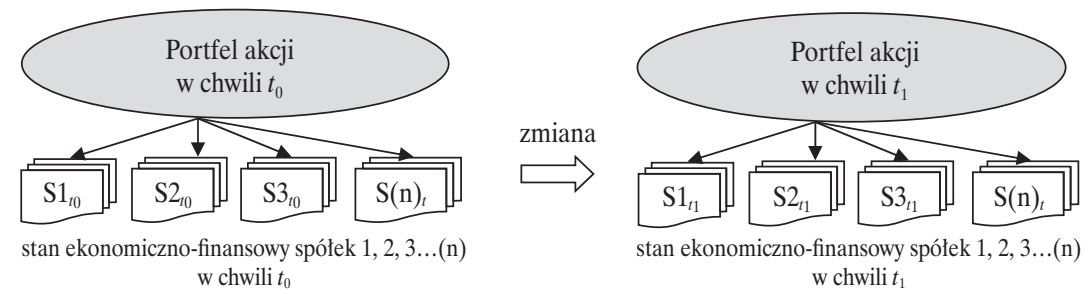

Źródło: opracowanie własne.

Kondycja ekonomiczno-finansowa będzie w dużej mierze zależała od tego, w jakim stopniu firma adaptuje się do zmian warunków otoczenia (globalnego, makroekonomicznego, branżowego - działania o charakterze strategicznym) oraz eliminuje ograniczenia na poziomie zasobów, struktur, procesów, które hamują możliwy do osiągnięcia rozwój przedsiębiorstwa (działania o charakterze operacyjnym). Pojawiająca się w procesie decyzyjnym pętla sprzężenia zwrotnego powoduje, że im bardziej adekwatna jest odpowiedź firmy na pojawiające się w jej otoczeniu zmiany, tym większe są szanse na osiągnięcie satysfakcjonujących rezultatów finansowych, które z kolei będą zachęcały do kontynuowania obranej strategii. Odwrotnie - nieadekwatna lub brak reakcji na zmiany skutkuje gorszymi rezultatami finansowymi, które w konsekwencji mogą doprowadzić do konieczności wdrożenia strategii zapobiegającej upadłości przedsiębiorstwa.

\section{Zastosowanie teorii charakteryzacji Gorbatova w procesie modelowania zjawisk ekonomicznych}

\subsection{Przestrzeń problemowa w ocenie kondycji finansowej spółek giełdowych}

Z punktu widzenia analizy fundamentalnej i modelowania zjawisk na rynku kapitałowym uzasadnione jest postawienie następujących pytań (rys. 3):

1) czy na podstawie analizy ekonomiczno-finansowej (kondycji finansowej) przedsiębiorstw, które w danym czasie notują wzrost (spadek) wartości akcji można określić „wzorce poprawnego (błędnego) działania” i jeśli tak, to w jaki sposób je identyfikować, a następnie wykorzystać w procesie podejmowania decyzji inwestycyjnych;

2) jeśli analiza ekonomiczno-finansowa dostarczyłaby informacji o występujących „wzorcach poprawnego (błędnego) działania” przedsiębiorstw to czy można je zapisać w postać modelu, a jeśli tak, to za pomocą jakiej metody; 
3) czy można byłoby opracować taki model „wzorców”, który byłby wskazówką dla inwestorów do oceny potencjału (wartości) posiadanego portfela akcji? Czy otrzymane za pomocą tego modelu informacje mogłyby posłużyć kadrze zarządzającej jako punkt odniesienia do analizy własnego przedsiębiorstwa?

Na podstawie powyższych pytań można sformułować następujący problem badawczy. Poszukiwany jest model, który na podstawie sprawozdań finansowych przedsiębiorstw notowanych na Giełdzie Papierów Wartościowych w Warszawie:

1) pozwoliłby określić cechy charakterystyczne zmian w stanie ekonomicznofinansowym 3 grup przedsiębiorstw:

a) grupy, której ceny akcji w danym okresie i w danej branży wzrosły;

b) grupy, której ceny akcji w danym okresie i w danej branży spadły;

c) grupy, która wchodzi w skład dowolnego portfela inwestycyjnego;

2) na podstawie cech charakterystycznych pozwoliłby wyznaczyć (z punktu widzenia stanu ekonomiczno-finansowego, w danym okresie, w danej branży) „wzorcowe strategie” grupy przedsiębiorstw, których ceny akcji wzrosły oraz grupy, której ceny akcji spadły;

3) umożliwiłby ocenę dowolnego portfela akcji (w danym okresie, w danej branży) pod względem zbieżności strategii realizowanej przez przedsiębiorstwa wchodzące w skład portfela inwestycyjnego ze „strategią wzorcową”.

Ry s u e k 3. Problem oceny portfela akcji w procesie inwestycyjnym

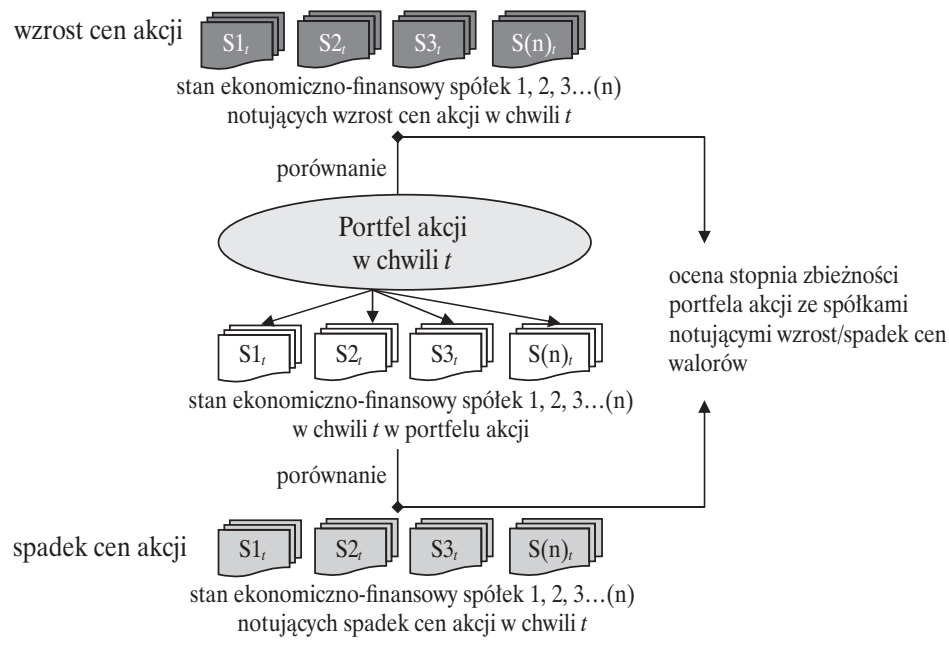

Źródło: opracowanie własne. 


\subsection{Podstawy metodyczne teorii charakteryzacji Gorbatova}

W latach 70. ubiegłego wieku, w ramach dynamicznie rozwijającej się dziedziny nauk, jaką jest teoria systemów, wybitny cybernetyk V.A. Gorbatov sformułował podstawy teorii charakteryzacji (Krupa, 2013, s. 89-102). Kierując się jej głównymi postulatami, ,[...]:

1) poszukiwać należy nie samych rozwiązań, ale tylko ich cech charakterystycznych;

2) cechy rozwiązań należy odnosić do tworzonych przedstawicieli klas (reprezentantów, inwariantów) równoważnych rozwiązań;

3) klasa równoważnych rozwiązań powstaje w wyniku interpretacji danych wejściowych rozwiązywanej grupy zadań z obszaru problemowego w kategoriach cech rozwiązań jej przedstawiciela” (Nazaretow, Kim i Krupa, 1991, s. 140),

możemy znaleźć rozwiązanie złożonych, wielowymiarowych problemów bez konieczności generowania całego, możliwego zbioru ich potencjalnych rozwiązań. Wynika to z tego, że „klas równoważnych rozwiązań jest zwykle mniej niż samych rozwiązań" (Nazaretow, Kim i Krupa, 1991, s. 141). W świetle teorii charakteryzacji, rozwiązanie problemu będzie możliwe, gdy znajdziemy (opracujemy) model funkcjonowania pewnego obiektu, który będzie wzajemnie interpretowalny z modelem jego struktury (jest to podstawowa idea teorii charakteryzacji). „Wzajemna interpretowalność modeli jest uzyskiwana przez:

- dobór uniwersalnych praw „poprawnego” funkcjonowania (wyrażonych w modelu funkcjonowania),

- strukturalną (techniczną) interpretację modelu funkcjonowania (...)" (Nazaretow, Kim i Krupa, 1991, s. 141).

„Uniwersalne prawa poprawnego funkcjonowania są wyrażone za pomocą tzw. figur grafowych, określanych jako:

- obowiązkowe - konstrukcje abstrakcyjne, które w postaci homeomorfizmów powinny wystąpić w modelu funkcjonowania „pod groźbą” jego niepoprawności;

- zabronione - łatwo identyfikowalne obiekty, których odizolowanie lub rozszczepienie (w modelu funkcjonowania) daje gwarancje uzyskania poprawności funkcjonowania obiektu;

- neutralne - służą do dokonywania przekształceń upraszczających model funkcjonowania, w wyniku których nie dochodzi do powstania figur zabronionych i figur obowiązkowych" (Prokopowicz i Krupa, 2010, s. 75). 
Według teorii charakteryzacji „obiekt (zasób) będzie funkcjonował poprawnie jeżeli uda się określić i udowodnić wzajemnie jednoznaczną interpretację między regułami jego funkcjonowania (opisanymi za pomocą modelu funkcjonowania $\psi_{a}$ ) a strukturą, która to realizuje (opisaną za pomocą modelu struktury $\left.\psi_{b}\right)$ ) (Nazaretow, Kim i Krupa, 1991, s. 141).

Aby określić i udowodnić jednoznaczną interpretację tych dwóch modeli, przyjmuje się następujące założenia:

- zasób funkcjonuje adekwatnie do jego struktury,

- struktura zasobu jest adekwatna do jego pożądanego sposobu funkcjonowania.

„Podstawowy model teorii charakteryzacji jest zapisywany jako:

$$
<\psi_{a}, \psi_{b}, P_{0}\left(\psi_{a}, \psi_{b}\right)>
$$

gdzie:

$\psi_{a}$ - model funkcjonowania,

$\psi_{b}$ - model struktury,

$P_{0}\left(\psi_{a}, \psi_{b}\right)$ - predykat atomiczny charakteryzujący możliwość interpretacji modelu funkcjonowania $\psi_{a}$ w kategoriach modelu struktury $\psi_{b}$ " (Nazaretow, Kim i Krupa, 1991, s. 142).

Zastosowanie zasady charakteryzacji w praktyce sprowadza się do opracowania adekwatnej dla badanego zjawiska teorii, która będzie wyrażona za pomocą modeli $\psi_{a}, \psi_{b}$ oraz predykatu $P_{0}$ (Nazaretow, Kim i Krupa, 1991, s. 142).

\subsection{Metodyka zastosowania teorii charakteryzacji do budowy modelu wspomagającego ocenę portfela akcji}

Poszukiwanie rozwiązania sformułowanego problemu badawczego w oparciu o teorię charakteryzacji jest realizowane w ramach następujących po sobie etapów (rys. 4):

1) dla sformułowanego problemu badawczego tworzone są:

a) system reprezentacji (sposób opisu) wyrażony za pomocą logicznej funkcji zdaniowej opracowanej z wykorzystaniem języka rachunku predykatów i rachunku zdań;

b) definicje uniwersalnych praw poprawnego funkcjonowania w postaci figur grafowych (zabronionych, obowiązkowych, neutralnych); 
2) dla opracowanej logicznej funkcji zdaniowej tworzona jest jej reprezentacja w formie grafowego modelu zdania logicznego; w modelu tym zawierają się grafowe figury zabronione;

3) usunięcie figur zabronionych z grafowego modelu zdania logicznego prowadzi do opracowania grafowego modelu funkcjonowania $\psi_{a}$;

4) w oparciu o zdefiniowanych predykat atomiczny $P_{0}\left(\psi_{a}, \psi_{b}\right)$ poszukiwana jest strukturalna interpretacja modelu funkcjonowania $\psi_{a} \mathrm{w}$ postaci grafowego modelu struktury $\psi_{b}$; model ten jest ostatecznym rozwiązaniem danego problemu.

\section{Ry s u n e k 4. Etapy rozwiązania problemu badawczego w świetle teorii charakteryzacji}

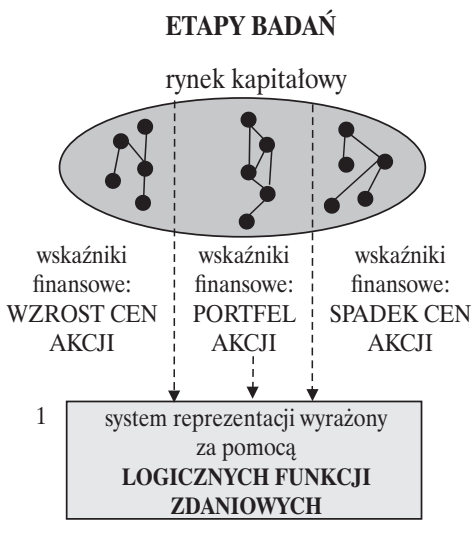

REZULTAT BADAŃ

2
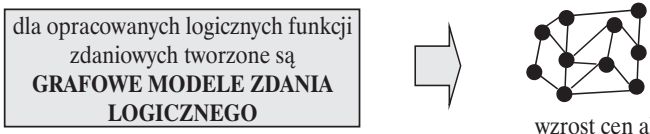

$Z W_{t}\left(R_{1},-R_{1}, R_{2},-R_{2}, R_{3},-R_{3}, \ldots, R_{30},-R_{30}\right)=$

$=-R_{1} \wedge-R_{2} \wedge-R_{3}, \ldots, \wedge R_{30} \vee R_{1} \wedge-R_{2} \wedge R_{3}, \ldots, \wedge-R_{30} \vee$

$\vee R_{1} \wedge-R_{2} \wedge-R_{3}, \ldots, \wedge R_{30} \vee-R_{1} \wedge R_{2} \wedge R_{3}, \ldots, \wedge-R_{30}$

portfel akcji

$Z P_{t}\left(R_{1},-R_{1}, R_{2},-R_{2}, R_{3},-R_{3}, \ldots, R_{30},-R_{30}\right)=$

$=R_{1} \wedge-R_{2} \wedge-R_{3}, \ldots, \wedge R_{30} \vee-R_{1} \wedge R_{2} \wedge-R_{3}, \ldots, \wedge R_{30} \vee$

$\vee R_{1} \wedge R_{2} \wedge R_{3}, \ldots, \wedge R_{30} \vee-R_{1} \wedge R_{2} \wedge R_{3}, \ldots, \wedge-R_{30}$

spadek cen akcji

$Z S_{t}\left(R_{1},-R_{1}, R_{2},-R_{2}, R_{3},-R_{3}, \ldots, R_{30},-R_{30}\right)=$

$=R_{1} \wedge R_{2} \wedge-R_{3}, \ldots, \wedge-R_{30} \vee-R_{1} \wedge R_{2} \wedge-R_{3}, \ldots, \wedge R_{30} \vee$

$\vee R_{1} \wedge R_{2} \wedge R_{3}, \ldots, \wedge R_{30} \vee-R_{1} \wedge R_{2} \wedge R_{3}, \ldots, \wedge-R_{30}$
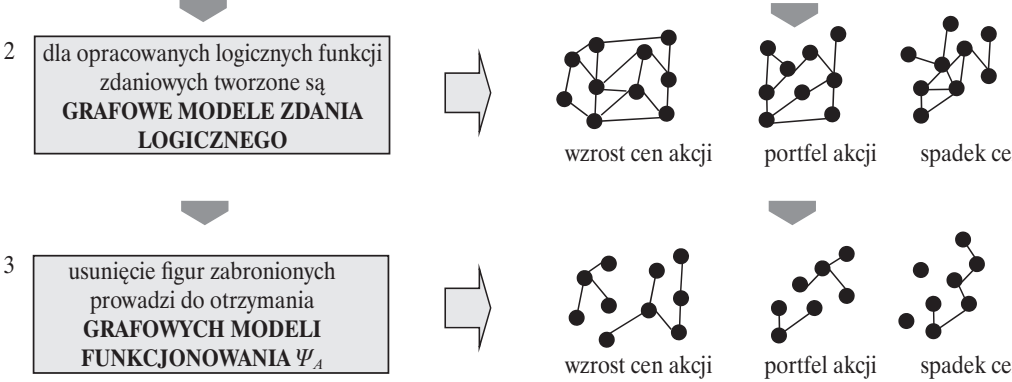

wzrost cen akcji

portfel akcji

spadek cen akcji

4 zastosowanie predykatu atomicznego prowadzi do otrzymania GRAFOWYCH MODELI STRUKTURY $\Psi_{B}$
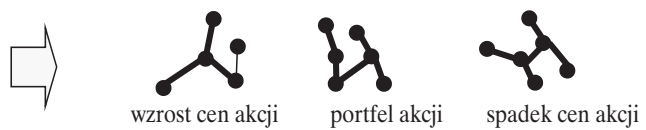

Źródło: opracowanie własne. 
Zdaniem autorów istnieje możliwość opracowania takiego modelu(-i), który bazując na wskaźnikach ekonomiczno-finansowych opisujących kondycję finansową spółek giełdowych, pozwoliłby ocenić w jakim stopniu dowolny portfel akcji jest „zbieżny” ze stanem ekonomicznym firm, które notują wzrost lub spadek cen akcji na giełdzie ( $w$ danym, analizowanym momencie - na podstawie grafowego modelu struktury). W zależności od tego czy stopień zbieżności jest wyższy w grupie firm notujących wzrost cen akcji, czy też w grupie firm notujących spadek akcji będzie można oczekiwać wzrostu lub spadku wartości posiadanego portfela.

Autorzy niniejszej publikacji przeprowadzili eksperymenty badawcze nad zastosowaniem teorii charakteryzacji w modelowaniu zjawiska upadłości polskich przedsiębiorstw (Prokopowicz i Krupa, 2010, s. 71-97). Bazując na próbie 52 polskich przedsiębiorstw udało się opracować modele funkcjonowania oraz wzajemnie interpretowalne z nimi modele struktury dwóch grup przedsiębiorstw - przetrwałych (26 podmiotów funkcjonujących w latach 2000-2004) oraz upadłych (26 podmiotów, które ogłosiły bankructwo w latach 2000-2004). $\mathrm{Na}$ podstawie interpretacji tychże modeli, udało się zidentyfikować wspólne cechy (z punktu widzenia stanu ekonomiczno-finansowego) każdej z grup przedsiębiorstw. Uzyskane rezultaty pozwoliły zidentyfikować „strategię upadłości”, tj. najbardziej „uczęszczaną” drogę w grafowym modelu struktury firm, które upadły. Co więcej, na jej podstawie można było określić stopień zagrożenia bankructwem dowolnego przedsiębiorstwa (niepochodzącego z próby badawczej). „Strategia upadłości” mogła stanowić punkt odniesienia dla innych firm - w tym przypadku ostrzegający przed możliwym niebezpieczeństwem zakończenia działalności w ciągu 3 najbliższych lat.

Rysunek 5 przedstawia koncepcje oceny portfela akcji z wykorzystaniem modeli opracowanych z wykorzystaniem teorii charakteryzacji. Strategie wzorcowe poszczególnych grup firm (wzrost cen akcji, spadek cen akcji) stanowią punkt odniesienia dla portfela inwestycyjnego. Na podstawie stopnia dopasowania grafowych modeli struktury (portfel vs. wzrost cen akcji, portfel vs. spadek cen akcji) można określić „szansę” na uzyskanie zwrotu lub poniesienia straty na akcjach spółek tworzących dany portfel. 


\section{Ry s u n e k. Koncepcja oceny portfela inwestycyjnego w świetle modeli opracowanych z zastosowaniem teorii charakteryzacji}

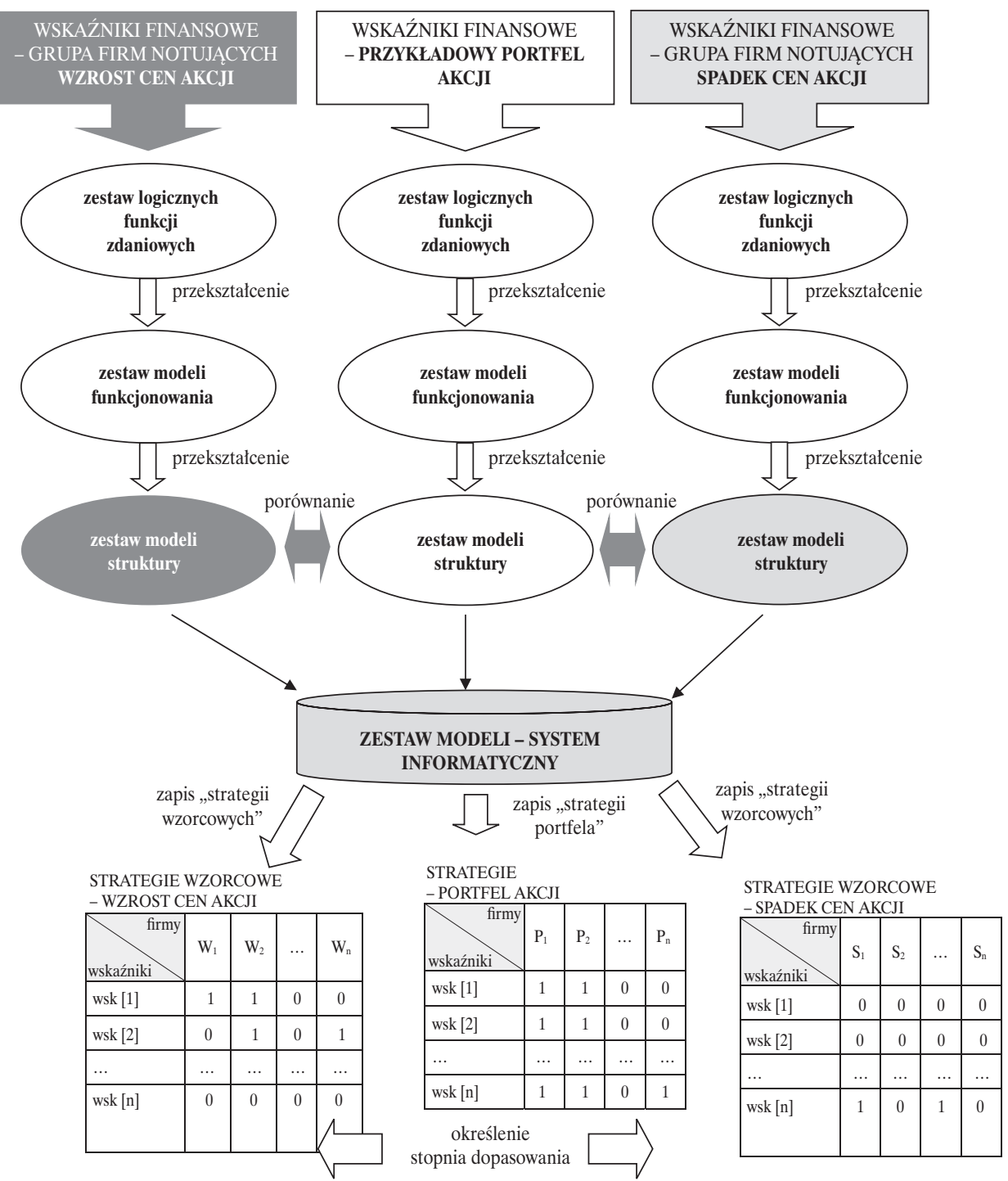

Źródło: opracowanie własne. 


\section{Podsumowanie}

Przedstawione wyżej rozważania pozwalają autorom założyć, że możliwe jest zastosowanie teorii charakteryzacji do budowy, opisanego w formie koncepcji, modelu (rozwiązania) wspomagającego decyzje inwestorów na Warszawskiej Giełdzie Papierów Wartościowych. Przeprowadzenie eksperymentów badawczych w tym zakresie mogłoby doprowadzić do celu, jakim jest opracowanie praktycznego narzędzia, które w ramach analizy fundamentalnej umożliwiałoby ocenę różnych portfeli akcji w kontekście szans na osiągnięcie potencjalnych zysków (lub poniesienia ewentualnych strat). Główną zaletą teorii charakteryzacji jest to, że poprzez fakt, iż łączy ona w sobie elementy rachunku predykatów i zdań oraz teorii grafów, może być zastosowana do rozwiązania złożonych i wielowymiarowych problemów bez konieczności przeszukiwania całego zbioru możliwych rozwiązań. Jej praktyczna weryfikacja, w zakresie modelowania zjawisk ekonomicznych, została potwierdzona w ramach przeprowadzonych przez autorów badań nad zjawiskiem upadłości polskich przedsiębiorstw.

\section{Bibliografia}

Czerwińska, T. (2012). Efektywność inwestycji społecznie odpowiedzialnych na rynku akcji. Problemy Zarzadzania, 10(4/39), t. 1.

Krupa, T. (2013). V.A. Gorbatov Theory of Characterization - Principles and Examples. Foundations of Management, 5(3).

Nazaretow, W.M., Kim, D.P. i Krupa, T. (1991). Techniczna imitacja intelektu. Warszawa: WNT.

Nowak, A.Z. i Ryć, K. (2008). Tendencje na rynkach finansowych a polski złoty - ujęcie jakościowe. Studia Europejskie/Centrum Europejskie Uniwersytetu Warszawskiego, 2.

Prokopowicz, T. i Krupa, T. (2010). Modeling of Polish Enterprises Insolvency Processes with Use of Gorbatov Charakterization Principle - Research Results. Foundations of Management, 2(1).

Zaleska, M. (2012). Ocena ekonomiczno-finansowa przedsiębiorstwa przez analityka bankowego (wyd. II poprawione i rozszerzone). Warszawa: Oficyna Wydawnicza SGH. 


\title{
Rozdział VIII
}

\author{
AGNIESZKA PARKITNA*, ARKADIUSZ GÓRSKI**, \\ ANNA CZARNECKA ${ }^{* * *}$
}

\section{Nieetyczne zachowania biur maklerskich jako potencjalna bariera rozwoju rynku kapitałowego w Polsce}

\begin{abstract}
Bazą opisanych i przeprowadzonych badań w niniejszej pracy są niekorzystne dla inwestorów zachowania biur maklerskich, które w przekonaniu autorów pracy należy uznać za nieetyczne. Celem pracy było przeprowadzenie badania transakcji kupna-sprzedaży akcji dokonywanych w imieniu inwestora przez dom maklerski i wskazanie na zachowania podważające zaufanie do rynku kapitałowego, które cechuje nieetyczność oraz wskazanie na konsekwencje, do jakich mogą one doprowadzić. Dodatkowo starano się zaproponować regulacje, które mogłyby przyczynić się do zmniejszenia negatywnych zachowań biur maklerskich powodujących w konsekwencji odpływ kapitału i negatywne nastawienie drobnych inwestorów do inwestowania na rynku kapitałowym, co mogłoby pozytywnie wpłynąć na rozwój rynku kapitałowego.
\end{abstract}

Słowa kluczowe: etyka, rynek kapitałowy, bariery rozwoju.

* dr inż. Agnieszka Parkitna - Katedra Infrastruktury Zarządzania, Wydział Informatyki i Zarządzania, Politechnika Wrocławska, ul. Wybrzeże Wyspiańskiego 27, 50-370 Wrocław; e-mail: agnieszka.parkitna@pwr.edu.pl.

** dr niż. Arkadiusz Górski - Katedra Systemów Zarządzania, Wydział Informatyki i Zarządzania, Politechnika Wrocławska, ul. Wybrzeże Wyspiańskiego 27, 50-370 Wrocław; e-mail: Arkadiusz. gorski@pwr.edu.pl.

*** mgr Anna Czarnecka - Katedra Systemów Zarządzania, Wydział Informatyki i Zarządzania, Politechnika Wrocławska, ul. Wybrzeże Wyspiańskiego 27, 50-370 Wrocław; e-mail: anna. kilyk@pwr.edu.pl. 


\section{Unethical Brokerage Behavior as A Potential Barrier of The Capital Market Development in Poland}

The basis of this paper and the performed research is the existence of unfavorable for the investor behavior of brokerage houses, which in the authors' opinion should be regarded as unethical, and that ethics should be the base of capital market activity. The main goal of this paper is to analyze the buy-sell shares transactions, which is done by brokerage house on behalf of investor in order to indicate behaviors defined by authors as unethical and to show the consequences to which they can lead. In addition, authors propose some regulations that would help to reduce the negative behavior of brokerage houses, which result in capital outflow and negative attitude of small investors towards investing on the capital market which in return could also positively influence development of the capital market.

Keywords: ethics, capital market, development barriers.

JEL: E44, G24

\section{Wprowadzenie}

Rynek kapitałowy ma fundamentalne znaczenie dla rozwoju gospodarki rynkowej i wzrostu gospodarczego. Kluczowymi uczestnikami tego rynku są domy maklerskie. Ze względu na swoje znaczenie, jednostki te zobowiązane są do tworzenia i doskonalenia norm związanych z prowadzeniem działalności w sposób przejrzysty, umożliwiający zwiększenie bezpieczeństwa pozostałych uczestników rynku. Z tego też powodu określenie „dom maklerski” winno kojarzyć się z kompetencją, uczciwością czy też prawością wynikającą z przestrzegania prawa i zasad etyki prowadzonej działalności (Izba Domów Maklerskich, 2014). Reguły walki konkurencyjnej są bezwzględne. Nie powinny jednak być asumptem do tego, by rywalizację prowadzić według zasad niegodnych instytucji o oczekiwanym podwyższonym zaufaniu publicznym. Gospodarczy potencjał etyki jest bardzo różnorodny. Dziś społeczna odpowiedzialność podmiotów gospodarczych, za to co czynią i wedle jakich reguł działają, staje się czymś istotnym. To swoisty wyznacznik wizerunku firmy i podstawa jego etycznego działania (Klinek, 2014, s. 68-76).

Pomimo istnienia sporego zbioru regulacji (tj. Kodeks Dobrej Praktyki Domów Maklerskich, ustawa o przeciwdziałaniu nieuczciwym praktykom rynkowym) odnoszących się do funkcjonowania domów maklerskich, występują sytuacje, które nie służą rozwojowi rynku kapitałowego, a informacje o nich skłaniają inwestorów do poszukiwania innych możliwości inwestycyjnych niż 
przykładowo akcje w obrocie publicznym. Niestety należy przy tym podkreślić, iż za powstanie tego typu sytuacji odpowiadają głównie domy maklerskie i nie chodzi tutaj o sytuacje całkowicie poza prawem (jak chociażby wykorzystanie poufnych informacji zaburzających przejrzystość rynku), ale w szczególności o zachowania nieetyczne, które często są na pograniczu prawa.

\section{Sprzeczność interesów jako podstawa nieetycznych zachowań}

Zaufanie to przekonanie, że druga strona wypełni to, do czego się zobowiązała (Blomqvist, 1997). W pracę biur maklerskich wpisana jest sprzeczność interesów dwóch grup interesariuszy. Z jednej strony zobowiązani są do sprzedawania akcji, z drugiej zaś - rekomendują ich kupno. Taka sytuacja może doprowadzić do wygenerowania strat jednej ze stron transakcji. Istnienie takich zdarzeń może zaś doprowadzić inwestorów do wniosku, iż brokerzy świadomie próbują wprowadzić ich w błąd, co jest sprzeczne z zapisem zawartym w Kodeksie Dobrej Praktyki: § 3, pkt 2 „DM w prowadzonej działalności na rzecz osób trzecich zobowiązany jest zachować należytą staranność [...], § 4 [...] kieruje się on dbałością o bezpieczeństwo rynku w szczególności wprowadzając wewnętrzne zasady monitorowania transakcji oraz przeciwdziałania praktykom manipulacji instrumentami finansowymi" (Izba Domów Maklerskich, 2014). „Manipulacja na rynku” oznaczałaby zawieranie transakcji, które dają lub dawałyby fałszywe, wprowadzające w błąd sygnały dotyczące podaży, popytu oraz cen instrumentów kapitałowych (dyrektywa 2003/6/WE Parlamentu Europejskiego i Rady z dnia 28 stycznia 2003 r.; dalej: dyrektywa Market Abuse, 2003, art. 1 ust. 2; Fang i Ayako, 2014).

Celem usprawnienia działania rynków kapitałowych Unia Europejska wprowadziła dodatkowe regulacje prawne, które wspomagają podmioty raportujące w ocenie i wykrywaniu zleceń mogących posiadać znamiona manipulacji. Wśród kryteriów znajdujących się w tych regulacjach wymienić można (Banaszczak-Soroka i Zawadzka, 2008, s. 389-399):

- udział zlecenia w dziennym obrocie instrumentem finansowym na danym rynku;

- stopnień, w jakim zlecenia i transakcje powodują istotne zmiany ceny tego instrumentu;

- na ile zmieniający się w krótkich odstępach czasu udział zleceń w ofertach kupna przekłada się na udział w ofertach sprzedaży danego instrumentu;

- na ile składanie w krótkich odstępstwach czasu zleceń wywołuje krótkotrwałą zmianę ceny; 
- na ile zlecenia odwołane przed ich realizacją powodują zmiany w zakresie najlepszych ofert kupna lub sprzedaży instrumentu finansowego;

- na ile zlecenia składane w okresie wpływają na cenę danego instrumentu finansowego, na podstawie którego ustala się cenę lub dokonuje wyceny (ustawa o obrocie instrumentami finansowymi, 2005, art. 41 ust. 1).

\section{Etyka jako podstawa działalności na rynku kapitałowym}

Wprowadzane regulacje pozwalają znacząco ograniczać nieuczciwe działania podmiotów, które na rynku kapitałowym mają znaczną przewagę w stosunku do inwestorów, szczególnie tych drobnych. Jednakże regulacje te nie są w stanie zapobiec wszelkim negatywnym zachowaniom na rynku kapitałowym. Trudno bowiem wykazać osobie odpowiedzialnej za inwestowanie, że działała w złej wierze albo że przedkładała wyniki jednej transakcji nad drugą. Z tych też względów w działalności na rynku kapitałowym mocno podkreślana jest działalność etyczną, wymaganą w szczególności od podmiotów posiadających większe uprawnienia.

Literatura przedmiotu odnosi się do pojęcia „etyki” jako elementu koniecznego gospodarowania lub determinanty kształtującej cele organizacji. Pochylając się nad dorobkiem badaczy, warto przytoczyć spostrzeżenie, że „moralność jest zjawiskiem społecznym, a etyka jest dyscypliną naukową, która zajmuje się badaniem moralności” (Kawalec i Błachut, 2011, s. 54). Etyka, będąc jedną z gałęzi filozofii, ,jednocześnie ocenia praktyki ludzkie, odwołując się do standardów moralnych, jak i może także być źródłem preskryptywnych rad, jak postępować moralnie w określonych sytuacjach” (Pratley, 1998, s. 12). Warto zwrócić uwagę, że etyka biznesu cechuje się najwyższym poziomem abstrakcji. W kontekście ekonomicznym, są to „dziedziny, które rozważają kwestię racjonalności działań i ludzkich wyborów" (Klimczak i Lewicka-Strzałecka, 2007, s. 45). Ponadto „etyka biznesu jest częścią etyki gospodarczej”, niemniej jednak zdaniem niektórych autorów dość często, „określeń tych używa się zamiennie" (Kawalec i Błachut, 2011, s. 54).

Przedmiotem etyki jest badanie postępowania moralnego w dwóch wymiarach: jako „konwencjonalne sądy moralne lub faktyczne zachowania moralne” (Pratley, 1998, s. 12). „Refleksja nad moralnymi aspektami gospodarowania [dotyczy dwóch rzeczy] namysłu nad powinnością przedsiębiorstw oraz refleksji nad jego moralnymi wyborami” (Klimczak i Lewicka-Strzałecka, 2007, s. 45). W tych dwóch płaszczyznach etyka dostarcza narzędzi, które pomagają pogodzić cele ekonomiczne z celami etycznymi. „Moralność stanowi istotny czynnik wydajności społecznej samej ekonomii. Postrzeganie ekonomii jako 
nauki o ograniczoności zasobów i konieczności dokonywania racjonalnych i odpowiedzialnych wyborów pozwala stwierdzić, iż efektywność gospodarcza w postaci wypracowanego zysku staje się dla biznesmena obowiązkiem moralnym i formą realizacji odpowiedzialności społecznej” (Kawalec i Błachut, 2011, s. 54). W świetle podjętych rozważań można się zastanawiać czy każda decyzja i podjęte działanie, które realizuje postulat racjonalności i efektywności jest etyczne?

\section{Nieszczelne chińskie mury jako narzędzie zabezpieczające}

Biuro maklerskie oferujące akcje spółki wprowadzanej do obrotu giełdowego dąży do sytuacji, w której emisja akcji kończy się sukcesem, czyli znajdują się inwestorzy nabywający proponowane do zakupu walory. W celu zwiększenia powodzenia w sprzedaży akcji często wydaje ono raporty wyceniające atrakcyjnie sprzedawaną spółkę. Bycie jednocześnie sprzedającym i rekomendującym rodzi uzasadnione podejrzenia, że sprzedawany walor nie musi być tak atrakcyjny, jak się go rekomenduje. Aby uniknąć konfliktu interesów, w biurach maklerskich istnieją specjalne procedury uniemożliwiające współpracę między konkurującymi ze sobą departamentami. Procedury te określane są mianem tzw. chińskich murów (Rzeczpospolita, 2001). Każde biuro ma dodatkowo regulamin przepływu i kontroli informacji poufnych. Informacje takie nie mogą przedostawać się np. między działami zajmującymi się rynkiem pierwotnym i wtórnym, między działami sprzedaży i działami analiz (Brycki, 2001), o czym świadczy zapis Kodeksu Dobrej Praktyki: „§ 11 Dom Maklerski powinien dążyć do unikania konfliktu interesów ze swoimi klientami i § 14, punkt 1 . Przy realizowaniu zleceń klientów Dom Maklerski zobowiązany jest w szczególności: (pozycja 1) do realizowania zleceń klienta zgodnie z określonymi w nich warunkami i właściwą umową łączącą Dom Maklerski z klientem, oraz podkreśla się, że (punkt 2. Pozycja 1) niedopuszczalne jest: uprzywilejowanie zleceń na własny rachunek Domu Maklerskiego w stosunku do zleceń klientów” (Izba Domów Maklerskich, 2014).

Regulaminy zatwierdzane i egzekwowane przez Komisję Papierów Wartościowych i Giełd dotyczą wszystkich biur maklerskich, a więc - jak można się domyślić - we wszystkich istnieją „,chińskie mury” oddzielające wydziały, między którymi nie może dojść do przepływu informacji. Rekomendacje domów maklerskich każą jednak zastanowić się czy w Polsce są one rzeczywiście szczelne.

Nadzór ze strony państwa służy prawidłowemu funkcjonowaniu rynku kapitałowego, zapewniając bezpieczeństwo obrotu środkami zainwestowanymi przez jego uczestników. Zadanie to realizowane jest przez wysokiej rangi 
organ administracji państwowej. W Polsce pieczę nad prawidłowym funkcjonowaniem rynku sprawuje Komisja Nadzoru Finansowego (KNF). Ponieważ rynek kapitałowy nie jest wolny od nadużyć i nieprawidłowości, przewodniczący Komisji posiadający uprawnienia prokuratora może uczestniczyć, jako oskarżyciel, w postępowaniach dotyczących przestępstw na rynku finansowym. Dodatkowo na stronie internetowej KNF zamieszczane są ostrzeżenia publiczne mające na celu zapobieganie wprowadzaniu w błąd, a w efekcie końcowym narażaniu na straty uczestników rynku finansowego w wyniku oszustwa (Komisja Nadzoru Finansowego, czyli..., 2008).

W Polsce rzadko można usłyszeć o przypadkach pozywania instytucji finansowych, co także wynika poniekąd z niedoskonałości prawa, ale jest konsekwencją stopnia rozwoju rynku kapitałowego. W Stanach Zjednoczonych żadna spółka nie pozwoli sobie na opublikowanie nierealnych prognoz finansowych, ponieważ wprowadzanie w błąd inwestorów owocuje pozwami do sądów. Głównym umocowaniem prawnym dla tego rozwiązania jest ustawa SarbanesaOxleya (Sarbanes-Oxley Act, 2002).

W warunkach, gdy istnieje bardzo duża ilości narzędzi do komunikacji oraz dokonywane są transakcje na znaczne kwoty, dobre intencje ustawodawców nie mają szans przełożyć się na realia gospodarcze. Świadczyć o tym mogą chociażby wyniki badań prowadzone na Uniwersytecie w Michigan, w których przeanalizowano kilka dekad działalności instytucji finansowych oraz wpływ potencjalnych „dziur” w chińskich murach na wyniki portfeli insiderów (osób oraz instytucji posiadających dostęp do informacji poufnych). Ze względu na znaczne różnice między wynikami uzyskanymi przez „wtajemniczonych” a „niewtajemniczonych” śmiało można stwierdzić, że chińskie mury są rozwiązaniem bezużytecznym (Hollander i Salzedo, 2003). Oznacza to, że „trefny towar" w postaci przewartościowanych akcji jest zazwyczaj sprzedawany szerokiej publiczności w czasie, w którym pozbywa się ich firma rekomendująca, na przykład klientom private banking/asset management. Jest to kolejne potwierdzenie tezy o jedynie fasadowej roli „,chińskich murów” w instytucjach finansowych, w tym bankach inwestycyjnych (Szczepański, 2009).

Wierzbowski, Sobolewski i Wajda w komentarzu do prawa rynku kapitałowego zwracają uwagę, iż ,przepis art. 83a ustawy o obrocie instrumentami finansowymi został poświęcony tzw. chińskim murom (ust. 1) oraz - żywo dyskutowanemu i różnie rozumianemu - spoczywającemu na firmie inwestycyjnej obowiązkowi działania z uwzględnieniem najlepiej pojętego interesu klienta" (Wierzbowski, Sobolewski i Wajda, 2014).

Teoretycznie kontrolne instytucje państwowe mogą nakładać kary na spółki za wprowadzanie w błąd inwestorów. Reakcją emitentów było jednak ogra- 
niczenie liczby prognoz. Wydaje się, że amerykańskie prawo znacznie lepiej niż polskie chroni drobnych inwestorów, ponieważ trudno oczekiwać, aby polski inwestor mógł się domagać rekompensaty za stratę pieniędzy w przypadku inwestycji zgodnych z rekomendacją. Integralną częścią raportu analitycznego jest zapis, „iż broker nie bierze odpowiedzialności za finansowe skutki rekomendacji”. W końcowej części tych raportów znajduje się także informacja, iż opracowanie zostało sporządzone wyłącznie w celu informacyjnym i nie jest próbą reklamy ani oferowania papierów wartościowych, a odpowiedzialność za skutki decyzji podjętych na podstawie rekomendacji ponoszą wyłącznie inwestorzy (Brycki, 2001).

\section{Badania zachowań maklerskich}

Wniesienie przez inwestora pozwu przeciw podmiotowi odpowiedzialnemu za zarządzanie jego aktywami (bądź brokerowi) za straty, jakie poniósł on w wyniku nietrafionych prognoz czy też podejrzanych decyzji, wiąże się z długotrwałym procesem. Polega on przede wszystkim na dochodzeniu racji, a w szczególności na wykazaniu związku przyczynowo-skutkowego między podjętymi decyzjami a wynikiem zarządzanego portfela inwestycyjnego. Natura inwestycji kapitałowych dodatkowo wprowadza tutaj trudności dowodowe, gdyż podjęcie jakiejkolwiek decyzji inwestycyjnej zawsze narażone jest na stratę. W efekcie doradca inwestycyjny może bronić każdej swojej decyzji w zakresie kupna i sprzedaży, niezależnie od poziomu straty, do jakiego ona doprowadziła.

Mając na celu ocenę etyki zachowań biur maklerskich, przeprowadzono badania obejmujące przeanalizowanie wybranych kilkudziesięciu transakcji zawieranych $w$ ramach usługi zarządzania portfelem inwestycyjnym dokonywanych przez dom maklerski, a które to transakcje były zawierane w latach 2009-2011. Ze względu na ochronę informacji poufnych nie będą wskazywane konkretne decyzje inwestycyjne, a także żadne informacje o badanym domu maklerskim, inwestorze czy też spółkach, których akcje były przedmiotem obrotu. Nie było również celem pracy określenie skali rozważanego zjawiska, co może być przedmiotem pogłębionych i dalszych badań. W pracy znajdą się natomiast wnioski wynikające $\mathrm{z}$ przeprowadzonych analiz wraz $\mathrm{z}$ wybranymi danymi liczbowymi.

Poniżej sformułowano deliberacje wyciągnięte w prowadzonych badań, które to niestety skupiają się głównie na zaobserwowanych trzech niekorzystnych zjawiskach:

a) inwestowaniu w walory powiązane $\mathrm{z}$ domem maklerskim; 
b) lokowaniu kapitału w nietrafione walory niezgodne $\mathrm{z}$ obserwacją ryzyka rynku - brak zarządzania portfelem akcji wykorzystującym alerty sprzedażowe;

c) ukrytej „manipulacji” rynkiem.

\subsection{Inwestowanie $w$ walory powiązane $z$ domem maklerskim}

Większość (ponad 80\%) z dokonanych przez dom maklerski, w okresie objętym badaniem, inwestycji dotyczyła walorów spółek, które ten sam dom maklerski upubliczniał. Spółki te będą określane jako powiązane (zamiennie walory lub spółki). Biorąc pod uwagę, że pojedynczy dom maklerski ma udział w emisjach na poziomie 5-10\% struktura dokonywanych inwestycji jest w tym przypadku rażąco niekorzystna z punktu widzenia obiektywizmu inwestowania. Można oczywiście doszukiwać się pozytywnych stron w inwestowaniu w walory, co do których posiada się znaczną wiedzę, jednakże skupianie się praktycznie na tych walorach niekoniecznie może być korzystne dla inwestora - właściciela zarządzanego przez dom maklerski portfela. $Z$ pewnością można uznać, że atutem inwestowania w spółki powiązane jest pełna, bezpośrednia wiedza o spółce. Jednakże pojawia się tutaj konflikt interesów, który jest niezaprzeczalny.

Konflikt interesów nie oznacza jednoznacznie, że może on negatywnie wpłynąć na wynik zarządzania portfelem. W tym przypadku można nawet zakładać, że dom maklerski jest dobrze rozeznany w sytuacji spółki, szczególnie w analizie jej wyników oraz jakości i dokładności opracowanych prognoz. Skłania to do wniosku, że podejmowane decyzje w zakresie kupna i sprzedaży powiązanych walorów będą jak najbardziej właściwe. I z pewnością można się zgodzić z tego typu rozumowaniem, gdyby nie konflikt interesów, który może prowadzić dom maklerski do dbania wyłącznie o własny interes i stawienie go wyżej niż interes właściciela portfela. Oczywiście dom maklerski może stwierdzić, że zależy mu wyłącznie na tym, aby wynik na zarządzanym portfelu inwestycyjnym był dodatni, bo przecież zarabia określony procent od wypracowanego zysku. Problem pojawia się jednak w sytuacji, w której konflikt interesu polega na tym, że ewentualne zyski z zarządzanych portfeli inwestycyjnych przez dom maklerski mogą zostać poświęcone na rzecz korzyści uzyskiwanych z upubliczniania określonych walorów. Skutkami uwikłania w konflikt interesu mogą być następujące zachowania, które powodują, że dom maklerski:

- nie dokonuje analizy możliwości inwestycyjnych, tylko skupia się na walorach powiązanych;

- nie wybiera najlepszych możliwości inwestycyjnych tylko wybiera walory powiązane; 
- nie ocenia walorów powiązanych w sposób obiektywny;

- obciąża ocenę walorów powiązanych własną, często optymistyczną opinią;

- środki z zarządzanych portfeli wykorzystuje do zapisu na upubliczniane powiązane walory, co zwiększa zainteresowanie nimi na rynku kapitałowym;

- ślepo wierzy w nieomylność opracowanych i zaakceptowanych prognoz dla powiązanej spółki;

- celowo nie wychodzi z inwestycji w prowadzone na rynek kapitałowy walory, aby nie pogłębić ewentualnego ich trendu spadkowego.

Przedstawione skutki są hipotetyczne, jednakże jak najbardziej realne i prawdopodobne. Oczywiście trudno je jednoznacznie potwierdzić, bo leży to niestety głównie w gestii domu maklerskiego, który musiałby ujawnić swoje rzeczywiste zamiary.

\subsection{Lokowanie kapitału $w$ nietrafione walory niezgodne $z$ obserwacją ryzyka rynku - brak zarządzania portfelem akcji wykorzystujące alerty sprzedażowe}

W większości analizowanych inwestycji dokonywanych przez dom maklerski nie opierano się na żadnych progach straty lub zysku (np. progu 20\% straty lub $15 \%$ zysku), które mogłyby stanowić punkt krytyczny określony jako sygnał wyprzedaży posiadanego waloru. Decyzja o sprzedaży waloru była podejmowana przez grono doradców inwestycyjnych jednakże trudno zdefiniować stosowane w tym zakresie reguły, tym bardziej że podejmowane decyzje były czasami niezgodne z wewnętrznymi rekomendacjami. Na podstawie przeanalizowanych kilkudziesięciu decyzji podjętych przez dom maklerski można wręcz stwierdzić, że zarządzanie portfelem sprowadzało się do zakupu walorów, pozostawienia ich na rachunku i incydentalnym podejmowaniu decyzji o ich sprzedaży. Wydaje się, że w przypadku niekorzystnej tendencji zmian ceny zakupionych walorów dom maklerski czekał na odwrócenie tendencji (Shefrin i Statman, 1985, s. 777-790). Przy braku założonych alertów sprzedażowych, w niektórych przypadkach przekraczane były kolejne poziomy straty, które powinny skłaniać nie tylko do refleksji, lecz także do działania. W efekcie czego niektóre inwestycje na walorach powiązanych zostały zamknięte ze stratami dochodzącymi do $90 \%$, pomimo że zmiany cen nie były gwałtowne (tak znaczący spadek cen nie nastąpił w ciągu kilku dni, był to bowiem proces kilkumiesięczny). Zarządzający portfelem nie może czekać na przełamanie negatywnego trendu, licząc na odrobienie straty, gdyż jego celem jest zarabianie, a nie wiara w poprawę wyniku. Porażka inwestycyjna jest rzeczą jak najbardziej normalną i do zaakceptowania, jednakże nie można dopuszczać do pogłębiania straty. 
Nietrafione decyzje należy zamknąć po przekroczeniu założonego pułapu straty i podejmować nowe decyzje, które pozwolą na odrobienie tych strat, a nie przetrzymywać, licząc na odbicie (Czerwonka i Gorlewski, 2012, s. 81). Jednakże w przypadku przekroczenia określonego progu zysku należy go zrealizować i szukać kolejnych inwestycji, które te zyski powiększą.

Dość charakterystyczną specyfiką rynku kapitałowego jest fakt, że spadki czy też wzrosty zazwyczaj przebiegają pochyłą linią sinusoidalną. Po spadkach dochodzi do odbicia cen, po nagłych wzrostach pojawiają się korekty, które w gruncie rzeczy nie przełamują trendu spadkowego lub wzrostowego. Dlatego też powinny być stosowane progi sprzedażowe, które teoretycznie pozwolą na uzyskanie mniejszej straty, a być może pozwolą nawet na uzyskanie zysków. Przykładowo, przeanalizowano możliwą inwestycję w latach 2011-2012, w akcje spółki KGHM, dla których kurs zamknięcia na 11 sierpnia 2011 r. wynosił 161,9 zł - załóżmy, że za tyle kupuje się akcje tej spółki. W połowie września i na początku października w wyniku spadku zainteresowania akcjami spółki pojawiają się straty w wysokości ponad $20 \%$, sygnał ten zmusza do zastanowienia się, co dalej robić z akcjami tej spółki, ze szczególnym wskazaniem na ich sprzedaż ze względu na nietrafioną decyzję inwestycyjną. W tym przypadku rozpatrzyć można dwa scenariusze:

1. Inwestor sprzedaje akcje. Sprzedaż całości posiadanych akcji w momencie pojawienia się alertu może być utrudniona lub może wymagać czasu. W przypadku tego scenariusza podjęte działania pozwalają jednak przypuszczać, że poziom straty nie będzie dużo większy od przyjętego alertu wyprzedaży. Czasami, w sytuacji sinusoidalnego odbicia, poziom straty może być nawet niższy.

2. Postępowanie analogiczne do zachowań badanego domu maklerskiego - przetrzymanie całościowego pakietu akcji i czekanie na zmianę trendu. Takie postępowanie wiąże się z ignorowaniem ryzyka spadku wartości inwestycji powyżej 20\% wyjściowej wartości inwestycji. Przeprowadzając analizę post fatum i przyglądając się kształtowaniu ceny akcji, w założonym okresie, w najgorszym momencie sprzedaż akcji mogłaby się dokonać np. w grudniu 2011 roku, wówczas cena akcji była po około 107 zl, czyli strata z inwestycji wyniosłaby w przybliżeniu $34 \%$.

Oceniając dokonywane przez dom maklerski transakcje kupna-sprzedaży można było odnieść wrażenie, że lepszy efekt dałby ślepy los. Umowa o zarządzanie aktywami zobowiązuje jednak dom maklerski do profesjonalnego działania, a nie do ślepego administrowania, powinny więc być podejmowane działania mające na celu optymalizowanie wyników uzyskiwanych przez port- 
fel, a nie ograniczające się wyłącznie do zakupu powiązanych ze sobą walorów i czekania. Takie działanie niestety każe powątpiewać w etyczność działań domu maklerskiego. Co może prowadzić do sformułowania zarzutu, iż dom maklerski sztucznie utrzymuje kurs walorów ze sobą powiązanych kosztem swoich klientów. Obawiając się utraty wiarygodności, w momencie gdy wprowadzany przez dom maklerski na rynek kapitałowy walor traciłby na wartości już od początku notowań, co szczególnie może być odczuwalne na rynku mniej płynnym, za jaki można uznać rynek NewConnect. Wyprzedaż zbyt dużej liczby akcji na mało płynnym rynku mogłaby doprowadzić do znacznego spadku wartości tych akcji. Ta oczywista prawidłowość mogła wpływać na zachowanie domu maklerskiego. Dlatego też należy podkreślić, że dom maklerski, zarządzając portfelem, nie powinien kupować znacznych ilości walorów powiązanych, jest to bowiem operacja ryzykowna dla inwestora ze względu na wskazany konflikt interesów i możliwość podejmowania decyzji niezgodnych z interesem inwestora. Działania takie mają jednak miejsce i są traktowane jako dopuszczalne, a biorąc pod uwagę przekroczenie granic konfliktu interesów mogą wyraźnie i znacząco wpływać na uzyskaną przez inwestora stratę.

\section{Ukryta "manipulacja” rynkiem}

Oceniając transakcje dokonywane przez dom maklerski w badanym okresie można wręcz postawić tezę, iż prowadzono ukrytą manipulację rynkiem. Dlaczego ukryta i na czym ma polegać ta manipulacja? Otóż dom maklerski zarządza portfelem inwestora. W efekcie rynek widzi zachowania inwestora, a nie domu maklerskiego (Stickel, 1995). Dom maklerski zarządzający dużą ilością portfeli inwestycyjnych, ograniczając się tylko do nieznacznej części środków z każdego portfela, jest w stanie uzyskać łącznie znaczną kwotę środków, które przeznaczyć może na dokonanie zakupów czy też zapisów na walory powiązane. W efekcie tych działań dom maklerski może wyraźnie wpływać na zachowania na rynku kapitałowym, poprzez prowokowanie popytu na wybrane walory, a w szczególności na walory powiązane. W przypadku takiego kształtowania popytu mało kto jest świadomy, że za zaistniałą sytuacją stoi ten sam dom maklerski. Inwestorami może być bowiem wiele podmiotów, których środkami zarządza jeden dom maklerski.

Przedstawione wnioski stanowią wynik rozważań autorów i są w efekcie zbiorem stawianych hipotez wynikających z przeprowadzonych badań. W odbiorze i samodzielnej ocenie przedstawionych wniosków mogą pomóc informacje o efektywności zarządzania badanym portfelem oraz wybrane statystyki rynku w okresie prowadzonych badań. 
1. Wynik na zarządzanym badanym portfelu akcji był ujemny i przekroczył $50 \%$ stratę.

2. Analiza ex post wykazała, że hipotetyczny wynik przy sprzedaży w optymalnym momencie, w okresie pomiędzy zakupem a ostateczną sprzedażą poszczególnych walorów, mógłby być dodatni i mógłby osiągnąć około $15 \%$.

3. Inwestycje w spółki powiązane były przeważające i odnosiły się głównie do rynku pierwotnego, dlatego też przeanalizowano różne statystyki odnoszące się do debiutów giełdowych w badanym okresie. Statystyki dotyczące debiutów (IPO) na rynku kapitałowym w okresie prowadzonych badań przybliża tabela 1 .

Ta b e la 1. Statystyki debiutów (IPO) giełdowych

\begin{tabular}{|l|r|}
\hline Średnia stopa zwrotu na debiucie ze wszystkich spółek & $44,86 \%$ \\
\hline Lączna liczba debiutów & 136 \\
\hline Liczba debiutów z zyskiem & 97 \\
\hline Liczba debiutów ze stratą & 15 \\
\hline Maksymalna strata & $-24,50$ \\
\hline Średnia strata & $-5,81 \%$ \\
\hline
\end{tabular}

Źródło: opracowanie własne.

Uwzględniając prawa do akcji (PDA), statystyki dla tak zdefiniowanych debiutów (IPO plus PDA) uzupełniają powyższe informacje, jednak nie zmieniają znacząco oceny kształtowania się rynku, a przedstawiają się zgodnie $\mathrm{z}$ danymi przedstawionymi $\mathrm{w}$ tabeli 2 .

Ta be l a 2. Statystyki debiutów (IPO) giełdowych oraz praw do akcji (PDA)

\begin{tabular}{|l|r|}
\hline Średnia stopa zwrotu na debiucie ze wszystkich spółek & $34,65 \%$ \\
\hline Łączna liczba debiutów & 222 \\
\hline Liczba debiutów z zyskiem & 169 \\
\hline Liczba debiutów ze stratą & 39 \\
\hline Maksymalna strata & $-24,50$ \\
\hline Średnia strata & $-5,29 \%$ \\
\hline
\end{tabular}

Źródło: opracowanie własne.

Przedstawiony materiał wyraźnie pokazuje, iż ograniczając się do debiutów, a na tego typu inwestycjach bazowano w badanym portfelu inwestycyjnym, można było uzyskać dość atrakcyjną stopę zwrotu, średnio minimum około $35 \%$, gdy bazujemy na IPO plus PDA. Oczywiście specyfika inwestowania 
powoduje, że nawet przy satysfakcjonującej średniej z rynku można podnieść stratę w wyniku inwestowania w „pechowe” spółki. Powierzając zarządzanie aktywami specjalistom, można oczekiwać, że prawdopodobieństwo pecha inwestycyjnego powinno spaść do minimum. Poza tym, poziom straty przy wyborze wyłącznie „niewłaściwych” spółek nie powinien przekroczyć 50\%, tak jak wyniosła efektywność inwestycji badanego domu maklerskiego.

Jeżeli dom maklerski stracił w wyniku swojego zarządzania około $50 \%$ zainwestowanego przez inwestora kapitału, zamiast statystycznie zarobić, stosując się wyłącznie do strategii debiutów, to należy zastanowić się co było tego przyczyną:

- może dom maklerski miał „strasznego pecha”;

- może nie dochował należytej staranności przy zarządzaniu portfelem akcji;

- może zarabianie na rzecz swojego klienta, czyli inwestora nie było w tym momencie w jego pierwszoplanowym interesie?

Autorzy uważają, że przyczyna bardzo złego wyniku na zarządzaniu portfelem inwestycyjnym przez dom maklerski tkwi w nieetycznych zachowaniach domu maklerskiego. Hipotetycznie można wręcz założyć, że dom maklerski nie wykonał swoich obowiązków związanych z podpisaną umową o zarządzanie, tylko wykorzystał środki inwestora do innych celów, stawiając na drugim miejscu efektywność inwestycji prowadzonej na rzecz inwestora.

Otóż dom maklerski jako podmiot pośredniczący we wprowadzaniu nowych spółek na giełdę zarabia głównie w momencie doprowadzenia do udanej emisji akcji. O udanej emisji akcji można mówić w momencie, gdy znajdą się klienci na akcje wprowadzanego na giełdę podmiotu gospodarczego (a to nie zawsze ma miejsce). Dom maklerski, pozyskując nową spółkę do wprowadzenia na giełdę, mógł wręcz częściowo zagwarantować, że znajdzie nabywców na jej akcje, wykorzystując w tym celu powierzony przez inwestorów kapitał. Dom maklerski mógł nawet nie myśleć o kupowaniu innych spółek, gdyż wówczas nie miałby w zanadrzu środków na zakup akcji spółek wprowadzanych na giełdę przez siebie, a przez to mogłaby nie powieść się emisja akcji, a tym samym nie zarobiłby na niej. A tak, jeżeli brakowało inwestorów zainteresowanych zakupem akcji powiązanych spółek dom maklerski mógłby zakupić te akcje za pieniądze powierzone przez inwestorów, na rzecz których świadczył doradztwo inwestycyjne. Niejasna sytuacja uzasadniać może również przyczynę strat na dokonywanych inwestycjach oraz sztucznego zawyżania ceny spółek IPO (Lizińska i Czapiewski, 2015, s. 112-125).

Konflikt interesów może równocześnie uzasadniać powściągliwość domu maklerskiego w wyprzedaży akcji powiązanych w przypadku negatywnego tren- 
du zmiany ich cen i niestosowania się do alertów wyprzedażowych. Otóż dom maklerski, działając w imieniu inwestora, nie mógł, czy też dokładnie - nie chciał rezygnować za szybko z inwestycji w akcje powiązane, gdyż jako emitent, a zarazem doradca rekomendował dla rynku kapitałowego i właścicieli wprowadzanej spółki określoną cenę sprzedaży. Jeżeli po emisji dom maklerski nagle realizowałby na rzecz inwestora, którego portfelem zarządzał, zyski z tych akcji i zdecydowałby się na ich sprzedaż, mogłoby to spowodować spadek ich cen, jak i zainteresowania innych inwestorów. Byłoby to z kolei źle odebrane przez rynek i rzuciło się cieniem na ocenę domu maklerskiego odpowiedzialnego za wprowadzenie na giełdę spółki powiązanej.

$\mathrm{Z}$ tych też względów dom maklerski, być może, aby sztucznie podtrzymywać cenę akcji, mógł środkami z zarządzanych portfeli dokonywać zakupu akcji powiązanych na wolnym rynku już po ich wprowadzeniu na giełdę. Dlaczego? Celem dodatkowego zapewnienia ich płynności i podtrzymania ceny waloru powiązanego lub ograniczenia spadku ich cen, licząc, że w przyszłości trend się odwróci i odrobi straty, na jakie w efekcie swoimi działaniami naraził inwestora, o którego interes powinien dbać zgodnie z podpisaną umową o zarządzanie.

\section{Nieetyczne zachowania jako bariera rozwoju rynku kapitałowego - wnioski}

Przeprowadzone przez autorów badania skłaniają do refleksji nad etyką zachowań biur maklerskich. Autorzy zwrócili uwagę na istnienie procederu opisanych negatywnych zachowań w świetle przeprowadzonych badań, które ze wszech miar można uznać za nieetyczne.

W roku 2015 za główne bariery rozwoju polskiego rynku kapitałowego uznano ograniczony dopływ kapitału, brak zrozumienia zasad działania rynku oraz awersję do ryzyka i preferowane oszczędzanie w banku (Błasiński, 2015). Opisane w badaniach przykłady zachowań nieetycznych mogą prowadzić do utraty zaufania klientów, co w konsekwencji może negatywnie wpłynąć na budowanie wizerunku rynku kapitałowego u inwestorów. „A jedną z podstaw budowania zaufania do rynku kapitałowego i instytucji w jego obrębie jest konieczność kształtowania kultury inwestowania przy jednoczesnym budowaniu świadomości w zakresie rynku kapitałowego" (GPW, 2014).

W prawodawstwie polskim powinna istnieć zasada, że dom maklerski odpowiada za wszystkie nieuprawnione inwestycje, w szczególności za inwestycje związane z konfliktem interesów. W rzeczywistości, to pojedynczy inwestor musi udowadniać pojawienie się nieprawidłowości w działaniach domów maklerskich, co często bywa dość trudne, a samo stwierdzenie naruszenia 
umowy przez dom maklerski nie uprawnia inwestora do odszkodowania, gdyż należy wykazać związek przyczynowo-skutkowy, co na rynku kapitałowym ze względu na jego specyfikę jest bardzo trudne.

Przedstawione w pracy zachowania biur maklerskich, które autorzy określają jako nieetyczne, są dopuszczalne przez polskie ustawodawstwo, o ile nie zostanie wykazane działanie sprzeczne $\mathrm{z}$ interesem inwestora. Niestety pomimo podejmowanych prób ograniczania możliwości nieetycznego zachowania, stale rozwijający się rynek kapitałowy będzie dostarczał coraz to nowszych furtek domom maklerskim. Wśród rozwiązań, które mogłyby częściowo ograniczyć zakres oraz liczbę możliwości nieetycznych zachowań, zaproponować można choćby dopracowanie umów między domami maklerskimi i inwestorami, nałożenie ograniczenia na zakup przez dom maklerski emitowanych przez niego akcji czy wprowadzenie częstszych i dokładniejszych kontroli KNF-u, badających transakcje nie tylko pod względem formalnym, lecz także doszukujących się ukrytych intencji oraz ewentualnych korzyści z ignorowania konfliktu interesu. Oczywiście nie należy oczekiwać, że same te zmiany „poprawią” zachowania biur maklerskich. Ograniczenie możliwości działań nieetycznych powinno pozytywnie wpłynąć na rozwój rynku kapitałowego, w przeciwnej sytuacji znaczna część drobnych inwestorów całkowicie odwróci się od rynku kapitałowego.

Niniejszą pracę należy traktować jako przyczynek do dalszej dyskusji i poszukiwania rozwiązań, które pozwolą na bardziej przejrzyste i etyczne funkcjonowanie rynku kapitałowego.

\section{Bibliografia}

Banaszczak-Soroka, U. i Zawadzka, P. (2008). Ochrona rynku kapitałowego przed manipulacją w zjednoczonej Europie. W: J. Kundera (red.), Integracja gospodarcza - od wolnego handlu do unii walutowej. Materiały Konferencji Międzynarodowej, Wrocław.

Blomqvist, K. (1997). The many face of trust. Scandinavian Journal of Management, 3.

Błasiński, M. (2015). Nowe spojrzenie na strategię rozwoju rynku kapitałowego. Parkiet com. Pozyskano z: http://www.parkiet.com/artykul/1408797.html.

Brycki, G. (2001). Czy chińskie mury są szczelne. Rzeczpospolita. Pozyskano z: http://newarch.rp.pl/artykul/350063_Czy_chinskie_mury_sa_szczelne.html.

Czerwonka, M. i Gorlewski, B. (2012). Finanse behawioralne. Zachowania inwestorów i rynku. Warszawa: SGH.

Dyrektywa 2003/6/WE Parlamentu Europejskiego i Rady z dnia 28 stycznia 2003 r. w sprawie wykorzystywania poufnych informacji $i$ manipulacji na rynku (Dz. Urz. UE L 96 z 12.04.2003, s. 16 ze zm.).

Fang, L. i Ayako, Y. (2014). Are Stars' Options Worth More? The relation Between Analyst Reputation and Recommendation Values. Journal of Financial Services Research, 46(3). 
GPW. (2014). Strategia Giełdy Papierów Wartościowych w Warszawie na lata 2014-2020. Warszawa: Giełda Papierów Wartościowych w Warszawie S.A. Pozyskano z: https://static. gpw.pl/pub/files/PDF/prezentacje/GPW2020_Strategia_PL.pdf.

Hollander, Ch. i Salzedo, S. (2003). Conflicts of interest \& Chinese Walls. Chinese walls' fail to curb conflicts of interest in securities firms By Bernie DeGroat News Service The university record of Line. University of Michigan wew service. Pozyskano z: uhttp://www. ur.umich.edu/0203/Feb17_03/07.shtml

Izba Domów Maklerskich. (2014). Kodeks dobrej praktyki domów maklerskich. Pozyskano z: http://www.idm.com.pl/images/regulacje/Kodeks_dobrej_praktyki_domow_maklerskich. pdf.

Kawalec, P. i Błachut, A. (2011). Odpowiedzialność spoteczna w innowacyjnej gospodarce. Lublin: Wydawnictwo KUL.

Klimczak, B. i Lewicka-Strzałecka, A. (2007). Etyka i ekonomia. Warszawa: Wydawnictwo Polskiego Towarzystwa Ekonomicznego.

Klinek, J. (2014). Zaufanie i spoteczna odpowiedzialność w biznesie. W: I. Hejduk, A. Herman, Dla przyszłości. Warszawa: Difin.

Komisja Nadzoru Finansowego, czyli stróż rynku kapitałowego. (2008). Bankier.pl. Pozyskano z: http://www.bankier.pl/wiadomosc/Komisja-Nadzoru-Finansowego-czyli-stroz-rynkukapitalowego-1710275.html.

Lizińska, J. i Czapiewski, L. (2015). Determinanty underpricingu w Polsce i na innych wybranych rynkach wschodzących. Prace Naukowe UE we Wroctawiu, Efektywność - rozważania nad istota i pomiarem, $\mathrm{Nr} 386$, Wrocław.

Pratley, P. (1998). Etyka w biznesie. Warszawa: Wyd. Gebethner i Ska.

Sarbanes-Oxley Act. (2002). The U.S. Government Publishing Office (GPO). Public Law 107-204, July 30. Pozyskano z: http://www.gpo.gov/fdsys/pkg/PLAW-107publ204/contentdetail.html.

Shefrin, H. i Statman, M. (1985). The Disposition to Sell Winners Too Early and Ride Loseres Too Long: Theory and Evidence. Journal of Finance, 40.

Stickel, S. (1995). The Anatomy of the Performance of Buy and Sell Recommendations. Financial Analysts Journal, 51(5).

Szczepański, K., (2009). Bankowość inwestycyjna - opis branży oraz studium przypadku Goldman Sachs, biznes i firma. Pozyskano z: http://www.biznes-firma.pl/bankowoscinwestycyjna---opis-branzy-oraz-studium-przypadku-goldman-sachs/14420.

Ustawa z dnia 29 lipca 2005 r. o obrocie instrumentami finansowymi (Dz.U. 2005 Nr 183, poz. 1538). 


\title{
Rozdział IX
}

\author{
ANDRII CHLECHKO* \\ The Analysis of the Impact \\ of Capital Mobility \\ on Bubbly Episodes Creation \\ in the Controlled Laboratory Environment
}

The author has developed a stylized experimental model which is used to analyze the impact of the introduction of capital mobility on the asset price behavior in the controlled laboratory environment. The introduction of capital mobility is subject to financial friction in the form of borrowing costs and collateral borrowing. The model is based on SSW-type double-auction market with a finite horizon. The division of the analyzed population into productive and unproductive investors creates an environment in which the structure of capital mobility tends to impact overall market efficiency. The overall combination of presented factors allows the author to analyze market efficiency based on the deviation of the market traded price over the expected average value of the assets.

Keywords: laboratory experiment, financial friction, bubble, capital mobility, market efficiency.

\section{Analiza wpływu płynności kapitału na tworzenie baniek finansowych w kontrolowanym środowisku laboratoryjnym}

Autor opracował kontrolowane środowisko eksperymentalne, które służy do analizy wpływu wprowadzenia mobilności kapitału na zachowanie cen aktywów. Mobilność kapitału jest wprowadzona poprzez możliwość zaciągania pożyczek pod zastaw akcji obciążonych kosztami frykcyjnymi. Model jest oparty na rynku podwójnych aukcji typu SSW (Smith, Suchanek and Williams, 1998) w określonych przedziałach czasowych. Podział analizowanej populacji na

Andrii Chlechko - B.Sc.; e-mail address: chlechko.andrii@gmail.com. 
inwestorów produktywnych i nieproduktywnych tworzy otoczenie, w którym struktura mobilności kapitałowej ma tendencję do wywierania wpływu na ogólną efektywność rynku. Połączenie prezentowanych czynników pozwala autorowi na analizowanie odchylenia ceny rynkowej w stosunku do oczekiwanej średniej wartości aktywów i wyciągnięcie wniosków dotyczących efektywności rynku. Wyniki eksperymentu pokazują, że wprowadzenie mobilności kapitału ma pozytywny wpływ na efektywność rynku kapitałowego. Cena rynkowa aktywów ma najmniejsze odchylenie w modelu bez kosztów frykcyjnych.

Słowa kluczowe: eksperyment laboratoryjny, koszty frykcyjne, bańka finansowa, płynność kapitałowa, efektywność rynku.

JEL: G40, G17, G10, C90, C92, C71

\section{Introduction}

The imperfection in asset pricing, to be more precise, the existence of bubbly episodes has attracted a lot of attention from both practitioners and theorists of financial analysis. Despite the common knowledge of the law of demand and supply, the actual equilibrium is a rare phenomenon in real economy. What is described in details in theory does not necessarily apply in practice. Economic decisions are not always rational, which can be seen as one of the main factors leading to market inefficiencies that cause financial bubbles.

According to Brunnermeier and Oehmke (2012), existing historical financial data suggest that financial bubbles existed at all times of human history at all stages of economic development (for a more detailed analysis of the history of bubbly episodes, please see Chancellor, 1999; Kindleberger, 2001). The most famous historical bubbles are dated as far back as the $17^{\text {th }}$ and $18^{\text {th }}$ centuries: Dutch Tulip Bubble (1634-1637), Mississippi Bubble (1719-2720) and South Sea Bubble (1720).

The current stage of economic science suggests two major types of analysis of bubbly episodes: theoretical and practical. The theoretical approach to the analysis of financial bubbles varies significantly in terms of applied tools and obtained results. A significant number of existing scientific papers represent various models which analyze the reasons for the appearance of bubbly episodes, their dynamics and the factors which may eliminate the existence of financial bubbles. Even though the models provide reasonable evidence from the scientific point of view, it is difficult to assess how they match with behavioral finance of the real economy. While the theoretical analysis has been conducted for the whole history of finance, the practical approach of the financial bubble analysis is quite new. The year 1988 was revolutionary in terms 
of behavioral finance analysis. The changes started with the fundamental work of Smith, Suchanek and Williams (SSW later in the text) in which the authors for the first time analyzed irrational bubbles in an experimental financial market. More detailed information regarding the original SSW model is provided later in the paper.

The current paper contributes to the practical analysis of behavioral finance by analyzing the impact of capital mobility on the decision-making process of investors. The theoretical background of the experiment comes from the model designed by Martin and Ventura (2010). The authors have created a model which analyzes the impact of financial friction and investor sentiment shocks on rational bubble boosts and crashes. Martin and Ventura based their work on the fundamental findings of Samuelson (1958) and Tirole (1985), known as Samuelson-Tirole model ${ }^{1}$. The authors believe that the introduction of the phenomenon of imperfect market in terms of financial friction into Samuelson-Tirole model will eliminate the factors criticized by Abel et al. $(1989)^{2}$. The initial Samuelson-Tirole model considers a frictionless market with perfect capital mobility. Martin and Ventura state that the introduction of financial friction allows both efficient and inefficient investments to co-exist. The authors have also concluded that the introduction of financial friction worsens capital mobility, which creates conditions for the appearance of bubbly episodes.

The current paper analyzes the impact of capital mobility on price behavior from a slightly different point of view than the one applied by Martin and Ventura. While the latter analyze the impact of the introduction of financial friction into the model to decrease capital mobility, the current paper analyzes the impact of the introduction of capital mobility itself into the model with

1 Tirole (1985) presents three conditions which should be met for a bubble to appear: durability, scarcity and common beliefs. The results of the analysis indicate that bubbles may crowd out potential investment by increasing the interest rate, thus increasing the cost of capital for investors. "Tirole (1985) shows that speculative bubbles can arise as rational expectations equilibria of dynamically inefficient deterministic economies, but are ruled out if dynamic efficiency prevails." (Abel et.al., 1989). Based on Diamond (1965) theory, Tirole explains the existence of financial bubbles by the surplus of capital. The capital is considered to have two aspects of its value: it can be used in production and as a store of value. According to the model, bubbles cannot exist if all the agents have identical information, as Pareto efficiency theory will not hold.

2 Abel et.al (1989) present arguments against Tirole (1985) theory. According to the authors' empirical findings, positive dividends suggest that the economy is below the Golden Rule, thus the statement of Tirole (1985) that the bubble can lead economy to the Golden Rule does not hold in reality. Abel et al. (1989) argue that the assumption that bubbles can exist only in dynamically inefficient countries does not hold in reality. 
perfect capital immobility. To get the desired market setup, the initial SSW model is modified by the introduction of the second asset (among the first papers to describe the effect of the introduction of the second asset into SSW model were Fisher and Kelly (2000), Ackert et al. (2002)) $)^{3}$ and by the possibility to lend and borrow capital. None of the presented factors is a new phenomenon; however, their combination allows for designing a unique model for assessing the impact of capital mobility on asset price dynamics in the controlled laboratory environment.

\section{Model}

The type of market applied in the current paper is based on the model designed by Smith, Suchanek and Williams in 1988. The original model is a finite-time-horizon double-auction market where traders (subjects) have a possibility to buy, sell or hold a single asset. The asset is expected to pay uncertain dividends in an amount of $0,8,28$, or 60 with equal probability of $25 \%$ at the end of each of 15 trading periods. The asset has no residual value, which basically means that after the fifteenth period the value of the asset is equal to zero. The model is based on a free market where the price of any asset is determined solely by a subject's offers either to buy or to sell.

The market model in the current paper is based on the original SSW model; however, the author has made several modifications: the introduction of the second asset and capital mobility in the form of lending/borrowing possibility. Two assets represent stocks of two companies with different life cycles. One of the assets, which has the same dividend payout characteristics as the one in the original SSW setup, is presented as stock of a young risky company,

3 Fisher and Kelly (2000) analyze the market where two assets are traded simultaneously. The model is based on SSW design, with the only difference in the number of traded assets. The authors consider different treatments which differ in asset's returns. Fisher and Kelly state that bubbles tend to appear in the prices of both assets. They also conclude that the riskier asset tends to have a higher price deviation (also stated by Ackert et al., (2002). The latter present a model similar to the one analyzed in the current paper. The authors consider two types of assets: a standard asset and a lottery-type asset, which are traded in three models. The models are constructed as follows: (i) no short-selling possibility plus borrowing, (ii) no short-selling possibility plus no borrowing and (iii) short-selling possibility with no borrowing. The (i) model with no short-selling possibility plus borrowing with two types of assets is similar to the one used in the current paper. The results of the experiment are in line with other literature related to the analysis of the experimental market with two assets which demonstrates that the lottery-type asset shows a higher deviation from the fundamental value than the standard asset. The short-selling ability decreases the deviation from the fundamental value, while the borrowing ability exerts the opposite impact on the asset price. 
while the second asset is presented as stock of a less risky mature company with a stable dividend payout policy. The idea behind the introduction of the less risky asset with a different dividend payout function is to provide subjects with an alternative for investment. Considering the recurring appearance of price bubbles in the original SSW model, the author wants to assess the subjects' rationality behind capital allocation based on two alternatives for investment. Because there are no interest payments on the cash holding, dividends are the only source of income. When the price of the risky asset increases over its fundamental value, a rational investor would rather make an investment in a capital asset (less risky asset), even if it is traded slightly above the fundamental value, than invest in a pyramid scheme asset, thus reducing inefficiency in the market. The introduction of capital mobility will allow rational investors to lend money to those who are affected by the "winner's curse", thus earning a risk-free rate of return.

Similarly to the original model, the fundamental value of both assets is based on future inflows in the form of stock dividends. The riskiness of the asset is simply the volatility of the possible dividend amount. As presented above, the dividend payout function of the first asset has a range of 60 . To reduce the riskiness of the second asset, the author has decreased the range to 6 . The possible dividend amounts are 17,20 or 23 , which also increases the probability of each to $33,(3) \%$. The dividend payout function is a common knowledge to each subject. Because dividends are determined by a random function, the outcome of which cannot be predicted, the payout amount differs from period to period; however, it is equal for all subjects within each period. The opportunity cost of investing in Stock 1 is the expected amount of dividends which can be received from the investment in Stock 2.

As previously stated, the fundamental value of the assets is based on future dividends, which are paid at the end of each trading period. Considering both: the fact that dividends are the only source of intrinsic value of an asset and the finite-horizon structure of the market, the total value of the assets at the beginning of a trading session can be calculated as a product of the amount of expected future dividends and the remaining number of periods (Formula 1). Because the dividend payout structure of both assets is based on a few possibilities (4 in case of Stock 1 and 3 in case of Stock 2) with equal probability, the average amount of the expected dividend $(A D)$ can be calculated as the arithmetic mean. The average expected dividend of Stock 1 is estimated to be 24, while the average expected dividend of Stock 2 is 20 .

$$
V=A D^{*} T
$$


The value of the assets decreases after each trading period by the dividend amount. Having this in mind, it can be concluded that the decline in the asset value is modeled by a linear function, thus can be estimated during any of the 15 periods. The current value of the stock can be calculated as a difference between the total value of the asset (all the dividends) and the amount of dividends which have already been paid out (Formula 2).

$$
V_{t}=A D^{*} T-A D^{*} T_{(t-1)}
$$

Similarly to the original SSW paper, the model applied in the current paper is subject to several limitations: the model does not assume transaction costs associated with both: the process of selling/buying the asset and making offers to sell/buy or lend/borrow; neither does it assume interest on holding money. Taking into consideration both formula (1) and formula (2), it can be concluded that stocks do not have a terminal value. As in the original SSW model, the value at the end of the last period is equal to the amount of the dividend to be paid. Subjects can have income from dividends, capital gains or a risk-free rate on lending to other subjects (the last is applicable in the second and the third trading sessions).

\section{Experiment}

\subsection{Experimental Design}

The experiment was presented to subjects as a "Stock Trading Competition" based on a market with two companies. The companies were given names and a story behind so that Stock 1 represented the stock of a young risky company, and Stock 2 represented the stock of a stable mature company. Both companies paid dividends denominated in euro. The task of each subject was to maximize his/her profit. Such a perception motivated participants to compete for recognition by others. The subject's motivation was an important driver behind decision making. The fact that subjects operated in an artificial environment with fake money impacted the decisionmaking process, thus additional motivation was presented in the form of prizes, which were given to best traders based on overall profit at the end of the session. The overall profit/loss for the whole session was calculated as the difference between the closing cash balance and the cash equivalent of the initial endowment. The actual idea of the experiment was not disclosed to the subjects. 
The experiment was conducted in April and May 2015 in the laboratory of Kozminski University, Warsaw, Poland. It consisted of three trading sessions with different applied models which are presented later in this chapter. The experiment was programmed and conducted with z-Tree (Fischbacher, 2007) experiment software.

\subsection{Participants}

The participants of the experiment were both bachelor and master students of Economy, International Business, Management in Virtual Environment, Management as well as Finance \& Accounting programs of Kozminski University. The subjects did not have relative experience of participating in/conducting similar financial laboratory experiments ${ }^{4}$; however, some subjects had experience in stock trading. The subjects were invited and selected based on an online application. The selection process was random, thus the population of each trading session differed in terms of cognitive sophistication ${ }^{5}$. Such a selection resulted in a natural division of the population into productive and unproductive investors ${ }^{6}$. The subjects could participate in one trading session only. There were 37 subjects in total, which gives 10-15 participants per trading session.

\subsection{Experimental Procedure}

Each trading session included introduction, two practice periods and fifteen trading periods. The introduction part comprised a short presentation where the coordinator described the market model. Then, every subject received a printed version of instructions with detailed information including a short description of both companies, dividend payout functions, valuation, market

4 Smith et. al. (1988) conclude that the level of subjects' experience has significant impact on the results of the experiment. The experiments with subjects with no or little experience in experimental asset markets tend to result in asset price bubbles and crashes. A similar finding is reported by Dufwenberg, Lindqvist, Moore (2003); Van Boening, Williams and LaMaster, 1993; Haruvy, Lahav and Noussair, 2007); Lei, Noussair and Plott (2001).

5 Bosch-Rosa, Meissner and Bosch-Dom (2015) analyze the importance of the impact of cognitivity of subjects on the result of the experiment. The authors conclude that the appearance of bubbles ceases when subjects have a significant level of cognitive sophistication. A random selection of the subjects in the current paper assures the diversification of the population during each trading session.

6 The assumption is based on the model presented by Martin and Ventura (2011) where productive investors are assumed to be those subjects who have a better understanding of the market, thus they are better at making investments than the others. 
rules and conditions. The subjects were given a table with the valuation based on formula (2) presented above ${ }^{7}$. Since the dividend payout function was a common knowledge and trading periods were relatively short (180 seconds), such a guide was considered to facilitate the decision-making process. The presentation was followed by a Q\&A session. The actual purpose of the experiment was not disclosed to the subjects.

The practice session consisted of two periods during which the coordinator of the experiment showed the functionality of software. The coordinator's screen was presented on a projector where he showed how to submit and accept offers, where subjects could find their stock and cash balance as well as information about the current trading period (number of the current period, number of periods left, time till the end of the period). The purpose of the practice session was to make subjects familiar with the layout of the program and its functionality. The results of the practice periods were not considered during the analysis of the experiment. The practice session was followed by a short break after which subjects traded during 15 experimental periods which lasted for 180 seconds each.

\subsection{Trading Sessions}

The whole experiment consisted of three sessions. All the sessions followed an identical stock market model: the auction-type market with two lotterytype assets. The parameters of both the assets are presented in the Model section of this paper. The level of capital mobility was the only difference between the sessions. The first session was conducted to serve as a benchmark for comparison. The applied model represented a market with perfect capital immobility. The only interaction between subjects occurred when they submitted and accepted buy and sell orders.

Capital mobility was factored in the models applied in both the second and the third sessions where, in addition to trade stocks, subjects were given a possibility to lend and borrow money among themselves. The current model does not assume any "third parties", thus all the interactions took place directly between the subjects. The lending/borrowing process was associated with a financial friction which was introduced by means of borrowing costs and collateral borrowing. The subjects could lend and borrow money among themselves at any of the 15 periods. The cost of borrowing was equal to a risk-

The valuation of Stock 1 and Stock 2 can be found in the tables presented in Appendix A and Appendix B as the "Expected Average Value" column at the end of this paper. 
free rate at the level of $4 \%$. Money could be borrowed for one trading period only. The payback process was automatized. At the end of the period, the lender's cash balance was debited with the initially lent amount plus interest, while the borrower's cash balance was credited with the same amount. As the cost of borrowing was based on the risk-free rate, the lender was guaranteed to receive his/her money back. In case the borrower did not have a sufficient cash balance to pay back, his/her cash balance turned to be negative, thus he/she was forced to sell stock at the beginning of the following period to be liquid; otherwise, he/she was considered to be a bankrupt and left the session. The market models applied in the second and the third sessions were similar, with the only difference being the process of collateralization. Stock 1 was used as a collateral for the borrowing in the second session, while Stock 2 was used as a collateral in the third session. This means that the subjects could not borrow more than the value of their holding of the stock which was used as a collateral. The current value was based on the fundamental value and calculated using Formula (2).

\section{Results and conclusions}

The obtained results show that the introduction of capital mobility has a significant impact on the inefficiency of the market. The market price deviates more over the fundamental value in the first trading session (model with perfect capital immobility) than in the following sessions where the lending/borrowing possibility is introduced. Even though the introduction of capital mobility decreases market inefficiency, the price deviation over the fundamental value can be seen in both assets during all conducted sessions. The ratio of the average price deviation over the fundamental value to the fundamental value is way higher in the first session $(56.01 \%$ and $101.33 \%$ for Stock 1 and Stock 2, respectively) than in the second (02.10\% and 19.33\%) and the third (11.10\% and $26.20 \%)$ sessions. The obtained results are in line with the findings of Martin and Ventura (2011) who have concluded that the financial friction (restrictions to capital mobility) tend to decrease market efficiency. The detailed analysis of stock price tendencies is presented in the appendixes later in the paper.

The characteristics of the occurring bubbles are commonly described in related literature. The asset's traded price tends to be lower than the fundamental value at the beginning of the session, rising in the following periods to reach the peak, and finally declines in the last trading periods. The bubble's dynamics is similar to the model presented by Minksy (1986). The 
author describes the life cycle of a bubble as a five-stage process, which is associated with the creation of the bubble, followed by the growth and the burst. The important contribution of Minksy's work is the description of an investor's behavior within each stage of the bubble's life cycle. The important statement is that prior to the point of time when the price drops, the trade volume shows a significant decrease. The same phenomenon appears during all the three conducted sessions: the number of submitted offers tends to decrease in the periods prior to the peak of the bubble.

The dynamics of price deviation over the fundamental value is similar for both stocks within each trading session, which means that the investors do not switch the investment target once they see price deviation over the fundamentals. The appearance of the price bubble in the first session of the experiment can be described by the rational expectation bubbles theory. The assumption is based on the findings of Blanchard (1979) and Blanchard and Watson (1982). The authors present the rational expectation bubbles theory in which rational bubbles exist in the market where investors are aware that the price of an asset is above its fundamental value, but they still tend to buy the asset because they believe that they will be able to sell this asset in the future for even a higher price (which was the case during the Housing Bubble of 2007). Similar conclusions were drawn by the representatives of the experimental approach of financial analysis. Smith, Suchanek and Williams were among the first to conclude that the reason for the appearance of bubbly episodes in an experimental environment lies in the subject's uncertainty about decisions of other subjects. The authors suggest that bubbles arise and expand because subjects are skeptical toward rationality of others. The finding of Lei, Noussair and Plott (2001), who based their analysis on the initial SSW model, shows that even though subjects are aware that it is impossible to resell an asset to realize a capital gain, some of them are ready to buy such an asset at a price which is higher than the fundamentals (sum of expected dividends). Such a behavior is explained by the authors as risk-loving preferences and/ or judgmental errors. Some market participants believe that even though the value of an asset is quite clear, some traders may want to acquire that asset for a higher price. It might be so even though all market participants fully understand the process of dividend distribution and have symmetric information about the market.

The overall results of the experiment are contradictive to the statement of Tirole (1985) that bubbles cannot appear in an environment of equally informed investors. Despite the fact that each subject was provided with the same information, and both asset valuation methods and dividend payout 
systems were presented to each participant, financial bubbles appeared in each trading session. The author considers the level of subjects' cognitive sophistication to play an important role in the overall results of the experiment. The difference in the price deviation of the first as opposed to the second and the third trading sessions suggests the coexistence of productive and unproductive investors in the market. The relatively smaller size of the bubble in the later sessions may be explained by the winner's curse theory. If the whole population is divided into productive and unproductive investors, an unproductive investor may bid for an asset even if the price exceeds the fundamental value, which can be caused by different reasons (lack of experience, emotions, difficulties in the estimation of fundamental value, etc.). In the meantime, a productive investor would bid for the asset as long as the price is lower than or equal to the fundamental value. Once the market price exceeds the fundamental value, the productive investor would rather stop bidding for the asset and lend his/her money to the unproductive investor who would continue the "race". The analysis of the above examples in terms of the demand and supply equilibrium will be the following: once the market price reaches the fundamental value of the asset, the productive investor would stop submitting buy orders and lend the money to the unproductive investor who would keep submitting buy orders. Even though the amount of capital being "active" in the market remains the same, the amount of active traders goes down, thus decreasing the number of submitted offers and, as a result, reducing the increase of the price.

The surprising finding is the higher price deviation of Stock 2 in comparison to the riskier (in terms of dividend payout) Stock 1. The obtained results show that even though Stock 1 tends to have a bigger high/low spread and a larger number of conducted transactions, Stock 2 seems to be more attractive for investors. Stock 2 shows a greater price deviation and a higher absolute price value during all trading sessions. This fact is quite surprising since the amount of the dividend payout of Stock 2 is lower and less volatile, thus the value of the stock can be estimated more precisely. The fact that Stock 2 exhibits a higher price deviation during both the second and the third trading sessions raises the question of the impact of collateralization.

Fostel and Geanakoplos (2008), Garleanu and Pedersen (2011) present a theoretical analysis of the reasons for the deviation from the law of one price (price discrepancy between two assets with identical or close to identical fundamental value which is based on the expected future cash flows). Despite slightly different approaches to the analysis, both papers report the same result: the asset with a collateral value tends to have higher prices than the 
assets with the same fundamental value but without a collateral value. The theoretical model divides the price of such an asset into two parts: the value attributable to the future inflows associated with the asset as well as the possibility to use it in obtaining future debt. While the first part is particularly straightforward, the author wants to concentrate on the second part. When a person needs to borrow money and can use a particular asset as a collateral, he/she would rather choose that asset, thus increase the demand. The increase of the demand, at the same time, would push up the price of the asset, thereby increasing its value as a collateral. If the supply of the asset is fixed, then even more investors may be interested in the asset since they must buy fewer items to obtain a higher collateral value, which would further increase the demand.

The important point to mention here is that the collateral value of an asset applied in the current model is based on the average expected value of future dividends, thus the fundamental value of an asset as opposed to the market value. The supply of stock is fixed in the market at the level of subjects' initial endowment. This means that both the quantity of the asset used as a collateral and its value are fixed. As a result, subjects do not have additional motivation to trade the asset at premium because this would not impact its collateral value. The second important point of why the collateral value does not have a significant impact on the price in the current paper is the dividend payout function. Stock 1 and Stock 2 cannot be considered to have identical or close to identical fundamental values.

The author suggests that more experimental sessions should be held to improve the comparability between sessions with different market models. The following factors are believed to have a significant impact on the experimental results: selection of subjects, number of subjects per session, initial endowment balance, cost of borrowing (interest rate), collateral value estimation.

Transaction costs should be introduced into the market to eliminate "noisy offers". The analysis of subject's offers shows that some traders tend to influence the market with numerous repeated offers which are unreasonably high or low. Such a behavior may bring unnecessary noise into the results of the experiment. Such an activity can be eliminated by the introduction of additional costs associated with offers, which means that the subject's cash balance would be credited with a specified amount each time he/she makes an offer. The cost of the offer should be low in order not to impact the overall results of the experiment. 


\section{Bibliography}

Abel, A.B., Mankiw, N.G., Summers, L.H. and Zeckhauser, R.J. (1989). Assessing dynamic efficiency: Theory and evidence. Review of Economic Studies, 56, 1-20.

Ackert, L.F., Charupat, N., Church, B.K. and Deaves, R. (2002). Bubbles in experimental asset markets: Irrational exuberance no more (Working Paper 2002-24), Federal Reserve Bank of Atlanta.

Blanchard, O. (1979). Speculative bubbles, crashes and rational expectations. Economics Letters, 3(4), 387-389.

Blanchard, O.J. and Watson, M.W. (1982). Bubbles, rational expectations and financial markets (NBER Working Paper No. 945).

Bosch-Rosa, C., Meissner, T. and Bosch-Domenech, A. (2015). Cognitive bubbles (working paper).

Brunnermeier, M.K. and Oehmke, M. (2012). Bubbles, financial crises, and systematic risk (working paper 18398).

Chancellor, E. (1999). Devil take the hindmost: A history of financial speculation. New York: Farrar, Straus \& Giraux.

Dufwenberg, M., Lindqvist, T. and Moore, E. (2005). Bubbles and experience: An experiment. American Economic Review, 95(5), 731-1737.

Fischbacher, U. (2007). Z-Tree: Zurich toolbox for ready-made economic experiments. Experimental Economics, 10(2), 171-178.

Fisher, E. and Kelly, F. (2000). Experimental foreign exchange markets. Pacific Economic Review, 5(3), 365-387.

Fostel, A. and Geanakoplos, J. (2008). Leverage cycles and the anxious economy. American Economic Review, 98(4), 1211-1244.

Garleanu, N. and Pedersen, L.H. (2011). Margin-based asset pricing and deviations from the law of one price. Oxford University Press.

Haruvy, E., Lahav, Y. and Noussair, Ch.N. (2007). Traders' expectations in asset markets: Experimental evidence. American Economic Review, 1902-1920.

Kindleberger, C. (2001). Manias, panics \& crashes: A history of financial crisis (4th ed.). Wiley.

Lei, V., Noussair, C.N. and Plott, C.R. (2001). Nonspeculative bubbles in experimental asset markets: Lack of common knowledge of rationality vs. actual irrationality. Econometrica, 69(4), 831-859.

Minsky, H.P. (1986). Money and crisis in Schumpeter and Keynes. In: H.J. Wagener and J.W. Drukker (eds.), The economic law of motion of modern society: A Marx-KeynesSchumpeter centennial. Cambridge: Cambridge University Press.

Samuelson, P.A. (1958). An exact consumption-loan model of interest with or without the social contrivance of money. Journal of Political Economy, 66(6), 467-482.

Smith, V., Suchanek, G. and Williams, A. (1988). Bubbles, crashes and endogenous expectations in experimental spot asset markets. Econometrica, 56, 1119-1151.

Tirole, J. (1985). Asset bubbles and overlapping generations. Econometrica, 53, 1499-1528.

Van Boening, M.V., Williams, A.W. and LaMaster, S. (1993). Price bubbles and crashes in experimental call markets. Economics Letters, 41(2), 179-85. 


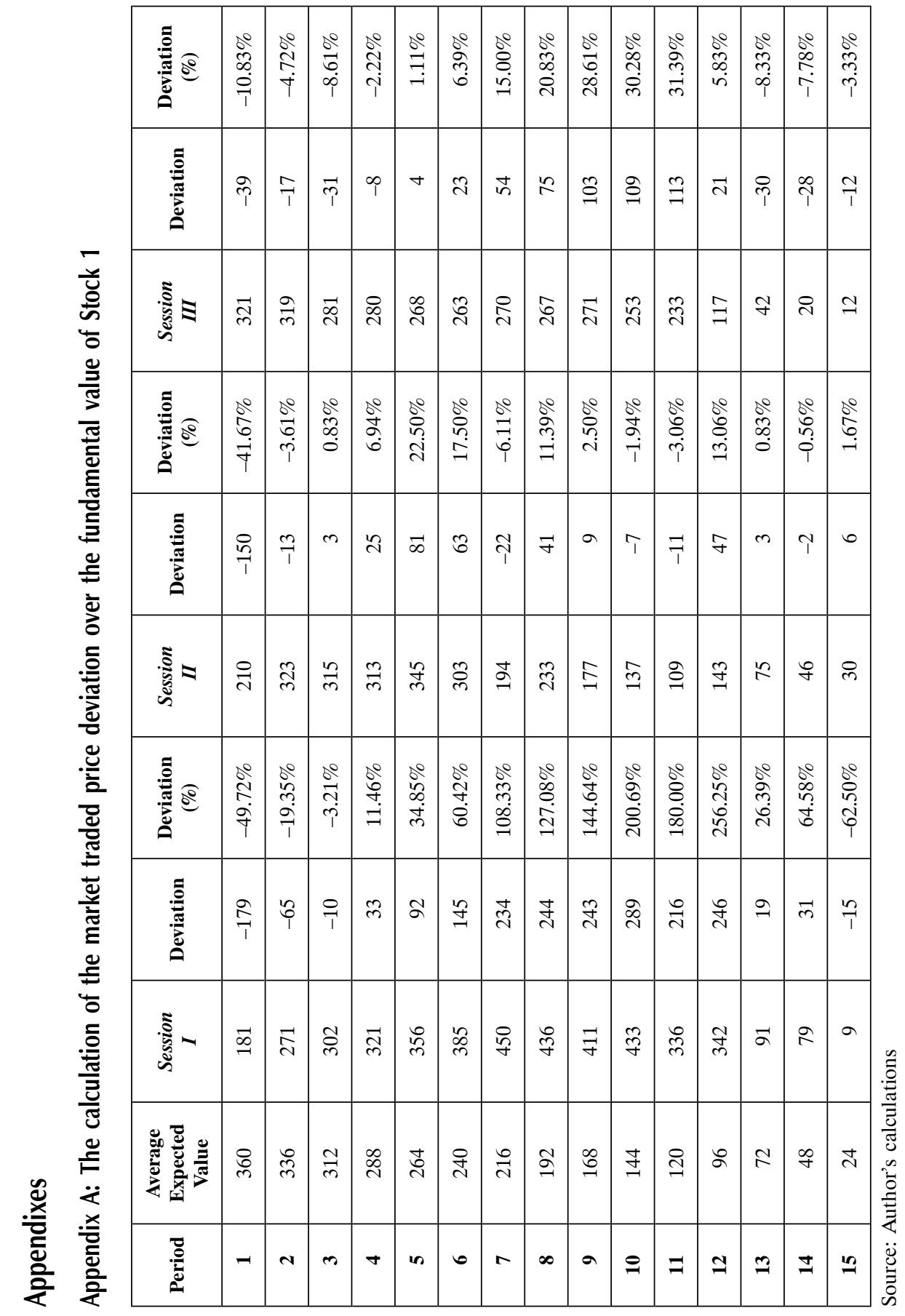




\begin{tabular}{|c|c|c|c|c|c|c|c|c|c|c|c|c|c|c|}
\hline 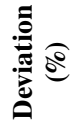 & $\begin{array}{l}\stackrel{8}{8} \\
\stackrel{8}{8} \\
\dot{p}\end{array}$ & 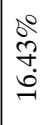 & $\begin{array}{l}\stackrel{0}{\circ} \\
\text { bे }\end{array}$ & $\begin{array}{l}\stackrel{0}{0} \\
\stackrel{0}{\circ}\end{array}$ & $\begin{array}{l}\stackrel{0}{0} \\
8 \\
\stackrel{0}{0}\end{array}$ & $\begin{array}{l}\stackrel{8}{\circ} \\
\stackrel{n}{n} \\
\stackrel{n}{N}\end{array}$ & 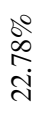 & 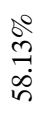 & $\begin{array}{l}\stackrel{0}{\circ} \\
\stackrel{i}{i}\end{array}$ & $\begin{array}{l}\stackrel{\circ}{\perp} \\
\stackrel{+}{\infty}\end{array}$ & 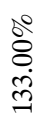 & 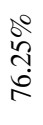 & $\begin{array}{l}\delta^{0} \\
m \\
m \\
\infty \\
\infty\end{array}$ & 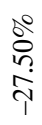 \\
\hline فี & $\frac{1}{1}$ & fo & $\check{\sim}$ & $\beth$ & 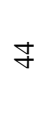 & $q$ & $F$ & $\sigma$ & $\stackrel{1}{\circ}$ & 음 & 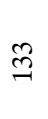 & 5 & $\hat{p}$ & $\overline{7}$ \\
\hline
\end{tabular}

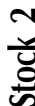

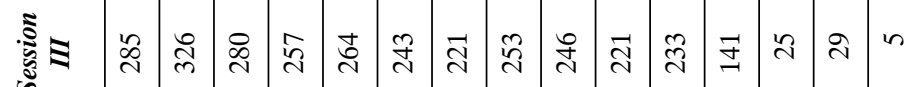

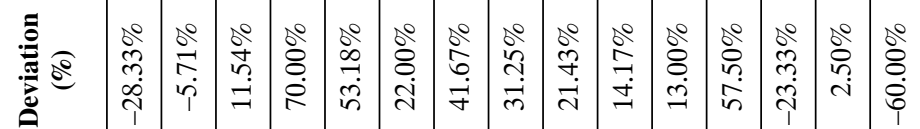

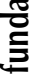
$\stackrel{Ð}{=}$

ปั 는

$\frac{2}{\Phi}$

离

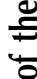

흘 흘

$\stackrel{巳}{Е}$

$\ddot{\theta}$

$\frac{. x}{\frac{x}{0}}$

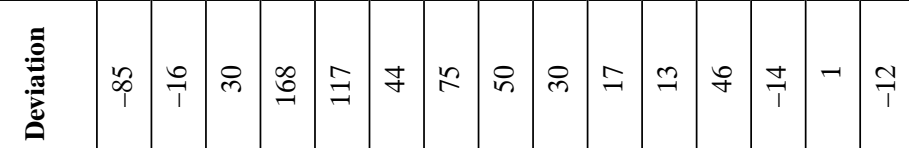

$$
\begin{aligned}
& \text { 㲵 }
\end{aligned}
$$

\begin{tabular}{|c|c|c|c|c|c|c|c|c|c|c|c|c|c|c|c|}
\hline . & $\overrightarrow{\mathcal{I}}$ & $\stackrel{2}{2}$ & I & $\cong$ & $\widehat{\sigma}$ & $\stackrel{\text { I }}{q}$ & $\tilde{\delta}$ & ల్లి & 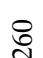 & $\stackrel{8}{1}$ & ț & $\stackrel{\text { I }}{\sim}$ & 8 & in & $\infty$ \\
\hline
\end{tabular}$$
\begin{array}{ll|l|l|l|l|l|l|l|l|l|l|l|l|l}
\hline & & & & & & & & & & & & & & \\
\hline
\end{array}
$$

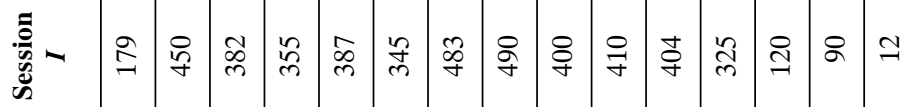

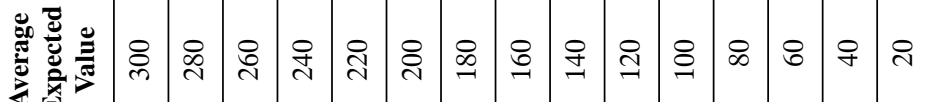

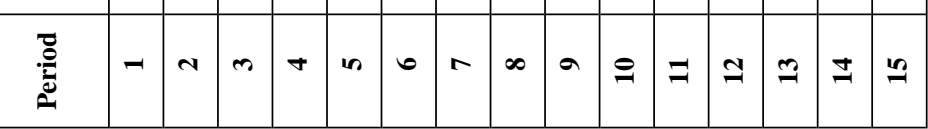

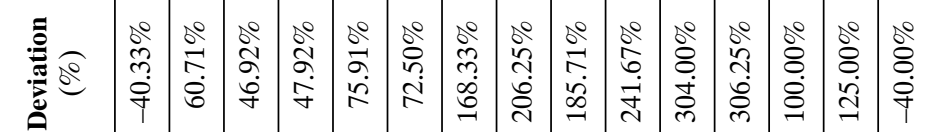

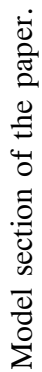
$\begin{array}{ll} & \\ 0 \\ 0 \\ 0 \\ 0 \\ 0 \\ 0 \\ 0 \\ 0 \\ 0 \\ 0 \\ 0 \\ 0 \\ 0 \\ 0 \\ 0 \\ 0\end{array}$

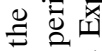
$\Xi \bar{\circlearrowright}$

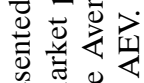

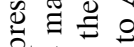

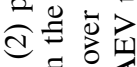
$\because \because 8<$

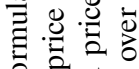
오명 ธี 胥 푱 范 马ु 苀

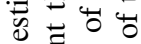
园造造 这氖

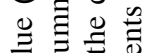

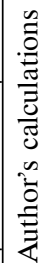
$>80$ 을

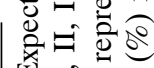
讷

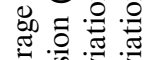

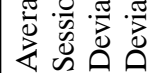



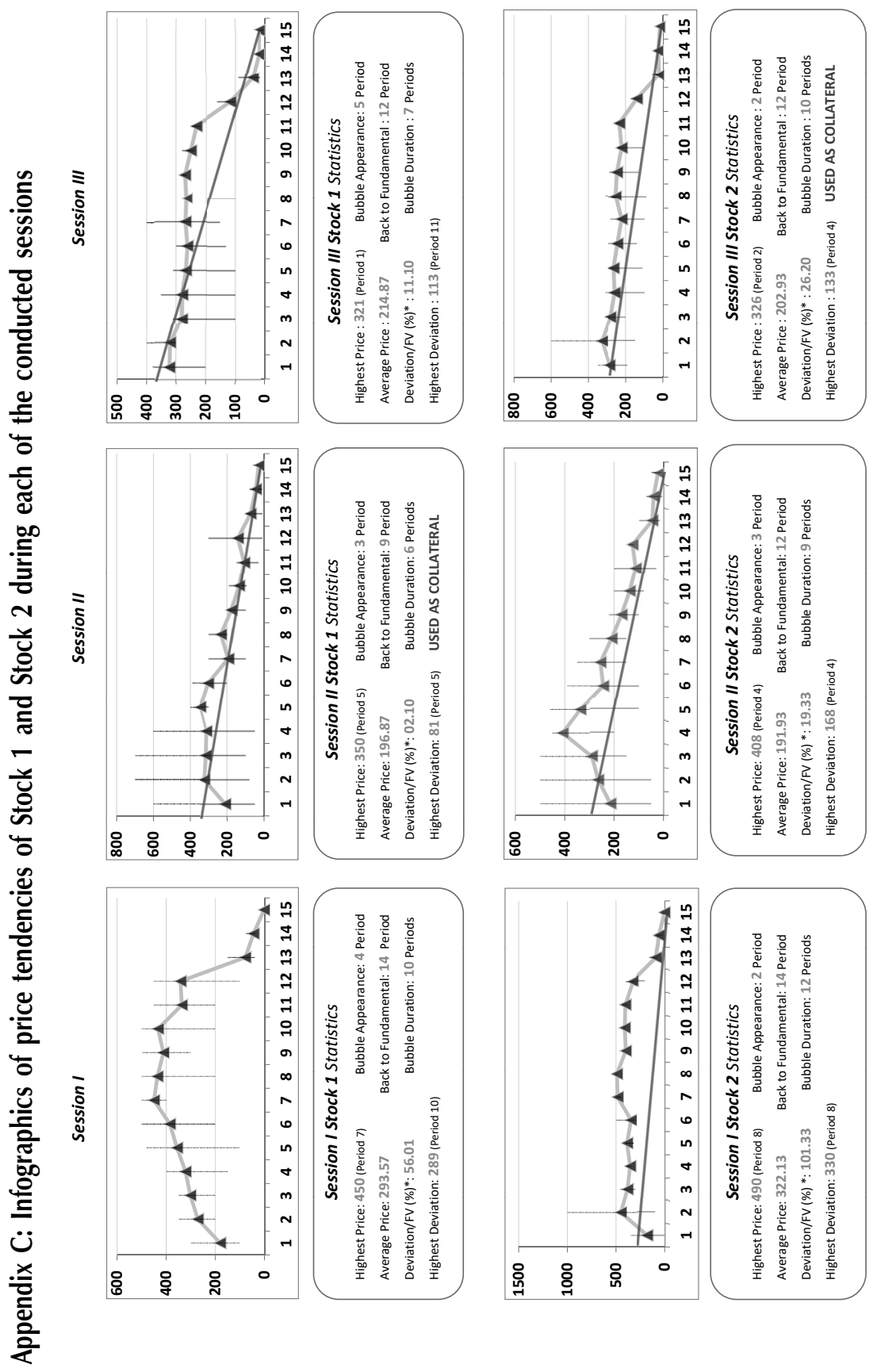

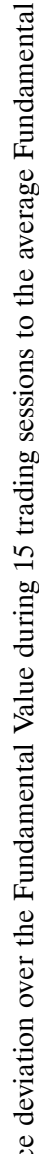
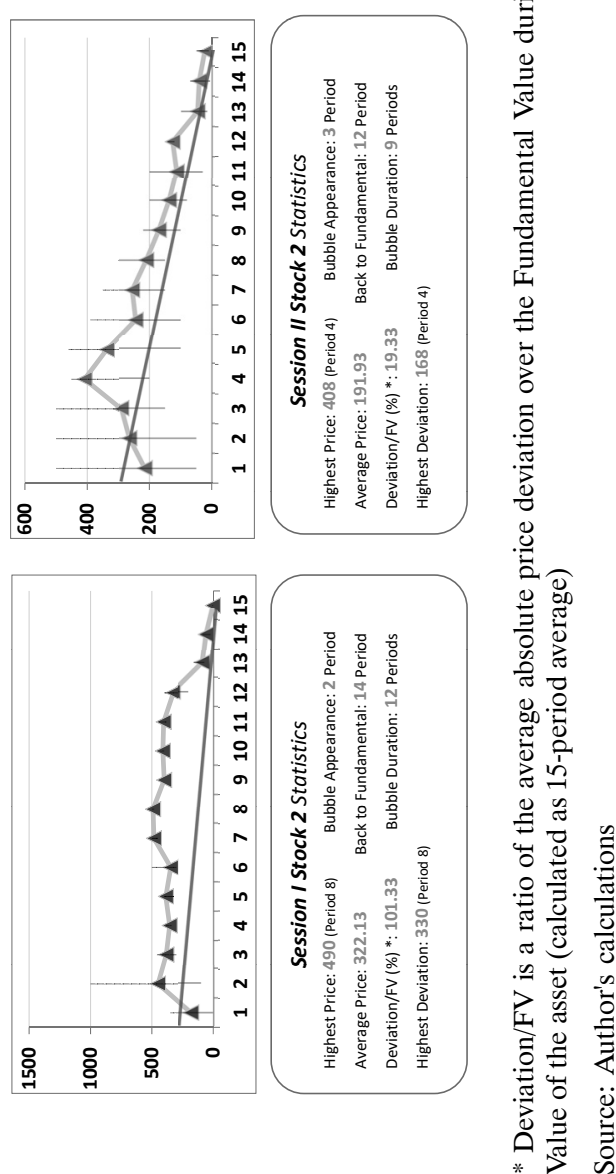
